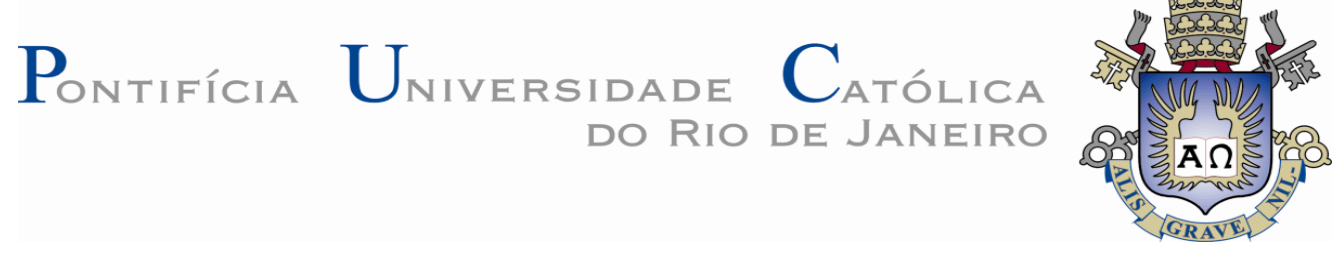

Mônica Santana Vianna

Desenvolvimento de biosensor multiparâmetros para neurotoxinas em amostras clínicas e ambientais

Tese de Doutorado

Tese apresentada como requisito parcial para obtenção do título de Doutor em Ciências - Química pelo Programa de Pós-Graduação em Química, do Departamento de Química da PUC-Rio.

Orientador: Ricardo Queiroz Aucélio Co-orientador: Roberta Lourenço Ziolli

Rio de Janeiro setembro de 2012 


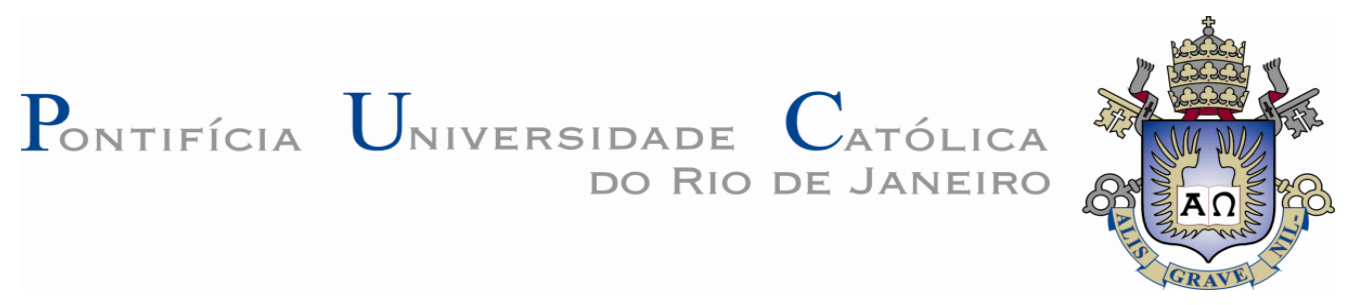

Mônica Santana Vianna

\section{Desenvolvimento de biosensor multiparâmetros para neurotoxinas em amostras clínicas e ambientais}

Tese apresentada como requisito parcial para obtenção do grau de Doutor em Ciências - Química pelo Programa de Pós-Graduação em Química, do Departamento de Química da PUC-Rio. Aprovada pela Comissão Examinadora abaixo assinada:

Prof. Ricardo Queiroz Aucélio Orientador Departamento de Química - PUC-Rio

Prof $^{a}$. Roberta Lourenço Ziolli Co-orientadora Depto.de Ciências Naturais - UNIRIO

Profa. Andrea Medeiros Salgado Escola de Química -UFRJ

Profa. Claudia Nascimento Depto.de Ciências Naturais - UNIRIO

Prof. Edwin Gonzalo Azero Rojas Depto.de Ciências Naturais - UNIRIO

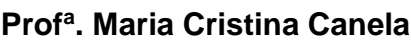
Centro de Ciências Exatas e Tecnologia - UENF

Profa. Sônia Renaux Wanderley Louro Departamento de Física - PUC-Rio

Prof. José Eugenio Leal Coordenador Setorial do Centro Técnico Científico - PUC-Rio 
Todos os direitos reservados. É proibida a reprodução total ou parcial do trabalho sem autorização da universidade, da autora e do orientador.

\section{Mônica Santana Vianna}

Graduou-se em Ciências Biológicas na UFRJ em 1999. Trabalhou na PESAGRO-RIO durante os anos de 2002 a 2006. Possui mestrado em Química Analítica pela Pontifícia Universidade Católica do Rio de janeiro (2008).

Ficha Catalográfica

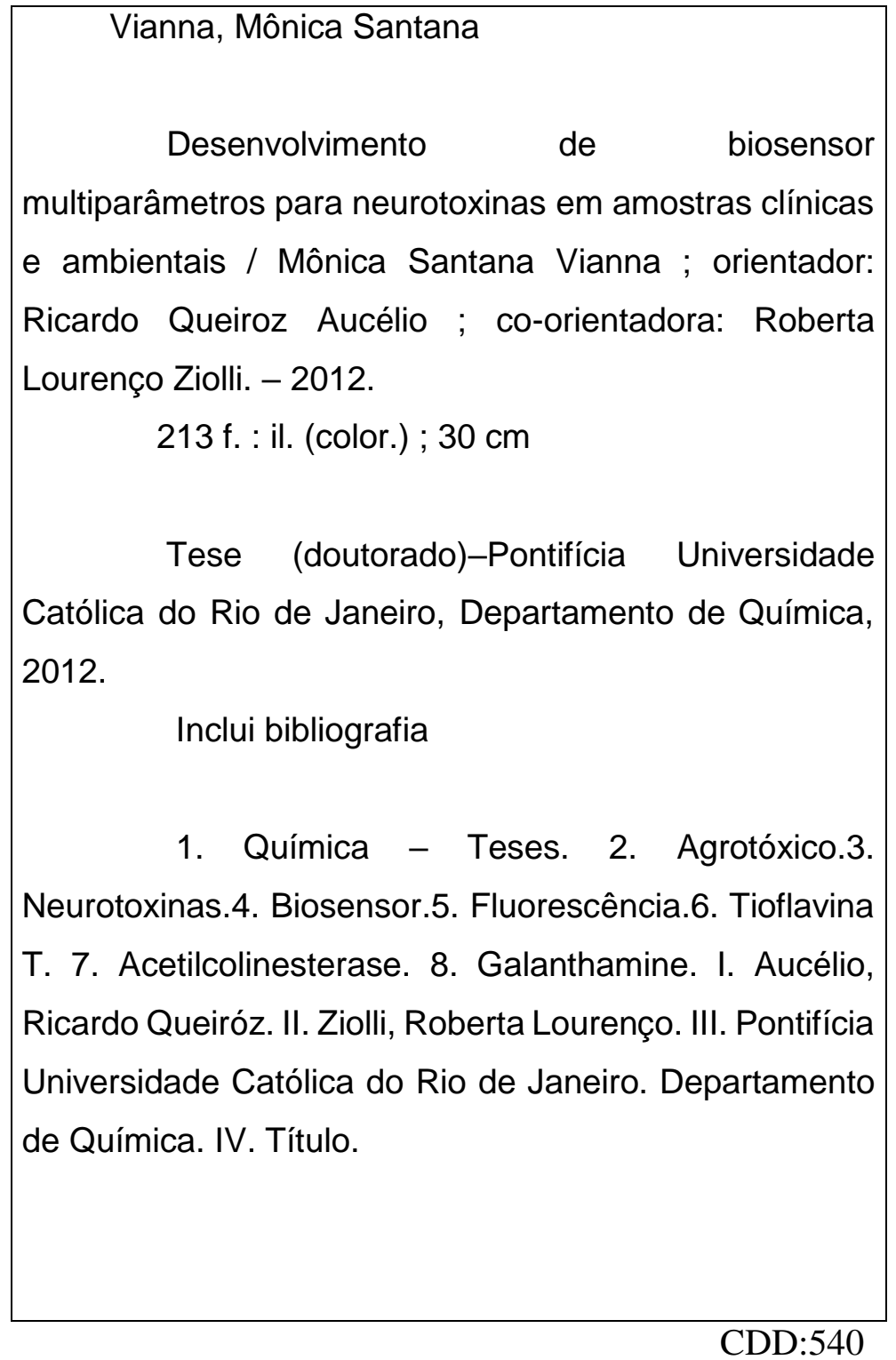


Dedico a meu pai Rubens e meu marido Josiel, razão de todas as minhas realizações. 


\section{Agradecimentos}

Ao meu pai e meu marido pelo grande apoio e por toda a compreensão ao longo do meu trabalho.

À professora Roberta Lourenço Ziolli pelo apoio e confiança durante esses anos de trabalho e orientação,cumprindo seu papel de educadora zelando pela a minha formação plena.

Ao professor Ricardo Aucélio que não se limitou em ser orientador,ao me receber em seu laboratório, mas que também soube apoiar minhas idéias. Sua generosidade foi meu incentivo para passar pelas dificuldades.

Ao meu grande amigo Sarzamin Khan que tornou possível a conclusão desta tese através do seu apoio imprescindível e inesquecível.

Aos amigos do LEEA Paulo, Júnior, Leila. Adriana e Sônia que me acolheram com carinho.

Aos amigos do LEEA e companheiros nessa jornada: Cabrini, Ana Paula, Catalina, Alex por compartilhar momentos importantes deste caminho.

Aos professores e funcionários do departamento de Química da PUC pela ajuda e excelente serviço.

Ao $C N P q$ e à PUC-Rio, pelos auxílios concedidos e por ter possibilitado esta pesquisa.

O presente trabalho foi realizado com apoio da Coordenação de Aperfeiçoamento de Pessoal de Nível Superior - Brasil (CAPES) - Código de Financiamento 001. 


\section{Resumo}

Vianna, Mônica Santana; Aucélio, Ricardo Queiroz. Desenvolvimento de biosensor multiparâmetros para análise de neurotoxinas em amostras clínicas e ambientais. Rio de Janeiro, 2012. 213p. Tese de Doutorado Departamento de Química, Pontifícia Universidade Católica do Rio de Janeiro.

O destino e os efeitos de produtos farmacêuticos recentemente se tornou uma questão de interesse ambiental embora pouco seja conhecido sobre sua entrada no ambiente. As drogas colinérgicas e colinesterásicas apresentam-se como um alvo importante da pesquisa ambiental relacionado a sua entrada no ambiente e suas interações físico-químicas e biológicas. Os ensaios com uso de à sondas protéicas são empregados para identificar a formação de complexos na presença de grupos específicos ou indicam a concentração de ligantes presente no ambiente onde se encontra a proteína. O emprego da enzima acetilcolinesterase (AChE) em biosensores para deterninação de inibidores é frequente porém poucos trabalhos exploram a fluorescência intrínseca das enzimas no desenvolvimento de metodologias para detectar espécies químicas ligantes. O objetivo deste trabalho foi propor novas sondas fluorescentes e formas de bioreconhecimento para a determinação de neurotoxinas em diferentes amostras. A proposta foi a de identificar sondas eficientes, de fácil obtenção e baixo custo para o desenvolvimento de métodos simples, sensíveis e seletivos. Para isso a detecção foi baseada na variação da fluorescência intrínseca das proteínas(por sua interação específica com os analitos) e na conjugação de fluoróforos extrínsecos específicos. Pode-se comprovar experimentalmente que a fração protéica obtida pode ser utilizada como sonda fluorescente na determinação dos analitos apresentados neste estudo. Nas determinações dos cinco analitos, os valores de LD e de LQ foram satisfatórios para a aplicação do método em amostras ambientais (solo) e clínicas (urina).As determinações de Gal apresentou desempenho satisfatório para atender diferentes tipos de amostras $\left(\mathrm{LD}=1,3 \times 10^{-}\right.$ $\left.{ }^{9} \mathrm{~mol} \mathrm{~L}{ }^{-1} \mathrm{e} \mathrm{LQ}=2,1 \times 10^{-8} \mathrm{~mol} \mathrm{~L}^{-1}\right)$. Os valores de LD e LQ para atropina $\left(9,7 \times 10^{-}\right.$ ${ }^{10} \mathrm{~mol} \mathrm{~L}^{-1} \mathrm{e} 2,4 \times 10^{-8} \mathrm{~mol} \mathrm{~L}^{-1}$, respectivamente) mostram-se adequados visto que outros sensores, como os eletroquimioluminescentes, apresentaram um valor de LQ de $1 \times 10^{-7} \mathrm{~mol} \mathrm{~L}^{-1} \mathrm{em}$ amostras de urina. O método para os agrotóxicos metomil ( $\mathrm{LD}=9,5 \times 10^{-10} \mathrm{~mol} \mathrm{~L}^{-1}$ e $\left.\mathrm{LQ}=2,2 \times 10^{-8} \mathrm{~mol} \mathrm{~L}^{-1}\right)$; metamidofós 
$\left(\mathrm{LD}=1,5 \times 10^{-9} \mathrm{~mol} \mathrm{~L}^{-1}\right.$ e $\left.\mathrm{LQ}=3,8 \times 10^{-8} \mathrm{~mol} \mathrm{~L}^{-1}\right)$ e metil paration $\left(\mathrm{LD}=9,7 \times 10^{-}\right.$ ${ }^{10} \mathrm{~mol} \mathrm{~L}^{-1} \mathrm{e} \mathrm{LQ}=1,8 \times 10^{-7} \mathrm{~mol} \mathrm{~L}^{-1}$ ) apresentarambom desempenho comparandose à outros métodos descritos na literatura. A aplicação do método proposto em amostras de solo e urina (sem pré-tratamento) obtiveram recuperações a partir de $88 \%$ (agrotóxicos em solo) e dos cinco analitos em urina. O método por fluorescência da sonda protéica não obteve diferença significativa do método analítico dos analitos por HPLC. A adaptação do método proposto à um sistema de biosensor com uso de uma sonda extrínseca (Tioflavina T) foi avaliado positivamente permitindo a imobilização da fração protéica em microplaca e o uso da Tioflavina T como sonda fluorescente da ligação AChE-inibidores.

\section{Palavras-chave}

Agrotóxico; neurotoxinas; biosensor; fluorescência; acetilcolinesterase tioflavina $\mathrm{T}$; galantamina. 


\section{Abstract}

Vianna, Mônica Santana; Aucélio, Ricardo Queiroz (Advisor). Development of Multiparameter Biosensor for Analysis of Neurotoxins in Clinical and Environmental Samples. Rio de Janeiro, 2012. 213p.Dsc Thesis-Departamento de Química, Pontifícia Universidade Católica do Rio de Janeiro.

The fate and effects of pharmaceutical products has recently become a matter of environmental concern although little is known about its entry into the environment. Therefore, the cholinergic and cholinesterasicpresent a major target of environmental research related to his entry into the environment and their physico-chemical and biological interactions. Tests using the protein compounds as probes are employed where the optical properties of the complex protein-signal in the presence of analyte or specific groups indicating the concentration of ligand present in the environment. The use of acetylcholinesterase (AChE) activity in biosensors for inhibitors determination is common but few studies explore the intrinsic fluorescence of enzymes in the development of methods to detect chemical species ligands. The objective of this study was to propose new forms of fluorescent probes and bioaffinity for the determination of neurotoxins in different samples. The proposal was to identify probes efficient, easily accessible and low cost for the development of simple, sensitive and selective. For this the detection was based on the variation of the intrinsic fluorescence of proteins (by its specific interaction with the analytes) and the specific combination of extrinsic fluorophores. For the results presented in this plan can be affirmed that the protein fraction obtained can be used as a fluorescent probe in the determination of analytes of this study.Based on the five determinations of analyte, the values of LD and LQ are satisfactory for applying the method in environmental samples (ground) and clinical (urine). Measurements of Gal showed satisfactory performance to suit different types of samples $\left(\mathrm{LD}=1.3 \times 10^{-9} \mathrm{~mol} \mathrm{~L} \mathrm{~L}^{-1} \mathrm{eLQ}=2.1\right.$ x $\left.10^{-8} \mathrm{~mol} \mathrm{~L}^{-1}\right)$ values and LD LQ to atropine $\left(9.7 \times 10^{-10} \mathrm{~mol} \mathrm{~L}^{-1}\right.$ and $2.4 \times 10^{-8}$ mol $\mathrm{L}^{-1}$, respectively) appear to be suitable as other sensors, such as eletroquimioluminescentes showed a value of $1 \mathrm{LQ} \times 10^{-7} \mathrm{~mol} \mathrm{~L}^{-1}$ in urine samples. The method for pesticide methomyl $\left(\mathrm{LD}=9.5 \times 10^{-10} \mathrm{~mol} \mathrm{~L}-1\right.$ and $\mathrm{LQ}=$ $\left.2.2 \times 10^{-8} \mathrm{~mol} \mathrm{~L}^{-1}\right)$, methamidophos ( $\mathrm{LD}=1.5 \times 10^{-9} \mathrm{~mol} \mathrm{~L}^{-1}$ and $\mathrm{LQ}=3.8 \times 10^{-8}$ mol $\left.\mathrm{L}^{-1}\right)$ and methyl parathion $\left(\mathrm{LD}=9.7 \times 10-10 \mathrm{~mol} \mathrm{~L}^{-1}\right.$ and $\mathrm{LQ}=1.8 \times 10^{-7} \mathrm{~mol}$ 
$\mathrm{L}^{-1}$ ) comparing presents betterperformance to the other methods described in literature. The method proposed in soil samples and urine (no pretreatment) had recovered from $88 \%$ (ground pesticides) and five of analytes in urine. The t test comparison of means, applied to sets of determinations by fluorescence probe method and HPLC indicated the statistical equality in both recoveries. The adaptation of the proposed method a system of the biosensor with the use of an extrinsic probe (thioflavin $\mathrm{T}$ ) has positively evaluated allowing immobilization of the protein in microplates and the use of thioflavin $\mathrm{T}$ as a fluorescent probeconnecting AChE inhibitors.

\section{Keywords}

Pesticide; neurotoxins; biosensor; acetylcholinesterase; fluorescence; thiflavin T; galanthamine 


\section{Sumário}

INTRODUÇÃO 26

1.1. Neurotoxinas 26

1.1.1. Neurotoxinas e exposição humana 26

1.1.2. Agrotóxicos $\quad 27$

1.1.2.1. Metilcarbamatos 30

1.1.2.2. Organofosforados 32

1.1.3. Fármacos residuais 36

1.1.3.1. Fármacos colinérgicos e anticolinesterásicos 38

1.2. MÉTODOS ANALÍTICOS 43

1.2.1. Metomil 44

1.2.2. Galantamina 48

1.2.3. Atropina 49

1.3. FLUORESCÊNCIA DE PROTEÍNAS 51

1.3.1. Aplicações da fluorescência no estudo de proteínas 52

1.4. A aplicação da AChE como sonda 54

1.4.1. Sonda fluorescente extrínseca aplicada ao estudo da AChE 60

2 OBJETIVOS E JUSTIFICATIVA 64

2.1. Objetivos 64

$\begin{array}{ll}\text { 2.2. Justificativa } & 65\end{array}$

3 PARTE EXPERIMENTAL 66

3.1. Instrumentação 66

$\begin{array}{ll}\text { 3.2. Reagentes } & 67\end{array}$

$\begin{array}{ll}\text { 3.3. Procedimentos } & 67\end{array}$

3.3.1. Preparação da Fração enzimática de AChE

$\begin{array}{ll}\text { a partir de cérebro de rato } & 67\end{array}$

3.3.2. Otimização das condições de medição:

planejamento experimental $\quad 69$

3.3.3. Parâmetros cineticos e inibição da atividade catalítica da AChE 71 
3.3.4. Estudos espectroscópicos preliminares: efeito filtro interno

3.3.5. Medição de supressão de fluorescência 72

3.3.6. Estudo do desempenho do biossensor em microplacas 73

3.3.7. Coleta e tratamento das amostras de solo 75

3.3.7.1. Coleta 75

3.3.7.2. Caracterização do Solo 76

3.3.7.3. Fortificação e extração 76

3.3.8. Validação 76

3.3.8.1. Determinações por fluorescência e cromatografia líquida 76

3.3.8.2. Parâmetros de desempenho analítico 77

4 RESULTADOS $\quad 80$

4.1. Preparação da Fração protéica a partir de cérebro de rato 80

4.1.1. Caracterização cinética 82

4.2. Otimização das condições de complexação:

planejamento experimental 83

4.2.1. Fração protéica (controles) 84

4.2.1.1. Fluorescência 84

4.2.1.2. Cinética 88

4.2.2. Fração protéica e resposta na presença dos analitos 91

4.2.2.1. Galantamina (GAL) 92

4.2.2.2. Atropina 96

$\begin{array}{ll}\text { 4.2.2.3. Metomil } & 101\end{array}$

4.2.2.4. Metamidofós 107

4.2.2.5. Metil paration 111

4.2.2.6. Acefato 115

4.2.3. Aplicação da otimização com restrição 115

4.2.3.1. Fluorescência 116

4.2.3.2. Cinética 118

4.2.4. Conclusão sobre os planejamentos 118

4.3. Estudo espectroscópico das interações 119

4.3.1. Estudos espectroscópicos preliminares: efeito filtro interno 120

4.3.2. Mecanismos de Supressão 123 
4.3.2.1. Atropina 125

4.3.2.2. Galantamina 129

4.3.2.3. Metomil 134

$\begin{array}{ll}\text { 4.3.2.4. Metamidofós } & 137\end{array}$

4.4. Aplicação da tioflavina T 141

4.5. Validação dos métodos 155

4.5.1. Estudo de seletividade 163

4.5.2. Aplicação em amostras clínicas e ambientais 166

4.5.2.1. Urina 166

$\begin{array}{ll}\text { 4.5.2.2. Solo } & 171\end{array}$

5 CONCLUSÃO 177

6 REFERÊNCIAS BIBLIOGRÁFICAS 179 


\section{Lista de figuras}

Figura 1 - Fórmula molecular do metil-carbamato metomil

Figura 2 - Fórmula estrutural de alguns organofosforados e carbamatos.

Figura 3 - Representação esquemática dos mecanismos de ação dos fármacos colinérgicos e colinesterásicos sobre os receptores de membrana e sobre a enzima acetilcolinesterase.

Figura 4 - Fórmula estrutural da galantamina.

Figura 6 - Degradação da acetilcolina promovida pela ação catalítica da acetilcolinesterase.

Figura 7- Fórmula estrutural da tioflavina $T$

Figura 8 - Vista dorsal do cérebro de rato durante sua dissecção.

Figura 9- Esquema representativo do planejamento composto central: 8 pontos fatoriais em 2 níveis $+2 n$ ( $2 \times 3=6$ pontos axiais) +4 (pontos centrais com 3 replicatas).

Figura 10 - Foto da microplaca com as incubações enzimáticas com adição de substrato e reativo de cor.

Figura 11- Gráfico de Pareto indicando os efeitos estatisticamente significativos para o desenho experimental aplicado mostrando a importância dos 3 fatores escolhidos para o estudo

Figura 12: Representação gráfica do modelo de regressão gerado a partir do desenho experimental. Identifica-se o ponto crítico (ponto de mínimo) no valor de 236,85. u.a.

Figura 13 - Gráfico de Pareto indicando as 3 variáveis significativas e seus efeitos principais. 
Figura 14 - Gráfico mostrando a correlação entre o modelo e os valores experimentais de fluorescência.

Figura 15 - Superfície de resposta com a cinética da AChE (expressa por atividade aparente/min). Ponto de sela: 0,108 de atividade aparente/min

Figura 16 - Gráfico de Pareto identificando os fatores principais e as interações e suas significâncias estatísticas.

Figura 17 - Gráfico mostrando a correlação entre o esperado pelo modelo e os valores experimentais.

Figura 18 - Apresentação gráfica do modelo de regressão (superfície de reposta). Ponto de mínimo: 316,59.

Figura 19 - Gráfico de Pareto indicando a ausência de influência dos três parâmetros na atividade enzimática da AChE.

Figura 20 - Gráfico de Pareto identificando os fatores e suas interações no sistema incubado com atropina $\left(10 \mathrm{\mu gL}^{-1}\right)$.

Figura 21 - Gráfico mostrando a correlação entre os valores previstos e observados. Para os menores valores de intensidade de sinal (próximo à $300-350$ u.a).

Figura 22 - Superfície de resposta do modelo de regressão obtido para o sinal de fluorescência da fração protéica na presença de 10 $\mu \mathrm{gL}^{-1}$ de atropina. Ponto de mínimo em 341,66 u.a.

Figura 23 - Gráfico de Pareto para a atividade específica da AChE presente na fração protéica na presença de $62,25{\mu \mathrm{gL}^{-1}}^{-1 e}$ atropina.

Figura 24 - Gráfico de superfície de resposta para a atividade aparente da AChE após incubação com 62,25 $\mathrm{gLL}^{-1}$ de atropina. Figura 25 - Gráfico de Pareto mostrando os valores dos efeitos para a intensidade do sinal de fluorescência da fração protéica.

Figura 26 - Gráfico de resíduos (comportamento do sinal de fluorescênci total da fração protéica) após a incubação com $5 \mu \mathrm{gL}-$ 1 de metomil. 
Figura 27 - Superfície de resposta do modelo após incubação co $\mu \mathrm{gL}^{-1}$ de metomil. Ponto de sela de 338,77 u.a.

Figura 28 - Gráfico dos valores dos coeficientes dos efeitos sobre a atividade aparente da AChE.

Figura 29 - Gráfico indicando o ajuste do modelo linear previsto cuja distribuição dos resíduos é aleatória.

Figura 30 - Representação gráfica do modelo de regressão linear da atividade enzimática aparente da AChE tempo de 30 minutos de incubação do sistema.

Figura 31 - Gráfico de Pareto indicando os coeficientes dos efeitos das variaveis e suas interações.

Figura 32 - Gráfico mostrando a distribuição aleatória dos resíduos, indicando a adequação do modelo proposto pelo planejamento.

Figura 33 - Representação gráfica do modelo quadrático gerado para a resposta de fluorescência da fração protéica na presença de $40 \mu \mathrm{gL}^{-1}$ metamidofós. Ponto de mínimo: 295 u.a.

Figura 34 - Gráfico de Pareto mostrando os coeficientes do efeitos do modelo linear para a atividade da AChE na presença de metamidofós.

Figura 35 - Representaçãodo modelo linear que relaciona as variáveis independentes com a atividade enzimática da AChE após 100 minutos de incubação.

Figura 36 - Gráfico de pareto indicando a influência das variáveis sobre a atividade aparente da AChE após incubação com $20 \mu \mathrm{g} \mathrm{L}-$ 1 de metil paration.

Figura 37 - Superfície de resposta do modelo de regressão linear para a atividade enzimática da AChE após 60 minutos de incubação na presença de $20 \mu \mathrm{g} \mathrm{L}^{-1}$ de metil paration.

Figura 38 - Gráfico dos resíduos (valores previstos $\mathrm{x}$ resíduos) indicando o ajuste do modelo linear proposto.

Figura 39 - Representação da sobreposição dos modelos gerados pelos planejamentos gerada pela função "desejabilidade". 
Figura 40 - Gráfico com os valores previstos pelo modelo de regressão para a intensidade de fluorescência de proteína total na presença dos analitos metomil, galantamina e atropina e seus controles.

Figura 41 - Espectro de absorvância da AChE (Electrophorus electricus) e da fração proteíca (cérebro de rato) na concentração de $0,06 \mathrm{mg} \mathrm{mL}^{-1}$.

Figura 42 - Espectro de absorção de soluções dos analitos galantamina $\left(2 \times 10^{-7} \mathrm{~mol} \mathrm{~L}^{-1}\right)$ e atropina $\left(2 \times 10^{-7} \mathrm{~mol} \mathrm{~L}^{-1}\right)$.

Figura 43 - Espectro de absorvância da solução de $\left(3 \times 10^{-7} \mathrm{~mol} \mathrm{~L}^{-1}\right)$ de metamidofós.

Figura 44 - Espectro de emissão de fluorescência da AChE purificada após titulação com atropina até o ponto de saturação.

Figura 45 - Espectro de fluorescência das proteínas totais da fração

de cérebro de rato durante titulação com atropina $\left(2 \times 10^{-8}\right.$ à $1,4 \times$ $\left.10^{-7} \mathrm{molL}^{-1}\right)$.

Figura 46 - Curvas de supressão de fluorescência da fração protéica do extrato de cérebro e da AChE purificada.

Figura 47 - Gráfico de Stern-Volmer mostrando a diferença na afinidade de formação de complexos com a atropina em duas temperatura $\left(27^{\circ} \mathrm{C}\right.$ e $\left.30^{\circ} \mathrm{C}\right)$

Figura 48- Gráfico log-log da supressão da fluorescência da AChE purificada em titulação com atropina $\left(2 \times 10^{-8}\right.$ à $\left.1,4 \times 10^{-7} \mathrm{~mol} \mathrm{~L}^{-1}\right)$.

Figura 49 - Espectro de emissão de fluorescência da AChE purificada após titulação com 1,7 x 10-8 $\mathrm{mol} \mathrm{L}^{-1}$.

Figura 50 - Espectro da fração protéica titulada com galantamina na faixa de $1,7 \times 10^{-8}$ à $1,2 \times 10^{-7} \mathrm{~mol} \mathrm{~L}^{-1}$

Figura 51 - Curva de supressão de fluorescência da fração protéica em titulação com galantamina $\left(1,7 \times 10^{-8}\right.$ à $1,0 \times 10^{-7} \mathrm{~mol}$ $\left.\mathrm{L}^{-1}\right)$.

Figura 52 - Curva de supressão de fluorescência da fração 
protéica em 4 temperaturas $\left(24^{\circ} \mathrm{C}, 27^{\circ} \mathrm{C}, 30^{\circ} \mathrm{C}\right.$ e $\left.34^{\circ} \mathrm{C}\right)$.

Figura 53 - Gráfico de log-log da curva de supressão da fração protéica pela Galantamina $\left(1,1 \times 10^{-8}\right.$ à $\left.1,0 \times 10^{-7} \mathrm{~mol} \mathrm{~L}^{-1}\right)$

Figura 54 - Espectro da AChE purificada antes e após adição de $\left[2,5 \times 10^{-8} \mathrm{~mol} \mathrm{~L}^{-1}\right]$ de metomil e $\left[2,5 \times 10^{-8} \mathrm{~mol} \mathrm{~L}^{-1}\right]$ de metamidofós (organofosforado)

Figura 55 - Espectro da fração de cérebro de rato durante titulação com metomil $\left(2,5 \times 10^{-8}\right.$ à $\left.1,2 \times 10^{-7} \mathrm{~mol} \mathrm{~L}^{-1}\right)$.

Figura 56 - Curva de supressão de fluorescência da fração protéica durante titulação com metomil $\left(2,5 \times 10^{-8}\right.$ à $\left.1,2 \times 10^{-7} \mathrm{~mol} \mathrm{~L}^{-1}\right)$.

Figura 57 - Gráfico de log-log da curva de supressão da fração protéica por metomil.

Figura 58 - Espectro de fluorescência da fração de cérebro de rato durante titulação com $\left(3,5 \times 10^{-8}\right.$ à $\left.2,5 \times 10^{-7} \mathrm{~mol} \mathrm{~L}^{-1}\right)$ de metamidofós.

Figura 59 - Curva de supressão da fluorescência da fração protéica de cérebro por metamidofós ( $3,5 \times 10^{-8}$ à $\left.2,5 \times 10^{-7} \mathrm{~mol} \mathrm{~L}^{-1}\right)$.

Figura 60- Curva de supressão de fluorescência do extrato em duas temperaturas $\left(24\right.$ e $\left.34^{\circ} \mathrm{C}\right)$.

Figura 61- Gráfico do duplo-log da supressão de fluorescência do extrato por metamidofós $\left(3,5 \times 10^{-8}\right.$ à $\left.2,5 \times 10^{-7} \mathrm{~mol} \mathrm{~L}^{-1}\right)$.

Figura 62- Espectros de excitação e emissão da solução aquosa de tioflavina T a 2,0 x 10-5 $\mathrm{molL}^{-1}$ em tampão fosfato $0,02 \mathrm{~mol} \mathrm{~L}^{-1}$ $(\mathrm{pH} 7,1)$.

Figura 63- Espectros de emissão $\left(\lambda_{\text {exc }}=.350 \mathrm{~nm}\right)$ das soluções

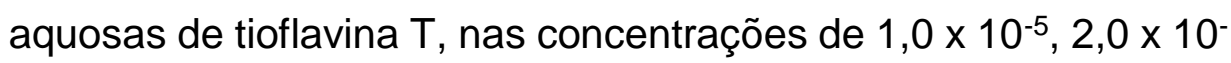
${ }^{5}$ e $3,0 \times 10^{-5} \mathrm{molL}^{-1}$, adicionadas à $6,32 \times 10^{-1} \mathrm{mg} \mathrm{mL}^{-1}$ de fração purificada de AChE suspensa em tampão fosfato $0,03 \mathrm{~mol} \mathrm{~L}^{-1}(\mathrm{pH}$ 7,0). As medidas foram feitas em intervalos de $10 \mathrm{~min}$.

Figura 64- Espectros das soluções de tioflavina nas concentrações de $4,0 \times 10^{-5} \mathrm{~mol} \mathrm{~L}^{-1} \mathrm{e} 5,0 \times 10^{-5} \mathrm{molL}^{-1}$, na presença de $6,32 \times 10^{-1} \mathrm{mg} \mathrm{mL}^{-1}$ de AChE purificada em tampão fosfato de sódio $0,03 \mathrm{molL}^{-1}(\mathrm{pH} 7,0)$. 
Figura 65- Espectros de solução aquosa de tioflavina T a 1,1 x 10${ }^{5} \mathrm{~mol} \mathrm{~L}^{-1}$ titulada com a fração protéica em três concentrações de extrato: $2,1 \times 10^{-1} ; 4,3 \times 10^{-1}, 6,3 \times 10^{-1} \mathrm{mg} \mathrm{mL}^{-1}$.

Figura 66- Espectro de emissão da BSA a $8 \times 10^{-5} \mathrm{~mol} \mathrm{~L}^{-1}$ e da tioflavina [ 2,0 $\left.\times 10^{-5} \mathrm{~mol} \mathrm{~L}^{-1}\right]$ após incubação em tampão fosfato de sódio $0,03 \mathrm{~mol} \mathrm{~L}^{-1}(\mathrm{pH} 7,0)$.

Figura 67- Espectro de emissão da AChE purificada $\left(9,4 \times 10^{-3} \mathrm{mg}\right.$ $\mathrm{mL}^{-1}$ ) em tampão fosfato $\mathrm{pH} 7,0$ antes e após a adição de 1,0 $\times 10^{-}$ $5 \mathrm{~mol} \mathrm{~L}^{-1}$ de tioflavina $\mathrm{T}$. No detalhe o espectro de emissão da solução de tioflavina na mesma concentração adicionada.

Figura 68- Espectros de emissão da solução de tioflavina a 5,3 $x$ $10^{-5} \mathrm{~mol} \mathrm{~L} \mathrm{~L}^{-1} \mathrm{em}$ um meio contendo a fração protéica e diferentes concentrações do inibidor metomil.

Figura 69- Curva de Stern-Volmer da supressão de fluorescência da tioflavina na presença da fração protéica de cérebro [4,3 X 10-1 $\mathrm{mg} \mathrm{mL}$ ] na presença de diferentes concentrações de metomil.

Figura 70- Curvas de Stern-Volmer para a fração protéica e para a tioflavina T medidas sob as condições de $280 / 345 \mathrm{~nm}$ e 350/460 $\mathrm{nm}$, respectivamente em ensaios de titulação com metomil na faixa de concentração de 2,0 x 10-8à $1,4 \times 10^{-7} \mathrm{~mol} \mathrm{~L}^{-1}$.

Figura 71- Curva de Stern-volmer para a fluorencência da fração protéica (cérebro) e para a tioflavina $\mathrm{T}$ em ensaios de titulação na presença de metamidofós na faixa de concentração de 2,0 × 10-6 a $1,8 \times 10^{-7} \mathrm{molL}^{-1}$.

Figura 72- Curva analítica da galantamina na faixa deconcentração

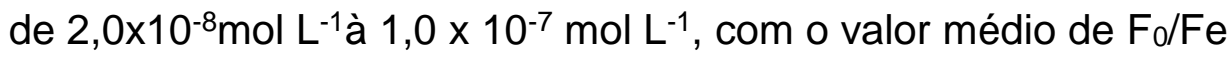
desvio-padrão. Média de quatro titulações independentes.

Figura 73- Curva analítica da atropina na faixa deconcentração de $2,0 \times 10^{-8} \mathrm{~mol} \mathrm{~L}^{-1}$ à $1,4 \times 10^{-7} \mathrm{~mol} \mathrm{~L}^{-1}, \mathrm{com}$ o valor médio de $\mathrm{Fo} / \mathrm{Fe}$ desvio-padrão. Médiade quatro titulações independentes.

Figura 74- Curva analítica do metomil na concentração de 2,0 X 10$8 \mathrm{~mol} \mathrm{~L}^{-1}$ à $1,4 \times 10^{-7} \mathrm{~mol} \mathrm{~L}^{-1}$, com o valor médio de $\mathrm{F} / \mathrm{Fe}$ desviopadrão. Média de quatro titulações independentes. 
Figura 75- Curva analítica de metamidofós na faixa de concentração de $5,0 \times 10^{-7} \mathrm{~mol} \mathrm{~L}^{-1}$ à $3,0 \times 10^{-6} \mathrm{~mol} \mathrm{~L}^{-1}$,com o valor médio de $\mathrm{Fo} / \mathrm{Fe}$ desvio-padrão. Média de quatro titulações independentes.

Figura 76- Curva analítica de metil paration na faixa de concentração de $5,0 \times 10^{-7} \mathrm{~mol} \mathrm{~L}^{-1}$ à $3,0 \times 10^{-6} \mathrm{~mol} \mathrm{~L}^{-1}$,com o valor médio de $\mathrm{Fo} / \mathrm{Fe}$ desvio-padrão. Médiade quatro titulações independentes.

Figura 77 - Efeito de diminuição da fluorescência da escopolamina sobre a fração protéica. A curva exponencial representa essa contribuição mostrando saturação em $16 \mu \mathrm{g} \mathrm{L}^{-1}$.

Figura 78- Curvas de titulação da fração protéica com galantamina

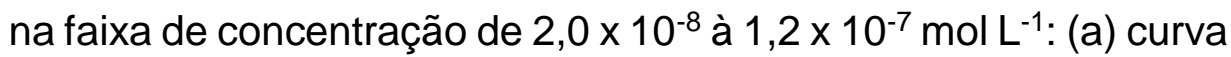
de referência de Gal em tampão fosfato; (b) adição de $30 \mu \mathrm{L}$ de amostra de urina (in natura) fortificada.

Figura 79 - Curva de inibição da AChE pelos organofosforados metamidofós e metil paration na faixa de concentração de 5,0 X 108 à $45 \times 10^{-8} \mathrm{~mol} \mathrm{~L}^{-1}$.

Figura 80-Espectro da suspensão da fração protéica em tampão fosfato após a ressuspensão de $250 \mu \mathrm{L}$ do extrato de solo (0-10 $\mathrm{cm})$. A linha preta se refere à excitação em $280 \mathrm{~nm}$ e a vermelha em $380 \mathrm{~nm}$.

Figura 81- Cromatogramade amostra de urina fresca fortificada com os analitos(1) metomil, (2)Gal, (3) atropina, (4) metil paration 


\section{Lista de tabelas}

Tabela 1 - Tabela com os níveis do planejamento $2^{3}$ (com pontos centrais e axiais) e os respectivos valores das variáveis reais e codificadas.

Tabela 2 - Concentração dos cinco analitos utilizadas nos ensaios de otimização de fluorescência e de cinética da AChE presente na fração protéica.

Tabela 3 - Valores das faixas de concentrações de cada analito usada na titulação da fração protéica e da AChE purificada.

Tabela 4 - Faixa das concentrações dos analitos para a titulação com a fração protéica e a tioflavina $T$.

Tabela 5 - Tabela com o rendimento da extração indicando a perda de atividade específica da AChE na a obtenção da fração protéica final.

Tabela 6 - Resultado da análise de ANOVA do modelo de regressão.

Tabela 7 - Tabela ANOVA do modelo de regressão para a atividade aparente da AChE presente na fração protéica.

Tabela 8 - Tabela ANOVA com os parâmetros de regressão.

Tabela 9 - Tabela ANOVA do modelo de regressão.

Tabela 10 - Tabela ANOVA do modelo de regressão quadrática para a resposta de intensidade de fluorescência da fração protéica.

Tabela 11 - Tabela ANOVA do modelo de regressão linear.

Tabela 12 - Tabela ANOVA do modelo de regressão linear sem falta de ajuste importante ( $\left.F_{\text {falta de ajuste }}=6,6\right)$.

Tabela 13 - Tabela ANOVA do modelo de regressão linear (sem falta de ajuste)

Tabela 14 - Tabela ANOVA do modelo de regressão linear (sem falta de ajuste) 
Tabela 15 - Resultado da função "desejabilidade" para a resposta de diminuição da fluorescência (fração protéica).

Tabela 16 - Valores da constante Ksv determinados em 3 razões proteínas total/atropina.

Tabela 17 - Resultado de ANOVA para dois conjuntos de determinações de Gal pelo método proposto em diferentes equipamentos.

Tabela 18 -Resultado de ANOVA para dois conjuntos de determinações de atropina pelo método proposto em diferentes equipamentos.

Tabela 19 - Resultado de ANOVA para dois conjuntos de determinações de metomil pelo método proposto em diferentes equipamentos.

Tabela 20 - Resultado de ANOVA para dois conjuntos de determinações de metil paration pelo método proposto em diferentes equipamentos

Tabela 21 - Cálculo da reprodutibilidade do método proposto para os 5 analitos estudados.

Tabela 22 - Síntese com os parâmetros de desempenho das curvas analíticas dos analitos estudados.

Tabela 23 - Estudo da interferência de diferentes razões molares analito/escopolamina usando concentração de analito igual a $6,0 \times 10^{-8} \mathrm{~mol} \mathrm{~L}^{1}$

Tabela 24 - Valores médios obtidos para cada analito em soluções na presença de escopolamina. O cálculo das médias foi feito a partir de determinações em triplicata.

Tabela 25 - ANOVA das determinações dos cinco analitos para as razões molares (analito: escopolamina) de 1:1; 1:15 e 1:30.

Tabela 26 - Cálculo para a determinação seletiva dos analitos através da estimação da contribuição individual dos analitos sobre a supressão total de fluorescência.

Tabela 27 - Resultado do teste $t$ de Student para a comparação de médias dos dois métodos de determinação de Gal (proposto e HPLC) 169 
Tabela 28 - Resultado do teste t de Student para a comparação de médias dos dois métodos de determinação de metomil (proposto e HPLC).

Tabela 29 - Resultado do teste t de Student para a comparação de médias dos dois métodos de determinação de metil paration (proposto e HPLC-F-DAD).

Tabela 30 - Taxa de recuperação dos analitos nas amostras de urina pelo método proposto e o de referência.

Tabela 31 - Valores de \% recuperação para as determinações de metamidofós e metil paration.

Tabela 32 - Valores dos parâmetros de fertilidade de solos para as amostras florestais coletadas em duas profundidades em área de cobertura vegetal. ( $P$ ass. - fósforo assimilável)

Tabela 33 - Valores de recuperação dos 3 analitos nas 2 profundidades: método proposto e o método cromatográfico de referência. Valor médio de dez replicatas e desvios menores que $2,5 \%$.

Tabela 34 - Valores de \% de recuperação obtidas para a determinação de metamidofós e metil paration pelo método proposto (fluorescência) e os dois métodos de referência: cromatográfico e o cinético. 


\section{Siglas e abreviações}

EPA - United States Environmental Protection Agency

PND - Plano Nacional de Desenvolvimento

OPAS - Organização Pan Americana de Saúde

OMS - Organizaçao Mundial de Saúde

IBAMA - Instituto Brasileiro do Meio Ambiente e dos Recursos Naturais Renováveis

CCE - Comunidade ecnômica européia

EU - Uniao Européia

IUPAC - International Union of Pure and Applied Chemistry

TEPP - tetraetilpirofosfato

NADPH - dinucleotídeo de nicotinamida e adenina fosfato reduzida

$\mathrm{NADH}$ - dinucleotídeo de nicotinamida e adenina reduzida

ETEs - estações de tratamento de esgoto

FDA - Food and Drug Administration

EMEA - Agência Europeia de Medicamentos

UPLC - cromatografia líquida de ultra eficiência

UPLC-MS/MS - cromatografia líquida de ultra eficiência acoplada à espectrometria de massas sequencial

SNC - sistema nervoso central

AChE - acetilcolinesterase

GAL- galantamina

QuEChERS - do inglês: Quick, Easy, Cheap, Effective, Rigged, and Safe

CG-MS -cromatografia a gás acoplada à detector de espectrometria de massas

CG-MS/MS - cromatografia a gás acoplada à detector de espectrometria de massas sequencial

HPLC-MS -cromatografia líquida de alta eficiênci acoplada à detector de espectrometria de massas 
HPLC-MS/MS - cromatografia líquida de alta eficiência acoplada à detector espectrometria de massas sequencial

DAD-do inglês "diode array detector" (detector de aranjo de diodos)

FIA - do inglês “Flow Injection Analysis”(análise de injeção em fluxo)

CHO - colina oxidase

LAC - lacase

HPLC-UV- cromatografia líquida de alta eficiência com detecção por ultravioleta CE-MS/MS - eletroforese capilar com espectrometria de massa em detecção tandem

HPLC-UV, HPLC-F e HPLC-MS/MS

SDS - sodium dodecyl sulfate (dodecil sulfato de sódio)

MALDI - do inglês Matrix Assisted Laser Desorption Ionization

TLC -do inglês "thin layer chromatography" (cromatografia em camada fina)

RRA - radiorreceptoresensaio

RIA - radioimunoensaio

Trp - Triptofano

Tir - Tirosina

Fen- Fenilalanina

Glu - Ácido glutâmico

Ser - Serina

His - Histidina

PAS - sítio aniônico periférico

TcAChE-acetilcolinesterase de Torpedo californica

ThT - tioflavina T

BSA - do inglês bovine serum albumin (albumina de soro bovino)

DTNB - ácido 5,5'-ditio-bis (2-nitrobenzóico)

LANEC/PUC-Rio - Laboratório de Neurociências e Comportamento

$\mathrm{K}_{\mathrm{m}}$ - Constante de Michaelis

$\mathrm{V}_{\mathrm{m}}$ - Velocidade máxima

ATCh - acetiltiocolina

CCD - do inglês Central Composite Design (Composto Central)

$\mathrm{K}_{\mathrm{sv}}-$ Constante de Stern-Volmer

$\mathrm{K}_{\mathrm{a}}$ - constante de ligação

nAChR - receptores colinérgicos 
LD -Limite de detecção

LQ - Limite de quantificação

$\lambda_{\mathrm{em}}-$ comprimento de onda de emissão

$\lambda_{\text {exc }}-$ comprimento de onda de excitação

u.a. - unidades arbitrárias

$\mathrm{S}_{\mathrm{r}}-$ desvio padrão da repetitividade

$\mathrm{S}_{\mathrm{R}}$ - desvio padrão da reprodutibilidade

$\mathrm{MQ}_{\text {entre }}$ - mínimos quadrados entre analistas

$\mathrm{MQ}_{\text {dentro }}$ - mínimos quadrados dentro das replicatas

INMETRO- Instituto Nacional de Metrologia, Normalização e QualidadeIndustrial 


\section{INTRODUÇÃO}

\section{1.}

\section{Neurotoxinas}

\subsubsection{Neurotoxinas e exposição humana}

Muitas substâncias presentes no cotidiano da população podem afetar o funcionamento normal do cérebro desde as fases iniciais de desenvolvimento intrauterino [1]. As injúrias ao sistema nervoso causadas por substâncias tóxicas no ambiente são um grave problema de saúde públicae as formas de exposição abrangem desde a dieta alimentar, o consumo de álcool, tabaco, drogas, até as exposições ocupacionais e ambientais (ar, solo, águae biota). Um dos maiores desafios é esclarecer a associação entre a exposição humana e os efeitos dessa ssubstâncias nos sistemas neurofisiológicos. Nesse contexto, muitos estudos, envolvendo áreas multidisciplinares, ainda são necessários.

Ao longo das últimas décadas, aumentaram de forma significativa as taxas de doenças neurológicas como o autismo, o déficit de atenção, a hiperatividade, o retardo mental e paralisia cerebral. Por isso, alguns estudos recentes indicam que há uma possível ligação entre alguns desses distúrbios neurológicos e a exposição às neurotoxinas no ambiente .Por outro lado, o estudo comportamental relacionado aos efeitos de produtos químicos ou agentes terapêuticos em doses tóxicas é uma abordagem relativamente nova dentro da neurotoxicologia [2].

A toxicidade subclínica causada por substâncias químicas no ambiente, muitas delas reconhecidamente neurotóxicas, podecausar efeitos após uma pequena exposição suficiente para produzir sintomas como redução das habilidades cognitivas, pequenos lapsos de atencão, alterações de comportamento e fadiga. Embora sutis, as mudança nas funções neurológicas produzidas por sua neurotoxicidade subclínica podem ser permanentes e irreversíveis já que o sistema 
nervoso tem dificuldade de reparar certas injúriasno tecido nervoso.A identificação da neutoxicidade subclinica dessas substâncias pode auxiliar nos estudos dos eventos de exposição eseus efeitos neurofisiológicos na população humana e animal [3].

As exposições aos pesticidas representam uma preocupação especial considerando seu mecanismo de ação na bioquímica das células. Esses alvos bioquímicos são comuns em uma ampla diversidade de organismos, incluindo os mamíferos.Tendo reconhecido o risco potencial para a integridade do cérebro em desenvolvimento, a EPA (United States Environmental Protection Agency) recentementecomeçou a classificar cerca de 140 pesticidas já registrados com relação à sua neurotoxicidade [4].

\subsection{2.}

\section{Agrotóxicos}

O termo "agrotóxico" ao invés de "defensivo agrícola" passou a ser utilizado, no Brasil, para denominar os agroquímicos agrícolas, após grande mobilização da sociedade civil. Esta denominação coloca em evidência a toxicidade desses produtos para o meio ambiente e a saúde humana. $\mathrm{O}$ aumento da produção e utilização de tais produtos se insere no atual contexto de demanda por maiores quantidades de alimento exigido pelo aumento progressivo da população. Para tanto, os agrotóxicos são fundamentais para diminuir as perdas nas lavouras e assegurar o desenvolvimento de culturas em larga escala com alta produtividade.

No Brasil, os pesticidas foram primeiramente utilizados em programas de saúde pública, no combate a vetores e no controle de parasitas, passando a ser utilizados mais intensivamente na agricultura a partir da década de 1960, tendo papel fundamental noprocesso denominado de Revolução Verde. Neste período, o processo de difusão de um modelo agrícola para as regiões do Terceiro Mundo contava, principalmente, com estratégias de valorização do uso de agroquímicos de forma geral (agrotóxicos e demais insumos agrícolas). Assim, os pesticidas foram responsáveis pela consolidação do padrão tecnológico da agricultura moderna intensiva através das técnicas de controle fitossanitário das culturas [5].

Em 1975, o Plano Nacional de Desenvolvimento (PND), responsável pela abertura do Brasil ao comércio de agrotóxicos, condicionou o agricultor a comprar 
o agrotóxico com recursos do crédito rural, ao instituir a inclusão de uma cota definida de agrotóxico para cada financiamento requerido [6]. Essa obrigatoriedade, somada à propaganda dos fabricantes, determinou um enorme incremento e disseminação da utilização dos agrotóxicos no Brasil. Muitos desses produtos não possuem antídotos e são proibidos em seus países de origem.

O Brasil é o maior mercado de agrotóxicos do mundo e essa indústria movimentou no ano de 2011 o montante de US\$ 7,1 bilhões, perdendo para os US\$ 6,6 bilhões do segundo colocado, os Estados Unidos. Apesar do grande volume de recursos movimentados pela indústria no mercado brasileiro, o consumo por hectare ainda é pequeno em relação a outros países, ficando atrás de outros países com o França e Japão [7].

As culturas brasileiras de maior consumo de pesticidas são a soja, o milho, a cana-de-açúcar e as culturas de cítricos. As três primeiras das citadas culturas não requerem aplicação intensa de agrotóxicos, porém ocupam extensas áreas para a produção. Um relatório de atividades do ano de 2010 apresentou o carbendazim como o grupo químico mais encontrado nas amostras (pimentão, abacaxi, alface, couve, morango e repolho). Ingredientes ativos, do grupo químico organofosforado, também apresentaram elevado número de ocorrências: o clorpirifós, o metamidofós e o acefato [8].

Ao reconhecer o potencial perigo sanitário da situação, a Portaria Normativa IBAMA n ${ }^{\circ} 84$ de 15/10/96 instituiu o Sistema Permanente de Avaliação e Controle de Agrotóxicos e o Decreto 4.074/2002 que preconiza o monitoramento dos agrotóxicos no ambiente, em condições reais, o qual faz parte da avaliação no processo de registro de novos produtos ou da reavaliação de produtos já em uso.

A Lei Federal n. ${ }^{\circ} 7.802$ de 11/07/89, regulamentada pelo Decreto $n^{\circ} 98$ 816, no seu artigo $2^{\circ}$, inciso I, dispõe desde a pesquisa, transporte, comercialização e destino final dos resíduos e define o termo "agrotóxicos" da seguinte forma: "Os produtos e os componentes de processos físicos, químicos ou biológicos destinados ao uso nos setores de produção, armazenamento e beneficiamento de produtos agrícolas, nas pastagens, na proteção de florestas nativas ou implantadas e de outros ecossistemas e também em ambientes urbanos, hídricos e industriais, cuja finalidade seja alterar a composição da flora e da fauna, a fim de preservá-la da ação danosa de seres vivos considerados nocivos, bem como substâncias e 
produtos empregados como desfolhantes, dessecantes, estimuladores e inibidores do crescimento".[9]

Devido agrande persistência e toxicidade ambiental da $1^{\mathrm{a}}$ geração de agrotóxicos (organoclorados), eles foram substituídos pelos organofosforados e carbamatos, introduzidos no mercado brasileiro na década de 1980. Entretanto este novo grupo de agrotóxicos apresenta maior toxicidade aguda a saúde humana e animal, efeito mutagênico e teratogênico. A maioria desses pesticidas não é seletivae por isso também é tóxica para as espécies não-alvo. O mecanismo de ação dessas substâncias é sobre a química de neurotransmissãoe/ou sobre seus canais iônicos podendo causar efeitos neurotóxicos fatais. Além desses, alguns herbicidas e fungicidas, com mecanismos de ação bem diferentes também possuem propriedades neurotóxicas. Os efeitos desses compostos sobre o sistema nervoso podem envolver sua toxicidade aguda, como no caso da maioria dos inseticidas, ou crônica podendo contribuir para doenças neurodegenerativas, principalmente doença de Parkinson [10]. Os piretróides e os ditiocarbamatos (fungicidas) foram introduzidos posteriormente como uma alternativa de menor toxicidade $\mathrm{e}$ persistência ambiental. No entanto, apesar de sua progressiva disseminação, os carbamatos e organofosforados continuam ocupando significativa fatia do mercado nacional.

A família dos carbamatos compreende substâncias utilizadas como inseticidas, herbicidas e fungicidas. De um modo geral, os carbamatos inseticidas subdividem-se em: n-metilcarbamatos e n,n-dimetilcarbamatos, podendo ambos estarem associados a heterociclos aromáticos ou a função oxima, sendo então conhecidos por carbamatos heterocíclicos e carbamatos de oxima [11].

O primeiro n,n-dimetilcarbamato foi sintetizado em 1947, o Pirimicarb, e em 1957 o primeiro n-metilcarbamato, o Carbaril (Sevin (®)). Estes dois produtos, juntamente com o Propoxur (Baygon ${ }^{\circledR}$ ), introduzido pela Bayer em 1959, ainda são amplamente utilizados no Brasil [12]. Os carbamatos de oxima foram desenvolvidos pela Du Pont e lançados no mercado como um novo inseticida de estrutura semelhante ao neurotransmissor acetilcolina: o aldicarbe (Temik $\left.{ }^{\circledR}\right)$. Este é ainda amplamente utilizado, inclusive na sua forma sólida em domicílios e plantações, popularmente conhecido como "chumbinho" e atualmente proibido no estado do Rio de Janeiro. 
A maioria dos envenenamentos por agrotóxicos nos países em desenvolvimento é causada por organofosforados neurotóxicos e carbamatos. Esses compostos, inibidoresdas enzimas colinesterases, são tambémum problema de saúde pública em alguns países desenvolvidos. A possibilidade de efeitos de envenenamento a longo prazo causados por estes inibidores é uma preocupação global [13]. Devido à elevada toxicidade aguda e riscos para a população, alguns pesticidas neurotóxicos estão incluídos nas Diretivas 76/464/CEE [14] e em 60/2000/EU ou na regulamentaçãode alimentos da Comunidade Econômica Européia [15].

Diante desse cenário, é grande a preocupação sobre o risco de envenenamentode reservatórios de água por agentes neurotóxicos que embconcentrações muito baixaspodem produzirenvenenamento agudona população. Assim, torna-se urgente o desenvolvimento de métodos rápidos, confiáveis ede baixo custo que possam determinar a presença de substâncias que afetam atransmissão nervosaem humanos ou na fauna [16].

\subsubsection{1.}

\section{Metilcarbamatos}

Os metilcarbamatos foram isolados a partir de substância extraída do feijão Calabar (Physostigma venenosum) em 1864. Afisostigmina (ou eserina) tem uma pronunciada ação colinérgica de inibição dasenzimas colinesterases presentes em insetos e mamíferos. Após a determinação de sua estrutura, em 1925, foram sintetizados análogos com atividade tanto no campo farmacêutico quanto agroquímico. 


\section{A. Metomil}

O metomil, $N-\{[($ methilamino)carbonyl $]$ oxi $\}$ ethanimidothioato (IUPAC), é um metilcarbamato com fórmula molecular $\mathrm{C}_{5} \mathrm{H}_{10} \mathrm{~N}_{2} \mathrm{O}_{2} \mathrm{~S}$ (Figura 1). Pertence a classe dos inseticidas carbamatos de oxima como o aldicarbe e o oxamil também amplamente utilizados para fins fitossanitários. Ele também é o metabólito de outro agrotóxico em uso, o tiodicarbe.<smiles>CNC(=O)O/N=C(/C)SC</smiles>

Figura 1- Fórmula molecular do metil-carbamato metomil

Essa substância éum inseticida de amplo espectro, com propriedades sistêmicas tóxicas para os insetos tanto por contato quanto por ingestão e não ionizável no ambiente. É um produto usado em cerca de 100 países (du Pont de Nemours, 1975) e conhecido comercialmente pelas sinonímias: Acinate, Agrinate, DuPont 1179, Flytek, Kipsin, Lannate, Lanox, Memilene, Methavin, Methomex, Nudrin, NuBait, Pillarmate [17].

O metomil existe, em princípio, sob as formas isoméricas cis e trans em relação à posição dos substituintes sobre a ligação dupla $\mathrm{C}=\mathrm{N}$. Entretanto, a forma cis é fortemente favorecida termodinamicamente e, na prática, o isômero trans não ocorre no ambiente em quantidade detectável [18]. Este composto é classificado pela EPA como altamente tóxico e de uso restrito pela sua toxicidade aguda em humanos. A formulação nacional mais difundida na região é o inseticida Lannate, solução miscível em água. A Organização Mundial de Saúde (OMS), que recomenda a classificação de pesticidas por periculosidade, lista este composto na classe dos altamente perigosos.

Esse pesticida é um carbamato altamente inibidordas enzimascolinesterases porque induz inibição reversível de sua atividade catalítica. A ligação de um 
carbamato ao sítio ativo das colinesterases, processo chamado de carbamilação, impede a ligação com seu substrato, o neurotransmissor acetilcolina. Após serem atingidos altos níveis de acetilcolina nos nervos sinápticos,os efeitos ocorrem no sistema nervoso periférico. Esse processo de intoxicação se manifesta rapidamente, sem etapas prévias de bioativação como ocorre com os pesticidas organofosforados. Os carbamatos são rapidamente metabolizados e eliminados, com rápida degradação e pouca estabilidade química [19].

Segundo a monografia ${ }^{1}$ do metomil, seu limite máximo de resíduo (LMR) (considerada como a soma de metomil e hidroxitioacetimidato de metil, expressa como metomil) é de $3 \mathrm{mg} \mathrm{kg}^{-1}$ para verduras como brócolis, repolho e couve e de 1 $\mathrm{mg} \mathrm{kg}^{-1}$ para tomate. Classificado como extremamente tóxico (classe toxicológica I), com carência de 3 a 14 dias e aplicação foliar recomendada [20].

Os inseticidas carbamatos são absorvidos pelo organismo pelas vias oral, respiratória e cutânea. A absorção por via oral ocorre nas intoxicações agudas acidentais, nas tentativas de suicídio, sendo, portanto, a principal via implicada nos casos atendidos nos serviços de emergência. A via dérmica, contudo, é a via mais comum das intoxicações ocupacionais, seguida da via respiratória [21].

\subsubsection{2.}

\section{Organofosforados}

Os pesticidas organofosforados são ésteres do ácido fosfórico e foram primeiramente sintetizados em 1937, na Alemanha. Por apresentarem uma extrema toxicidade (poderoso efeito sobre o sistema nervoso), foram utilizados durante a Primeira Guerra Mundial para fins bélicos. Dentre os organofoforados mais perigosos e com potencial de uso em guerras químicas e em atentados terroristas destacam-se o sarin, o somam e o tabun, que foram chamados de "gases dos nervos".

O primeiro inseticida organofosforado usado comercialmente foi o tetraetilpirofosfato (TEPP) que era extremamente tóxico a todas as formas de vida, 
porém facilmente hidrolisado quando em solução. Posteriormente, foram sintetizados compostos mais estáveis com persistência moderada no ambiente, originando o paration e, mais tarde, o paraoxon, o seu óxon análogo. Embora tais substâncias apresentassem propriedades desejáveis como inseticidas, como baixa volatilidade, estabilidade química à luz solar e na presença de água, exibiam uma marcante toxicidade em mamíferos. O número de envenenamentos severos atribuídos ao paration estimulou a pesquisa de análogos que fossem mais seletivos em suas toxicidades para os organismos alvos. O maciço emprego dos organofosforados como inseticidas deu-se a partir da década de 1970, em substituição aos organoclorados, que são altamente estáveis no ambiente e que sofrem bioamplificação na cadeia alimentar. Opostamente, os organofosforados são rapidamente degradados no ambiente, considerando as condições climáticas, da sua formulação e do método como são aplicados [22].

Apesar do mecanismo de ação comum com os metilcarbamatos (através da inibição da enzima acetilcolinesterase), os organofosforados variam quanto a sua eficiência, atuando como inibidores diretos ou indiretos. Eles estão subdivididos em diversos grupos, segundo as diferenças em suas estruturas químicas (figura 2). Os fosforotioatos (metil paration, paration, fenitrotion e outros) e os fosforoditioatos (malation, metil azinofós), amplamente utilizados nas regiões agrícolas, são caracterizados pela presença de enxofre nas moléculas, o que reduz as suas propriedades anticolinesterásicas. Os ésteres fosforotionados, como o paration, não são inibidores de colinesterases, por causa da não reatividade do grupamento tionofosfato $[23 ; 24]$. 


\section{ORGANOFOSFORADOS}

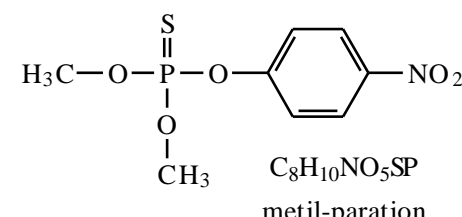

CARB AMATOS<smiles>CNC(=O)Oc1cccc2c1OC(C)(C)C2</smiles><smiles>CCOP(=S)(OCC)Oc1ccc([N+](=O)[O-])cc1</smiles>

$\mathrm{C}_{12} \mathrm{H}_{15} \mathrm{NO}_{3}$

carbofuran

$\mathrm{PM}=221,25$

$\mathrm{PM}=291,25$<smiles>COP(=S)(OC)Oc1ccc([N+](=O)[O-])c(C)c1</smiles>

$\mathrm{C}_{9} \mathrm{H}_{12} \mathrm{NO}_{5} \mathrm{~S} \mathrm{P}$

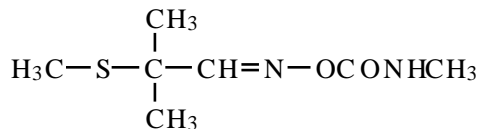

fenitrotion

$P M=277,23$

$\mathrm{C}_{7} \mathrm{H}_{14} \mathrm{~N}_{2} \mathrm{O}_{2} \mathrm{~S}$

aldicarb $\mathrm{PM}=190,26$

$\mathrm{H}_{3} \mathrm{C}-\mathrm{O}-\stackrel{\stackrel{\mathrm{O}}{\mathrm{I}} \underset{\mathrm{I}}{\mathrm{N}}-\mathrm{S}}{\mathrm{NH}_{2}}-\mathrm{CH}_{3}$

$\mathrm{C}_{2} \mathrm{H}_{8} \mathrm{~N} \mathrm{O}_{2} \mathrm{SP}$

metamidofos

$\mathrm{PM}=141,12$

Figura 2 - Fórmula estrutural de alguns organofosforados e carbamatos.

Contudo, o metabólito do paration, o éster fosfato denominado paraoxon, é um potente agente anticolinesterásico [25]. Durante o metabolismo, os 
fosforotioatos podem sofrer ataque enzimático simultâneo em diferentes pontos da molécula. Uma das reações, a oxidação dessulfurativa de ésteres fosforotioatos, resulta em produto com toxicidade mais elavada que a do seu precursor. Estas reações de ativação, que ocorrem "in vivo", são feitas pelo sistema enzimático denominado oxidase de função mista, presente na fração microssomal do tecido hepático de mamíferos [26]. No processo são requeridos NADPH (dinucleotídeo de nicotinamida e adenina fosfato reduzida) ou NADH (dinucleotídeo de nicotinamida e adenina reduzida) e oxigênio, sendo necessária também a participação do citocromo P-450 como receptor de elétrons [27;28;29].

O metabolismo dos pesticidas organofosforados em tecidos extrahepáticos como cérebro, pulmões, pele, testículos e rins tem importância no mecanismo de toxicidade destes compostos. Certos pesticidas e seus óxon-análogos produzidos no fígado sofrem processos de detoxificação nesses tecidos e no sangue, o que impede que grandes quantidades desses metabólitos atinjam o cérebro [30]. Porém, embora a bioativação em sítios alvo possa contribuir pouco nestes casos, o mesmo não ocorre nas situações de exposição continuada e em baixas doses. Embora a bioativação em sítios alvo possa contribuir pouco nestes casos, o mesmo não se pode afirmar em situações de exposição continuada e em baixas doses, como as que ocorrem nas intoxicações ocupacionais. Nestes casos, o efeito de primeira passagem para o cérebro, a partir do contato dermal, tem um papel significativo [31].

A ativação de pesticidas fosforotioatos pelas frações microssomal e mitocondrial de cérebro de rato foi demonstrada utilizando o metil paration como modelo. Esse composto, que apresentou uma maior toxicidade no animal íntegro, foi ativado pelo cérebro na sua maior extensão, sugerindo que a capacidade do cérebro em ativar oxidativamente este fosforotioato é parte crítica na mediação de sua toxicidade aguda em ratos [31].

A principal causa de morte em mamíferos expostos aos pesticidas organofosforados é a insuficiência respiratória. A seqüência de eventos que resulta neste quadro está associada à ativação hepática destes compostos, ao transporte dos metabólitos ativos através do sistema circulatório e a interferência nos mecanismos de transmissão do impulso nervoso ao nível das sinapses colinérgicas. Apesar do fígado funcionarcomo principal órgão de desintoxicação,deve-se considerar que uma percentagem relativamente alta de metabólitos tóxicos ainda são liberados na 
circulação, atacando seus alvos biológicos. Estudos indicam que uma parte do agrotóxico absorvido é liberado em sua forma inativa,sendo ativado no próprio tecido cerebral, o que o torna potencialmente mais tóxico [32].

\subsection{3.}

\section{Fármacos residuais}

A ocorrência de fármacos no ambiente têm causado crescente preocupação [33;34;35;36;37;38;39]. O destino e os efeitos de produtos farmacêuticos só recentemente se tornou uma questão de interesse ambiental, especialmente porque técnicas analíticas mais poderosas têm permitido a sua detecção e quantificação em nível traço em amostras ambientais [40;41]. Os estudos demonstram que várias dessas substâncias parecem ser persistentes no ambientee não são completamente removidas nas estações de tratamento de esgoto (ETEs) [42;43;44]. Fármacos de uso humano e animal foram detectados em ETEs, no próprio lodo de esgoto, em águas superficiais como rios, lagos, estuários,áreas costeiras e até na água destinada ao consumo humano $[41,45 ; 46 ; 47]$.

Os ingredientes farmacêuticos, incluindo seus metabólitos e conjugados, são excretados principalmente na urina ou fezes. Assim, eles entram em sistemas de tratamento de esgoto onde podem ser degradados, adsorvidos para lamas de depuração,ou eventualmente diluído nas águas de superfície. Os produtos farmacêuticos de uso vererinário também são uma via importante de contaminação já que estas substâncias estão presentes nas fezes e naurina eliminadas diretamente sobre o solo e os corpos dágua.Além do fluxo de escoamento superficial e lixiviação transportarem essas substâncias até águas superficiais e subterrâneas, a atividade de aquicultura também contribui significativamente para sua entrada nos ambientes aquáticos. Por isso, muitos ingredientes farmacêuticos ativos para uso humano e animal são encontrados em amostras de águas superficiais, águas subterrâneas e até em reservatórios de água potável [45].

Embora não sejam novidades como contaminantes, as informações relativas à concentração e destino ambiental de fármacos e metabólitos foram relatados apenas nos últimos anos [48;49]. Alguns estudos têm demonstrado os efeitos sinérgicos desses compostos [50] presentes em águas de superfície em 
concentrações traço [51]. Alguns medicamentos causam efeitos adversos em concentrações ainda menores como o etinilestradiol, a ivermectina e levonorgestrel [52-54]. Essas concentrações são geralmente consideradas muito baixas para representar um risco grave para os seres humanos. No entanto, ainda é desconhecido se outros organismos não-alvo, como os organismos aquáticos, são sensíveis a esses resíduos ou à suas misturas [50].

Além disso,muitas espécies aquáticas (especialmentepeixes e anfíbios) possuem moléculas-alvo para as drogas semelhantes aos do organismo humano e de outros mamíferos [55;56]. Por isso, as interações farmacológicas em espécies não-alvo podem ocorrer com efeitos potencialmente adversos.Um exemplo relevante desse evento são os efeitos do 17a-etinilestradiol, o estrogênio sintético presente em muitos anticoncepcionais, sobre a diferenciação sexual e a fertilidade dos peixes que vivem a jusante de usinas de tratamento de esgoto [57;58].

Portanto, apesar do conhecimento da presença de produtos farmacêuticos, pouco ainda é conhecido sobre seu comportamento, em termos de destino e os efeitos, após a sua entrada no ambiente. A necessidade de desenvolver estratégias, incluindo testes baseados em seu modo de ação em mamíferos a partir de dados farmacocinéticos e farmacodinâmicos, foi reconhecida pela indústria, autoridades governamentais e academia [59-61] . Já existe um conhecimento dos impactos das drogas através dos testes padronizados de segurança [62]. Portanto, uma opção seria a utilização desses dados disponíveis para mamíferos em uma avaliaçãoda probabilidade dessas drogas causarem efeitos farmacológicos em outras espécies [54].

Avaliações de risco ecológico dos produtos farmacêuticos foram formuladas pela FDA e pela Agência Europeia de Medicamentos (EMEA), como parte do processo de aprovação para o uso de novas drogas [63;64]. O documento para discussão divulgado pela EMEA recomendou a avaliação do potencial de interação dos fármacos com sedimentos durante o processo de avaliação de risco [60] já que a interação com sedimentos pode modificar a toxicidade potencial aos organismos vivos nos ecossistemas aquáticos [65;66]. No entanto, a ecotoxicidade de uma série de drogas de uso farmacêutico e de higiene pessoal, que foram introduzidos no mercado antes destas diretrizes, é ainda pouco conhecida [67].

O crescente número de estudos de monitoramento dessas substâncias tem exigido o emprego de métodos eficientes. Por essa razão, um grande esforço está 
direcionadoao desenvolvimento de métodos rápidos e, ao mesmo tempo, confiáveis capazes de analisar simultaneamente vários compostos pertencentes a grupos terapêuticos diferentes. Uma das opções, cada vez mais usada em análise ambiental, é a cromatografia líquida de ultra eficiência (sigla em inglês: UPLC) que emprega colunas que permitem a eluição dos componentes da amostra em menor tempo e com maior resolução cromatográfica. Esta técnica vem sendo aplicada para a determinação de produtos farmacêuticos usando UPLC-MS/MS (triplo quadrupolo ) $[68 ; 69 ; 70 ; 71]$. Diversas otimizações vem sendo feitas para aumentar o número de compostos monitorados e sua aplicação em diferentes matrizes (águas subterrâneas, águas superficiais e águas residuais) [50].

A pesquisa farmacêutica (industrial e acadêmica) têm buscado intensamente a descoberta e síntese de novos compostos que possam ser usados como drogas no combate a inúmeras doenças. Como exemplo, pode-se citar as diversas formas de câncer e doenças degenerativas como as reumáticas, ósseas e neurológicas, como Parkinson e Alzheimer. Em todos esses casos, se observa o uso maciço dos antiinflamatórios e de drogas de ação em neurotransmissores(parte da classe dos neuroterápicos). A frequiência cada vez maior dessas doenças faz aumentar, proporcionalmente, a fabricação e consumo dessas drogas e consequentemente seu aporte ambiental [72;73] . Por isso, as drogas colinérgicas e colinerterásicas apresenta um alvo importante da pesquisa ambiental relacionado a sua entrada no ambiente e suas interações físico-químicas e biológicas.

\subsubsection{1.}

\section{Fármacos colinérgicos e anticolinesterásicos}

Os fármacos colinérgicos exercem sua ação sobre o sistema autônomo (efeitos parassimpatomiméticos), sobre os gânglios autônomos, junções neuromusculares e células efetoras. Os efeitos apresentam amplo espectro de ação, dependendo do tipo de neuroreceptor colinérgico envolvido: muscarínico ou nicotínico. 
Os agentes colinérgicos muscarínicos manifestam pequena especificidade pelos diferentes subtipos desses receptores. Eles são classificados em dois grandes grupos: i) os de ação direta sobre o neuroreceptor, como ocorre com oneurotransmissoracetilcolina ou seus antagonistas e ii) os de ação indireta que garantem a integridadedo neurotransmissor(acetilcolina) da hidrólise pelas enzimas colinesterases.Os antagonistas muscarínicos bloqueiam os vários subtipos de receptores (muscarínicos) através do mecanismo de antagonismo competitivo reversível. Dessa forma, seus efeitos podem ser revertidos aumentando-se a concentração de acetilcolina (neurotransmissor) no meio através do uso de anticolinesterásicos.

Os fármacos chamados anticolinesterásicos inibem as enzimas da família das colinesterases responsáveis pela hidrólise da acetilcolina, prolongando tanto suas ações muscarínicas quanto nicotínicas. Por esta razão, são denominados agentes colinérgicos de ação indireta. Os diferentes compostos dessa classe, independente de seu modo de ação, agem diretamente no sistema de neuroquímicos. Isto acontece por interações provocadas nas ações dos neurotransmissores ou receptores nas regiões do tecido nervoso através de diferentes interações com proteínas, sejam elas com funções catalíticas (enzimas) ou estruturais (neuroreceptores de membrana) como representado no esquema da figura 3.

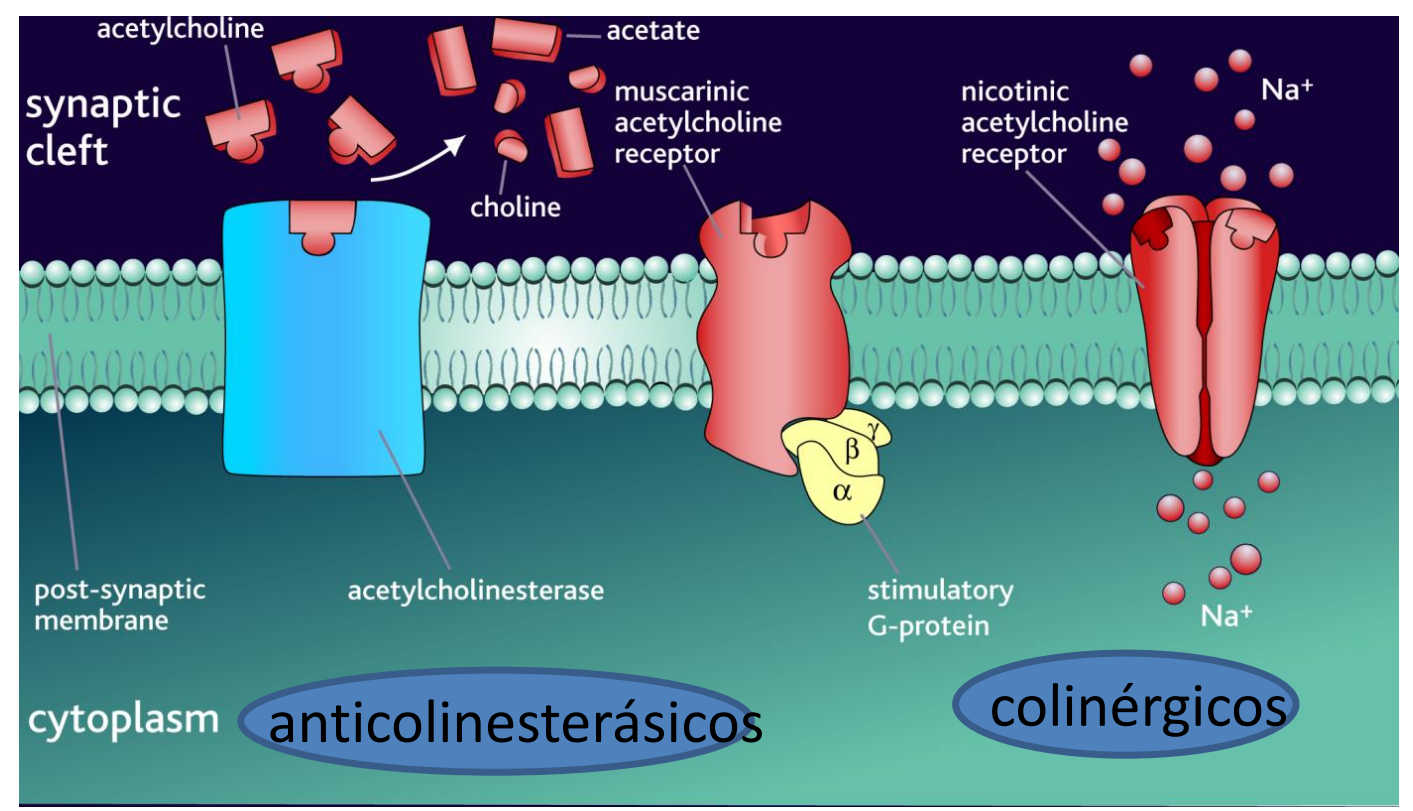

Fonte: www.CNSforum.com/Lundbeck Institute 
Figura 3 - Representação esquemática dos mecanismos de ação dos fármacos colinérgicos e colinesterásicos sobre os receptores de membrana e sobre a enzima acetilcolinesterase.

Os anticolinesterásicos atuam sobre as sinapses colinérgicas, a junção neuromuscular e o sistema nervoso central (SNC). Seus efeitos tóxicos incluem bradicardia, hipotensão, secreções excessivas, broncoconstrição, hipermotilidade gastrintestinal e redução da pressão intra-ocular. A ação no SNC determina excitação inicial que pode resultar em convulsões, seguidas de depressão, podendo causar perda de consciência e insuficiência respiratória [74].

As principais indicações terapêuticas dos agentes anticolinesterásicos são relativas ao aparelho visual, intestino e junção neuromuscular. Os inibidores das colinesterasessão indicados no tratamento de glaucoma e para induzir o aumento da motilidade dos tratos intestinal e urinário após procedimentos cirúrgicos [75]. Estes neuroterápicos também são empregados no tratamento dos sintomas iniciais da doença de Alzheimer, um estado de demência progressiva caracterizada por uma diminuição da transmissão colinérgica no SNC.

Entre os inibidores da acetilcolinesterase podemos destacar a galantamina, muito usado no tratamento da Doença de Alzheimer e a atropina, muito utilizada como antídoto de intoxicações por pesticidas.

\section{I) Galantamina}

A Doença de Alzheimer é uma doença neurodegenerativa muito frequente que leva à demência, ao declínio progressivo da função cognitiva, e à perda progressiva da memória [76]. Esta doença está associada a insuficiência colinérgica e por isso, um dos seus tratamentos é baseado no uso dos agonistas colinérgicos e dos inibidores da acetilcolinesterase (AChE). A Galantamina (GAL) representada na Figura 3, um alcalóide presente na família Amaryllidaceae e comercializado como Reminyl ${ }^{\circledR}$ (Janssen), faz parte da terceira geração de medicamentos para tratar a doença. É a única droga que ativa a transmissão colinérgica, aumentando a concentração do neurotransmissor acetilcolina (ACh) pela inibição da enzima acetilcolinesterase (AChE) no cérebro e,ao mesmo tempo, faz a regulação de 
agonistas dos receptores nicotínicos [77;78]. Esta droga, que possui este mecanismo duplo de ação, tem mostrado maior eficácia no combate aos sintomas da doença [79;80;81]. Por isso tem sido relatados muitos estudos sobre sua farmacocinética, a relação entre dose e efeito, a eficácia do tratamento, tolerabilidade e efeitos sinérgicos com outras drogas [82; 83].

Váriasvias metabólicase de excreçãorenalestão envolvidos na eliminaçãoda galantamina sendo metabolizadapelaenzimas hepáticas do citocromo P450, glucoronidadoeexcretado naurina.Não foi observado uma via metabólica predominante sendo seus metabólitosformadosdiretamenteporglucuronidação, Odesmetilação, N-oxidação, epimerização, N-desmetilação e conjugaçãode sulfato [84]. Este mesmo estudo demonstra a presença degalantaminaedois metabolitosno plasma, o glicuronídeo de O-desmetil-galantamina e o glucuronídeo de galantamina.

Por causa do aumento da população afetada pelo Mal de Alzheimer e da toxicidade potencial (humana e ambiental) da GAL, a quantificação de seus resíduos e metabólitos, em fluidos biológicos ou amostras ambientais, tornou-se importante. Casos desse tipo de exposição humana (à agentes nervosos) tem sido relatada por estudos que indicam uma associação entre a exposição destes xenobióticos e a saúde humana, incluindo distúrbios no sistema nervoso central [83].<smiles>COc1ccc2c3c1O[C@H]1C[C@@H](O)C=C[C@@]31CCN(C)C2</smiles>

Figura 4 - Fórmula estrutural da galantamina.

II) Atropina 
A atropina é uma mistura racêmica da $d$-hiosciamina e $l$-hiosciamina, sendo um antagonista competitivo dos receptores muscarínicos, também chamado de fármaco parassimpatolítico, pois é capaz de bloquear seletivamente os efeitos da atividade nervosa parassimpática. Sua estrutura consiste de um grupo éster do ácido trópico (tropinol) e um grupo básico. Sua estrutura é parecida com a da acetilcolina, porém possui um grupo aromático no lugar do grupo acetil [85] (Figura 4). A atropina é um alcalóide amônio terciário, suficientemente lipossolúvel sendo rapidamente absorvido pelo intestino e pelo saco conjuntival e, principalmente, nas barreiras hematocefálicas.

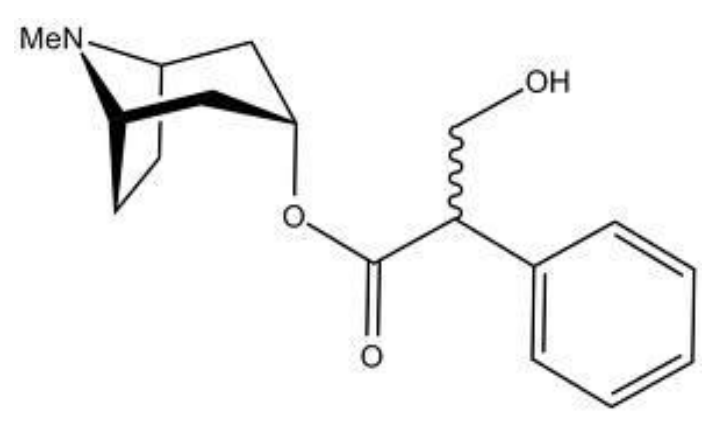

Figura 5- Fórmula da atropina.

Em sementes, folhas, flores e caule de plantas da família Solanaceae(família das Solanáceas) são encontrados ambos enantiômeros, o ativo $l$-hiosciamina e a $d$ hiosciamina [85], principalmente na espécie Atropa belladona. Os componentes da mistura racêmica de hiosciamina podem ser isoladas de plantas da família das solanáceas (ex: Atropa belladonna e Hyoscyamus niger). Um grande número de vias de síntese [86] foram descritas para a atropina, porém para fins farmacêuticos sua origem é sempre natural. Por isso, pode ser acompanhada de substâncias estruturalmente relacionadas que ocorrem nas plantas, como a norhiosciamina e seus isômeros, 6-hidroxihiosciamina, 7-hidroxihioscamina, hioscina (escopolamina) e littorina [87]. Durante o armazenamento, podem ocorrer reações de degradação produzindo a apoatropina como seu principal produto de degradação [88].

O enantiômero $l$-hiosciamina tem ocorrência natural predominante [89] e é a forma farmacologicamente ativa enquanto que a $d$-hiosciamina praticamente não tem atividade antimuscarínica [75]. Alguns dos fármacos disponíveis 
comercialmente contêm atropina como racemato, enquanto outros contêm apenas o (S)-enantiômero, correspondente a l-hioscimana, referida também como hiosciamina.

A atropina é usada frequentemente como pré-medicação em procedimentos anestésicos, antiespasmódicos, reversor de braquicardia e antídoto contra pesticidas organofosforados [90]. O sulfato de atropina tem sido amplamente utilizado para induzir a dilatação da pupila e em alguns casos para reduzir a progressão da miopia, em operações oftálmicas, como espasmódico e como antídoto para o envenenamento por ópio, eserina e muscarina [91]. Da mesma forma, uma inadequada administração desta substância pode estimular o sistema nervoso central e interromper a função renal humana levando à reação tóxica [92]. Portanto, é necessário estabelecer métodos sensíveis e eficazes para a quantificação de sulfato de atropina no campo da medicina.

O mecanismo tóxico mais importante da atropina é a inibição da enzima acetilcolinesterase $(\mathrm{AChE})$, resultando em crise colinérgica. Embora sua eficácia no tratamento dos envenenamemtos por organofosforados seja discutida, [93;94;95;96] a atropina é considerada como uma estratégia terapêutica importante. Entretanto, as recomendações sobrea sua dosagem variam consideravelmente [97;98;99]. Por isso, embora a importância da atropina no tratamento do envenenamento por organofosforados seja reconhecida,a sua administração é uma questão ainda em debate [100].

A farmacocinética da atropina é rápida e com completa absorção pelo trato gastrintestinal e também nas membranas mucosas, olhos e pele. Ela atravessa a barreira hematoencefálica e a placenta e podem ser detectada no leite materno. É metabolizada parcialmente no fígado e cerca de $50 \%$ é excretada na urina na forma inalterada. O tempo de meia-vida é de cerca de 4 horas [101].

\section{2.}

\section{MÉTODOS ANALÍTICOS}




\subsection{1.}

\section{Metomil}

Vários métodos multi-resíduo para a determinação demetil-carbamatos foram desenvolvidos. Normalmente esses métodos são precedidos de etapassimplificadas deextração do analito da amostra e limpeza de matriz quevariam da extração líquido-líquido a micro-extrações em fase sólida. Em especial, a estratégia denominada QuEChERS (do inglês: Quick, Easy, Cheap, Effective, Rigged, and Safe) tem sido aplicadas [102] consistindo de uma etapa de extração inicial em acetonitrila, etapa de partição após a adição de sal e uma etapa de limpeza utilizando extração em fase sólida dispersiva.. Este método (QuEChERS) foi aplicado em análises multiresiduais de agrotóxicos(organofosforados e carbamatos) em frutas e vegetais [103] hortaliças [104]. As recuperações obtidas ficaram em torno de $95 \%$ para as duas classes de pesticidas.

A ocorrência de inúmeros casos de envenenamento faz parte da história de uso dos carbamatos, tendo impulsionado métodos de determinação simultânea de diferentes classes de herbicidas e inseticidas em amostras biológicas como sangue, plasma, urina e tecidos usando a cromatografia a gás acopladacom detecção por espectrometria de massa (GC-MS e GC-MS/MS) e cromatografia a líquido de alta eficiência acoplada com detecção por espectrometria de massa (HPLC-MS e HPLC-MS/MS).Em amostras de urina esses métodos têm permitido o alcance de limites de quantificação para o metomil na faixa de 0,011 a $3,5 \mu \mathrm{gL}^{-1}$ [105].

A separação por eletroforese capilar de quatro carbamatos em amostras de água permitiram limites de detecção entre 3 e $6 \times 10^{-8} \mathrm{~mol} \mathrm{~L}^{-1}$ usando detecção amperométrica [106].

Métodos fotométricos [107], voltamétricos [108] e fluorimétricos [109] foram desenvolvidos para determinação total de metilcarbamatos e requerem etapas prévias de separação. Alternativamente esses métodos utilizam modelos de calibração multivariada [110]. A determinação simultânea dos pesticidas carbamatos:propoxur, isoprocarb, carbaril e carbofuran foi feita com a aplicação de modelos de calibração multivariada para facilitar a resolução dos voltamogramas e resultou em curvas de calibração na faixa de 1 a $3 \mu \mathrm{g} \mathrm{L}^{-1}$ [110].Um método fotométrico aplicado a amostras de água e frutas permitiuquantificaçõesnafaixa de 
concentração de 0,5 à $10,0 \mu \mathrm{gmL}^{-1}$ com limite de detecção de $0,4 \mathrm{gmL}^{-1}$ para ometilcarbamato carbofuran [111]. Pelo fato dos carbamatos apresentarem precária ou nenhuma fluorescênciao desenvolvimento de métodos analíticos fluorimétricos exigiu o uso de meios organizadoscomo ciclodextrina e a quitosana para permitir a amplificação e medição de fluorescência, alcançando limite de detecção da ordem de 0,1 a $1 \mu \mathrm{g} \mathrm{mL} \mathrm{m}^{-1}$ (em amostras de fruta e água) [112].

Amostras complexas analisadas por HPLC com detecção fotométrica em um detector de aranjo de diodos (DAD) apresentaram co-eluição de analitos, deformação dos cromatogramas na dimensão temporale interferências. Esses problemas exigiram a aplicação de modelos multivariados permitindo prever,satisfatoriamente, as concentraçõesde onze pesticidas carbamatos, incluíndoometomil. Os limites de detecção para todos os analitos foram da ordemde $5 \mathrm{ng} \mathrm{mL}{ }^{-1}$ com etapa de pré-concentração em fase sólida [113]. A calibração multivariada também permitiu a detecção por HPLC-DAD de concentrações de metomil em água de rio e água da estação de tratamento de esgoto em torno de $1 \mu \mathrm{g}$ $\mathrm{L}^{-1}$ (estudos com amostra fortificada) [114].

Inúmeros trabalhos visando à determinação específica da classede pesticidas organosfosforados e metilcarbamatos utilizam biosensores baseados nas ChEs [115]. Ele se baseia no fato de que a atividade das enzimas da classe das colinesterases (ChE) são inibidas por estes pesticidas e seu grau de inibição édependente da concentração do pesticida presente no meio. Estes métodos baseados na cinética enzimática foram adaptados à detecção fotômétrica [116;117] e eletroquímica [118;119]. Muitos dos instrumentos usados foram planejados para atender a estudos de campo com análises rápidas, de fácil operação e com sensibilidade adequada aos níveis dos analitos encontrados. Parte desses instumentos é baseada nas técnicas de análise com injeção em fluxo, desenvolvidas para melhorar a frequência analítica e para minimizar a influência do operador durante a análise. Essessistemas mais simples, denominados de FIA (do inglês "Flow Injection Analysis") consistem de um reator contendo uma enzima imobilizada combinada a um sistema de detecção [120;121]. Porém, seu desempenho é dependente dos suportes utilizados para a imobilização do biocomponente/componente enzimático [122]. Colunas para retenção e posterior eluição dos analitos de interesse podem ser acoplados, aumentando a seletividade das determinações. Recentemente, várias publicações têm mostrado esses sistemas 
para análise em micro-escala [123;124]. Esse tipo de automação e miniaturizaçãooferece novas possibilidades em termos de custo-benefício e rapidez na obtenção de resultados. Abordagens mais sofisticadas de análise com injeção em fluxo, como o SIA (do inglês "Sequential Injection Analysis"), também podem ser empregadas.

O uso de dispositivos micro-fluídicos comon sistemas analíticos também tem atraído atenção crescentenos últimos anos devido à sua redução significativa de consumo de reagentee de baixocustos operacionais, bem como capacidade de produção elevada. Esses dispositivos são capazes de controlar e manipular fluxos de fluido com escalas inferiores a um milímetro. Recentemente, monolitos à base de sílica, juntamente com dispositivos micro-fluídicos, têm sido usados comouma alternativa atraente para colunas empacotadas para a análise de substâncias de diversas naturezas [125]. Por exemplo, foi desenvolvido um sistema composto por uma base de sílica com um sistema micro-fluídico integrando uma enzima imobilizada e um detector eletroquímico baseado na inibição enzimática para determinar pesticidas (eserina, malaoxona e metomil) [126]. Outro dispositivo baseado na co-imobilização das enzimas acetilcolinesterase (AChE) e da colina oxidase $(\mathrm{CHO})$ forneceu uma abordagem mais seletiva para carbamatos por utilizar duas enzimas [127;128] com redução significativa no consumo de enzima, volume de amostra e tempo de análise [129;130]. A ligação da enzima AChE com o inibidor dentro do ambiente do micro-reator gerou um aumento na constante de inibição $\left(\mathrm{K}_{\mathrm{i}}\right)$

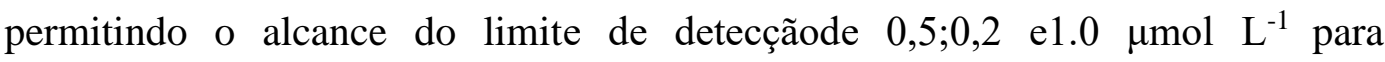
malaoxona,eserina e metomil [122].

Um sensor óptico portátil para substâncias anticolinesterásicas (AntiChEs) foi construído pela imobilização da $\mathrm{AChE}$ (obtida do órgão elétrico de enguias) em fibras de quartzo marcadas com isotiocianato de fluoresceína. A atividade enzimática foi monitorada por meio da variação da fluorescência do marcador, que édependente do $\mathrm{pH}$ que se modifica na superfície da fibra, em função dos prótons produzidos durante a hidrólise do substrato na catálise enzimática. As concentrações detectadas pelo biosensor para os inseticidas carbamatos bendiocarbe e metomil e o organofosforado paraoxon são da ordem de $\mu \mathrm{mol} \mathrm{L} \mathrm{L}^{-1} \mathrm{e}$ nmol L-1 ${ }^{-1}[131]$. Outra sonda fluorescente dependente do $\mathrm{pH}$ foi usada para detectar a inibição da $\mathrm{AChE}$ em um sistema de injeção em fluxo para a determinação de pesticidas organofosforados e carbamatos. Os limites de detecção de 3,5, 50, 12 e 
$25 \mu \mathrm{g} \mathrm{L} \mathrm{L}^{-1}$ para o carbofuran, carbaril, paraoxon e diclorvos [132], foram obtidos respectivamente.

Diversos outros biosensores eletroquímicos foram desenvolvidos com diferentes estratégias de modificações de eletrodos associada à imobilizações das colinesterases. Um biossensor amperométrico para a determinação de carbamatos em amostras de água, frutas e vegetais foi impresso sobre um suporte cerâmico à base de prata. $\mathrm{O}$ eletrodo de trabalho foi modificado por uma camada de pasta de carbono misturados com ftalocianina de cobalto (II) e acetilcelulose. Tal modificaçãodo eletrodo já havia mostrado eficiênciapara detectarteores de pesticidas em frutas e vegetais matrizes,como água do mar, água potável, soloe sedimentos [133]. Utilizando-se um pequeno volume de amostra e de enzima. (ChE) a qual foi imobilizada sobre esta camada detectou-se concentrações de carbmatos da ordem de $\mu \mathrm{gL}^{-1}$ em frutas e vegetais [134]. Modelos portáteis com imobilizações da AChE por eletropolimerização [135] ou utilizando fotopolímeros como o álcool polivinílico [136] sobre a superfície de eletrodos impressos e serigrafados foram usados em análises de amostras de alimentos. Estes permitiram o alcance de limites de detecção (metomil) menor que $10 \mu \mathrm{g} \mathrm{L}^{-1}$ [135].

Novos biosensores para metomil estão baseados no princípio de inibição da enzima lacase (LAC) em amostras de alimentos. Esta enzima é uma oxidorredutase de cobre, conhecida como calatisador "verde" por utilizar $\mathrm{O}_{2}$ como oxidante e produzir $\mathrm{H}_{2} \mathrm{O}$ como subproduto na catálise oxidativa de polifenóis substituídos, aminas aromáticas, benzenotiois e uma série de outros compostos [153]. A LAC é obtida do fungo Aspergillus oryzae cuja catálise é dependente da concentração do inibidor (metomil). Pode-se destacar uma forma de imobilização em fase líquida iônica à base de nanopartículas de platina em suporte de montmorilonita [137]. A determinação de metomil em amostras de cenoura e tomate utilizando este biossensor mostrou resultados consistentes com os obtidos por cromatografia líquida, verificando que o método desenvolvido pode ser utilizado para a quantificação deste pesticida com limites de quantificação de $7,8 \times 10^{-7} \mathrm{~mol} \mathrm{~L}^{-1}$ [137]. O desenvolvimento de um biossensor sol-gel com eletrodos a base de carbono cerâmico baseado na imobilização da lacase de Aspergillusoryzae foi aplicado com sucesso na determinação de metomil em amostras deextratos vegetais.O método alcançou um limite de deteç̧ão de $0,2 \mathrm{mmol} \mathrm{L}^{-1}$.A técnica sol-gel produz uma rede 
tridimensional que possui excelentes propriedades para imobilização de enzimas, uma vez que sua atividade biológica nativa é mantida [138;139].

\subsection{2.}

\section{Galantamina}

As determinações de galantamina (GAL) em amostras biológicas são baseadas em métodos de cromatografia líquida e eletroforese capilar acopladas a detecção por fotometria de absorção, de fluorescência e por espectrometria de massa. Em estudos de estabilidade do medicamento Reminyl® foram usados em dois métodos: cromatografia líquida em fase reversa com detecção por fotometria de absorção (HPLC-UV) e eletroforese capilar com espectrometria de massa em detecção tandem (CE-MS/MS). A GAL apresentou estabilidade em meio alcalino e em temperaturas elevadas $\left(80^{\circ} \mathrm{C}\right)$. Todos os produtos de degradação testados mostraram fraca atividades inibitória sobre a enzima AChE [151]. Na separação de misturas racêmicas da GAL por eletroforese capilar, usando $\beta$-ciclodextrina como seletores quirais, o limite de quantificação de 2 pg foi obtido usando fotometria de absorção [152]. Em estudos de farmacocinética, a quantificação dos metabólitos da GAL foi feita por HPLC-UV, HPLC-F e HPLC-MS/MS em amostras de plasma, urina, fezes e tecidos em valores da ordem do pmol $\mathrm{L}^{-1}[153 ; 154 ; 155]$. A determinação da GAL em amostras ambientais usou o HPLC-Fluorimetria em amostras de água do rio. A fraca fluorescência da GAL é significativamente melhorada emmeio micelar, formado por SDS, chegando a um limite de quantificação de $24 \mathrm{~nm} \mathrm{~mL} L^{-1}$ [156].

Biossensores ópticos [157], eletroquímicos [158], e fluorescentes [159] que respondem em função da atividade catalítica da enzima $\mathrm{AChE}$ foram desenvolvidos para estudos com a GAL, neostigmina e Donepezil para estudos de sensibilidade e quantificação de drogas em amostras clínicas. A imobilização da AChE no vidro porosoe o uso de um sistema de injeção em fluxo e detecção espectrofotométrica permitiu limites de detecção de $5 \times 10^{-7} \mathrm{~mol} \mathrm{~L}^{-1}$ de GAL (respondendo por $10 \%$ de inibição de AChE) [160]. Um ensaio para medições de cinética e identificação de inibidores da $\mathrm{AChE}$ foi realizado pela aplicação deespectrometria de massa acoplado ao MALDI (do inglês Matrix Assisted Laser Desorption Ionization ). A 
análise quantitativa dos níveis de colina usando a relação de colina/acetilcolina foi realizada e a concentração média inibitória $\left(\mathrm{IC}_{50}\right)$ da GAL sobre a $\mathrm{AChE}$ foi de 2,39 mol L-1 $[161]$

\subsection{3.}

\section{Atropina}

Métodos baseados na quimiluminescência [162] e na eletroquimioluminescência [163] foram desenvolvidos para a determinação de atropina, em geral em sistemas FIA. No entanto, estes métodos possuem baixa seletividade quando não combinados a métodos de separação.Já a CE, apesar de eficiente na separação, normalmente depende da detecção fotométrica por absorção, resultando em limites de detecção de $50 \mathrm{ng} \mathrm{mL}^{-1}$.[164].

Devido à suas exclusivas propriedades catalíticas e excelente condutividade elétrica e estabilidade química [165], as nanofibras de carbono têm sido amplamente utilizadas em biossensores [166]. Um método voltamétrico que utiliza eletrodos de nanotubos de carbono modificado com dodecil benzeno sulfonato de sódio foi usado para a determinaçãode atropina em sementese folhas de Datura stramonium, em alimentos para animais e em amostras biológicas (soro e urina) com um limite de detecção de $0,5 \mathrm{ngmL}^{-1}$ e faixa de trabalho a partir de $4 \mathrm{ng} \mathrm{mL}^{-1}$ [167]. Outro sensor, um eletroquimioluminescente, foi baseado em filmes compósitos de nanofibrasde carbono.As nanofibras, preparadas por eletrofiação, foram usadas para imobilizar o complexo polipiridilRu(bpy) $3^{2+}$ em filmes de Nafion® (polímero de troca iônica perfluorosulfonado) sobre a superfície de um eletrodo de pasta de carbono. A adição das nanofibras no filme compósito aumentou a corrente e a sensibilidade do sensor que mede a fluorescência do complexo de rutênio em função do potencial aplicado. A magnitude da fluorescência é afetada pela presença de atropina, permitindo o alcance do limite de detecção de $1 \times 10^{-7}$ mol L ${ }^{-1}$ para atropina em amostras de urina [168].

Diferentes métodos baseados em HPLC [169;170], na cromatografia em camada fina (TLC) [171] e no GC [172] têm sido descritos para a determinação de atropina. A técnica de HPLC-MS/MS tem se mostrado uma poderosa ferramenta analítica para a identificação de metabólitos da atropina em matrizes biológicas em fezes, urina e plasma de ratos $[173 ; 174]$. Onze metabólitos (nortropine, tropina, 
noratropine, hydroxyatropine, hydroxyatropine N-óxido, conjugados glicuronídeo e sulfato conjugados de noratropina, hidroxiatropina, e a droga parental) foram encontrados na urina de ratos. Os resultados mostraram que a principal via metabólica de atropina em ratos foi a hidrólise (tropina), N-desmetilação (noratropina e nortropina), hidroxilação (hidroxiatropina, hidroxiatropina N-óxido) e formação de sulfatos e conjugados de glicuronídeo de noratropina, hidroxiatropina, e do fármaco original [175].

Para a determinação da atropina em matrizes biológicas em estudos farmacocinéticos, além das técnicas clássicas baseadas em HPLC-UV [176], a espectrometria de massa [177] e GC-MS [178], técnicas de imunoensaio [179] e o uso de radioreceptores [180] também tem sido empregadas. A concentração sérica de atropina foi determinada tanto por ensaio utilizando radiorreceptores(RRA) quanto por radioimunoensaio (RIA). O método RIA mostrou aplicação em estudos clínicos sobre a cinéticada atropina, porém a técnica de RRA determinou a atividade antimuscarínica total, não sendo seletivo para a ação da atropina. Pequenos volumes de amostra $(25 \mu \mathrm{L}$ de soro sanguíneo) contendo em torno de $1,25 \mathrm{ng} \mathrm{mL}^{-1}$ (ou 4,33nmol L $\mathrm{L}^{-1}$ ), pode ser analisada por estes tipos de imunoensaios. As técnicas de GC-MS e HPLC-MS são as mais empregadas com faixa de trabalho entre 20-500 $\mathrm{pg} \mathrm{mL}^{-1}$. O estudo dos teores de hiosciamina e escopolamina na espécie Datura stramonium foram analisados utilizando métodos em CG-MS obtendo níveis de atropina (hiosciamina) de até 0,001 $\mu \mathrm{mg}^{-1}[181 ; 182]$.

A dosagem de atropina em urina é feita para fins de investigação sobre o uso abusivo dessas substâncias, no monitoramentode pacientes em programas de tratamento e trabalhos de toxicologia forense [183]. A estratégia analítica comum envolveuma etapainicial de triagem com imunoquímicos seguido por análise confirmatória utilizando GC-MS e HPLC-MS/MS. Por exemplo, um método forense compreendendo extração em fase sólida e análise por HPLC-MS/MS foi desenvolvido para a detecção e confirmação de atropina e escopolamina, principais alcalóides tóxicos de Datura stramonium e Datura fero. Este método baseado no uso do HPLC-MS usando ionização por electrospray foi usado para analisar amostras de vísceras humanas. A atropina e escopolamina foram detetados no conteúdo estomacal que continha sementes de Datura com limites de detecção de10 pg $\mathrm{mL}^{-1}$ para atropina [184]. 


\section{3. \\ FLUORESCÊNCIA DE PROTEÍNAS}

A fluorescência intrínseca das proteínas está relacionada à presença de grupos aromáticos em três aminoácidos triptofano (Trip), tirosina (Tir) e fenilalanina (Fen) (Figura XX) [185]. A fluorescência de cada umdeles pode ser discriminada pelos diferentes pares de comprimentos de onda $(280 / 350 \mathrm{~nm}$ para o W, 274/303 nm para a Y e 257/282 nm para a F em solução aquosa em pH fisiológico).O grupo indol do resíduo de trip é a fonte dominante de absorbância no ultravioleta e de emissão de fluorescência na estrutura das moléculas protéicas. Na prática, a fluorescência do Trip é a mais comumente estudada, visto que a Fen tem um rendimento quântico fluorescente $\left(\phi_{\mathrm{F}}\right)$ muito baixo e a fluorescência da Tir é freqüentemente muito baixa devido à sua supressão quando ionizada ou próxima de outras espécies que contenham grupos amino, carboxil ou mesmo próximo ao Trip (fenômeno de transferência de energia) [185]. Em outras situações, noentanto, elapode ser detectada com excitação em $280 \mathrm{~nm}$.

A emissão fluorescente máxima das moléculas protéicas reflete a exposição média de seus resíduos de triptofano na fase aquosa. O tempo de vida de fluorescência do Trip está em torno de 1 a 6 nse depende da presença demúltiplosresíduos deste aminoácido (cada um em um ambiente diferente). As mudanças espectrais da emissão de proteínas têm sido observada como resultado de vários fenômenos, incluindo a complexação de ligantes, a associação proteínaproteína e sua desnaturação. A emissão do Trip é altamente sensível aoambientelocale é muitas vezes usada como um grupo indicador de mudançasconformacionais dessas macromoléculas [185].

As investigações espectroscópicas levam em consideração o ambiente em torno de resíduos de Trip, o que pode fornecer informações importantes sobre a estrutura das proteínas. O padrão na distribuição de diversos resíduose a presença de outras espécies químicas em torno do resíduo de Trip são úteis na compreensão da estabilidade das proteínas, da capacidade de reconhecimento moleculare da natureza de suas ligações [186]. Apesar de relativamente poucos, os resíduos de Trip, com sua grande superfície hidrofóbica, tem um papel fundamental na estrutura 
terciária e quaternária [187;188] e nos sítios de ligação de muitas proteínas. A presença de Trip no sítio de ligação é observada em moléculas como a enzima acetilcolinesterase [189], estreptavidina [190], de miosina [191], tendo uma maior propensão de ocorrer na face extracelular das membranas protéicas [192] sendo também encontrado perto da interface lipídio-água do canal iônico formado pela gramicidina [193;194].

A aplicação mais freqüente que envolve a medição das variações de fluorescência (baseados na diferença no sinal fluorescente para os diferentes estados da proteína) estão relacionadas com estudos de transições conformacionais de proteínas, incluindo as causadas por ligações com ligantes e processos de interação proteína-proteína $[187 ; 189 ; 190]$. Esse tipo de aplicação gera informações cinéticas e termodinâmicas.

Uma abordagem muito utilizada são os estudos de supressão de fluorescência. Este fenômeno envolve qualquer processo que diminua a intensidade de fluorescência de uma amostra e que podem advir de uma variedade de interações com espécies químicas no ambienteque resultam em supressão dinâmica (colisão), rearranjos moleculares, supressão estática com formação de complexos e transferência de energia.

\subsection{1.}

\section{Aplicações da fluorescência no estudo de proteínas}

As aplicações que envolvem a medição de fluorescência têm crescido em importância e as vantagens dos métodos desenvolvidos são significativas, tornandose muito utilizados em estudos bioquímicos e de biologia molecular. A fluorescência é muito sensível ao meio onde o(s) fluoróforo(s) se encontra(m), o que é útil para obtenção de informações sobre os efeitos nas estruturas das moléculas, como mudanças na dinâmica de rotação, sobre a exposição decadeias de aminoácidosasubstâncias supressoras de fluorescência e sobre as distâncias intramoleculares. Nesse contexto, a medição da fluorescência pode ser feitas em função do tempo de decaimento de fluorescência, da concentração de agentes supressores para obter informações sobre acessibilidade aos fluoróforos, e em 
função da polarização da fluorescência de forma a se obter informações sobre o movimento de rotação da macromolécula em função das mudanças do ambiente. Tais medidas podem também ser usadas de forma combinada.

Os ensaios com uso de ligantes são empregados para reconhecimento onde as propriedades óticas do complexo proteína-analito sinaliza a presença de grupos específicos nas proteínas ou indicam a concentração do ligante presente no ambiente onde se encontra a proteína. Alternativamante, fluoróforos podem ser ligados de diferentes formas às moléculas protéicas, permitindo introduzir uma variedade de propriedades fluorescentes úteis na proteína. De fato, processos de rotina da biologia molecular já são capazes de adicionar ou excluir resíduos de triptofano em posições específicas de uma proteína modificando suas propriedades como sensores [196].

As proteínas fluorescentes, os nanocristais semicondutores ("quantum dots"), e os corantes orgânicos são amplamente usadosem ensaios com ligantes. Os fluoróforos protéicos, como a proteína verde fluorescente e suas variantes, tornaram-se muito popularesem ensaios de marcação in-vivo. Alguns trabalhos utilizam nanocristais semicondutores ("quantum dots") como indicadores ligados às proteínas para aplicações in vitro e in vivo [197]. Essas nanopartículas têm cerca de 2 a10 nm, com propriedades de fluorescência que variam com o tamanho e seu material constituinte e os rendimentos quânticos destes superam os de corantes orgânicos. As nanopartículas podem ser facilmente ligadas a grupo -SH e -NH das proteínas. No entanto, os corantes orgânicos, como os corantes Cy3 e Cy5, são ainda os mais populares fluoróforos empregados extensivamente em ensaios com DNA e proteínas.

Por questões de biossegurança e pela necessidade de ensaios mais simples em substituição ao uso de radiomarcadores, as sondas fluorescentes se tornaram amplamente atrativas em vários tipos de ensaios. Os métodos baseados no princípio da fluorescência exigem pequenas quantidades de material fluorescente e podem ser adaptados a uma variedade de configurações instrumentais desde espectrômetros com medição em cubetas ou em células de fluxo, leitores de placas, até sistemas microfluídicos. 


\section{4.}

\section{A aplicação da AChE como sonda}

Chama-se de colinesterase o grupo de $\alpha-\beta$ hidrolases que quebram eficientemente os ésteres carbônicos de colina e possuem alta afinidade para compostos com grupos positivamente carregados (amônio, fosfônio, sulfônio, etc.), e inibidores organofosforados e carbamatos. São enzimas alostéricas cuja atividade catalítica é modulada por moléculas reguladoras específicas. Os sítios de ligação desses reguladores são diferentes ds sítio catalítico da enzima. No caso das colinesterases o próprio substrato pode funcionar como modulador (enzima homotrópica). No desta proteína, o excesso de substrato inibe a própria taxa de hidrólise [198].

A molécula mais importante deste grupo, a acetilcolinesterase (AChE) exerce seu maior papel fisiológico no controle da concentração do neurotransmissor acetilcolina (ACh), que age na transmissão colinérgica. Esta função envolve as maiores características desta enzima: sua atividade catalítica excepcionalmente rápida (número de "turnover"/regeneração de hidrólise da ACh de $10^{4} \mathrm{~s}^{-1}$ [199], o mais alto relatado para catálises enzimáticas) e sua localização estratégica na sinapses colinérgicas assim como nas junções neuromusculares [200] . Após despolarização do neurônio, via abertura do canal iônico, a acetilcolina disponível é hidrolizada pela acetilcolinesterase como representado na figura 5.<smiles>CCOC(=O)CCCCC(C)=O</smiles>

Figura 6 - Degradação da acetilcolina promovida pela ação catalítica da acetilcolinesterase.

As colinesterases são conhecidas por mostrar uma marcada especificidade química que também varia de espécie para espécie de organismo. Várias colinesterases investigadas, de diferentes animais invertebrados, mostram diferenças especialmente, na sua especificidade substrato-inibidor [201]. 
Existe um grande interesse no estudo dos substratos das ChEs que é explicado pelo fato de que a $\mathrm{AChE}$ do tecido nervoso é a enzima chave na mediação da transmissão do impulso nervoso nas sinapses colinérgicas e é um alvo da ação de diferentes drogas, pesticidas e agentes de guerra química.

\section{Estrutura}

A AChE se apresenta como polímero de subunidades catalíticas, que pode assumir formas globulares ou assimétricas. As formas globulares são chamadas G1, G2 e G4, e possuem uma, duas e quatro subunidades, respectivamente. As formas assimétricas têm como subunidade de um a três tetrâmeros (A4, A8 e A12, respectivamente) ligados por pontes de dissulfeto associados a uma fita de colágeno [202], por meio da qual são fixadas à membrana basal em vários locais, como nos eritrócitos e na placa motora terminal.

O centro ativo das colinesterases está localizado no centro da molécula da enzima, perto de uma fenda estreita e profunda, formado por resíduos aromáticos, a distância de $20 \AA$ da superfície. Dois sítios funcionais foram identificados no centro ativo das colinesterases: o sítio esterásico, responsável pela ação catalítica e o sítio aniônico que liga o grupamento trimetilamônio a uma parte da molécula de colina (substrato), bem como uma área hidrofóbica ao redor desses sítios [203]. Sabe-se também que a acetilcolinesterase, diferentemente da butirilcolinesterase (outra colineterase envolvida nos mecanismos sinápticos) possui um sítio aniônico periférico responsável pela inibição da atividade da $\mathrm{AChE}$ por altas concentrações de substrato e por uma inibição acompetiva por alguns inibidores reversíveis. A determinação da estrutura tridimensional de várias ChEs e numerosos experimentos empregando mutações sítio-direcionadas de enzimas, tornou possível esclarecer mais detalhadamente as regiões das moléculas de colinesterases. Atualmente são discriminadas três regiões:

1. Tríade catalítica: o sítio esterásico contém uma tríade catalítica (Ser200, His-440 e Glu-327) que são idênticas em todas as ChEs investigadas, exceto para a AChE do ancilóstomo (platelminto) Necator americanus, cuja serina catalítica ocupa a posição 201. No gene chamado de AChE-E da espécie de peixe 
Fugu rubripes, estão ausentes um grande segmento da seqüência de Torpedo além do glutamato catalítico.

\section{A abertura/cavidade âniônica (ânion poliatômico contendo oxigênio):}

parte do sítio esterásico é também uma "cavidade" oxianiônica formado por resíduos Glu119, Trp84 e Phe330 [204] Os átomos de nitrogênio desses resíduos formam ligações de hidrogênio com oxigênios da carbonila $(\mathrm{C}=\mathrm{O})$ do substrato. O resíduo G118 e A201 são conservados em todas as ChEs investigadas, enquanto que, em algumas poucas ChEs,o Glu119 é substituído por outros resíduos [203].

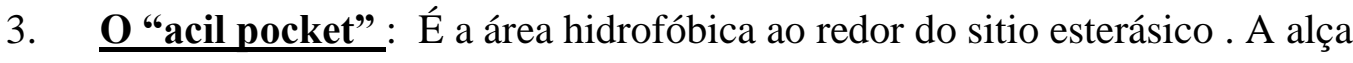
que forma esta região (resíduos 279-290) é a área que determina estericamente o tamanho disponível do grupo acila do substrato e a acilação (introdução do grupo acila) de inibidores. É consenso que a função principal desta região é desempenhada pelos resíduos Phe288 e Phe290. Esses resíduos, nas acetilcolineterases de vertebrados, são duas volumosas fenilalaninas, enquanto as butirilcolinesterases de vertebrados, em posições similares, têm resíduos com cadeias laterais menores (L288 e V 290 ou I290), que permitem ligação de substratos e inibidores com grupos acila maiores. Nas AChEs de invertebrados, como regra, existe fenilalaninas somente na posição 290.

4. O sítio caniônico (ou colina-ligante): A molécula de ACh na sua conformação completamente estendida está disposta de forma que seus grupos amônio entrem em contato com o anel indol do resíduo Trp84. Este resíduo é invariável em quase todas as ChEs . Autores como Ordentlinck [205] acreditam que existe uma interação entre os elétrons $\pi$ do anel aromático e o grupo amônio da acetilcolina. Os inibidores reversíveis também interagem com o Trp84. Sugere- se que a estrutura da "região hidrofóbica ao redor do sítio aniônico" em AChEs de vertebrados, além do Trp86 (84), incluem o "sítio hidrofóbico", que contém os resíduos Phe337 (Phe330) e Phe338. A ligação ocorre através de interações apolares e/ou interações intermoleculares aromáticas geradas por interações entre os orbitais $\pi$ das cadeias aromáticas dos resíduos de aminoácidos. Portanto, essas interações dependem da estrutura do substrato e do inibidor [203]. 
5. O sítio Aniônico periférico (PAS): este sítio da acetilcolinesterase interage com: (1) seus ligantes específicos, propidium, d-tubocurarina, galamina, ambenômio, fasciculina e alguns anticorpos monoclonais; (2) inibidores bisquaternário formando pontes entre o centro ativo e a PAS que resultam em inibição acompetitiva da enzima; (3) ativadores alostéricos da AChE: $\mathrm{Ca}^{+2}$ e o $\mathrm{Mg}^{+2}$. A PAS da AChE de mamíferos e peixes tem uma estrutura complexa e consiste de um número de sítios ligantes que estão situados perto da entrada da fenda do centro ativo. Os resíduos Asp72 e Glu199, Trp279 são identificados com uma parte comum (núcleo comum) e alguns autores incluem na estrutura da PAS os resíduos Tyr70, Tyr121, Phe290. As áreas de ligação para diferentes ligantes diferentes, porém sobrepostas. Os resíduos aromáticos da PAS interagem com ligantes por "empilhamento" ou interações $\pi$ - cátions, enquanto os resíduos negativamente carregados se ligam através de interações de carga ou por ligações de hidrogênio. A especificidade dos PAS- ligantes e dos compostos bis-amônio em relação a AChE é peculiar em comparação com as BChEs de mamíferos e da AChE de outras espécies (galinhas, cobras e insetos). Isto se explica pela ausência de um ou mais resíduos aromáticos no PAS dessas enzimas, de baixa afinidade [206].

\section{Aplicação como sonda}

Apesar do elevado número de trabalhos sobre a $\mathrm{AChE}$, incluindo os relacionados com o efeito e a localização de ligantes (inibidores) sobre sua atividade de catálise, os estudos envolvendo a exploração de suas propriedades fluorescentes são raros. O uso de fluoróforos extrínsecos é a metodologia mais utilizada para os estudos com ligantes visto que muitos inibidores não evidenciam nenhum sinal espectroscópico diferenciado após a ligação à molécula da enzima. Na química analítica, o emprego da AChE em biosensores é frequente e muitos trabalhos envolvem detecção voltamétrica e espectrofotométrica para deterninar a presença de inibidores em diferentes amostras. Os métodos analíticos baseados em fluorescência usam substratos fluorescentes para a medida de sua atividade/inibição. Na literatura encontram-se poucos trabalhos [207;208] que tiram 
vantagem da fluorescência intrínseca da enzima no desenvolvimento de metodologias para detectar espécies químicas em função das mudanças provocadas nas interações com ligantes.

Entretanto, esses poucos trabalhos sinalizam a viabilidade da aplicação da AChE como sonda para o estudo da interação com seus reguladores específicos (inibidores, ativadores e substratos). Para esse fim, algumas características particulares a AChE podem ser destacadas:

i) Apresenta estrutura com vários sítios de ligação favorecendo a interação com diferentes substâncias;

ii) Apresenta elevado número de turnover que torna os ensaios ligados à sua atividade catalítica mais rápidos;

iii) Enzima com mecanismos alostéricos de regulação que podem oferecer outras possibilidades de testes com analitos;

iv) Determinação de cinética por métodos simples;

v) Fácil obtenção;

vi) Possui fluoróforos extrínsecos específicos e bem estudados que podem ser utilizadas nos ensaios com fluorescência para detecção de analitos cuja interação com a enzima não seja evidente por sua fluorescência intrínseca.

Para fins analíticos a AChE é extensamente empregada em diferentes formatos de biossensores tendo aliado técnicas biotecnológicas para otimizar seu desempenho e ampliar suas aplicações. Entretanto, o pré-requisito para a comercialização de um biossensor é a disponibilidade de grande quantidade de material biológico extremamente puro, funcional e estável com baixo custo de produção. A enzima AChE pode ser purificada de sangue humano ou animal ou dos órgãos elétricos de enguias. Essas fontes são, entretanto, limitadas e a purificação tem alto custo e demanda de tempo.

Para contornar esse problema, as AChEs de diferentes origens tem sido clonadas e funcionalmente expressas em vários sistemas. São comuns as biossínteses de AChE de Torpedo mormata, Electrophorous electricus e de cérebro de rato, porém, esses procedimentos tem o objetivo de permitir uma análise dos mecanismos catalíticos da enzima e suas propriedades estruturais e não está voltada em atender critérios de produtividade. Os processos de biossíntese que levam a 
diferentes formas de $\mathrm{AChE}$ tem sido intensamente investigados mas apresentam baixo rendimento para fins analíticos. Isso encarece os custos de produção da enzima.

O uso desta enzima na construção de biossensores apresentam uma característica comum, inerente à própria enzima, de detectarem de forma indiscriminada a inibição provocada por todos os agentes em contato com ela. No caso em que o meio ou a amostra apresente agentes alostéricos ou ativadores da atividade enzimática esta detecção fica ainda mais complicada. Esta falta de seletividade é uma limitação de muitos métodos enzimáticos tanto no formato de biosensor como nos métodos de batelada. Para contornar este problema uma ferramenta utilizada é a aplicação dematrizesmulti-sensor (multi-enzimático, neste caso) que são combinados como processamento dos dadosdas redes neurais artificiais.

Para uma detecção multi-analito são necessárias variantesde colinesterasesgeneticamente modificadas, comconstantes de inibição alta e específicaspara cada substância. Para isso tem se recorrido à manipulação genética no desenvolvimentode sistemas de expressão de proteínas eficientes para a produçãode grandes quantidadesde enzimas recombinantes para atender suas aplicações analíticas. Pode-se obter moléculas de AChE específicas comumasensibilidade aumentadaparadiferentes inibidores através demutagênese dirigidaeser usada com sucessopara a detecção dequantidades traço inibidores emamostras complexas.

Para a purificação das enzimas são realizadas normalmente por cromatografia de troca iônica [209] e cromatografia de afinidade [210] com base na modificaçãoquímica do suporte com reversíveis inibidores da AChE[211] ousobre aadição.deumaHis-Tag à enzima [212].Para o aumento do desempenho analítico emprega-se técnicas de mutagênese sítio-direcionada após um estudo aprofundado sobre a relação entre a estrutura e o perfil catalítico da enzima. Este estudo é necessário para definir os pontos de alteração na sequencia de resíduos de aminoácidos da estrutura primária da molécula. Nesta etapa os aminoácidos sãoidentificados e avaliados segundo sua importância para a manutenção da integridade estrutural da enzima, para a catálisee para a afinidade da enzima por diferentes substratos, agentes inibidores, alostéricos e ativadores. 


\subsection{1.}

\section{Sonda fluorescente extrínseca aplicada ao estudo da AChE}

Os estudos envolvendo o efeito de ligantes e usando cristalografia de raios-X da moléculda da enizma AChE têm revelado um local ativo de cerca de $20 \AA$ de profundidade chamado de "gorge" (uma área de área de estreitamento) com cerca de dois sítios ligantes separados. Durante a hidrólise catalítica, o grupo acil do substrato(acetilcolina) é transferido rapidamente para o resíduo S2002 (de acordo com o número do resíduo em $T c A C h E$ ) no sítio de acilação. Este sítio contém resíduosenvolvidos em uma tríade catalítica (H440, E327, S200) e W84, que se liga aogrupo trimetilamônio da acetilcolina (substrato). O sítio periférico próximo à entrada do "gorge" inclui, entre outros, os resíduos D72 e W279. As investigações recentes têm demonstrado que o sítio periférico da molécula contribui para a eficiência catalítica de substratos em seu caminho parao sítio de acilação $[213 ; 214 ; 215]$.

As questões relacionadas às funções adicionais que o sítio periférico desempenha no processo catalítico tem sido de grande interesse. Foi relatado que a enzima AChE possuía dois locais distintos de ligação e que poderia haver interações entre ligantes alostéricos ligados nesses locais envolvendo mudanças conformacionais na molécula da proteína [216]. Os grupos ligados ao sítio periférico podem inibir ou acelerar reações no local da acilação, e estes efeitos têmsido muitas vezes atribuídos às interações conformacionais entre os sítios [217;218]. Porém,as evidências para tais interações conformacionais não são facilmente observadas por não apresentar alterações na estrutura do local periférico $[219 ; 220]$.

O corante benzotiazolde carga positiva tioflavina $\mathrm{T}$ (3,6-dimetil-2-(4dimethilaminofenil)-benzotiazólio) representado na figura 6 , se liga especificamente ao sítio periférico da AChE e é uma das sondas fluorescentes mais úteis já descritas para esta enzima. Este fluoróforo freqüentemente é usado para detectar massas de proteínas amilóides no cérebro de pessoas que sofrem de Mal de Alzheimer [225]. Entretanto, a estrutura tridimensional do sítio periférico da AChE não mostra nenhuma indicação da estrutura da folha beta característica da proteína $\beta$-amilóide.A fluorescência intensa de tioflavina T ligada à AChEé parcialmente 
suprimida pela ligaçãode grupos no sítio de acilação em complexos ternário, e esta supressão parece resultar deuma interação conformacional entre os dois sítios [226].

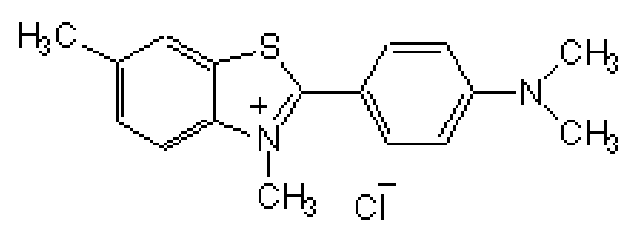

Figura 7- Fórmula estrutural da tioflavina $T$

Acredita-seque a possibilidade de rotação livre dos anéis da molécula de tioflavina T (ThT) é o que gera o aumento no seu rendimento quântico ao se ligar a fibrilas amilóides. A molécula excitada de $\mathrm{ThT}^{+}$livre,quando a rotação não é dificultada, pode sofrer uma torção de relaxamento que efetivamente concorre coma transição radiativa. Foi relatado que esta molécula tem uma conformação não planar em seu estado fundamental (não excitado), com um ângulo de torção $\varphi$ de aproximadamente $37^{\circ}$ entre os anéis benzotiazol e os anéis dimetilaminobenzeno. Quando fotoexcitado, a tioflavina $\mathrm{T}$ passa por umatransferência de carga aumentando o $\varphi$ par acerca de $90^{\circ}$ [227]. No entanto, se a tioflavinaT está localizada em um meio mais rígido, como em um solvente viscoso ou ligada a uma proteína, observou-se que a rotação interna que afeta o $\varphi$ é impedida e o rendimento quântico de fluorescência da molécula de tioflavina $\mathrm{T}$ (mais rígida) aumenta acentuadamente [228].

As propriedades fotofísicas da $\mathrm{ThT}^{+}$foram investigadas sob várias condições de solventes orgânicos em diferentes concentrações e comprimento de onda de excitação. A multifluorescencia da $\mathrm{ThT}^{+}$mostra polaridade pelo solvente e dependência de comprimento de onda de excitação. Suas bandas de emissão I (400 nm), II (450nm) e III(485nm )são observados em diferentes condições e são decorrentes de três tipos diferentes de estados eletrônicos que são devido aos estados protonados, o estado parcialmente excitado (desprotonado)e o estado dimerizados da molécula [229].Recentemente foi mostrado que o espectro de absorção da ThT é sensível à polaridade em torno de solvente, onde o pico na faixa de comprimento de onda de absorção muda de $412 \mathrm{~nm}$ na água para $424 \mathrm{~nm}$, em clorofórmio [230]. 
A tioflavina $\mathrm{T}$ é um fluoróforo que se liga seletivamente ao sítio periférico aniônico da molécula de AChE e pode aumentar sua fluorescência em até 1000 vezes comparada à tioflavina não-ligada. A estrutura do complexo da tioflavina Tcom a enzima de Torpedo (TcAChE), obtida por cristalografia de raios X,indica que oligantes e liga ao sítio-P da AChE, com o anel de benzotiazol posicionado contra o W279 [231].

Por suas propriedades, considera-sea tioflavina $\mathrm{T}$ valiosa para o estudo de interações de ligante como sítio periférico aniônico da AChE [226;231]. A tioflavina $\mathrm{T}$ tem sido usada como sonda fluorescente paradeterminar se osorganofosforados clorpirifós e diclorvós oxon se ligam ao sítio periférico aniônico da acetilcolinesterase humana recombinante. O clorpirifós oxon e diclorvos são dietil e organofosforados de dimetil, respectivamente, e não apresentam absorvância ou fluorescência significativa. Por isso a tioflavina $\mathrm{T}$ é empregada para uma avaliação da sua ligação ao sítio aniônico periférico[228].

Uma vantagem exclusiva de ligantes fluorescentes que se ligam seletivamente ao sítio-P é a sua capacidade de informar sobre as interações moleculares que ocorrem no sítio-A. A fluorescência do propídio é reforçada cerca de 10 vezes quando se liga no sítio $\mathrm{P}$, e este aumento é suficiente para realizar titulações que quantificam a afinidade do propidium pelo sítio-P e detectar a formação de seus complexos ternários ligado ao sítio-P e de ligantes seletivos como o edrofônio ligado ao sítio-A [218;232;233].Várias reações envolvendo aAChE podem ser monitoradas usando a acetiltiocolina como substrato indicador e/ou com a tioflavinaT como grupo indicador fluorescente.A fluorescência da tioflavina $\mathrm{T}$ é reforçada quandose ligaao sítio-PdaAChE,eessa fluorescênciaé parcialmente suprimida quando um segundo ligante se liga aosítio-Apara formar umcomplexo ternário. Além de monitoraro curso dareação de carbamoilação,constata-seque essas mudançasde fluorescência permitem a determinação de afinidades entre ligantes pelos sítios A e P [226].

Estudos cinéticos e termodinâmicos mostraram que os inibidorespodem interagir com um ou ambos os sítios de ligação de AChE,e a cristalografia de raio$\mathrm{X}$ tem fornecido informações sobre a localização desses sítios [234]. O "gorge" formado pelos resíduos aromáticos, penetra quase ao centro das subunidades catalíticas. Perto da base deste domínio fica o sítio de acilação ou sítio-A. Este sítio inclui uma tríade catalítica composta de resíduo Ser200, His440 e Glu327. Outras 
tríades similaressão encontradas em outras hidrolases que promovem a acilação e de acilação do resíduo de serina pelo substrato durante o ciclo catalítico (turnover) [235].

A reação de acilação foi acelerada quando uma segunda molécula de substrato é ligada ao sítio-P. As titulações com tioflavina $\mathrm{T}$ forneceram evidências para a construção deste modelo de regulação cinética. Essas titulações forneceram estimativas termodinâmicas de afinidades com o substrato para aos sítios A e P que estavam de acordo com estimativas cinética destas afinidades derivadas do modelo de ativação do substrato [235].

A extinção de fluorescência no complexo ternário ocorre mesmo que não haja sobreposição espectral (que evidencie transferência de energia), nem qualquer sobreposição estérica entre os ligantes complexados. Esta mudança na fluorescência é talvez a evidência mais direta para a interação conformacional entre os sítios P e A já observada. Os substratos específicos, incluindo acetiltiocolina são favorecidos por esta interação conformacional. Estes substratos podem se ligar tanto ao sítio A e P, como inicialmente indicado,por uma competição entre acetiltiocolina e fasciculina [235]. 


\section{2 \\ Objetivos e Justificativa}

\section{1.}

\section{Objetivos}

O objetivo deste trabalho foi propor novas sondas e formas de biorreconhecimento para a determinação de neurotoxinas (metomil, galantamina, atropina, metamidofos e metil paration) em diferentes amostras.

\section{Objetivos específicos}

1. Ampliar as aplicações analíticas das proteínas para a determinação de diferentes compostos orgânicos (pesticidas e fármacos) em diferentes matrizes ambientais;

2. Identificar novas sondas eficientes, de baixo custo e fácil obtenção a partir de frações de cérebro de ratos;

3. Avaliar o desempenho da sonda sem imobilização;

4. Realizar otimização multivariada das condições operacionais do método proposto;

5. Estudar a seletividade das interações com o analito de interesse permitindo sua aplicação em amostras complexas;

6. Comparar o método proposto com outros métodos baseados em biodetecção;

7. Caracterizar espectroscopicamenteo evento de bioreconhecimento para avaliação de sua eficiência e possíveis interferências;

8. Empregar sonda extrínseca (tioflavina T) para um estudo daestabilidade e de desempenho do biossensor imobilizado em microplacas;

9. Validar com a definição dos parâmetros de desempenho do método e comparação com métodos de referência (cromatografia líquida de alta eficiência com detecção por fotometria de absorção e de fluorescência. 


\section{2.}

\section{Justificativa}

Uma contribuição importante nos custos elevados das análises químicas é o preço dos insumos. Quando um novo método se torna muito utilizado, o preço de insumos específicos aumenta, em parte pelo aumento da procura, mas também pela importância do reagente no sucesso do método e o novo papel desse reagente na estratégia de mercado das empresas. No caso de proteínas em geral, soma-se a isso os custos envolvidos na obtenção de frações purificadas com alta atividade catalítica (enzimas). O custo da acetilcolinesterase purificada (Electrophorus electricus) com 265 unidades/mg fica em torno de $\mathrm{R} \$ 300,00$.

As demandas analíticas na área ambiental têm determinado o desenvolvimento de métodos de resposta rápida para atender normalmente ações mitigadoras ou de políticas de fiscalização. Ao mesmo tempo, as amostras ambientais apresentam uma complexidade intrínseca que têm exigido métodos mais seletivos mas que, entretanto, tenham uma implantação viável do ponto de visto econômico e operacional.

A detecção baseada na variação da fluorescência intrínseca de uma fração multiprotéica permite que novas metodologias de obtenção e de uso analítico de sondas sejam desenvolvidas baseadas em interações específicas com diferentes substâncias. Esta característica multiuso do biocomponente permite o desenvolvimento de biossensores multiparâmetros sensíveis e seletivos obtidos através de procedimentos simples e de baixo custo (sem etapas de purificação). Ao mesmo tempo, oferece possibilidades de conjugação com fluoróforos extrínsecos para potencializar e/ou adequar o método à diferentes condições operacionais.

A utilização dos ratos Wistar descartados para outros fins científicos e a redução de reagentes químicos em etapas de obtenção e purificação dos componentes protéicos agregam valores éticos à esta proposta de trabalho. 


\section{3 \\ PARTE EXPERIMENTAL}

\section{1.}

Instrumentação

Um homogeneizador T18 (IKA, São Paulo, Brasil) Ultra-Turrax ® básica e uma centrífuga Thermo Sorvall Biofuge Stratos (Thermo Scientific, Alemanha) foram usados para preparar a fração de AChE obtido a partir dotecido de cérebro de rato. As medições de fluorescência foram feitas em um espectrofotómetro de luminescência Perkin-Elmer LS-55 (Lliantrisant, UK), utilizando cubetas de quartzo com $1 \mathrm{~cm}$ de caminho óptico. As medições foram realizadas com banda espectralde passagem de $8,5 \mathrm{~nm}$ e $10 \mathrm{~nm}$, respectivamente para a excitação e emissão espectral e 500 ou $1500 \mathrm{~nm} / \mathrm{min}$ de velocidade de varredura. Os espectros de emissão foram feitos utilizando excitação a $280 \mathrm{~nm}$. Os espectros de absorção UV-Vis foram realizados em espectrofotómetro Perkin-Elmer Lambda 35. Para medições de $\mathrm{pH}$, foi empregado medidor de $\mathrm{pH}$ Tecnopon MS, modelo MPA-210 (São Paulo, Brasil). As medidas de fluorescência da Tioflavina T foram realizadas em microplaca de $8 \times 12 \mathrm{~cm}$ com 96 poços (OptiPlate F-96, preto, PerkinElmer) para as medições de fluorescência e em microplacas de poliestireno (TPP $®$, Suíça) para as medições fotométricas de cinética enzimática. As medições com microplacas foi realizada num leitor de placas PerkinElmer Victor $\mathrm{R}^{3}$ com um filtro de $405 \pm 10 \mathrm{~nm}$ para a detecção de absorção fotométrica na gama visível ou utilizando dois conjuntos de filtros: $355 \mathrm{~nm}$ (excitação) e 460 de emissão nm) para a detecção de fluorescência. A análise cromatográfica foi efectuada em um cromatógrafo Agilent Série 1200com detecção fotométrica de absorção (utilizando um detector de arranjo de díodo)edefluorescência.O delineamento experimental foi processado no Statistica 5.0 (StatSoft $®$ ) e regressão das curvas padrão foram construídas no Origin 8.0 (OriginLab. (). 


\section{2.}

\section{Reagentes}

Todas as soluções foram feitas com água ultrapura deionizada $(18,2 \mu \mathrm{S} / \mathrm{cm})$ obtida a partir de um ultrapurificadorde água Milli-Q Gradiente A10 - Millipore (Massachusetts, EUA). A atropina, iodeto de acetiltiocolina, tioflavina T, albumina de soro bovino (BSA), acetilcolinesterase (Electrophorus electricus) Tipo VIS,ácido 5,5'-ditio-bis (2-nitrobenzóico) (DTNB) e trietilamina foram adquiridos da Sigma-Aldrich (St. Louis, EUA). Obromidrato de galantamina (HBrGal) foi adquirido pela Tocris Bioscience (Ellisville, EUA) e a partir da formulação farmacêutica Reminyl ER ® (Janssen-Cilag). Os sais anidro de fosfato de sódio monobásico e dibásico foram adquiridos da Merck (Darmstadt, Alemanha). Foi utilizado acetonitrila grau HPLC (Tedia Company, Fairfield, EUA) e acetona Vetec, Rio de Janeiro, Brasil). Os compostos metamidofós e metomil foram adiquiridos da ULTRA Scientific (USA). As preparações comerciais dos agrotóxicos Lannate BR $®$ (Du Ponnt), Tamaron BR $®$ (Bayer) e Folisuper 600BR $®$ (Nufarm/Agripec) foram adquiridos em lojas epecializadas em insumos agrícolas.

As amostras e as soluções de tampões fosfato foram preparados de mistura de fosfato de sódio monobásico e sais dibásicos nas seguintes concentrações finais e os valores de pH: 0,02 e 0,05 mol L-1 (pH 6,3 e 7,5); 0,01 e 0,06 mol L-1 (pH 6,9) e $0,035 \mathrm{~mol} \mathrm{de} \mathrm{L}^{-1}$ (valores de $\mathrm{pH}$ 5,9; 7,9 e 6,9).

\section{3.}

\section{Procedimentos}

\subsection{1.}

\section{Preparação da Fração enzimática de AChE a partir de cérebro de rato}

Ratos Wistar (sacrificados com 200 dias de vida) foram doados pelo Laboratório de Neurociências e Comportamento (LANEC/PUC-Rio). Estes animais faziam parte do descarte do laboratório após a realização dos experimentos comportamentais. Dessa forma, obteve-se uma quantidade suficiente de material 
biologico fresco com um desempenho enzimático satisfatório para os ensaios com os analitos.

Os cérebros de rato foram removidos (Figura 7), lavados com água destilada $\left(4{ }^{\circ} \mathrm{C}\right)$ e secos com papel de filtro antes da remoção das meninges. Uma massa de $65 \mathrm{~g}$ de cérebro (obtido a partir de 15 animais) foram processadas em homogeneizador de tecidos com $40 \mathrm{~mL}$ de solução de sulfato de amônio a $5 \%$ e, em seguida, centrifugada a $300 \mathrm{xg}$ durante $1 \mathrm{~h} \mathrm{a} 4{ }^{\circ} \mathrm{C}$. O material sólido foi separado do sobrenadante e novamente centrifugado após a adição de mais $40 \mathrm{~mL}$ de solução de sulfato de amónio a 5\%. Ambas as frações do sobrenadante foram misturados em um frasco com tampão fosfato de sódio $0,2 \mathrm{~mol} \mathrm{~L}^{-1} \mathrm{pH}=7,4$ (volume equivalente a $1 / 4$ do volume total do sobrenadante). Dentro deste frasco, uma massa de sulfato de amónio sólido foi adicionado a fim de atingir a saturação de $30 \%$. Em seguida, a mistura foi submetida a nova centrifugação durante $20 \mathrm{~min}$. A atividade catalítica da acetilcolinesterase no "pellet" e sobrenadante foi medida o pelo método de Ellman [236] sob condições experimentais (concentração de substrato) já descritas [242].

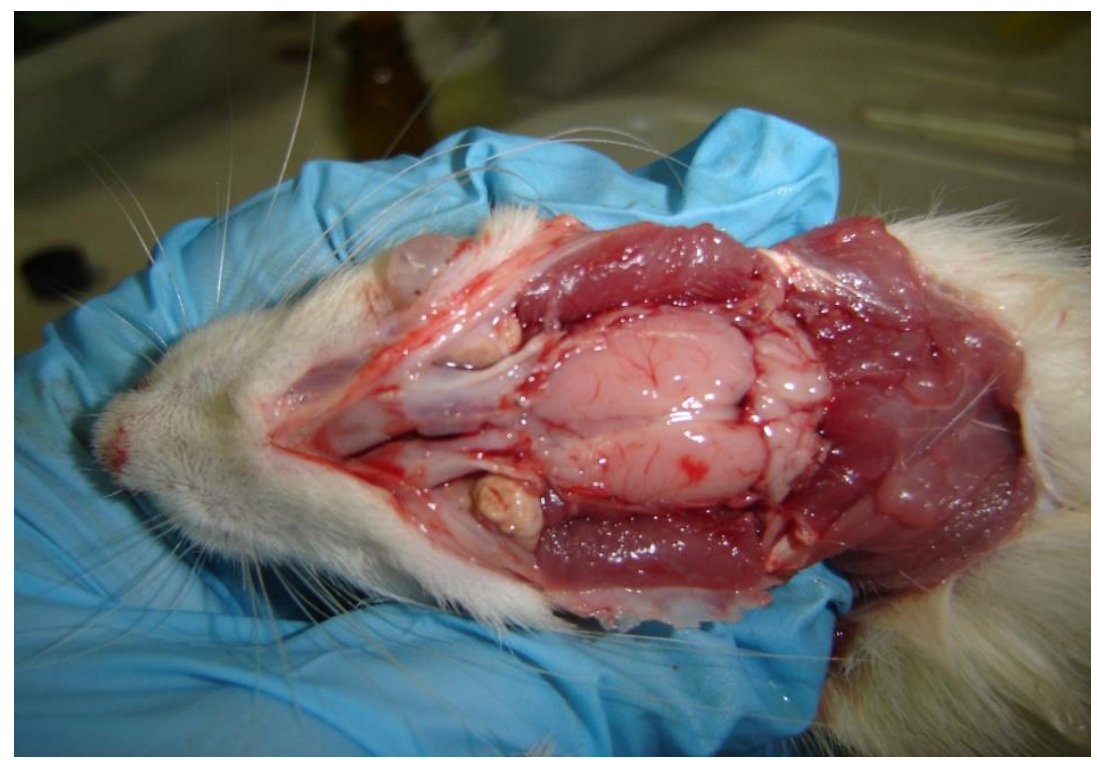

Figura 8 - Vista dorsal do cérebro de rato durante sua dissecção.

A concentração de proteína total foi determinada pelo método de Lowry modificado por Petterson [237]. Este método baseia-se na interação das proteínas com o fenol e cobre em condições alcalinas. A reação de oxidação dos aminoácidos 
aromáticos presentes pelo fosfotungístico-fosfomolibídico produz uma cor azul permitindo sua medida colorimétrica.

\subsection{2.}

\section{Otimização das condições de medição: planejamento experimental}

O objetivo do planejamento experimental foi gerar modelos matemáticos que permitissem identificar as melhores condições experimentais para a resposta de intensidade de fluorescência da sonda na presença dos analitos. Para a elaboração de métodos simples, os modelos matemáticos obtidos devem envolver variáveis significativas, porém de simples manipulação. O objetivo foi obter um modelo simples, porém eficiente de otimização.Os planejamentos das condições dos testes de cinética enzimática tiveram os seguintes objetivos: (1) correlacionar o modelo de resposta de fluorescência da fração protéica com o modelo de cinética da AChE; (2) otimizar as condições de determinação dos analitos pelo método cinético; (3) verificar a robustez do metodo cinético em sua faixa de trabalho.

Para essa etapa utilizaram-se os planejamentos tipo composto central (CCD) que estão baseados na metodologia de superfície de resposta. Os coeficientes foram obtidos utilizando o método dos quadrados mínimos e o modelo foi avaliado empregando a análise devariância. A estimativa dos erros foi alcançada através de medições de réplicas do ponto central do planejamento.

O planejamento experimental $2^{3}$ composto central foi realizado para definir as condições experimentais para as medições de fluorescência total das proteínas (figura 8).Os valores de $\mathrm{pH}$ e força iônica do tampão fosfato de sódio foram considerados fatores relevantes para otimizar ambas as medições [232;235]. A temperatura ambiente (em torno de $23{ }^{\circ} \mathrm{C}$ ) foi escolhida para os ensaios por se obter respostas sensíveis do efeito dos analitos sobre a cinética da enzima e manter a estabilidade do sistema enzima-analitos para as medidas de fluorescência. Cada parâmero foi avaliado em níveis que correspondem à faixa dos valores experimentais (Tabela 1 ). 


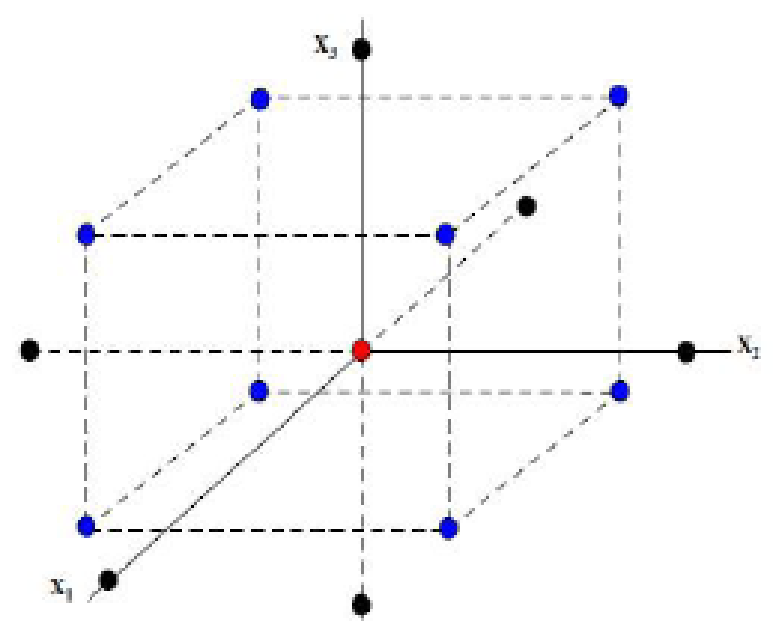

Figura 9- Esquema representativo do planejamento composto central: 8 pontos fatoriais em 2 níveis $+2 n(2 \times 3=6$ pontos axiais) +4 (pontos centrais com 3 replicatas).

Tabela 1 - Tabela com os níveis do planejamento $2^{3}$ (com pontos centrais e axiais) e os respectivos valores das variáveis reais e codificadas.

\begin{tabular}{llllll}
\hline Variáveis originais & \multicolumn{2}{l}{ Variáveis codificadas } \\
& $\mathbf{- 1 , 6 8}$ & $\mathbf{- 1}$ & $\mathbf{0}$ & $\mathbf{+ 1}$ & $\mathbf{+ 1 , 6 8}$ \\
$\mathbf{p H}$ & 5,2 & 6,3 & 6,9 & 7,5 & 7,9 \\
$\begin{array}{l}\left.\text { Força iônica (mol L } \mathbf{- 1}^{-1}\right) \\
\begin{array}{l}\text { Tempo de incubação } \\
(\mathbf{m i n})\end{array}\end{array}$ & 0,02 & 0,01 & 0,035 & 0,05 & 0,06 \\
\hline
\end{tabular}

Utilizou-se o tratamento estatístico de otimização por restrição para sobrepor as superficies de resposta aplicando a função "desejabilidade" (“desirability") para mostrar as condições experimentais com maior emissão de fluorescência do biocomponente e sua condição de maior supressão na presença dos diferentes analitos. Isso foi feito já que a sensibilidade da curva de supressão de fluorescência depende da razão entre ambas as medidas.

Para cada analito foi utilizada uma concentração fixa para os testes de otimização (fluorescência e cinética) como mostrado na Tabela 2. Tais 
concentrações foram definidas através de testes preliminares como os valores mínimos suficientes para apresentar resposta cinética e de fluorescência significativas.

Tabela 2 - Concentração dos cinco analitos utilizadas nos ensaios de otimização de fluorescência e de cinética da $\mathrm{AChE}$ presente na fração protéica.

\begin{tabular}{ccc}
\hline Analito & Cinética $\left(\boldsymbol{\mu g} \mathbf{~ L}^{-\mathbf{1}}\right)$ & Fluorescência $\left(\boldsymbol{\mu g} \mathbf{~ L}^{-\mathbf{1}}\right)$ \\
\hline Galantamina & 62,25 & 10 \\
\hline Atropina & 62,25 & 10 \\
\hline Metomil & 31,12 & 5 \\
\hline Metamidofós & 31,12 & 40 \\
\hline Metil paration & 20 & - \\
\hline
\end{tabular}

\subsection{3.}

\section{Parâmetros cineticos e inibição da atividade catalítica da AChE}

a) Parâmetros cinéticos

Um volume de 0,4 mL da suspensão de proteína (contendo $20 \mu \mathrm{L}$ da preparação protéica) em tampão de fosfato (sob a condição do pH e da força iónica definido de acordo com o desenho experimental) foi incubada com diferentes concentrações do substrato iodeto de acetiltiocolina (ATCh) para a determinação da constante de Michaelis $\left(\mathrm{K}_{\mathrm{m}}\right)$, a velocidade máxima da reação enzimática $\left(\mathrm{V}_{\mathrm{m}}\right)$, e sua atividade específica.

b) Inibição da atividade enzimática 
Os analitos (62,2 $\mu \mathrm{g} \mathrm{L}^{-1}$ de hidrobrometo de galantamina e atropina; 31,1 $\mu \mathrm{gL}^{-1}$ de metomil e $31,1 \mu \mathrm{g} \mathrm{\textrm {L } ^ { - 1 }}$ de metamidofos) foram incubados a $37^{\circ} \mathrm{C}$ com a fração protéica ( $20 \mu \mathrm{L})$ em tampão fosfato de sódio, durante 10 min (Tabela 2).

O teste de atividade enzimática foi realizado de acordo com o método de Ellman [236] adicionando o substrato acetiltiocolina (ATCh) (concentração final de $3,2 \times 10^{-4} \mathrm{~mol} \mathrm{~L}^{-1}$ ) e DTNB (concentração final de $3,2 \times 10^{-4} \mathrm{~mol} \mathrm{~L}^{-1}$ ) para a medição espectrofotométrica. Em seguida, as soluções foram imediatamente transferidas para a microplaca onde as medições de absorção fotométricas foram realizadas no leitor de microplacas durante 3 min. Este método é amplamente empregado para a determinação da atividade da acetilcolinesterase de extratos de tecidos, homogenatos e suspensões celulares. Esta medida colorimétricaem $412 \mathrm{~nm}$ relaciona o aumento da absorvância do sistema contendo a enzima com sua atividade catalítica. Este aumento é devido à reação da tiocolina (produto da hidrólize enzimática) com íons de ditiobisnitrobenzoato adicionados ao sistema reacional.

\subsection{4.}

\section{Estudos espectroscópicos preliminares: efeito filtro interno}

Para identificar e eliminar a ocorrência de efeito filtro interno nos ensaios de supressão de fluorescência realizou-se medidas das absorvâncias das suspensões dos fluoróforos (fração protéica de cérebro e AChE Electrophorus) de 0,06 mg mL-

${ }^{1}$ e de soluções dos analitos atropina $\left(1,5 \times 10^{-7} \mathrm{~mol} \mathrm{~L}^{-1}\right)$, galantamina $(2,0 \times 10-2$ mol L ${ }^{-1}$ ) e metamidofós ( $\left.2,5 \times 10^{-7} \mathrm{~mol} \mathrm{~L}^{-1}\right)$. As medidas de absorvâncias dos analitos nos comprimentos de onda de excitação ( $280 \mathrm{~nm}$ ) e emissão (345 nm) das sondas fluorescentes foram utilizadas no cálculo para a correção da resposta de fluorescência emitida após os ensaios com estes compostos.

\subsection{5.}

\section{Medição de supressão de fluorescência}

As medidas para a intensidadede fluorescência do homogenato e da $\mathrm{AChE}$ (Electrophorus electricus) foram feitas a 280/325 $\mathrm{nm}$ com $8,5 \mathrm{~nm}$ de banda 
espectral e $500 \mathrm{~nm} / \mathrm{min}$ de velocidade de varredura. A fim de medir a fração de proteína, foram utilizados $2,0 \mathrm{ml}$ de tampão fosfato de sódio $(\mathrm{pH} 7,4)$ contendo 1,0 $\mathrm{mg} \mathrm{mL} \mathrm{m}^{-1}$ de proteína total com atividade específica de $2,8 \mathrm{U} \mathrm{mg}^{-1}$. A medição da fluorescência da $\mathrm{AChE}$ (Electrophorus electricus) foi realizada com uma suspensão de $1,0 \mathrm{mg} \mathrm{L}^{-1}$ de proteína total com atividade específica de $50 \mathrm{U} \mathrm{mg}^{-1}$ em tampão de fosfato de sódio ( $\mathrm{pH} 7,4$ ) em 280/325 nm com banda espectral de $10 \mathrm{~nm}$ e 1500 $\mathrm{nm} /$ min velocidade de varredura. A titulação de ambas as suspensões protéicas foi realizada com os analitos nas concentrações apresentadas na Tabela 3.

Tabela 3 - Valores das faixas de concentrações de cada analito usada na titulação da fração protéica e da AChE purificada.

\begin{tabular}{cc}
\hline Analitos & Faixa de concentração $\left(\mathbf{m o l L}^{-\mathbf{1}}\right)$ \\
\hline Bromidrato de galantamina & $1,7 \times 10^{-8}$ à $1,0 \times 10^{-7}$ \\
Atropina & $2,0 \times 10^{-8} \mathrm{à} 1,4 \times 10^{-7}$ \\
Metomil & $2,5 \times 10^{-8}$ à $1,2 \times 10^{-7}$ \\
Metil paration & $5,0 \times 10^{-8}$ à $4,5 \times 10^{-7}$ \\
Metamidofós & $3,5 \times 10^{-8}$ à $2,5 \times 10^{-7}$ \\
\hline
\end{tabular}

\subsection{6.}

\section{Estudo do desempenho do biossensor em microplacas}

Para uma comparação entre métodos baseados em fluorescência, o comportamento de supressão da fluorescência intrínseca da AChE (280/345 nm) foi comparado ao sinal fluorescente da tioflavina $\mathrm{T}$, utilizada como sonda extrínseca (355/460 nm). Estes ensaios foram realizados em dois suportes de imobilização do sensor protéico: (i) em cubeta de quartzo e (ii) em microplaca de 96 poços. Dessa forma, pôde-se avaliar também o desempenho analítico da tioflavina $\mathrm{T}$ na determinação de ligantes específicos da $\mathrm{AChE}$ e sua aplicação como biosensor de medição em microplaca. Ao mesmo tempo, fez-se uma avaliação do desempenho da fração de enzima em microplacas de 96 poços (para seu uso como bisensor). Isto foi necessário porque o leitor de microplaca utilizado não possui monocromador e 
trabalha com filtros de corte específicos que não incluem o comprimento de onda de excitação em $280 \mathrm{~nm}$.

Preliminarmente foram feitas incubações de até 10 minutos entre as sondas AChE purificada $\left(6,3 \times 10^{-1} \mathrm{mg} \mathrm{mL}\right)$ e fração protéica $\left(2,1 \times 10^{-1} ; 4,3 \times 10^{-1}\right.$ e $6,3 \times$ $10^{-1} \mathrm{mg} \mathrm{mL}^{-1}$ ) e concentrações de tioflavina $\mathrm{T}$ de 1,0 à $5 \times 10^{-5} \mathrm{~mol} \mathrm{~L}^{-1}$ para identificar uma faixa de concentração onde pode-se observar alteração do sinal do fluorescente da tioflavina $\mathrm{T}$ na presença da enzima. A título de comparação, estes mesmos ensaios com tioflavina $\mathrm{T}$ foram realizados com solução de $8,0 \times 10^{-5} \mathrm{~mol}$ $\mathrm{L}^{-1}$ de albumina sérica bovina (BSA) em substituição às duas frações protéicas com AChE. O objetivo foi verificar a especificidade do comportamento de fluorescência observado à presença de $\mathrm{AChE}$.

A intensidade de fluorescência da solução de tioflavina $T$ foi medida após seu uso com agente titulante da fração proteíca complexada aos compostos metomil (AChE-Me) e metamidofós ((AChE-Met).Este ensaio foi realizado em cubeta de quartzo e em microplaca de poliestireno de 16 poços.

Tabela 4 - Faixa das concentrações dos analitos para a titulação com a fração protéica e a tioflavina $T$.

\begin{tabular}{cc}
\hline Analitos & Faixa de concentração $\left(\mathbf{m o l L}^{-1}\right)$ \\
\hline Metomil & $5,0 \times 10^{-8}$ à $2,0 \times 10^{-7}$ \\
\hline Metamidofos & $2,0 \times 10^{-8}$ à $1,8 \times 10^{-7}$ \\
\hline
\end{tabular}

As medições de fluorescência foram realizadas com $0,4 \mathrm{~mL}$ de soluções e de cada medição foi realizada em 0,1 s em microplacas de 96 poços (Figura 9). 


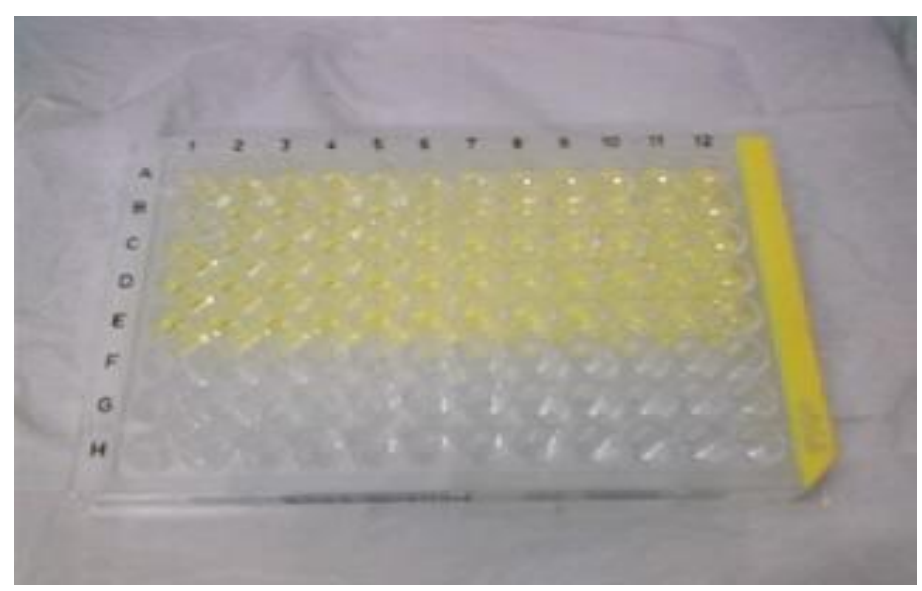

Figura 10 - Foto da microplaca com as incubações enzimáticas com adição de substrato e reativo de cor.

\subsection{7.}

\section{Coleta e tratamento das amostras de solo}

\subsubsection{1.} Coleta

As amostras de solo foram coletadas em área agrícola do município de Nova Friburgo (RJ) segundo metodologia de coleta de solo [240].Na chegada ao laboratório, o material foi seco ao ar e peneirado em malha de $2 \mathrm{~mm}$ [241].Para a obtenção de amostras consideradas sem contaminação por pesticidas anticolinérgicos, foram coletadas amostras de solo em área de mata sob vegetação densa, sem histórico de utilização antrópica e afastada de áreas de influência da deriva dos produtos aplicados. O objetivo era realizardeterminações em amostras de solo da camada arável $(0$ a10 cm) atingida por aplicações de agrotóxicos e influenciada pelo manejofísico-químico do solo (possibilidade de interferências de matriz). 


\subsubsection{2.}

\section{Caracterização do Solo}

As amostras de solo foram caracterizadas nos seguintes parâmetros:

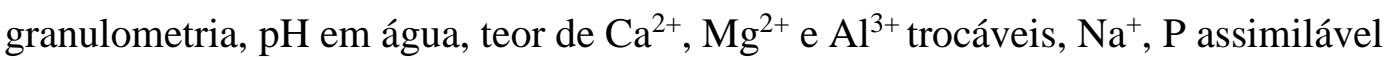
, $\mathrm{K}^{+}, \mathrm{C}$ (orgânico). Estas análises foram feitas na Embrapa SOLOS (RJ).

\subsubsection{3.}

\section{Fortificação e extração}

A fortificação e extração das amostras foi realizada em acetona segundo procedimento já otimizado [242]. As amostras de solos foram fortificadas para obtenção de uma concentração final de $1 \mathrm{mg} \mathrm{kg}^{-1}$. Massas de $40 \mathrm{~g}$ de solo foram homogeneizadas com $20 \mathrm{~mL}$ de solução de Lannate BR; Tamaron e Folisuper 600BR na concentração de $2 \mathrm{mg} \mathrm{L}^{-1}$ cada um em acetona. Foram utilizadas soluções comerciais para avaliar o efeito dos ingredientes inertes presentes nestas formulações a saber: Lannate $-78,5 \% \mathrm{~m} / \mathrm{v}$; Tamaron $-58,0 \% \mathrm{~m} / \mathrm{v}$ e Folisuper $52,8 \% \mathrm{~m} / \mathrm{v}$.

Após o período estabelecido de $1 \mathrm{~h}$ para a adsorção do pesticida à matriz, o solvente foi evaporado completamente com fluxo de ar contínuo e retiradas 3 subamostras de $10 \mathrm{~g}$ cada para posterior extração dos agrotóxicos. Posteriormente, os extratos de solo foram evaporados ao volume final de $2 \mathrm{~mL}$ e a detecção dos analitos feita a partir da incubação do extrato seco com a fração de acetilcolinesterase em tampão fosfato $\mathrm{pH}=7.5$.

\subsection{8.}

\section{Validação}

\subsubsection{1. Determinações por fluorescência e cromatografia líquida}

As curvas analíticas de fluorescência foram construídas com a fração protéica obtida do cérebro de rato. As curvas de supressão de fluorescência foram realizadaspor titulaçãoda suspensão deproteína comos analitos.A precisão dométodo foi avaliadaatravés da medição de amostras fortificadas (urina e solo) 
com cada analito: Nas amostras de urina foram usadas as concentrações de GAL e atropina (ambas de 5,6 x 10 $\left.0^{-6} \mathrm{~mol} \mathrm{~L}^{-1}\right)$; metomil $\left(8,0 \times 10^{-6} \mathrm{molL}^{-1}\right)$; metil paration $\left(3,0 \times 10^{-6} \mathrm{~mol} \mathrm{~L}^{-1}\right)$ e metamidofós $\left(1,2 \times 10^{-5} \mathrm{~mol} \mathrm{~L}^{-1}\right)$.A escolha das concentracões de cada analito se baseou nos estudos de farmacocinética e nos teores encontrados em amostras ambientais. As amostras de solo foram fortificadas com $1 \mathrm{mgKg}^{-1}$ da cada um dos três agrotóxicos (metomil, metil paration e metamidofós).

Alíquotas de $100 \mu \mathrm{L}$ de amostras de urina(fresca) foram adicionadas a $2,5 \mathrm{ml}$ de suspensãode proteína para a medição direta da sua emissão de fluorescência a 280/345 nm.Não houve etapa de limpeza da amostra. Os resultados foram comparadoscom análises emcromatografia líquida.

Para a análise cromatográfica de amostras de urina foi utilizada uma coluna

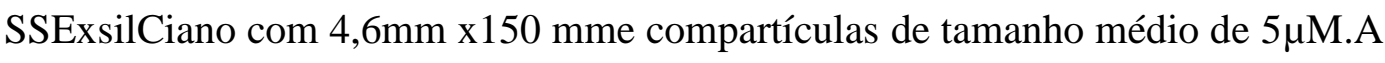
fase móvel consistiude acetonitrila(A) e água com trietilaminaa 2,5\% $(\mathrm{pH}<3,5)$ (B).O programa de gradiente de eluição, a uma taxa de fluxo de $0,6 \mathrm{mLmin}^{-1}$, foi 1,5min com $100 \%$ de B, seguido da diminuição de Bde 100 para 90\% em 0,5 min,mantendo $90 \%$ de Bde 2 a80 min de corrida.A colunamantida aumatemperatura de $25^{\circ} \mathrm{C}$,como detector de fluorescência foi ajustado para 240/340nme com detector de DAD ajustado com comprimentos de onda de 260, 240, 320, $360 \mathrm{~nm}$ para gerar um cromatograma tridimensional.A fase móvel para as amostras de urina foi composta por tampão fosfato $\mathrm{pH}$ 5,5 (hidrogenofosfato dissódico $\mathrm{Na}_{2} \mathrm{HPO}_{4} 10$ mmol L-1/ácidofosfórico):2-propanol:trietilamina(95:5:0,5, $\mathrm{v} / \mathrm{v} / \mathrm{v})$.

\subsubsection{2.}

\section{Parâmetros de desempenho analítico}

Os procedimentos para validação do método proposto seguiram a orientação do INMETRO (Instituto Nacional de Metrologia, Qualidade e Tecnologia) para ensaios químicos [239]. Os parâmetros de desempenho foram calculados a partir dos valores desete medidas independentes do branco (para o cálculo de LD) e de mais sete amostras para o cálculo do LQ. O LD foi calculado segundo a fórmula (1):

$$
\mathrm{LD}=\mathrm{M}+3\left(\mathrm{~s}_{\mathrm{b}}\right)
$$


Onde "M" é a média das concentrações das replicatas do branco das amostras e "sb" é a estimativa do desvio padrão das sete replicatas do ensaio em branco.

Para o cálculo do LQ foi aplicada a fórmula (2) apresentada abaixo considerando as medidas de sete amostras independentes.

$$
\mathrm{LQ}=M+10 \mathrm{~s}(2)
$$

Onde " $M$ " é a média das concentrações das replicatas do branco das amostras e sb o seu respectivo desvio padrão.

Para o cálculo da precisão do método (repetitividade e reprodutibilidade) foi utilizada a concentração de $6,0 \times 10^{-8} \mathrm{molL}^{-1}$ para Gal, atropina, metomil e metamidofós e $1,20 \times 10^{-6} \mathrm{molL}^{-1}$ para metil paration. A repetitividade e a reprodutibilidade foram expressas como desvio padrão relativo (\%RSD). Para a repetitividade, que mede a dispersão dos valores de medições sucessivas sob as mesmas condições, o cálculo aplicado está representado na equação (3).

$$
\operatorname{RSD}(\%)=\left(s_{\mathrm{r}} / \mathrm{M}_{\text {medição }}\right) \times 100(3)
$$

Onde $s_{\mathrm{r}}$ é a estimativa do desvio padrão de dez replicatas e M é a sua média.

Para o cálculo da reprodutibilidade foi aplicado o teste de hipótese aos dois conjuntos de medidas sucessivas feitas em dois equipamentos diferentes. $\mathrm{O}$ valor calculado foi comparado com o valor tabelado na distribuição $t$ deStudent para comprovar a igualdade estatística de ambos os conjuntos de medidas. Para o cálculo da reprodutibilidade foi utilizada a soma dos quadrados dos desvios de repetitividade (dentro de cada grupo) e entre o conjunto de medidas de cada equipamento (entre grupos). A reprodutibilidade $\left(s_{R}^{2}\right)$ foi calculada segundo a equação (4):

$$
\mathrm{S}^{2}{ }_{\mathrm{R}}=\left(\mathrm{s}_{\mathrm{r}}^{2}+\mathrm{s}_{\text {entre }}^{2}\right)(4)
$$


onde:

$\mathrm{s}^{2}{ }_{\text {entre }}=\left(\mathrm{MQ}_{\text {entre }}-\mathrm{MQ}_{\text {dentro }}\right) / n$

$\mathrm{s}^{2}{ }_{\mathrm{r}}=\mathrm{MQ}$ dentro

$\mathrm{O}$ valor $\mathrm{s}_{\mathrm{R}}^{2}$ é a soma dos quadrados dos desvios da repetitividade entre os equipamentos, "MQentre" é a soma dos míninos quadrados entre os equipamentos e "MQdentro" é a soma dos mínimos quadrados de cada equipamento.

Os ensaios de recuperação foram realizados com amostras fortificadas com soluções dos analitos (galantamina e atropina) e, para solos, com soluções comerciais dos agrotóxicos metomil (Lannate®- DuPont), metamidofós (Tamaron ( - Bayer) e metil paration (Folidol ${ }^{\circledR}$ - Bayer). As amostras de solo foram fortificadas como descrito no item 3.3.7.3 e as amostras de urina fresca (10 mL) foram fortificadas com os analitos: atropina, galatamina (ambos a 5,6 x 10 $0^{-6} \mathrm{~mol} \mathrm{~L}$ $\left.{ }^{1}\right)$, metomil $\left(8,0 \times 10^{-6} \mathrm{~mol} \mathrm{~L}^{-1}\right)$, metamidofós $\left(1,2 \times 10^{-5} \mathrm{~mol} \mathrm{~L}^{-1}\right)$ e metil paration $\left(3,0 \times 10^{-6} \mathrm{~mol} \mathrm{~L}^{-1}\right)$. O cálculo da porcentagem de recuperação comparou as determinações obtidas pelo método proposto e pelo de referência (HPLC) com os valores esperados (concentrações de fortificação). 


\section{4 \\ Resultados}

\section{1. Preparação da Fração protéica a partir de cérebro de rato}

O objetivo de extrair a fração proteíca a partir do cérebro de rato foi obter um material multiprotéico para detecção de compostos neurotóxicos explorando suas interações específicas proteína-analito.Para isso a intenção era obter um material biológico que contenha sondas específicas para seu biorreconhecimento e e que atendendam as exigências de sensibilidade de ensaios analíticos. A obtenção desse material deve envolver um procedimento simples e o material obtido deve ser conservavel para uso posterior. Ao mesmo tempo,o materialdeve conter elementos de bioreconhecimento com certa especificidade aos analitos do estudo.O extrato protéico obtido manteve frações significativas da enzima $\mathrm{AChE}$ e de proteínas estruturais como os neuroreceptores como mostrou os testes de afinidade com os analitos.

Para os testes de fluorescência usando o extrato protéico do cérebro de rato evitou-se o uso de detergentes como o Triton X-100, muito usados para solubilizar a fração enzimática particulada ligada à membrana. Apesar desta fração ter um desempenho cinético adequado, foram observados frequentes problemas de interferências no sinal de fluorescência da fração particulada solubilizada nestes detergente causadas por impurezas.

A forma como se apresenta a AChE pode afetar sua atividade aparente sob certa condições de ensaio.Esta atividade aparente é considerada aqui como o incremento da absorvância da solução de acetiltiocolina $(412 \mathrm{~nm})$ por minuto devido à sua hidrólise pela ação da enzima AChE. Portanto ela corresponde à atividade catalítica da enzima expressa em U (unidade de atividade enzimática).

As diferenças na atividade entre a forma solúvel e particulada da enzima resultam em algumas mudanças intrínsecas originadas de uma alteração na estrutura terciária da proteína . A Permeabilidade da membrana com barreiras ao livre acesso 
e livre difusão do substrato e demais ligantes pode afetar sua resposta analítica como sonda.Alguns ensaios mostram que as determinações da atividade da fração particulada são menos precisas do que a atividade da fração solúvel. Estas barreiras são reportadas em homogenatos de enguiaem testes com um substrato lipossolúvel, o acetato de indofenil [244]. Este substrato, mais permeável à membrana, produziu a mesma atividade relativa para a enzima solúvel e a particulada sob condições de tamponamento.

A fração "salt soluble" da AChEfoi definida operacionalmente como aenzima extraída de tecido na ausência de detergente.Neste procedimento de extração pretendeu obter uma fração sobrenadante solúvel em sulfato de amônio (fração solúvel em sal). O procedimento de extração procurou manter, apesar de eliminar grande parte da fase lipídica no 'pellet', uma parte dos receptores de membrana, seguindo outros protocolos utilizados para a extração de neuroreceptores em tecidos [245;246;247;248].

A Tabela 5 mostra o rendimento da extração após as duas primeiras etapas de centrifugação do homogenato de cérebro de rato. A fração I se refere ao extrato após a segunda centrifugação e a fração II se refere à fração final (após a precipitação com sulfato de amônio). Considerando a atividade específica de 1300 $\mu \mathrm{mol} \mathrm{min}{ }^{-1} \mathrm{mg}^{-1}$ com uma massa de proteína total de $22,4 \mathrm{mg} \mathrm{mL}^{-1}$ (fração I), a fração II apresentou perda de atividade específica de aproximadamente $30 \%$ e a massa de proteína total eliminada da fração foi de $22 \%$.

Tabela 5 - Tabela com o rendimento da extração indicando a perda de atividade específica da AChE na a obtenção da fração protéica final.

\section{Fração $\quad$ Proteína total $\left(\mathrm{mg} \mathrm{mL}^{-1}\right) \quad$ Atividade específica $\left(\mathrm{U} \mathrm{mg}^{-1}\right)$}

\begin{tabular}{ccc}
\hline I & 22,4 & 1300 \\
\hline II & 5 & 943 \\
\hline
\end{tabular}

Este protocolo otimizado teve por base outros procedimentos de fracionamento de tecido cerebral de ratocapaz de promover a transformação dos organofosforados em suas formas oxon responsáveis pela inibição da AChE [249]. 
Assim seria possível incluir os organofosforados (metamidofós e metil paration) como analitos.

Pelo fato da enzima estar solubilizada eligada à membrana, é natural que se encontremdiferenças nasenzimas presentes em preparações subfracionadas de extratos/homogenatosjá que mudanças conformacionais nas enzimas ocorrem durante os procedimentos de extração e purificação [244]. Múltiplas formas ativasda acetilcolinesterase cerebral de ratos foram encontradas segundo Adamson e colaboradores [250]. As seis formas observadas são semelhantes em vários aspectos (subunidades, peso molecular, características de glicoproteínas e ponto isoelétrico) [251]. Além disso, as propriedades estruturais finais das diferentes formas também são inerentes ao processo de extração e purificação empregados. As isoenzimas (alfa e beta) da Nucleosídeos Difosfato Quinases (NDP quinases) contêmos mesmotrêsresíduos de triptofano (Trp78, 133, Ind149) e quatro tirosinas (Tyr 52, 67, 147, e 151) por subunidade, mas apresentam diferençasacentuadasnas suas propriedades de fluorescência (tanto em posições espectrais e forma e valores de rendimento quântico) e se comportamde forma diferente em função do $\mathrm{pH}$ [251]. Por estas razões a comparação do material extraído com o padrão comercial de AChE purificado (Electrophorus electricus) deve ser feita com cuidado.

\subsection{1. Caracterização cinética}

A definição dos parâmetros cinéticos de uma enzima específica são importantes para se conhecer seu mecanismo catalítico. Do ponto de vista analítico (identificação e avaliação de sondas enzimáticas), estes parâmetros são importantes para: (1) definir as condições experimentais adequadas para os ensaios enzimáticos (concentração ideal de substrato e inibidores, tempo de reação, etc); (2) identificação de algum tipo de regulação alostérica como a inibição por excesso de substrato já bem descrita para a AChE; (3) tipos de mecanismos de inibição ou ativação; (3) definição de constantes de equilíbriode Michaelis $\left(\mathrm{K}_{\mathrm{m}}\right)$. Neste caso, o valor de $\mathrm{K}_{\mathrm{m}}$ daAChE será útil para comparações com as constantes de associação 
$\left(\mathrm{K}_{\mathrm{a}}\right)$ nos ensaios de fluorescência para descrever as interações da fração protéica com os ligantes (analitos).

A fração da AChE (solúvel em sal- fração II) presente na fração protéica foi caracterizada segundo seus parâmetros cinéticos $K_{m}$ e $V_{\text {máxima que foram }}$ respectivamente $0,4 \mathrm{mmol} \mathrm{L}^{-1}$ e a $\mathrm{V}_{\text {máxima }} \mathrm{em} \mathrm{1,0} \mathrm{mmol} \mathrm{min}^{-1} \mathrm{mg}_{\text {proteína }}{ }^{-1}$. Esses valores mostram a afinidade da $\mathrm{AChE}$ presente pelo substrato utilizado nos testes (acetiltiocolina), expressa por $\mathrm{K}_{\mathrm{m}}$ e a eficiência em sua hidrólise, representada por $\mathrm{V}_{\text {máxima. }} \mathrm{O}$ material protéico obtido do cérebro de rato, apesar de um procedimento simples de fracionamento, alcançou um perfil cinético satisfatório quando comparado às frações de $\mathrm{AChE}$ solúvel de mesma origem caracterizadas na literatura [252]. Pode-se considerar que o substrato utilizado nos ensaios cinéticos possui afinidade à molécula de $\mathrm{AChE}$ da fração suficiente para compor ensaios com resposta cinética rápida e sensível exigida para sensores analiticos.

\section{2. Otimização das condições de complexação: planejamento experimental}

A metodologia de superfície de resposta se baseia na construção de modelos matemáticos empíricos que geralmente empregamfunções polinomiais (lineares ou quadráticas). Assim, esses planejamentos oferecem condições de explorar o sistema até se obter as condições ótimas.Os resultados de um planejamentoexperimentaldevem indicar o conjunto de fatores significativos para se ajustar o modelo empírico que representa a relação existente entre esses fatores e a resposta de fluorescência das proteínas.

Neste trabalho foi adotado o planejamento Composto Central "CCD Central Composite Design, um dos tipos de planejamentos mais utilizados paraajustar modelos quadráticos. Este planejamento inclui a medição de réplicas no centro do desenho (valor médiodos níveis de todas as variáveis) que permite avaliara significância dos efeitos ou coeficientes. Além disso, recomenda-se este tipo de experimento para se estimar um modelo razoável, com a verificação da falta de ajuste e minimização do risco de perder a relação não-linear entre as variáveis [248]. 


\subsection{1.}

\section{Fração protéica (controles)}

Antes dos testes com os analitos realizou-se planejamentos somente com a fração protéica (biocomponente) de modo a gerar superfícies de resposta dos respectivos modelos (fluorescência e atividade enzimática da AChE). Em seguida realizou-se a sobreposição destas representações do modelo do biocomponente (controle) com o modelo na presença de cada analito estudado. A importância da sobreposição dos domínios das respostas nos dois modelos obtidos é que isso permite encontrar uma condição otimizada avaliando-se simultaneamente, as condições iniciais (sem analito) e finais (com o analito).

Para o evento de supressão defluorescência, a condição ótima para a maior sensibilidade analítica seria a de maior sinal do controle (biocomponente sem analito ou $F_{0}$ ) e menor fluorescência na presença do analito $(F)$. A medida de supressão de fluorescência considera a razão $\mathrm{F}_{0} / \mathrm{F}$ e, dessa forma, chega-se a uma maior sensibilidade das curvas de supressão. Para a cinética, de forma semelhante, a condição ótima é a de maior atividade da AChE (controle) e a menor atividade na presença do analito (ou seja, maior inibição).

\subsubsection{1. \\ Fluorescência}

\section{Estudo das interações}

A Figura 10 apresenta o gráfico de Pareto que indica a análise da significância de cada variável na resposta intensidade de fluorescênciada fração protéica. Este gráfico mostra cada um dos efeitos calculados em ordem decrescente de magnitude. O comprimento de cada barra é proporcional ao efeito padronizado (efeito é calculado dividindo o efeito pelo desvio-padrão). A linha vertical pode ser usada para julgar quais efeitos são estatisticamente significativos. Qualquer barra que se estenda além da linha corresponde a um efeito significativo ao nível de $95 \%$.

Para a intensidade de fluorescência total da fração de cérebro de rato, os efeitos principais (de dimensão quadrática) dos três fatores estudados (força iônica, 
pH e tempo de incubação) foram significativos ( $95 \%$ de confiança). O gráfico de Pareto também mostra que as interações entre os fatores não tiveram efeito importante para o valor da fluorescência. Os valores positivos dos efeitos indicam que um aumento das variáveis implicará em aumento do sinal da resposta (para a faixa experimental compreendida nos níveis do planejamento).

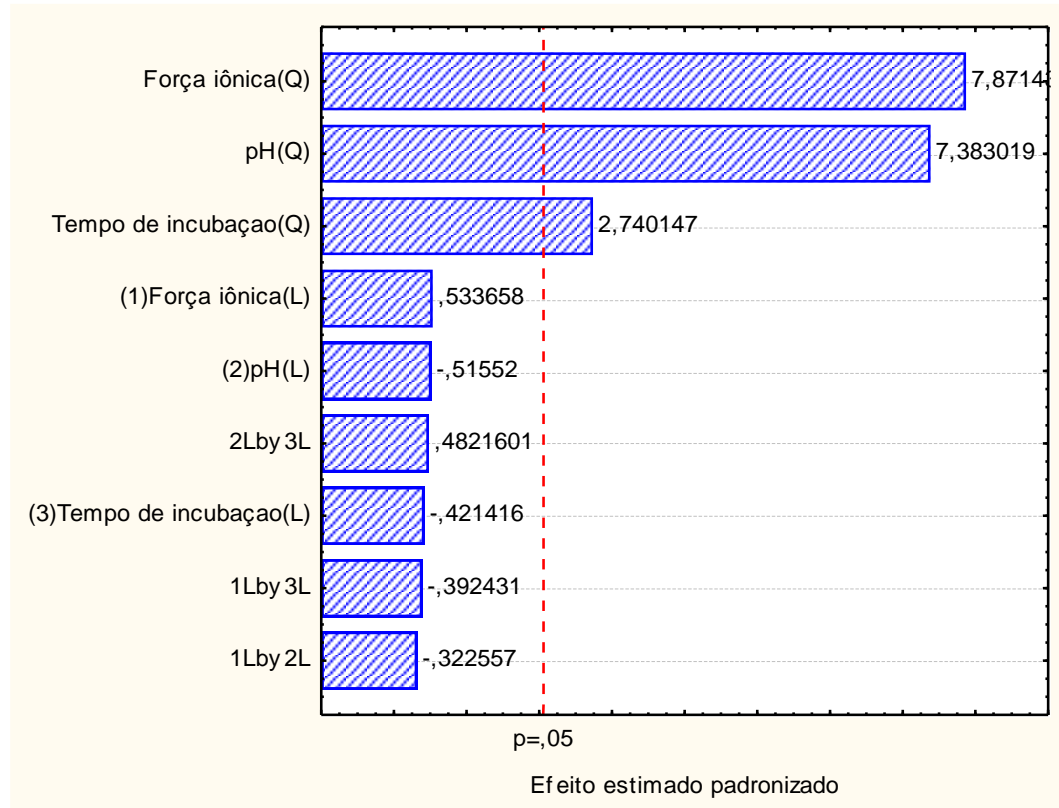

Figura 11- Gráfico de Pareto indicando os efeitos estatisticamente significativos para o desenho experimental aplicado mostrando a importância dos 3 fatores escolhidos para o estudo.

\section{$\underline{\text { Avaliacão do modelo (ajuste) }}$}

Pode-se assumir que o sistema estudado é regido por alguma função que édescrita pelas variáveis experimentais. Normalmente esta função podeser aproximada por um polinômio, o qual pode fornecer uma boa descriçãoda relação entre os fatores e a resposta obtida. Como a ordem deste polinômio élimitada pelo tipo de planejamento usado, os planejamentos fatoriais de dois níveis podem estimar apenas efeitosprincipais e interações. Por isso optou-se pelo planejamento fatorial de três níveis (ponto central) para poderincluir a estimativa do grau de curvatura do modelo. 
O modelo obtido pode não ser exatamente aquele que descreve a região estudada do sistema e, neste caso, não pode ser usado para fazer estimativas e muito menos para extrair conclusões sobre a região ótima. A maneira mais confiável de se avaliar a qualidade do ajuste do modelo é empregando a análise devariância (ANOVA). Por isso, um bom modelo necessita ter uma regressãosignificativa e uma falta de ajuste não significativa. Isto significa que a maior parte da variação total das observações emtorno da média deve ser descrita pela equação de regressão e orestante certamente ficará com os resíduos. Idealmente amaior parte da variação embutida nos resíduos deve ser fruto do erro experimental (erropuro) e não com a falta de ajuste do modelo. Outros parâmetros para observar se toda variação em torno da média foi explicada pela regressão são o valor do coeficiente devariação $\mathrm{R}^{2}$ e o gráfico dos resíduos.

A análise da variância usa as médias quadráticas (MQ) para testar se a equação de regressão é estatisticamente significativa. Com isso, verifica-se o grau de ajuste do modelo pela comparação da razão $\mathrm{MQ}_{\mathrm{R}} / \mathrm{MQ}_{\mathrm{r}}$ ao $\mathrm{F}$ crítico correspondente aos graus de liberdade obtidos (graus de liberdade da média quadrática devida à regressão, $M Q_{R}$,e da média quadrática residual, $M Q_{\mathrm{r}}$ ), devendo esta razão ser maior do que o valor de $\mathrm{F}$ crítico. Neste caso, o valor de $M Q_{R} / M$ foi 10,84 , que, por sua vez, foi maior do que o valor para $\mathrm{F}$ calculadoo que indica que o modelo de regressão é estatisticamente significativo.

Para se avaliar a parte da variação explicada pela falta de ajuste do modelocompara-se a razão $\mathrm{MQ}_{\mathrm{faj}} / \mathrm{MQ}_{\mathrm{ep}}$ ao $\mathrm{F}$ crítico correspondente, onde $\mathrm{MQ}_{\mathrm{faj}}$ é a média quadrática da falta de ajuste e o $\mathrm{MQ}_{\mathrm{ep}}$ é a média quadrática do erro puro. Para não haver falta de ajuste, o valor da razão deve ser menor que o valor de F. Neste caso, a razão $(2,46)$ é menor que o valor de $\mathrm{F}$ tabelado e, portanto o modelo proposto não apresenta falta de ajuste com so dados experimentais.

A porcentagem de variação explicada pela regressão, isto é, a razão entre a soma quadrática devida à regressão $\left(\mathrm{SQ}_{\mathrm{R}}\right)$ e a soma quadrática total $\left(\mathrm{SQ}_{\mathrm{t}}\right)$ é igual ao coeficiente de determinação, $\mathrm{R}^{2}$, que no caso foi 0,79 . Esse valor porém, não deve ser comparado com $100 \%$, por causa da contribuição devida ao erro puro. O valor máximo explicável é a diferença entre a soma quadrática total $\left(\mathrm{SQ}_{\mathrm{t}}\right)$ e a soma quadrática do erro puro $\left(\mathrm{SQ}_{\mathrm{ep}}\right)$. Neste caso, $\mathrm{SQ}_{\mathrm{T}}-\mathrm{SQ}_{\mathrm{ep}}=772666,9-102523,8=$ 670143,1. Assim, o valor dessa diferença e o valor de $\mathrm{SQ}_{\mathrm{t}}(670143,1 / 772666,9)$ é 0,867 , ou seja, $86,7 \%$ da soma quadrática total, que éo valor que deve ser usado 
para comparar a variação explicada pela regressão. $\mathrm{O}$ valor de $\mathrm{F}_{9,26}$ calculado de 2,27 (no nível de 95\%) indica que o um modelo de regressão é significativo visto que o valor da razão $M Q_{R} / M_{\text {r }}$ igual a 10,84 é maior que o valor de $\mathrm{F}_{9,26}$ tabelado.

Para este caso, os dados da tabela ANOVA (Tabela 6) mostram que a fração da variação dos dados explicável pela regressão é de $87 \%$. Dessa variação explicável, o modelo de regressão proposto explica uma importante porção da variação dos dados, 79\%. Como não existe falta de ajuste significativa do modelo podemos considerar esta regressão válida para otimizar as condições de fluorescência da fração protéica extraída do cérebro de rato (Figura 11).

Tabela 6 - Resultado da análise de ANOVA do modelo de regressão.

\begin{tabular}{clll}
\hline $\begin{array}{c}\text { Fonte de } \\
\text { Variação }\end{array}$ & SQ & Gl & MQ \\
\hline Regressão & 610108,0 & 9 & 67789,78 \\
Resíduo & 162558,8 & 26 & 6252,262 \\
Falta de ajuste & 60035,1 & 12007,0 \\
Erro puro & 102523,8 & 35 & 4882,1 \\
Total & 772666,9 & & \\
\hline $\begin{array}{c}\text { \% variação } \\
\text { explicável } \\
\text { \% de variação } \\
\text { explicada pela } \\
\text { regressão }\end{array}$ & 86,7 & & \\
\hline
\end{tabular}

A resposta do controle, modelada pela regressão, mostra um ponto de mínimo de 236 unidades arbitrárias de fluorescência (u.a). Os maiores valores de fluorescência do material protéico ficaram restritos às arestas da superfície de resposta. Isso mostra que a faixa experimental escolhida não compreende as condições para se obter os valores mais altos de intensidade, o que aumentaria a sensibilidade das curvas de supressão. Nesse sentido uma superfície com um ponto de máximo seria o ideal. Entretanto, como a resposta depende primordialmente da ocorrência de interação (evento de biorreconhecimento sonda-analito), algumas considerações são importantes: (1) os maiores valores de fluorescência inicial $\left(\mathrm{F}_{0}\right)$ 
podem não ser favoráveis à interação com os analitos; (2) uma intensa fluorescêcia de proteínas totais pode tornar a supressão menos evidente (menor sensibilidade do evento). Além disso, a faixa utilizada neste planejamento está de acordo com as condições de inibição da AChE [249] que compõe esta fração e tem alta afinidade pelos analitos.

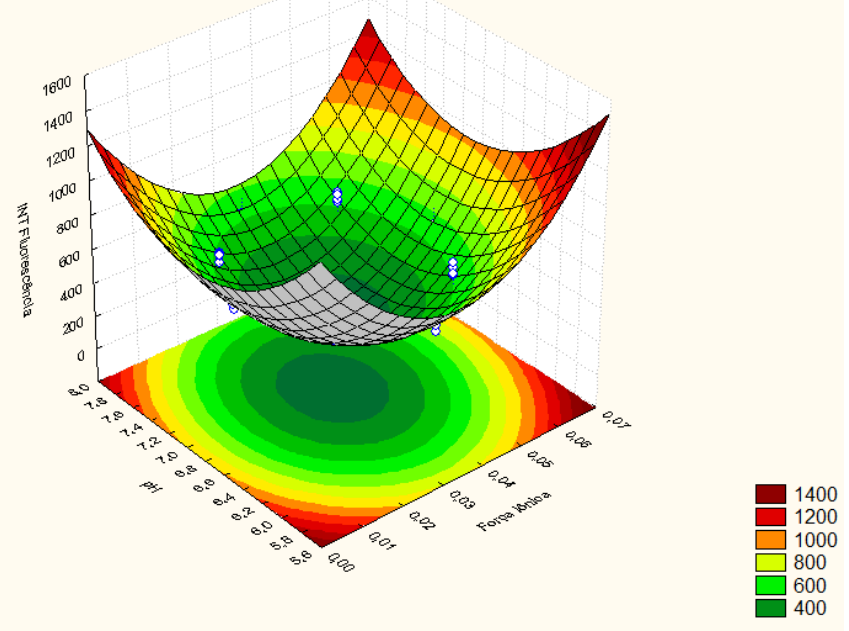

Figura 12: Representação gráfica do modelo de regressão gerado a partir do desenho experimental. Identifica-se o ponto crítico (ponto de mínimo) no valor de 236,85 . u.a.

\subsubsection{2.}

Cinética

O planejamento feito para a resposta da cinética da enzima AchEna fração protéica (do cérebro dos ratos) identificou efeitos principais significativos, nos níveis estudados, para as três variáveis: $\mathrm{pH}$, força iônica do tampão e tempo de incubação (Figura 12). Nesta faixa ótima de atividade da AChE, confirmou-se a importância das três variáveis e sua relação linear com a cinética da enzima. Nenhuma interação entre os fatores foi relevante para o modelo proposto.O sinal negativo dos efeitos indica que a relação entre as variáveis e a resposta (atividade aparente da $\mathrm{AChE} / \mathrm{min}$ ) é inversa. Isso quer dizer que, dentro do intervalo testado e considerando o peso de cada efeito, um aumento do tempo de incubação, do $\mathrm{pH}$ e/ou da força iônica do tampão resulta em menor atividade da AChE. 


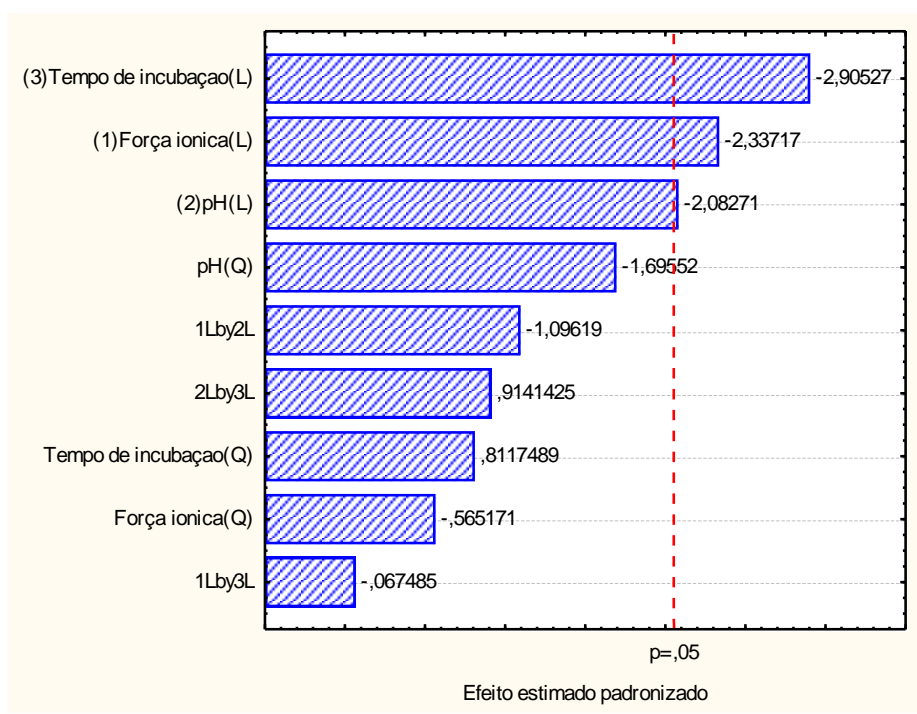

Figura 13 - Gráfico de Pareto indicando as 3 variáveis significativas e seus efeitos principais.

Pela tabela da estatística ANOVA (Tabela 7),observa-se que não foi possível obter um modelo matemático que descrevesse, suficientemente, o comportamento da cinética da $\mathrm{AChE}$ em função dos três parâmetros nos respectivos níveis considerados $\left(\mathrm{R}^{2}=0,49\right)$. Entretanto, não há falta de ajuste do modelo no domínio experimental de interesse (maior atividade enzimática).

Tabela 7 - Tabela ANOVA do modelo de regressão para a atividade aparente da AChE presente na fração protéica.

\begin{tabular}{cccc}
\hline $\begin{array}{c}\text { Fonte de } \\
\text { Variação }\end{array}$ & SQ & Gl & MQ \\
\hline Regressão & 0,0054 & 9 & 0,000599 \\
\hline Resíduo & 0,005658 & 26 & 0,0002176 \\
\hline Falta de ajuste & 0,002132 & 5 & 0,000426 \\
\hline Erro puro & 0,003526 & 21 & 0,0001679 \\
\hline Total & 0,011048 & 35 & \\
\hline $\begin{array}{c}\text { \% variação } \\
\text { explicável }\end{array}$ & & & \\
\hline
\end{tabular}




\% de variação
explicada pela
regressão

Apesar do modelo ter pouco poder de explicacão do conjunto de dados de cinética, identifica-se um domínio com correlação adequada entre os valores observados e previsto pelo modelo acima de 0,12 de atividade aparente/min (Figura 13). Este domínio compreeende a faixa experimental de maior atividade enzimática (condição de interesse) e por isso considera-se o modelo eficiente/adequado para o propósito deste planejamento (Figura 14).

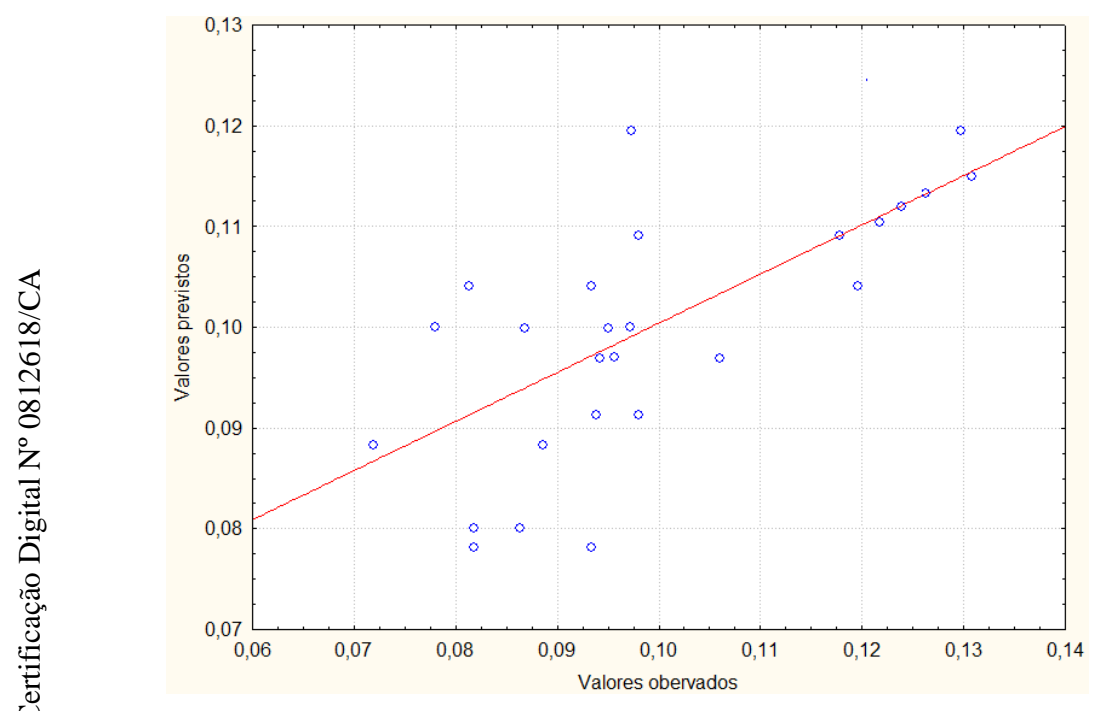

Figura 14 - Gráfico mostrando a correlação entre o modelo e os valores experimentais de fluorescência. 


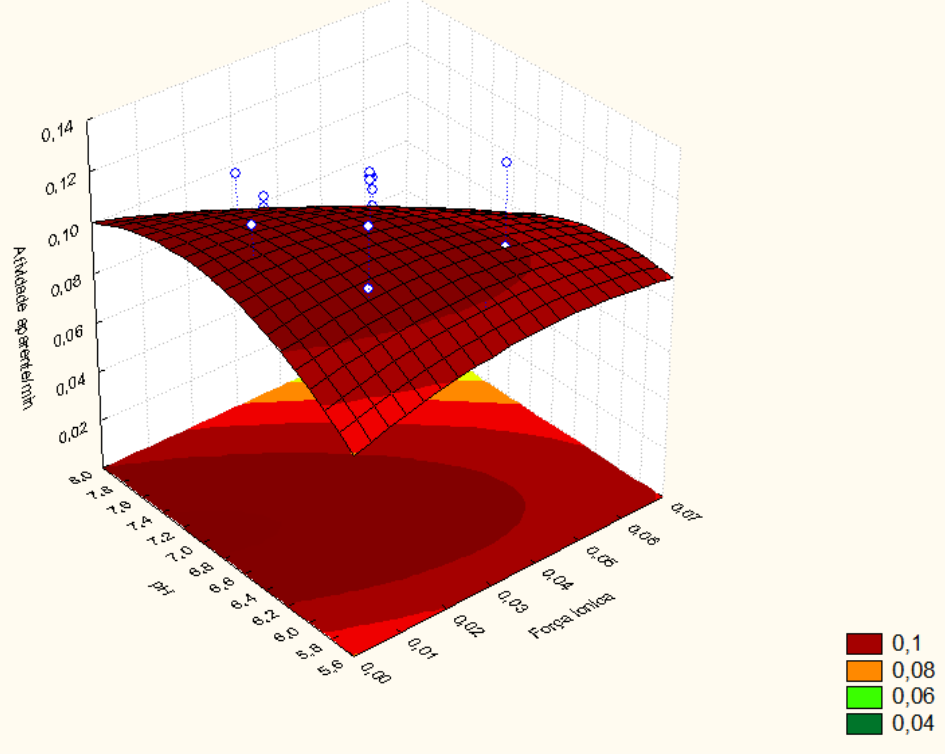

Figura 15 - Superfície de resposta com a cinética da AChE (expressa por atividade aparente/min). Ponto de sela: 0,108 de atividade aparente/min.

\subsection{2. \\ Fração protéica e resposta na presença dos analitos}

Através da análise dos efeitos e dos modelos de regressão tentou-se identificar alguma relação entre o comportamento de supressão de fluorescência da sonda e sua resposta específica sobre a atividade da AChE. Amedida da atividade catalítica da $\mathrm{AChE}$ e da fluorescência total das proteínas, sob as mesmas condições experimentais,ajuda a identificar as condições ótimas para as interações com os inibidores específicosda enzima e para a resposta de supressão de fluorescência com estes analitos.

Pela identificaçãode possíveis interseções nas superfícies de resposta, podese relacionar eventos de supressão de fluorescência com eventos de inibição catalítica da AChE. Dessa forma, pode-se discriminar a contribuição da interação com a enzima na resposta de supressão de fluorescência, jáqueos analitospodem interagir com mais de um componente da fração protéica (AChE e neuroreceptores, por exemplo).

No caso do biocomponente na ausência dos analitos (controle), o comportamento da emissão da fluorescência total das proteínas é influenciada pelos mesmo fatores que afetam a cinética da $\mathrm{AChE}$ (controle). Para um aumento da 
fluorescência deve-se diminuir opH, a força iônica e tempo de incubação. Já para se obter uma alta atividade catalítica, o efeito é na direção inversa (aumento dos valores das variáveis). Para os dois casos não existe influência das interações entre as variáveis nos valores das respostas.

Em relação à fração protéica (controle),o modelo gerado para a resposta de fluorescência explicou quase $80 \%$ da regressão dos $87 \%$ explicáveis. Porém, não se obteve um modelo suficiente para explicar a variação experimental da atividade específica da AChE, apesar dos dados estarem bem ajustados ao modelo linear. No entato, podemos extrair algumas informações importantes: (1) o planejamento com os analitos irá considerar as mesmas variáveis independentes; (2) a superfície de resposta da atividade enzimática confirma uma ampla faixa ótima de resposta; (3) uma sobreposição visual das suas superfícies mostra que a faixa com alta atividade catalítica apresenta, em sua maior parte, uma menor fluorescência da fração multiprotéica (ponto de mínimo).

Em seguida, os modelos de cinética e fluorescência do biocomponente na presença do analito serão comparados e sobrepostos aos respectivos controles.

\subsubsection{1.}

\section{Galantamina (GAL)}

\subsubsection{1.}

\section{Fluorescência}

\section{Estudo quimiométrico dos efeitos}

Na presença de $10 \mu \mathrm{gL}^{-1}$ de GAL, identificou-se efeitos relevantes dopH, da força iônica do tampão e do tempo de incubação em suas relações lineares e quadráticas com a resposta de fluorescência (Figura 15). A interação entre a força iônica do tampão e seu pH também foi significativa (linear). O tempo teve o menor efeito significativo positivo mostrando que um aumento do tempo de incubação com a GAL causa a diminuição na intensidade de fluorescência. Apenas as interações envolvendo o tempo não tiveram significância estatística. 


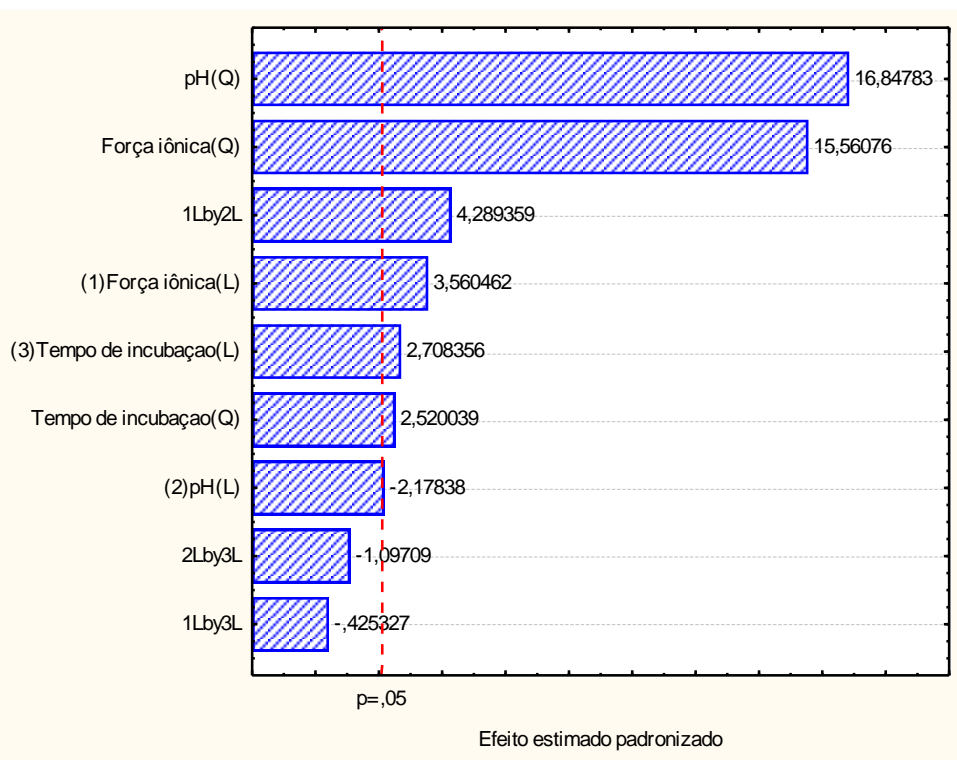

Figura 16 - Gráfico de Pareto identificando os fatores principais e as interações e suas significâncias estatísticas.

\section{$\underline{\text { Avaliacão do modelo (ajuste) }}$}

A regressão apresentou valor de $\mathrm{R}^{2}=74,09 \%$ de um total de $96,81 \%$ de variação explicável (Tabela 8). Apesar da falta de ajuste $\left(F_{f a j}=21,4\right)$,o gráfico de valores observados em função dos valores previstos mostra uma melhor correlação nas respostas menores de 500 u.a (Figura 16). O modelo (Figura 17) é útil para indicar as condições de mínimo com uma correlação suficiente. Neste modelo podemos considerar algumas sub-regiões/domínios que apresentam correlação entre os valores observados e previstos pelo modelo. 
Tabela 8 - Tabela ANOVA com os parâmetros de regressão.

\begin{tabular}{|c|c|c|c|}
\hline $\begin{array}{c}\text { Fonte de } \\
\text { Variação }\end{array}$ & SQ & Gl & MQ \\
\hline Regressão & 315735,1 & & 52622,52 \\
\hline Resíduo & 127039,2 & & 4380,662 \\
\hline Falta de ajuste & 100590,9 & & 14370,1 \\
\hline Erro puro & 14097,3 & 21 & 671,3 \\
\hline Total & 442774,3 & 35 & \\
\hline $\begin{array}{l}\text { \% variação } \\
\text { explicável }\end{array}$ & $96,81 \%$ & & \\
\hline $\begin{array}{l}\% \text { de variação } \\
\text { explicada pela } \\
\text { regressão }\end{array}$ & $74,09 \%$ & & \\
\hline
\end{tabular}

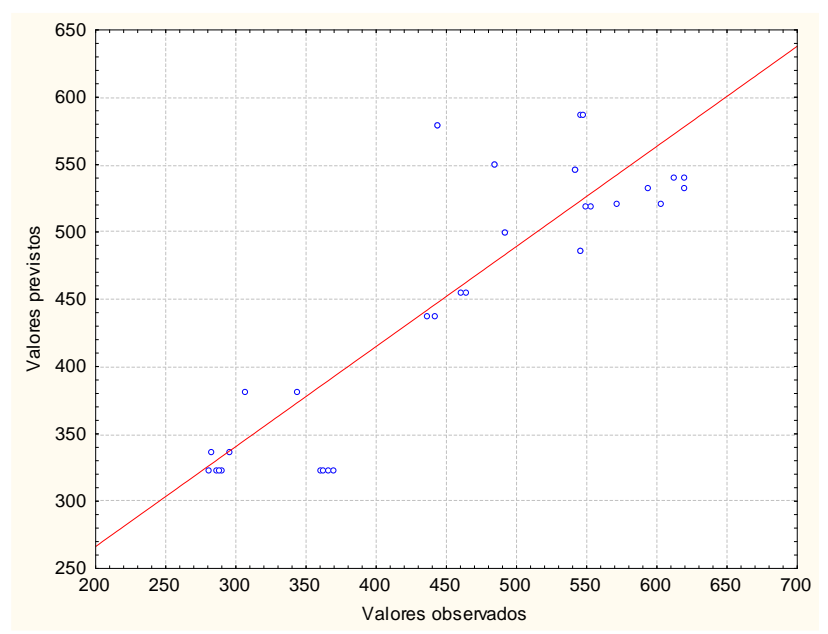

Figura 17 - Gráfico mostrando a correlação entre o esperado pelo modelo e os valores experimentais. 


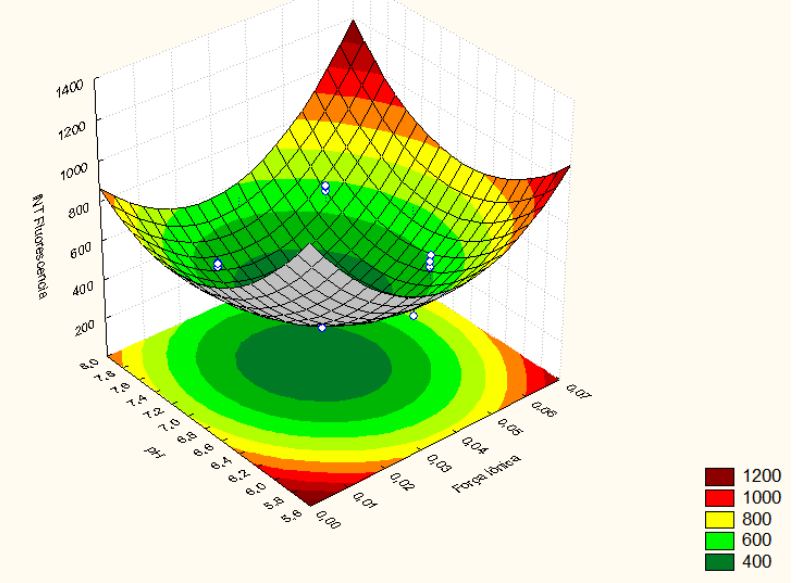

Figura 18 - Apresentação gráfica do modelo de regressão (superfície de reposta). Ponto de mínimo: 316,59.

\subsubsection{2. \\ Cinética}

Nesta faixa de trabalho, as variações das respostas de inibição na presença de GAL não foram significativas. Por isso, não se obteve um modelo de regressão satisfatório. Nesta faixa ótima de atividade (do controle) a inibição da AChEna presença de $62,25{\mu \mathrm{gL}^{-1}}$ de GAL ficou entre 9 e $53 \%$, com nenhum efeito relevantedas variáveis relacionadas (ver Figura 17). O gráfico dos efeitos para a atividade catalítca da $\mathrm{AChE}$ após a incubação com $62,25 \mu \mathrm{gL}^{-1}$ de galantamina mostra que na sua faixa ótima de atividade (do controle) a resposta de inibição do sistema pela Gal é robusta (Figura 18). 


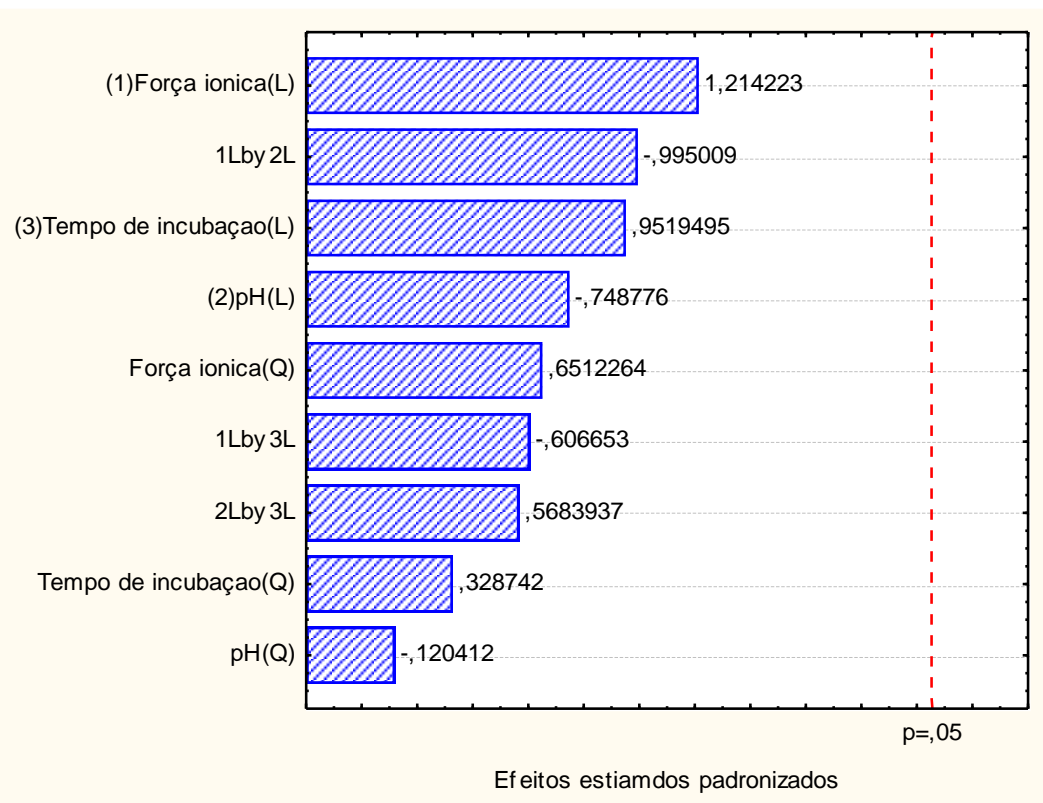

Figura 19 - Gráfico de Pareto indicando a ausência de influência dos três parâmetros na atividade enzimática da AChE.

\subsubsection{2. \\ Atropina}

\subsubsection{1.}

Fluorescência

\section{$\underline{\text { Estudo quimiométrico dos efeitos }}$}

No experimento com atropina, observa-seque os fatores relacionados ao tampão fosfato de sódio ( $\mathrm{pH}$ e força iônica) apresentam umarelação quadrática com a intensidade de fluorescência total das proteínas. Além de provocarem essa influência direta, sua interação também apresenta significância estatística (ao nível de $95 \%$ de confiança). Para este analito, o tempo de incubação, nas condições escolhidas, não foi relevante (Figura 19). 


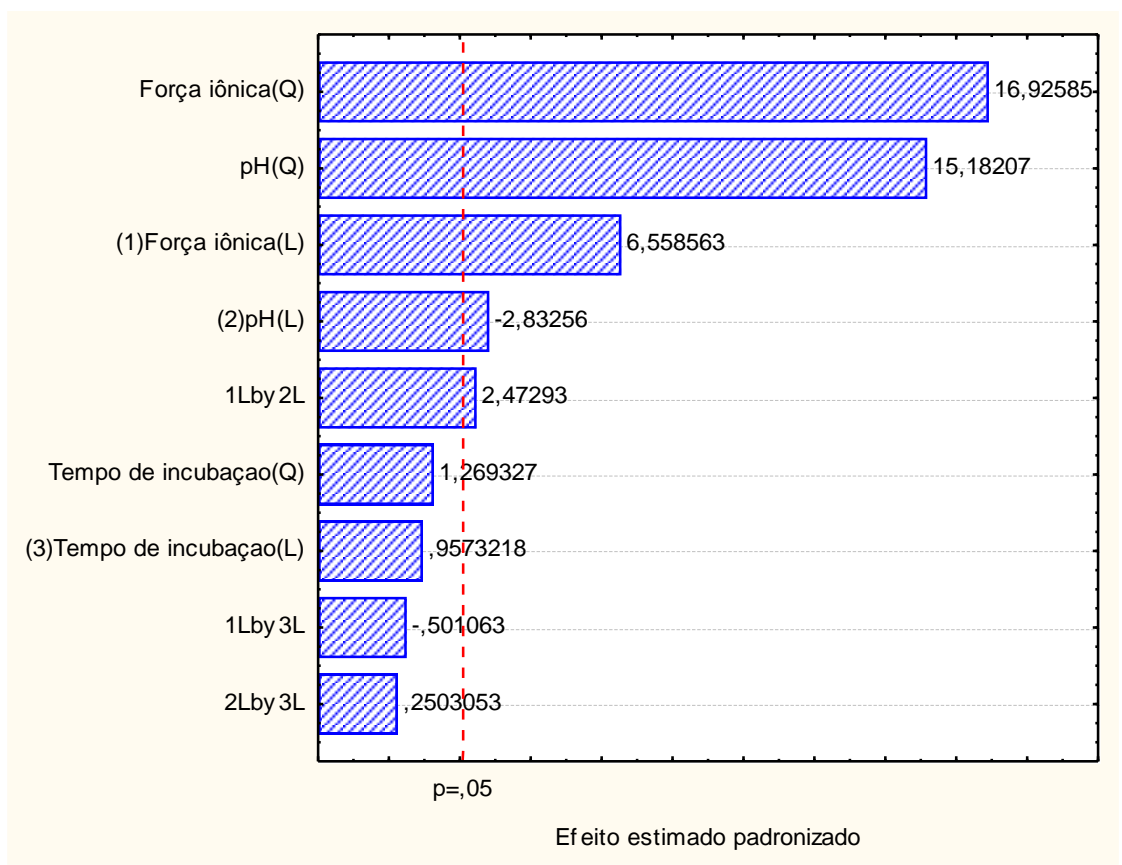

Figura 20 - Gráfico de Pareto identificando os fatores e suas interações no sistema incubado com atropina $\left(10 \mu \mathrm{gL}^{-1}\right)$.

\section{$\underline{\text { Avaliacão do modelo }}$}

Pode-se verificar numericamente a qualidade do ajuste através da Análise de Variância (ANOVA) mostrada na Tabela 9. A variação percentual explicada pelo modelo proposto $\left(\mathrm{R}^{2}\right)$ é igual a $90,31 \%$ e a percentagem máxima de variação explicável fica em 96,25\%.O modelo (Figura 21) apresenta uma pequena falta de ajuste $\left(\mathrm{F}_{\text {faj }}=6,6\right)$ que não foi considerada importante para o propósito deste planejamento. A correlação entre os valores esperados e os observados (Figura 19) se mostrou apropriada para a faixa de interesse do sinal de fluorescência (próximo ao ponto de mínimo). 
Tabela 9 - Tabela ANOVA do modelo de regressão.

\begin{tabular}{|c|c|c|c|}
\hline $\begin{array}{c}\text { Fonte de } \\
\text { Variação }\end{array}$ & SQ & gl & MQ \\
\hline Regressão & 402918,2 & 9 & 44768,69 \\
\hline Resíduo & 44023,79 & 26 & 1595,65 \\
\hline Falta de ajuste & 25448,1 & 5 & 5089,6 \\
\hline Erro puro & 16039,0 & 21 & 763,8 \\
\hline Total & 428222,9 & 35 & \\
\hline $\begin{array}{l}\text { \% variação } \\
\text { explicável }\end{array}$ & 90,31 & & \\
\hline $\begin{array}{l}\text { \% de variação } \\
\text { explicada pela } \\
\text { regressão }\end{array}$ & 96,25 & & \\
\hline
\end{tabular}

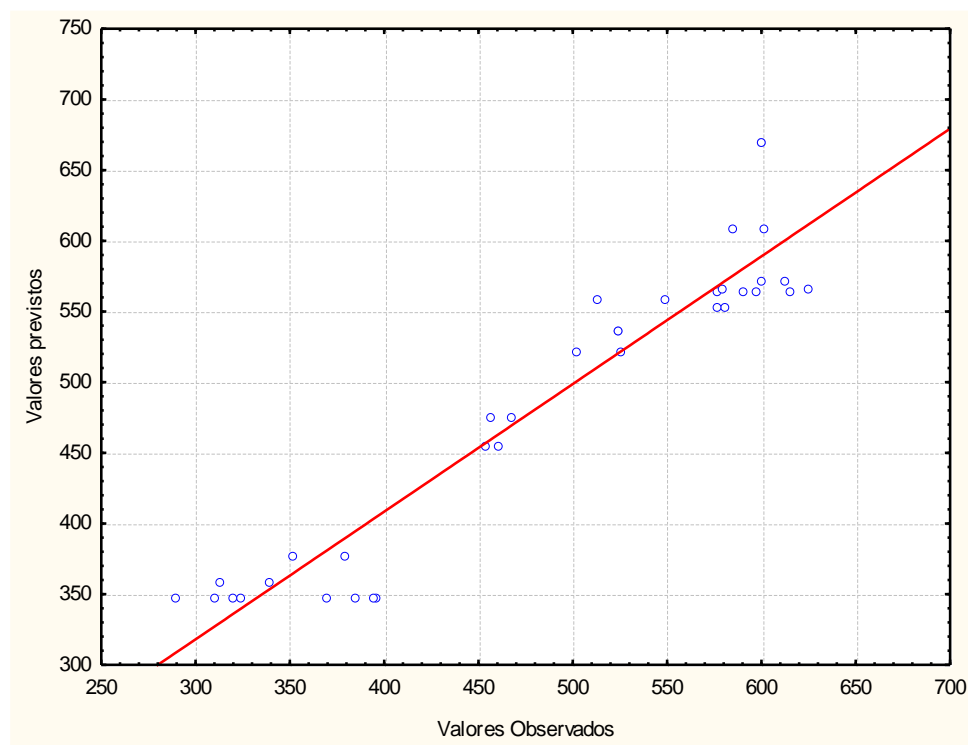

Figura 21 - Gráfico mostrando a correlação entre os valores previstos e observados. Para os menores valores de intensidade de sinal (próximo à 300 350 u.a). 


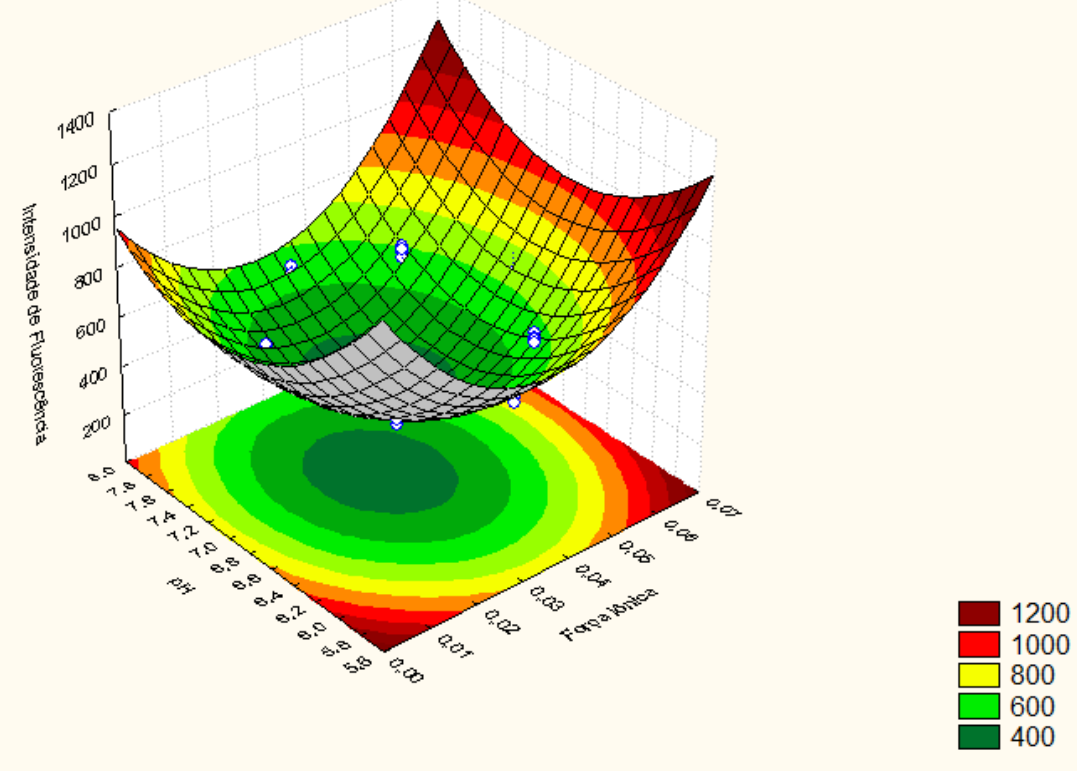

Figura 22 - Superfície de resposta do modelo de regressão obtido para o sinal de fluorescência da fração protéica na presença de $10 \mu \mathrm{gL}^{-1}$ de atropina. Ponto de mínimo em 341,66 u.a.

\subsubsection{2.}

\section{Cinética}

$\mathrm{Na}$ incubação com atropina, não houve efeito principal significativo, somente foi importante a interação linear entre a força iônica do tampão e o tempo de incubação do ensaio. Esta interação, de coeficiente negativo, mostra que o aumento do valor de ambas variáveis resulta em diminuição da resposta cinética da enzima após sua incubação com atropina (Figura 22). Portanto, a inibição da AChE pela atropina, nestas condições experimentais, depende não do valor do $\mathrm{pH}$ do meio, mas sim do tempo de contato entre a enzima e o analito em condições específicas do tampão. 


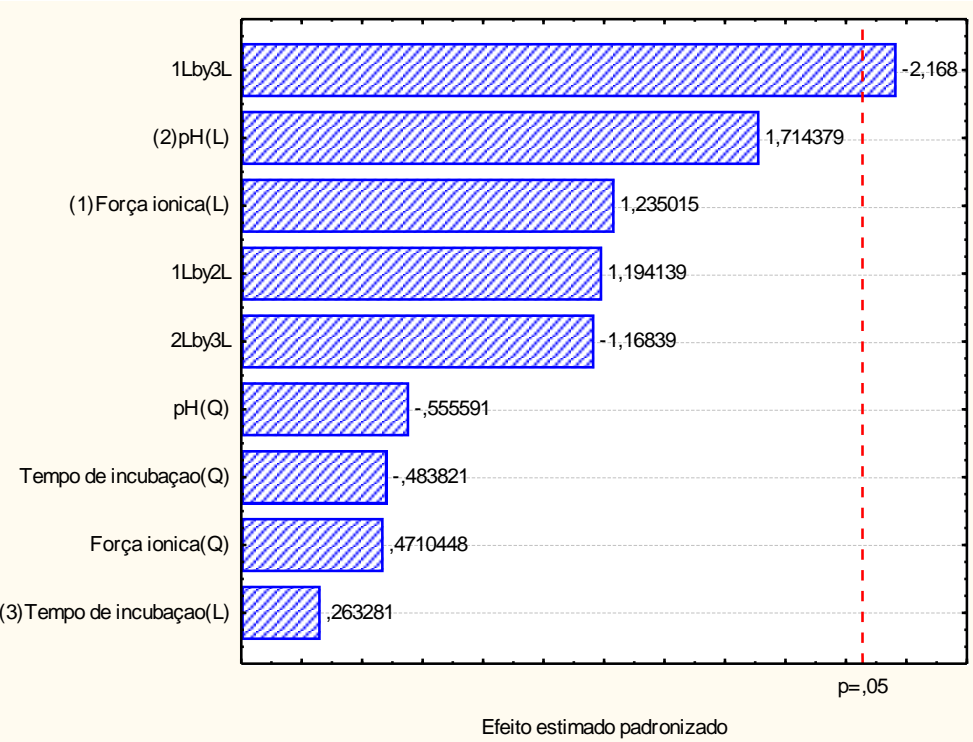

Figura 23 - Gráfico de Pareto para a atividade específica da AChE presente na fração protéica na presença de $62,25 \mu \mathrm{gL}^{-1}$ de atropina.

A inibição da atividade com $62,25 \mu \mathrm{gL}^{-1}$ de atropina foi de 0 à $68 \% . \mathrm{O}$ modelo de regressão gerado é muito precário $\left(\mathrm{R}^{2}=0,33\right)$, com uma capacidade insatisfatória de explicação dos dados experimentaisnesta faixa de trabalho.Os ensaios de atividade enzimática nestas condições são muito robustos, sendo a resposta bem insensível aos fatores relacionados. Apesar disso não houve falta de ajuste do modelo linear (Figura 23).

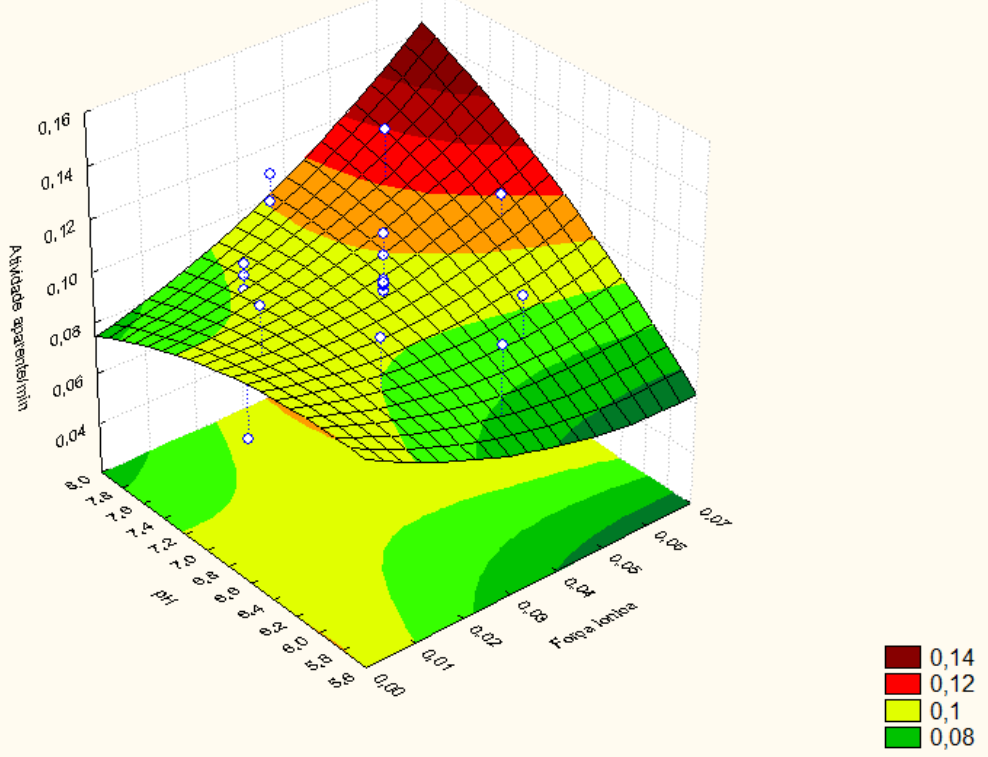

Figura 24 - Gráfico de superfície de resposta para a atividade aparente da AChE após incubação com $62,25 \mu g \mathrm{~L}^{-1}$ de atropina. 


\subsubsection{3.}

Metomil

\subsubsection{1.}

Fluorescência

\section{Estudo quimiométrico dos efeitos}

No gráfico de Pareto (Figura 24) são mostradas as significâncias estatísticas das variáveis força iônica e pH do tampão (termo quadrático) e do termo linear do pHpara a intensidade do sinal de fluorescência da fração após incubação com o carbamato metomil na concentração de $5 \mu \mathrm{gL}-1$. O efeito negativo deste fator indica que os maiores valores de resposta (intensidade de fluorescência) se encontram na direção dos menores valores de pH do tampão. Em outras palavras, as menores intensidades de fluorescência da fração protéica são observadas a medida que se aumenta o pH do meio. O tempo de incubação, mais uma vez, não apresenta importância no desenho experimental proposto assim como não há interações entre os fatores de nenhuma ordem. 


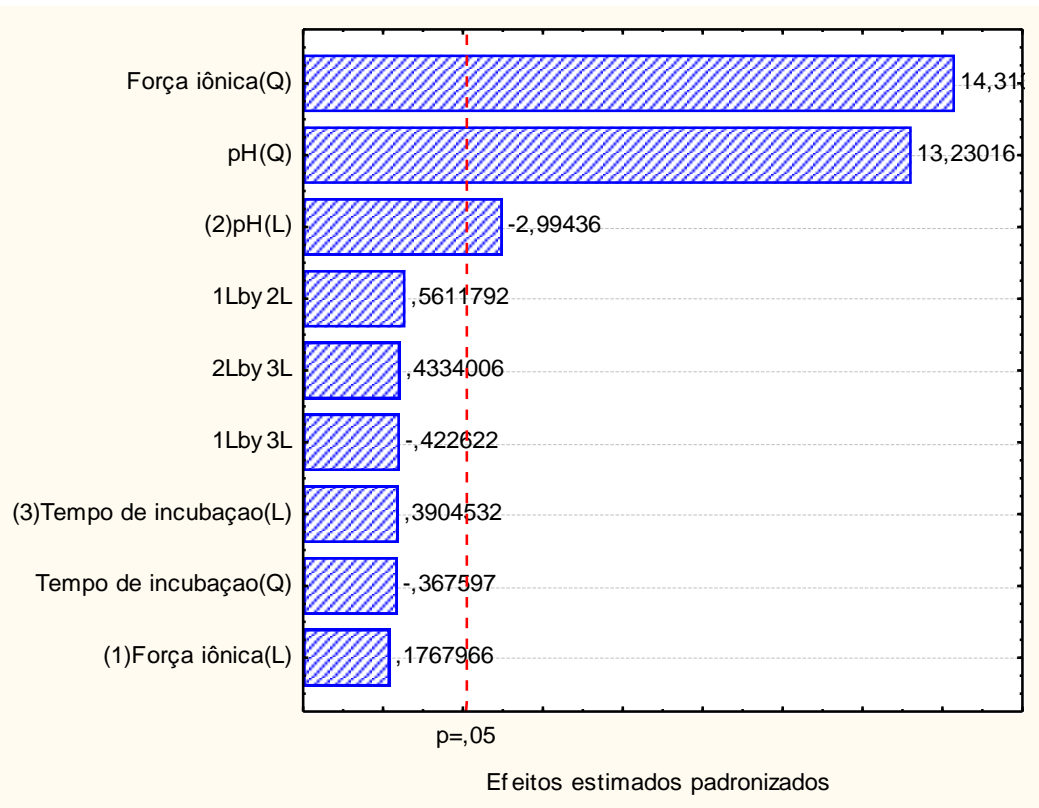

Figura 25 - Gráfico de Pareto mostrando os valores dos efeitos para a intensidade do sinal de fluorescência da fração protéica.

\section{Avaliação do modelo}

A estatística ANOVA (Tabela 10) mostra que o modelo proposto explica 90\% da variação da resposta de fluorescência de um total de $95 \%$ de capacidade explicativa da regressão. A falta de ajuste $\left(\mathrm{F}_{\text {faj }}=3,82\right)$ não é suficiente para descartar o modelo proposto. O gráfico de resíduos (Figura 25) mostra a dipersão aleatória dos resíduos indicando um ajuste do modelo de regressão suficiente para descrever o comportamento do sinal de fluorescência total (fração protéica) após a incubação com $5 \mu \mathrm{gL}^{-1}$ de metomil. Portanto, o modelo éajustado suficientemente e tem boa capacidade de explicar as respostas na presença de metomil $\left(5 \mu \mathrm{gL}^{-1}\right)$ como visto na Figura 25. 
Tabela 10 - Tabela ANOVA do modelo de regressão quadrática para a resposta de intensidade de fluorescência da fração protéica.

\begin{tabular}{|c|c|c|c|}
\hline $\begin{array}{c}\text { Fonte de } \\
\text { Variação }\end{array}$ & SQ & GI & MQ \\
\hline Regressão & 361317.6 & 9 & \\
\hline Resíduo & 41087.44 & 26 & 1580.3 \\
\hline Falta de ajuste & 1957.2 & 5 & 3914.4 \\
\hline Erro puro & 21515.4 & 21 & 1024.5 \\
\hline Total & 402405.0 & 35 & \\
\hline $\begin{array}{l}\text { \% variação } \\
\text { explicável }\end{array}$ & $90 \%$ & & \\
\hline $\begin{array}{l}\text { \% de variação } \\
\text { explicada pela } \\
\text { regressão }\end{array}$ & $95 \%$ & & \\
\hline
\end{tabular}

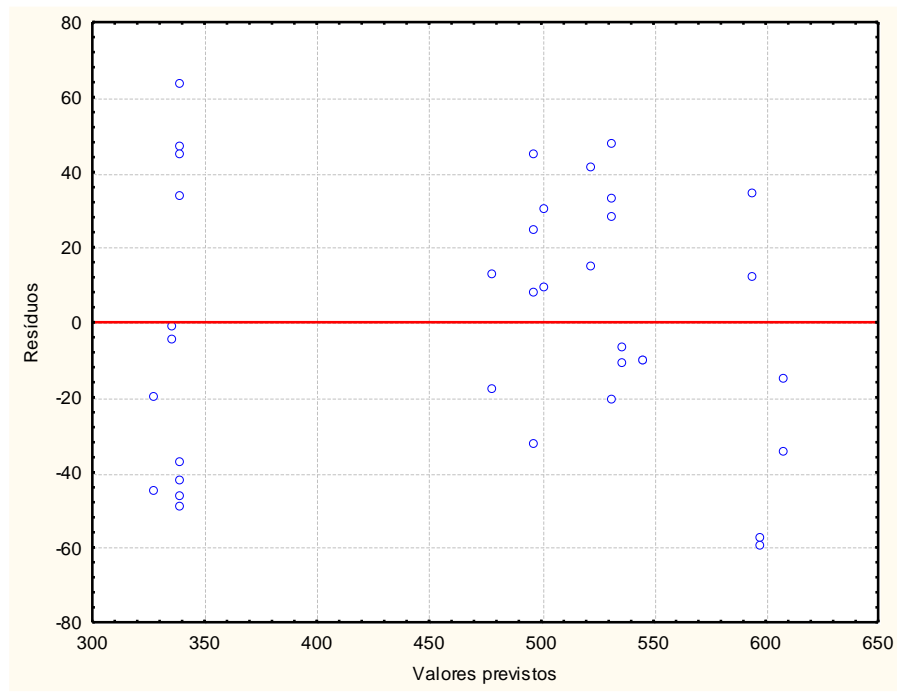

Figura 26 - Gráfico de resíduos (comportamento do sinal de fluorescência total da fração protéica) após a incubação com $5 \mu \mathrm{gL}^{-1}$ de metomil. 


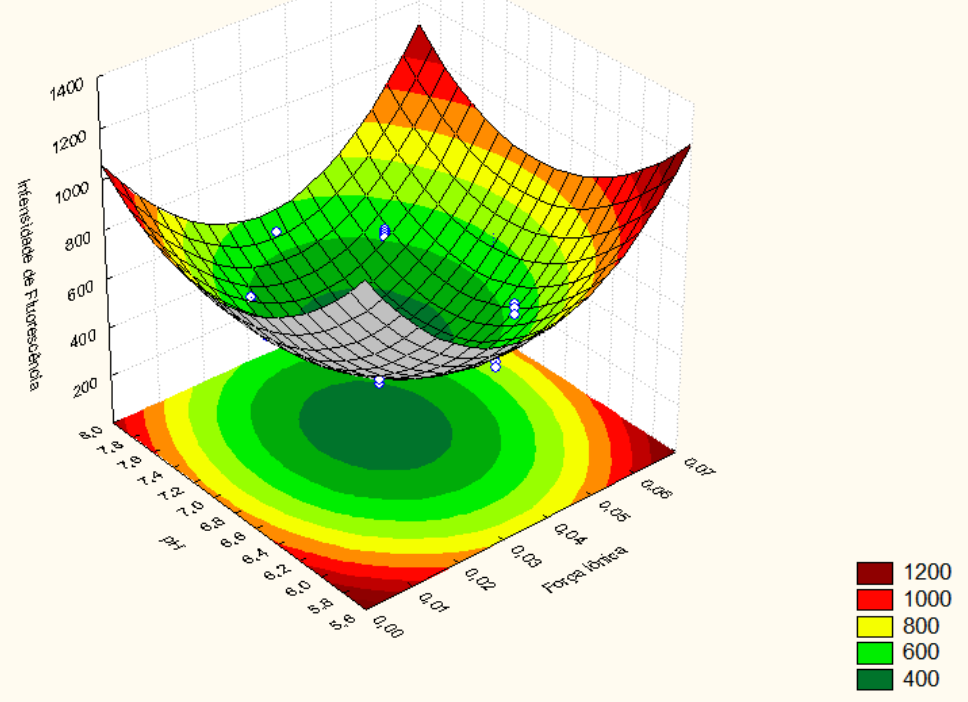

Figura 27 - Superfície de resposta do modelo após incubação com $5 \mu \mathrm{gL}$ 1 de metomil. Ponto de sela de 338,77 u.a.

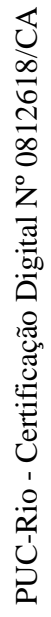

\subsubsection{2. \\ Cinética}

Para as incubações com $31,12 \mu \mathrm{gL}^{-1}$ de metomil, a atividade enzimática da AChE mostrou ser influenciada somente pelo $\mathrm{pH}$ do meio,como mostrado no gráfico de Pareto (Figura 27).

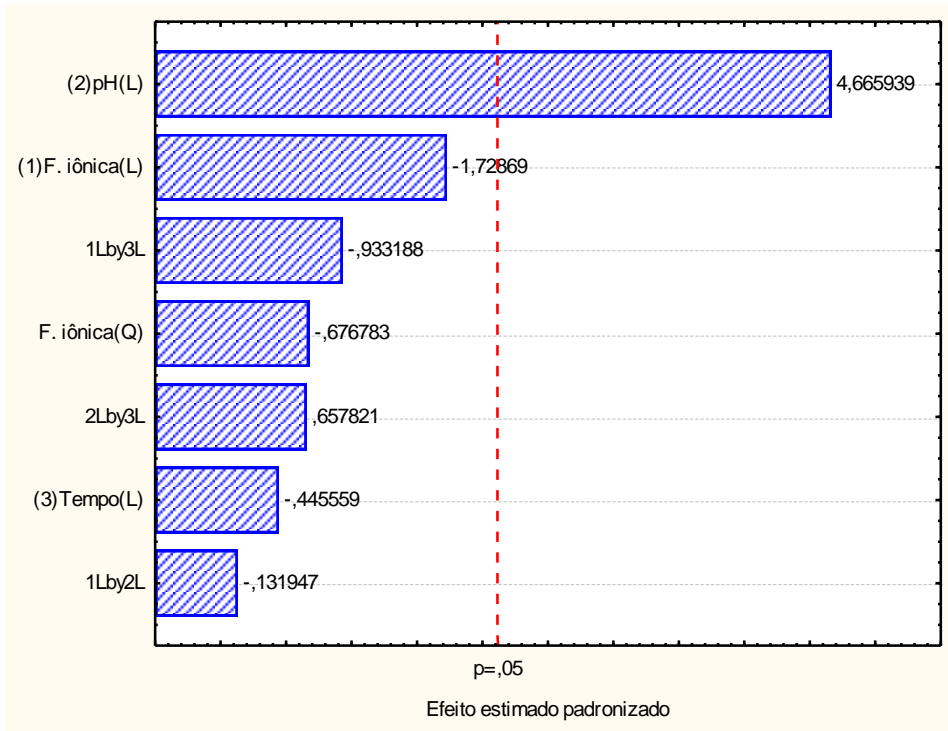

Figura 28 - Gráfico dos valores dos coeficientes dos efeitos sobre a atividade aparente da $\mathrm{AChE}$. 


\section{Avaliação do modelo}

Pelo planejamento, o modelo de regressão mais adequado é o linear $\left(\mathrm{R}^{2}=\right.$ $62,5)$ com uma capacidade explicativa total do conjunto dos dados experimentais de 65,6\% (Tabela 11). O conjunto de dados observados apresentam valores de inibição da atividade pelo analito entre 57 e 89\%. O gráfico dos resíduos (Figura 28) mostra a adequação do modelo linear (Figura 29) aos dados de cinética da AChE na presença de metomil. Na figura 29 está a representação gráfica do modelo de regressão linear (superfície de resposta) da atividade enzimática aparente da AChE em função do pH e força iônica no tempo de 30 minutos de incubação do sistema com $31,12 \mu \mathrm{gL}^{-1}$ de metomil

Tabela 11 - Tabela ANOVA do modelo de regressão linear.

\begin{tabular}{|c|c|c|c|}
\hline $\begin{array}{c}\text { Fonte de } \\
\text { Variaçãa }\end{array}$ & SQ & gl & MQ \\
\hline Regressão & 0.001142 & 7 & 0.000163 \\
\hline Resíduo & 0.000684 & 16 & 0.000041 \\
\hline Falta de ajuste & 0.000056 & 1 & 0.000056 \\
\hline Erro puro & 0.00064 & 16 & 0.00004 \\
\hline Total & 0.001859 & 25 & \\
\hline $\begin{array}{l}\text { \% variação } \\
\text { explicável }\end{array}$ & $62,5 \%$ & & \\
\hline $\begin{array}{l}\text { \% de variação } \\
\text { explicada pela } \\
\text { regressão }\end{array}$ & $65,6 \%$ & & \\
\hline
\end{tabular}




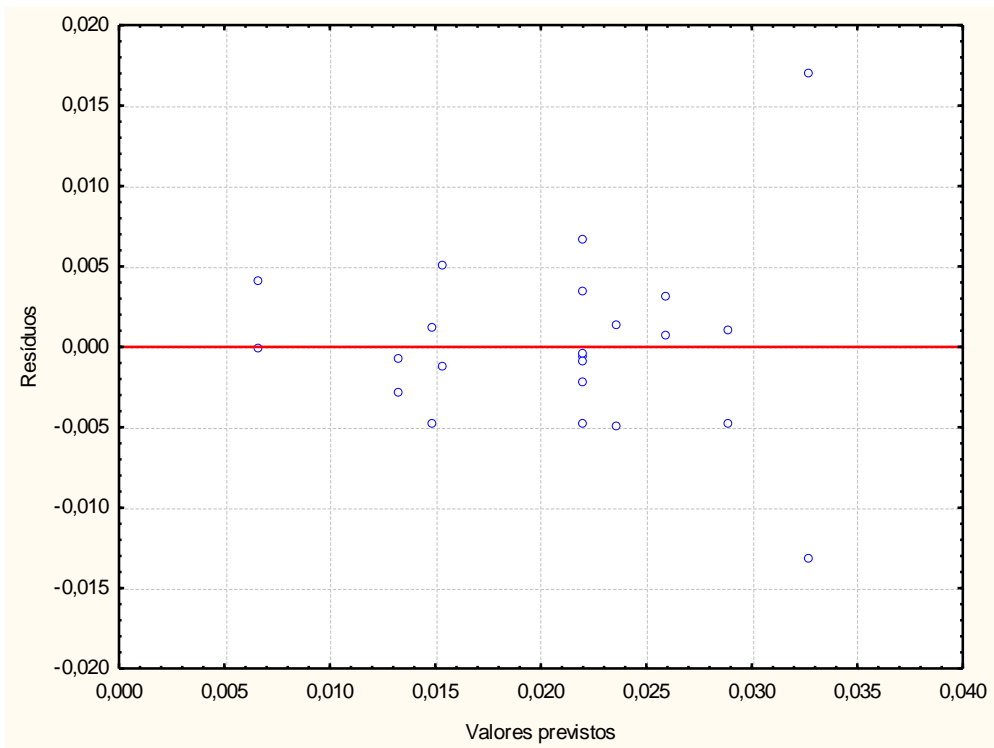

Figura 29 - Gráfico indicando o ajuste do modelo linear previsto cuja distribuição dos resíduos é aleatória.

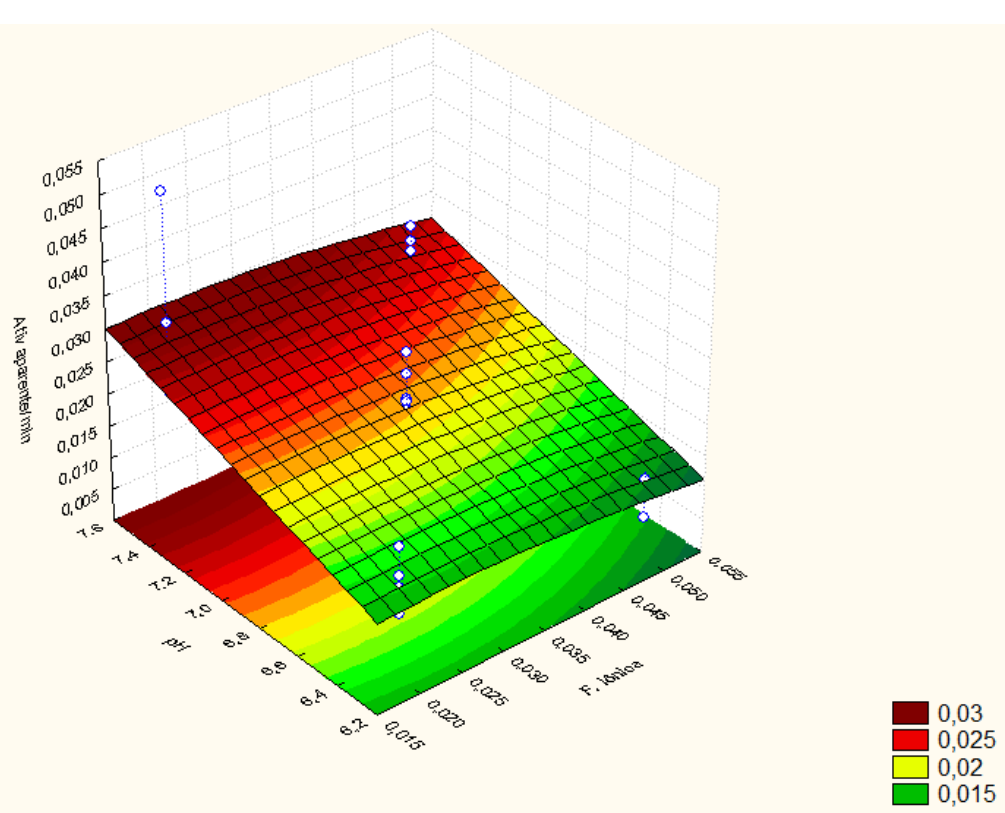

Figura 30 - Representação gráfica do modelo de regressão linear da atividade enzimática aparente da AChE tempo de 30 minutos de incubação do sistema. 


\subsubsection{4.}

\section{Metamidofós}

\subsubsection{1.}

Fluorescência

No gráfico dos efeitos (Figura 30) se observa a influência significativa das três variáveis estudadas sobre a fluorescência total da fração após incubação com $40 \mu \mathrm{g} \mathrm{L}^{-1}$ de metamidofós. Todos os efeitos principais foram relevantes para o sinal de fluorescência (relação linear e quadrática). $\mathrm{O}$ aumento do tempo de contato com o material biológico contribui significativamente para a diminuição do sinal. As interações não tiveram efeito significativo para a resposta de fluorescência.

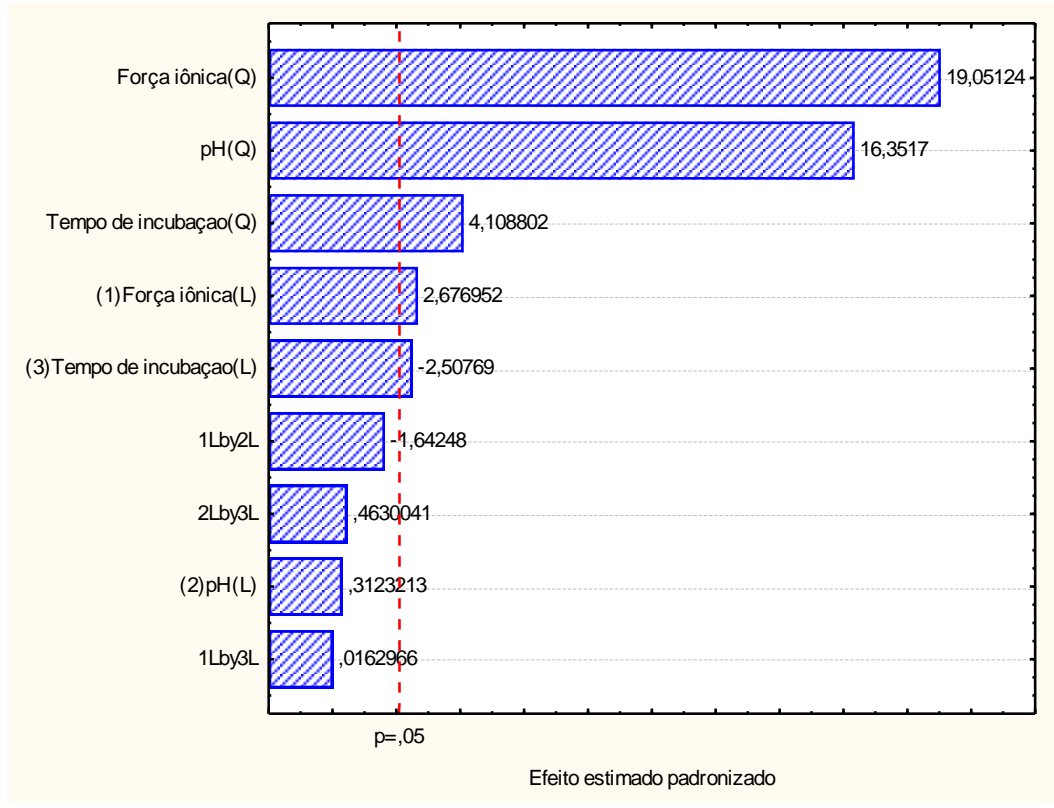

Figura 31 - Gráfico de Pareto indicando os coeficientes dos efeitos das variaveis e suas interações.

A análise de ANOVA (Tabela 12) do modelo gerado indica que grande parte da variação de fluorescência pode ser explicado por modelos de regressão. A maior fonte da variação vem do erro experimental e não da falta de ajuste do modelo $\left(F_{\text {faj }}\right.$ $=6,6)$. O modelo gerado $\left(\mathrm{R}^{2}=90,9 \%\right)$ foi considerado satisfatório para explicar o comportamento do sinal fluorescente na presença de metamidofós. Os dados do gráfico de resíduos (Figura 31) mostram que, apesar da indicação de pequena falta de ajuste pela ANOVA, o modelo é adequado (Figura 32). 
Tabela 12 - Tabela ANOVA do modelo de regressão linear sem falta de ajuste importante $\left(F_{\text {falta de ajuste }}=\mathbf{6 , 6}\right)$.

\begin{tabular}{clll}
\hline $\begin{array}{c}\text { Fonte de } \\
\text { Variação }\end{array}$ & SQ & GI & MQ \\
\hline Regressão & 496520,8 & 9 & 55168,9 \\
Resíduo & 49329,39 & 26 & \\
Falta de ajuste & 30149,8 & & \\
Erro puro & 19179,6 & 5 & \\
Total & 545850 & 35 & \\
\hline $\begin{array}{c}\text { \% variação } \\
\text { explicável }\end{array}$ & 96,5 & & \\
\% de variação & 90,9 & \\
explicada pela \\
regressão
\end{tabular}

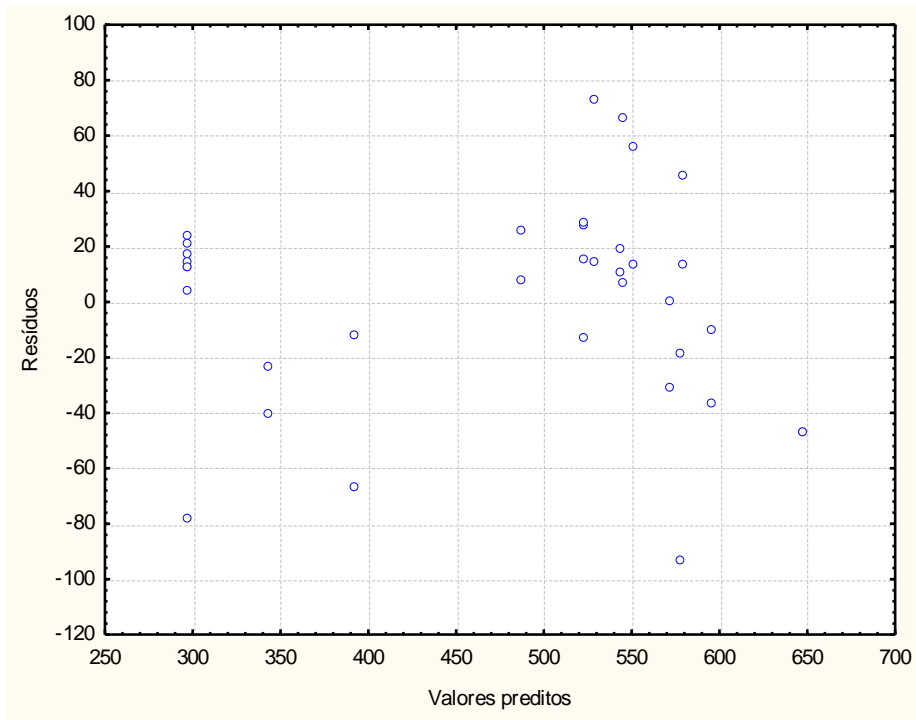

Figura 32 - Gráfico mostrando a distribuição aleatória dos resíduos, indicando a adequação do modelo proposto pelo planejamento. 


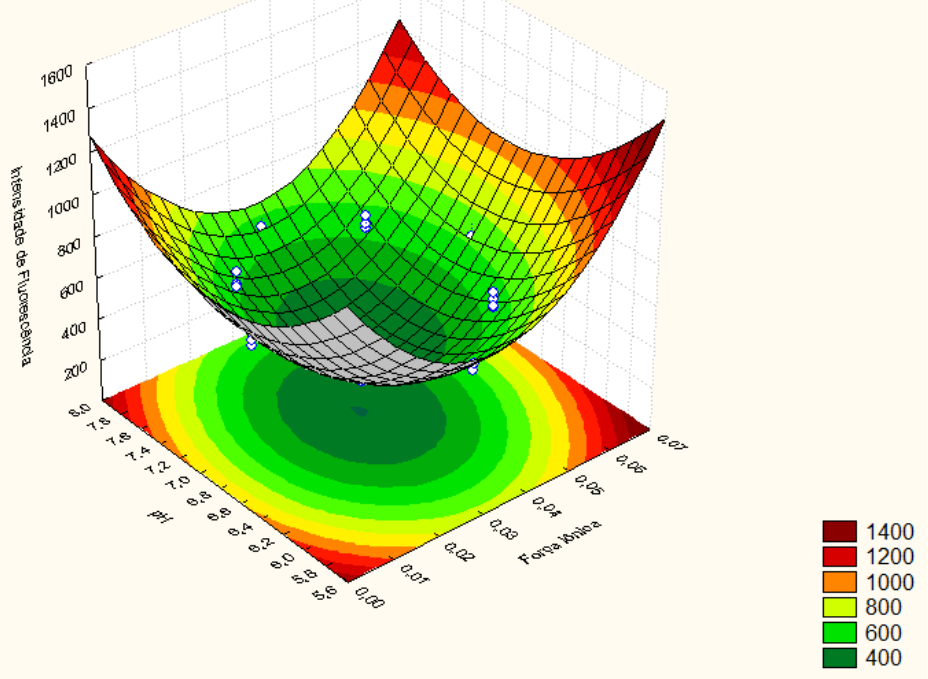

Figura 33 - Representação gráfica do modelo quadrático gerado para a resposta de fluorescência da fração protéica na presença de $40 \mu \mathrm{gL}^{-1}$ metamidofós . Ponto de mínimo: 295 u.a.

\subsubsection{2. \\ Cinética}

Os efeitos significativos para a resposta de atividade da AChE após a incubação com $31,12 \mu \mathrm{gL}^{-1}$ de metamidofós mostra a influência apenas dos termos lineares. Observa-se uma relação inversa entre a atividade da $\mathrm{AChE}$ com o tempo de incubação (maior efeito). O aumento do tempo de incubação implica em menor atividade enzimática, ou seja, maior inibição da AChE pelo contato com o pesticida (Figura 32). A inibição observada na atividade da AChE após incubação com metamidofós foi entre 82 e $46 \%$ aproximadamente expressa em termos de atividade aparente $\min ^{-1}$ (Figura 33). 


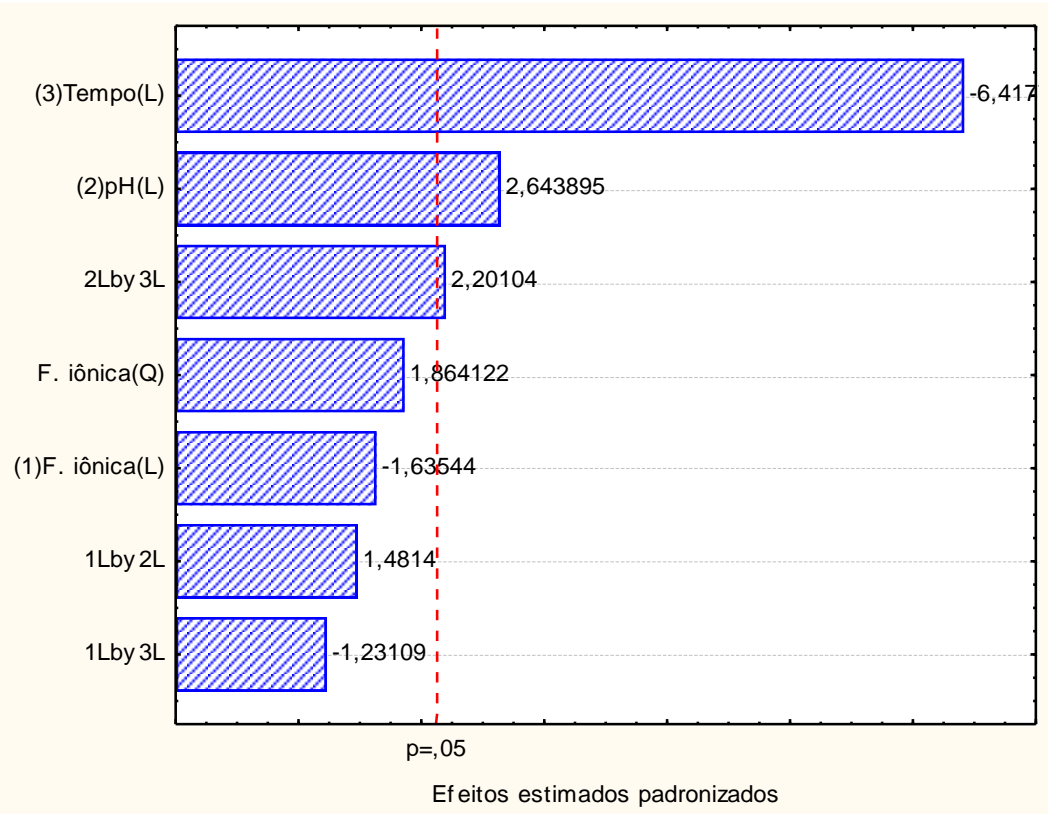

Figura 34 - Gráfico de Pareto mostrando os coeficientes do efeitos do modelo linear para a atividade da $\mathrm{AChE}$ napresença de metamidofós.

A análise de ANOVA (Tabela 13) indicou o modelo linear (Figura 34) bem ajustado aos dados de cinética da AChE com metamidofós com umaporcentagem explicada de $75 \%$ da variação (de um total de 80,3\%). Na figura 34 está a representaçãodo modelo linear que relaciona as variáveis independentes ( $\mathrm{pH}$ e força iônica do tampão) com a atividade enzimática da AChE após 100 minutos de incubação com $31,12 \mu \mathrm{gL}^{-1}$ de metamidofós.

Tabela 13 - Tabela ANOVA do modelo de regressão linear (sem falta de ajuste)

\begin{tabular}{clll}
\hline $\begin{array}{c}\text { Fonte de } \\
\text { Variação }\end{array}$ & SQ & gl & MQ \\
\hline Regressão & 0.001696 & 7 & 0.000242 \\
Resíduo & 0.000432 & 16 & 0.0000309 \\
Falta de ajuste & 0.000107 & 2 & 0.000053 \\
Erro puro & 0.000419 & 15 & 0.0000279 \\
Total & 0.002128 & 23 & \\
\hline
\end{tabular}




\begin{tabular}{cc}
\hline $\begin{array}{c}\text { \% variação } \\
\text { explicável }\end{array}$ & $80.31 \%$ \\
$\begin{array}{c}\text { \% de variação } \\
\text { explicada pela } \\
\text { regressão }\end{array}$ & $75 \%$ \\
\hline
\end{tabular}

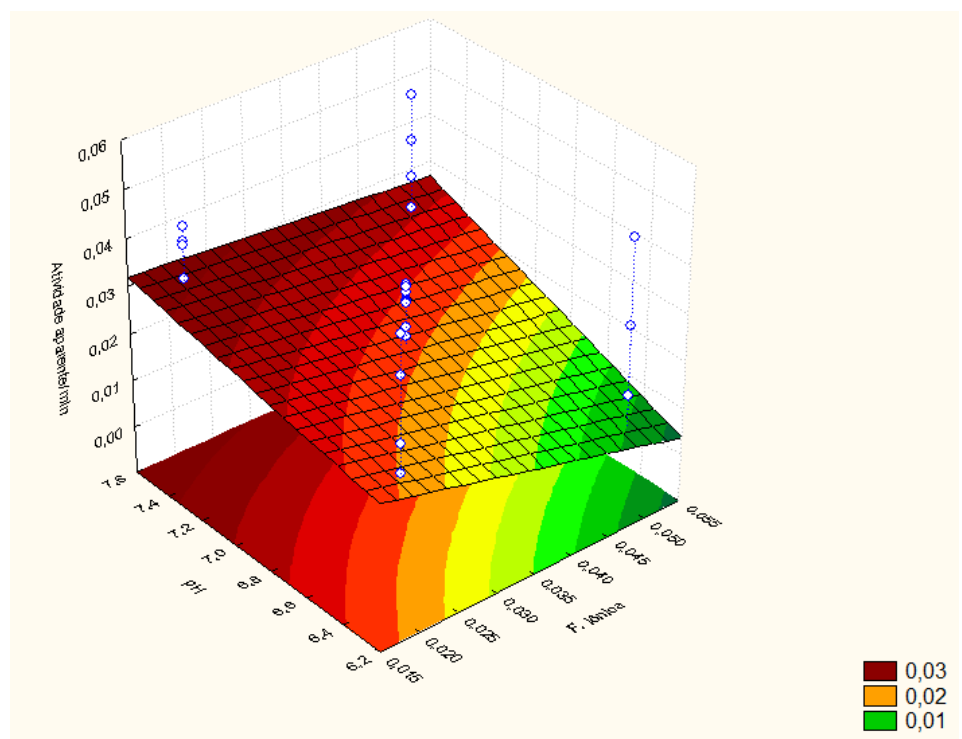

Figura 35 - Representaçãodo modelo linear que relaciona as variáveis independentes com a atividade enzimática da AChE após 100 minutos de incubação.

\subsubsection{5.}

Metil paration

\subsubsection{1.}

\section{Fluorescência}

O estudo do efeito do metil paration sobre a fluorescência da fração protéica não foi realizado, pois seu comportamento seria similar ao do metamidofós (o outro organofosforado) visto que o sítio de interação localizado na molécula de AChE é o mesmo assim como seu mecanismo de interação. 


\subsubsection{2. \\ Cinética}

\section{$\underline{\text { Estudo quimiométrico dos efeitos }}$}

Apesar da ausência de testes da fração protéica para atividade de outras enzimas, principalmente as relacionadas à ativação de sua forma tóxica (paraoxon), houve significativa inibição (40 e 70\%) da atividade da enzima AChE por $20 \mu \mathrm{g} \mathrm{L}$ ${ }^{1}$ de metil paration. As variáveis significativas foram o valor de $\mathrm{pH}$ do meio e o tempo de incubação e suas interações ( $\mathrm{pH}$ versus tempo) que variaram linearmente com a resposta da atividade enzimática. O sinal negativo do coeficientedo efeito do tempo indica que a inibição enzimática aumenta com o tempo de incubação sugerindo que este parâmetro seja fundamental para a conversão da molécula do organofosforado em sua forma inibidora da enzima (paraoxon) (Figura 35).

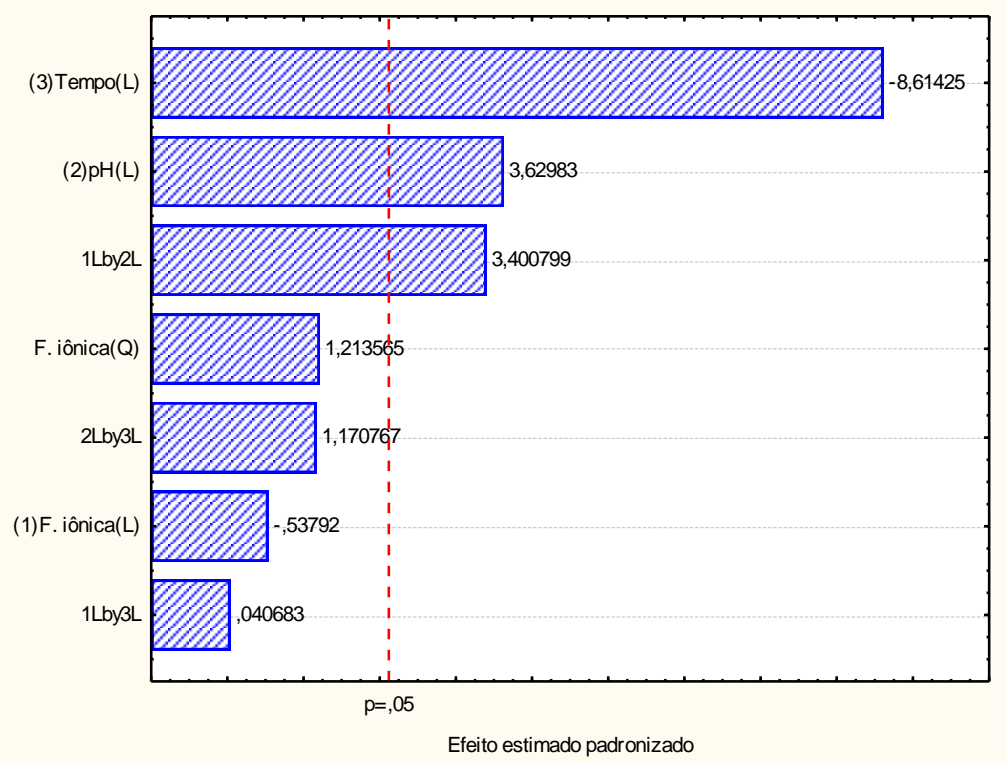

Figura 36 - Gráfico de pareto indicando a influência das variáveis sobre a atividade aparente da $\mathrm{AChE}$ após incubação com $20 \mu \mathrm{g} \mathrm{L}^{-1}$ de metil paration. 
Na Tabela 14 é mostrado um coeficiente de correlação múltipla de $85 \%$ de um total de $88,9 \%$ de variação explicada por regressão. O modelo linear proposto (Figura 36) mostra estar bem ajustado aos dados experimentais (Figura 37) e se mostra adequado para o estudo do comportamento da cinética da $\mathrm{AChE}$ (da fração protéica) frente ao inibidor metil paration.

Tabela 14 - Tabela ANOVA do modelo de regressão linear (sem falta de ajuste)

\begin{tabular}{clll}
\hline $\begin{array}{c}\text { Fonte de } \\
\text { Variação }\end{array}$ & SQ & gl & MQ \\
\hline Regressão & 0.001756 & 7 & 0.000275 \\
Resíduo & 0.000275 & 16 & 0.0000177 \\
Falta de ajuste & 0.000076 & 2 & 0.000038 \\
Erro puro & 0.000225 & 15 & 0.000015 \\
Total & 0.002032 & 23 & \\
\hline $\begin{array}{c}\text { \% máxima de } \\
\text { variação explicável }\end{array}$ & $88,93 \%$ & & \\
\% máxima de & $85 \%$ & & \\
\hline $\begin{array}{c}\text { variação explicada } \\
\text { pela regressão }\end{array}$ & & & \\
\hline
\end{tabular}




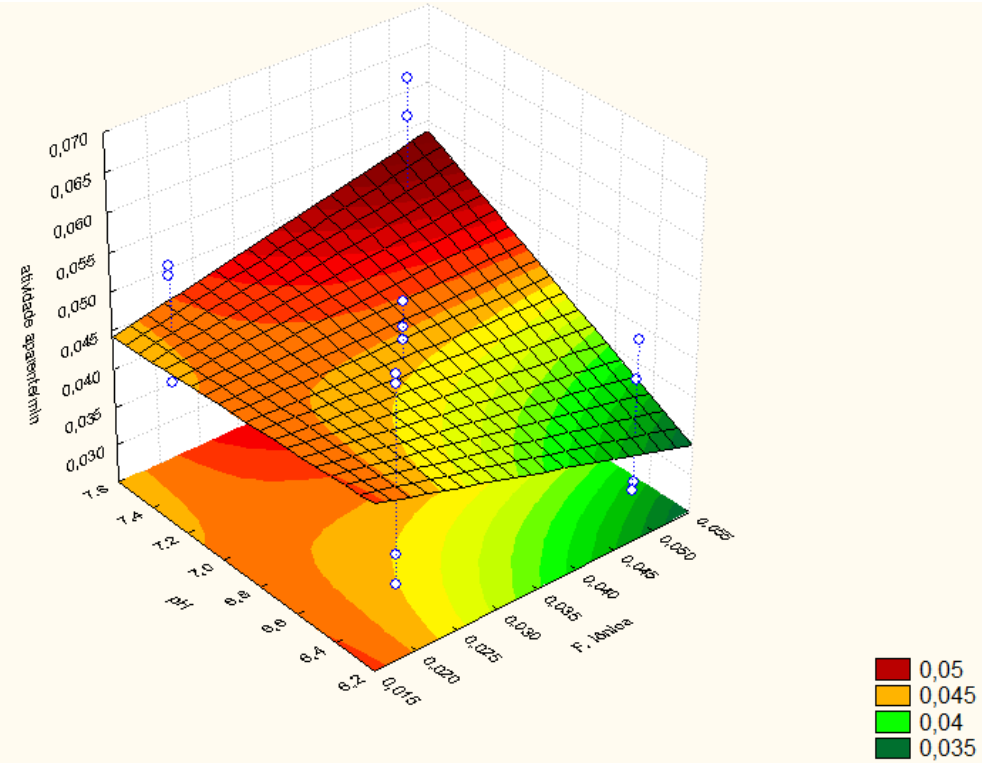

Figura 37 - Superfície de resposta do modelo de regressão linear para a atividade enzimática da AChE após 60 minutos de incubação na presença de de metil paration.

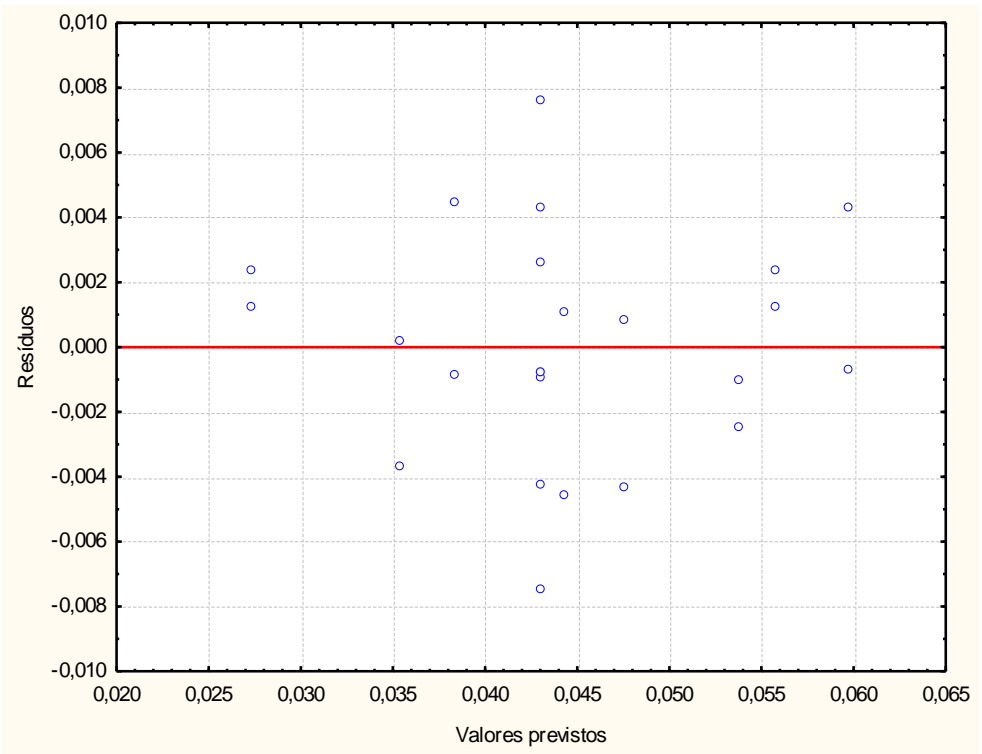

Figura 38 - Gráfico dos resíduos (valores previstos x resíduos) indicando o ajuste do modelo linear proposto. 


\subsubsection{6.}

Acefato

Os estudos indicaram que não foi encontrada nenhuma diferença de intensidade de fluorescência total da fração protéica na presença do organofosforado acefato quando comparado com o controle (fração protéica em tampão).

\subsection{3. \\ Aplicação da otimização com restrição}

Tendo obtido todos os modelos de regressão graficamente para o sinal fluorescência do sistema (fração protéica-analito), realizou-se a sobreposição das superfícies de resposta dos analitos através da funcão "desejabilidade". Uma representação gráfica para este caso é mostrada na figura 38. Este é um método de programação não-linear e, no caso do programa Statistica,que usa a abordagem de Derringer e Suich (1980), a ferramenta é a função “desirability”. Neste tratamento as respostas $\left(Y_{i}\right)$ são convertidas em uma outra função individual $d i$ que varia em uma faixa de $0 \leq d i \leq 1$. Se a resposta for aquela que se quer, $d_{i}=1$ e se a resposta estiver fora da região aceitável, $d_{i}=0$. Assim, as variáveis independentes são escolhidas de modo a maximizar a "desirability" global.

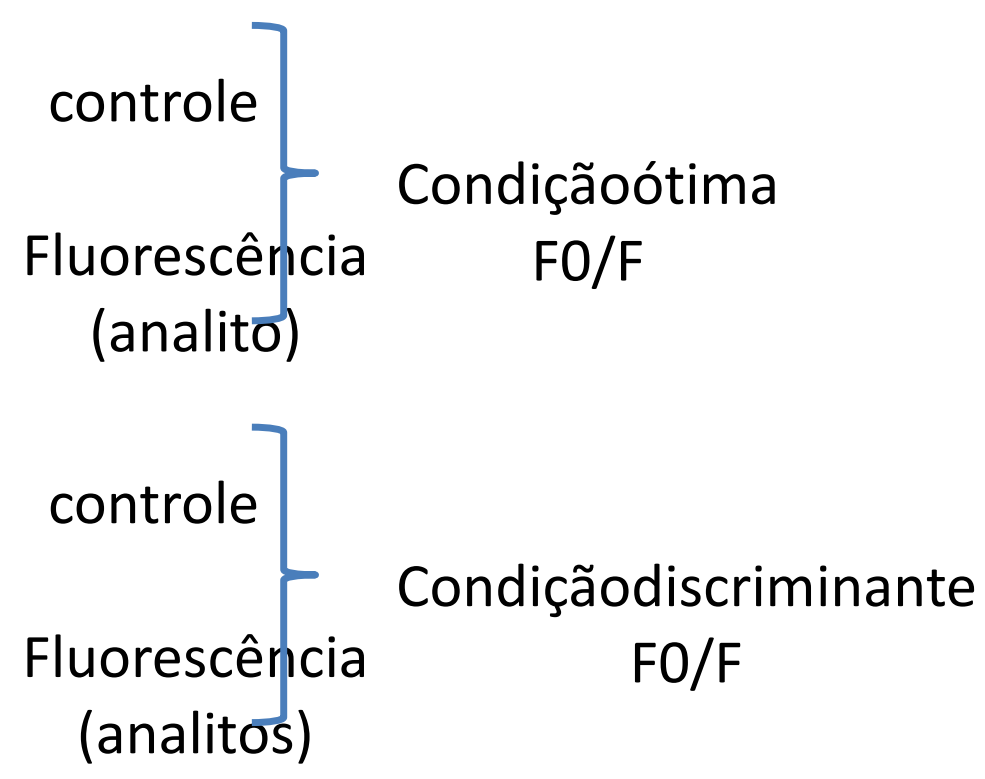


Figura 39 - Representação da sobreposição dos modelos gerados pelos planejamentos gerada pela função "desejabilidade".

\subsubsection{1.}

\section{Fluorescência}

Identificou-se domínios no gráfico do modelo de regressão onde a influência/interferência dos demais analitos é mínima. Neste caso, a região identificada é gerada pela sobreposição das superfícies de resposta do controle e de todas as superfícies de resposta na presença de cadaum dos analitos.

Para o caso de determinaçõesem sistemas com analitos já conhecidos, a medição de cada um deles pode ser feita nas condições ótimas individuaisdefinidas nos seus respectivos modelos. Para amostras desconhecidas, no entanto, deve-se recorrer a condições de menor interferência (que nem sempre é a condição ótima).

$\mathrm{Na}$ aplicação da "desejabilidade" deve-se ter cuidado com as faixas de resposta para cada analito no momento da sobreposição. Como a definição desta condição é qualitativa (maior ou menor resposta), na escolha da condição de maior sinal (interferentes) e menor sinal (analito), deve-se observar se a maior resposta de um modelo (interferentes) não coincide com a menor resposta dos demais modelos que serão sobrepostos (analitos). Dessa forma asseguramos que o resultado desta sobreposição definirá valores diferentes para a resposta de ambos.

A Figura 38mostra o gráfico com os valores previstos pelo modelo de regressão (superfície de resposta) para a intensidade de fluorescência de proteína total na presença dos analitos metomil, galantamina e atropina (avaliados separadamente) e o controle (somente a sonda). Ele mostra que, para todos os analitos, as faixas de sinal mínimo, médio e máximo são coincidentes. Assim, as respostas mínimas e máximas dos respectivos modelos não coincidem, o que inviabilizaria uma condição em que o sinal do analito de interesse seja majoritário na medição em reação aos interferentes. 


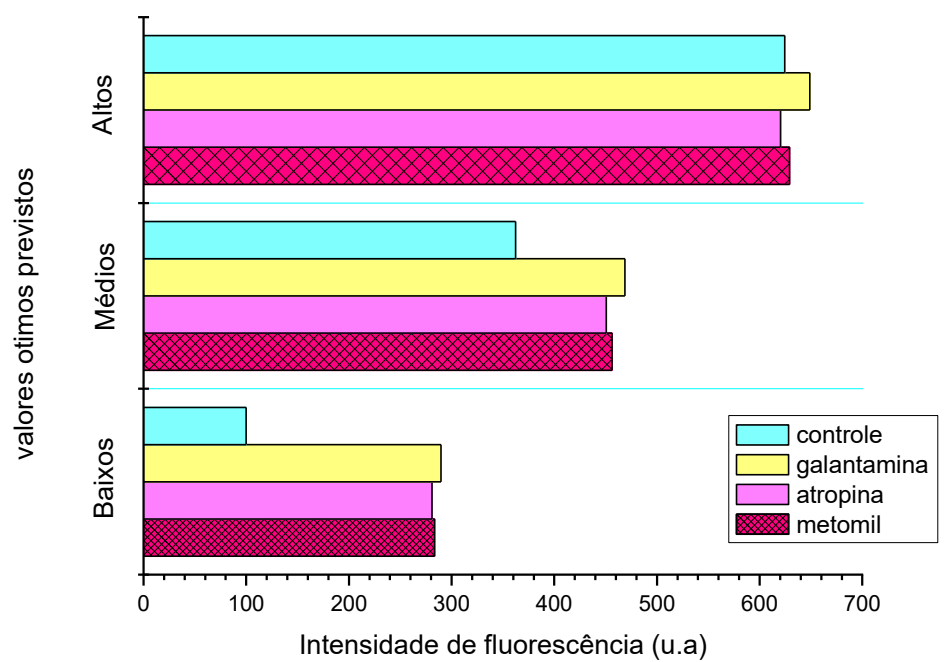

Figura 40 - Gráfico com os valores previstos pelo modelo de regressão para a intensidade de fluorescência de proteína total na presença dos analitos metomil, galantamina e atropina e seus controles.

$\mathrm{Na}$ Tabela 15, são apresentadas as condições para as três variáveis independentes geradas pela sobreposição dos modelos de regressão previstos para os analitos. Os valores experimentais mostrados se referem à condição de menor interferência dos demais analitos sobre a resposta de supressão de fluorescência da sonda.Observa-se que estas condições são muito próximas e isso impossibilita a separação da resposta da GAL da resposta da atropina, por exemplo. Para o metamidofós se identificou uma condição de $\mathrm{pH}$ um pouco mais ácida do que as demais Nessa condição deve-se observar a menor interferência dos demais analitos.

Tabela 15 - Resultado da função "desejabilidade" para a resposta de diminuição da fluorescência (fração protéica). 


\begin{tabular}{ccc}
\hline ANALITOS & $\mathbf{p H}$ & Força iônica \\
\hline Atropina & 7,2 & 0,02 \\
Galantamina & 7,3 & 0,01 \\
Metomil & 7,4 & 0,04 \\
Metamidofós & 6,3 & 0,03 \\
\hline
\end{tabular}

4.2.3.2.

Cinética

A atividade catalítica da AChE é influenciada pela presença de ativadores e também de inibidores. Sua cinética é a resultante desses diversos agentes em conjunto. Além disso, a AChE é uma proteína alostérica e por isso outros compostos, como o próprio substrato podem alterar sua atividade. Por conta dessas características não é possível discriminar a contribuição dos compostos considerados neste estudo visto que todos são ativos na faixa das condições experimentais testadas. No caso da fluorescência foram identificadas condições experimentais para discriminar seus efeitos por condições experimentais diferenciadas. Assim, o sinal medido teria a contribuição majoritária (quando não única) de uma determinada substância.Nos modelos de cinética enzimática obtidos, todos os analitos apresentam contribuições importantes na diminuição da atividade da AChE. Isto se deve à maior robustez da resposta da atividade cinética às diferenças experimentais do que o método baseado na fluorescência intrínseca da enzima.

\subsection{4.}

\section{Conclusão sobre os planejamentos}

Como conclusão geral a respeito dos resultados obtidos dos planejamentos, verificou-se que o aumento do tempo de incubação contribuiu positivamente no aumento da intensidade de fluorescência da fração protéica controle. Já na presença dos analitos GAL, metamidofós e metil paration, este fator exerce efeito inversoo que pode ser atribuído ao fato da capacidade de inibição da AChE por estes compostos depender do seu tempo de bioativação. O metamidofós e o metil paration 
são organofosforados que precisam passar por um processo de bioativação em sua molécula transformando-a na forma oxon ativa para se ligar ao sítio da enzima (verificado nos modelos de cinética). No caso da GAL, por ser esteum fraco inibidor colinesterásico, seu poder de inibição é aumentado somente após um tempo maior de contato maior com a enzima. Esses aspectos cinéticospodem explicar a dependência da dimiuição da fluorescência da fração com o tempo de incubação.

O metomil é o mais potente inibidor da $\mathrm{AChE}$ do grupo de analitos selecionados, com uma inibição da atividade enzimática in vitroquase instantânea. Atribui-se esta característica do metomilo fato do efeitode supressão de sinal causado por este analito na $\mathrm{AChE}$ não ser influenciado pelo tempo de incubação.

Os modelos de resposta fluorescente na presença dos analitos seguiram o mesmo padrão de superfície de resposta do controle (superfície com ponto de mínimo). Os ensaios de fluorescência com a fração protéica são reprodutivos, mostrando o mesmo comportamento do sinal(sob as mesmas condições) em dias diferentes e os modelos de cinética para o controle confirmaram a relevância das variáveis e sua relação linear com a atividade da AChE. As respostas na presença dos analitos provou a robustez dos ensaios de inibição enzimática nesta faixa experimental.

O modelo de inibição por metomil e GAL apresentou uma única variável relevante: o valor do $\mathrm{pH}$ para o metomil e o tempo de incubação para a GAL. Estas observações dos efeitos são coerentes com ensaios de inibição relatados na literatura $[250 ; 251]$.

Pelo resultado apresentado pelo planejamento experimental (baseado nas análises de variância e confirmado pelos resultadoscitados na literatura) pode se afirmar que a fração protéica obtida pode ser utilizada como sonda fluorescente na determinação dos analitos apresentados neste estudo.

\section{3.}

\section{Estudo espectroscópico das interações}

Após a otimização das condições de supressão de fluorescênciae inibição da AChE na presença dos analitos, realizou-se ensaios para tentar discutir a contribuição da enzima $\mathrm{AChE}$ na atenuação da fluorescência da fração protéica assim como nade outras proteínas.Os experimentos foram realizados com a fração 
de cérebro de rato assim como com o padrão a enzimaAChE (Electrophorus electricus) nas condições definidas nos planejamentos.

\subsection{1.}

\section{Estudos espectroscópicos preliminares: efeito filtro interno}

O efeito filtro interno refere-se à absorção da radiação deexcitação (préfiltro) e/ou absorção da emissão de um fluoróforo (pós-filtro) causando a diminuição de sua radiação detectada. Esse efeitogera uma diminuição do sinal fluorescente por conta da presença de substâncias com capacidade para absorver uma significativa quantidade de radiação incidente de excitação da sonda ou emitida pela sonda. Esta diminuição da fluorescência (que aumenta com a concentração da substância absorvente) induz à superestimação do valor da constante de supressão, também chamada de constante de Stern-Volmer (Ksv). A ocorrência deste efeito prejudica a robustez de métodos analíticos baseados no princípio de supressão.

Para contornar esse problema e efetivamente medir a queda de sinal causada pela atenuação estática ou dinâmica da sonda pela presença do analito, a abordagem mais simples é feita pela correção do efeito filtro. Isto é feito pela medição da absorvância, no comprimento de onda escolhido para excitaçãoda sonda e no escolhido para medir sua emissão assim como a absorvância do analito nas respectivas concentrações empregadas nos ensaios. Em seguida, aplicam-se esses valores de absorvância na Equação 3 para correção da intensidade de fluorescência.

$$
\mathrm{F}_{\text {corr }}=\mathrm{F}_{\mathrm{obs}} \text { antilog }\left(\mathrm{Abs}_{e x c}+\mathrm{Abs}_{e m}\right) / 2(3)
$$

Onde $F_{\text {corr }}$ é o valor corrigido de fluorescência, a $F_{o b s}$ é o valor medido de fluorescência, $\mathrm{Abs}_{(e x c) e ́}$ a absorvância no comprimento de onda de excitação, e $\operatorname{Abs}_{(e m)}$ é a absorvância no comprimento de onda de emissão.

A eliminação do efeito filtro torna a medida independente destes parâmetros de absorção do ligante. Ao mesmo tempo, esta correção depende das condições operacionais da medição de fluorescência. Várias abordagens de correção do efeito filtro foram propostas para atender diferentes condições experimentais nosestudos 
de eventos de supressão de fluorescência. Entretanto,a melhor maneira de eliminar a interferência desse efeito é assegurar que sua contribuição seja mínima, devendose procurar faixas de supressão sem a ocorrência de filtro. Nesse caso, recomendaseque as concentrações devem ser escolhidasde forma que a absorvânciado ligante adicionado seja inferior a $0,02 \operatorname{nos} \lambda_{\text {exc }}$ e $\lambda_{\text {em }}$ para não ser necessário corrigir as constantes de Stern-volmer (KSv) [256]. Tal procedimento, às vezes requer que os

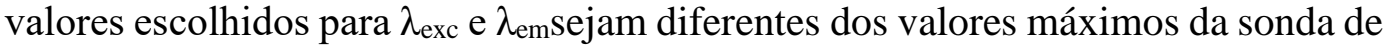
modo a operar fora das bandas de absorção dos ligantes. Essa escolha sacrifica sensibilidade em favor de seletividade.

Na Figura 39 são apresentados os espectros de absorção da fração protéica, na concentração de $0,06 \mathrm{mg} \mathrm{mL}^{-1}$, e também com o padrão purificado de $\mathrm{AChE}$ purificada. Na Figura 40 e 41, são apresentados os espectros de absorção dos analitos atropina, galantamina e metamidofós, respectivamentenas concentrações de $1,5 \times 10^{-7}, 2 \times 10^{-7}$ e $2,5 \times 10^{-7} \mathrm{~mol} \mathrm{~L}^{-1}$.Os valores de absorvância medidos em $280 \mathrm{~nm}$ e $340 \mathrm{~nm}$ indicam a ausência de efeito filtro sobre a resposta de supressão de fluorescência das frações protéicas. $\mathrm{O}$ pesticida metomil e metil paration não apresentam absorção na faixa de concentração utilizada nos testes de titulação.

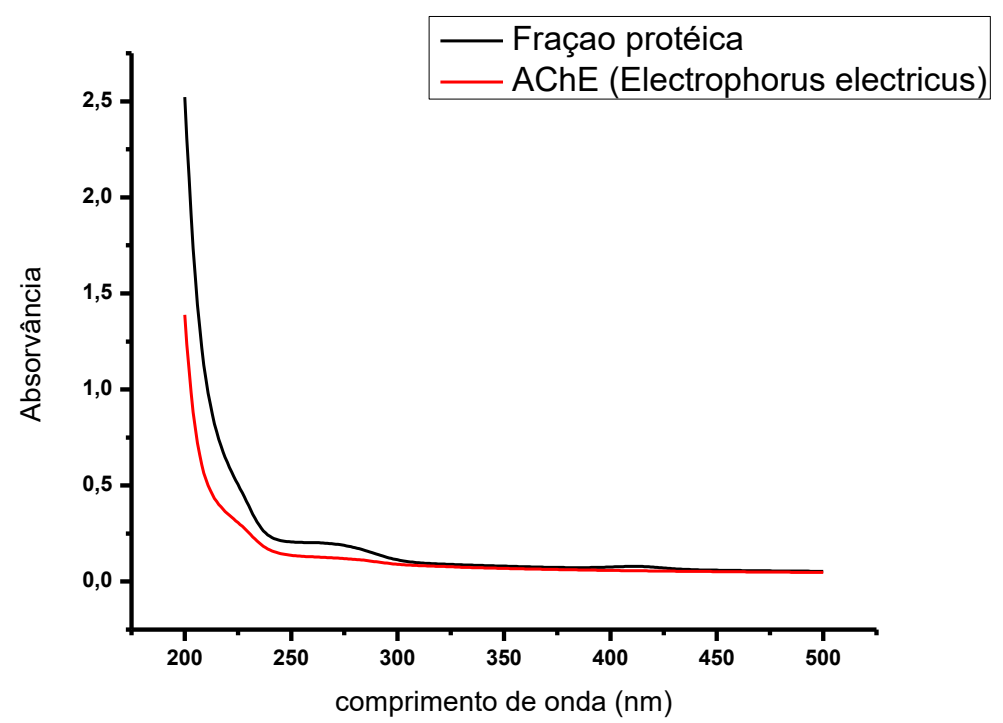

Figura 41 - Espectro de absorvância da AChE (Electrophorus electricus) e da fração proteíca (cérebro de rato) na concentração de $0,06 \mathrm{mg} \mathrm{mL}^{-1}$. 


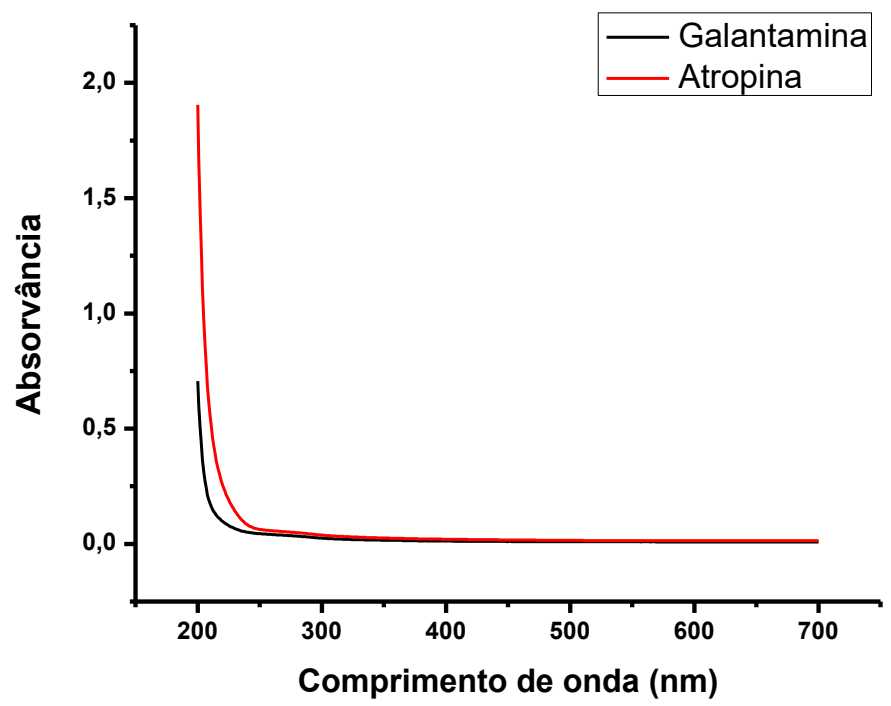

Figura 42 - Espectro de absorção de soluções dos analitos galantamina (2 x $\left.10{ }^{-7} \mathrm{~mol} \mathrm{~L}^{-1}\right)$ e atropina $\left(2 \times 10^{-7} \mathrm{~mol} \mathrm{~L}^{-1}\right)$.

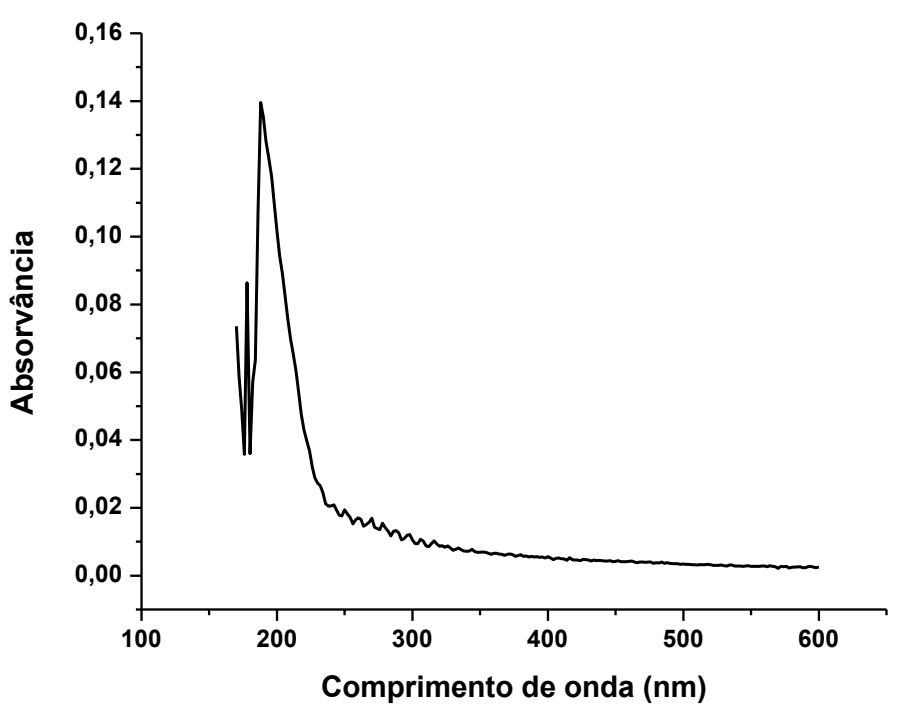

Figura 43 - Espectro de absorvância da solução de $\left(3 \times 10^{-7} \mathrm{~mol} \mathrm{~L}^{-1}\right)$ de metamidofós.

Neste trabalho considerou-se que a correção da constante de $\mathrm{K}_{\text {Sv }}$ pela absorvância do supressor (analito) é relevante mesmo quando esta é menor do que 
0,02 [256]. Para assegurar um valor real desta constante optou-se em realizar os ensaios em faixas de concentração otimizadas do fluoróforo e do analito, identificando a contribuição do efeito filtro. Para isso foram testadas três concentrações da fração do extrato que foram tituladas com atropina.

A Tabela 16 mostra os valores de $K_{S V}$ das curvas de supressão utilizando concentrações diferentes da fração protéica de rato (fluoróforo) empregando a atropina como supressor (faixa de concentração da curva de supressão: 2,0 x $10^{-8}$ à $\left.1,4 \times 10^{-7} \mathrm{molL}^{-1}\right)$. O objetivo desse estudo foi o de testar as concentrações de 0,03, 0,06 e $0,1 \mathrm{mg} \mathrm{mL}^{-1}$ de proteína total para os ensaios com fluorescência de modo a alcançar maior sensibilidade e contribuir para evitar a interferência do efeito filtro. Os valores de $\mathrm{K}_{\mathrm{SV}}$ para os três casos são indicados, mostrando que a concentração mais elevada do fluoróforo, como esperado,permitiu a maior sensibilidade da curvade supressão. Observa-se, pelos valores próximos de $\mathrm{K}_{\mathrm{SV}}$ obtidos para 0,06 $\mathrm{mg} \mathrm{mL} \mathrm{m}^{-1}$ e $0,1 \mathrm{mg} \mathrm{mL}^{-1}$, que o uso de concentrações mais elevadas de proteína do que as testadas não traria nenhuma vantagem do ponto de vista analítico.Nestas condições observa-se que as concentrações de proteína total entre $0,06 \mathrm{mg} \mathrm{mL}^{-1} \mathrm{e}$ $0,1 \mathrm{mg} \mathrm{mL}^{-1}$ são adequadas para os ensaios de supressão de fuorescência propostos neste trabalho.

Tabela 16 - Valores da constante Ksv determinados em 3 razões proteínas total/atropina.

\begin{tabular}{cccc}
\hline Atropina $\left(\mathrm{mol} \mathrm{L}^{-1}\right)$ & $\mathrm{Ksv}_{1}$ & $\mathrm{Ksv}_{2}$ & $\mathrm{Ksv}_{3}$ \\
\hline $2,0 \times 10^{-8}-1,4 \times 10^{-7}$ & $1,32 \times 10^{6}$ & $2,64 \times 10^{6}$ & $2,8 \times 10^{6}$ \\
\hline
\end{tabular}

\subsection{2.}

\section{Mecanismos de Supressão}

A dimimuição de fluorescência pode ser o reflexo de uma variedadede processos.A supressão colisional (dinâmica) ocorre quando ofluoróforo, no estado excitado, é desativado (por transferência de energia)após contatocom algumaoutra moléculaem solução (supressor). Neste caso, o fluoróforo retorna ao estado fundamentalsem modificação na estrutura química das moléculas envolvidas no processo. Por outro lado, adiminuição de fluorescência também pode ocorrerpela 
fomação de complexos estáveis não-florescentesentre o fluoróforo e a molécula supressora. Este mecanismo, denominado supressão estática, ocorreno estado fundamentale nãodepende da difusão e/ou colisõesmoleculares.Neste caso,a relação entre a intensidade de fluorescência e aconcentração do supressor é facilmente determinada pelo cálculo da constante de associação para a formação do complexo (Equação 4).

$$
K S V=\frac{[F-Q]}{[F][Q]}(4)
$$

onde $[\mathrm{F}-\mathrm{Q}]$ é a concentração do complexo, $[\mathrm{F}]$ é a concentração do fluoróforo não-complexado, e [Q] é a concentração do supressor (neste caso o analito). Se a espécie complexadanão emite fluorescência, então a fração de fluorescência remanescente $\mathrm{F}_{0} / \mathrm{F}$ é dada pela fração de fuoróforo total que não complexou. Considerando quea concentração total de fluoróforo $[\mathrm{F}]_{0}$ é dada pela Equação 5,após substituição dos termos,obtem-se a Equação 6.

$$
\begin{gathered}
{[F] 0=[F]+[F-Q](5)} \\
K s v=\frac{[F]}{[F][Q]}-\frac{[F]}{[F][Q]}=\frac{[F 0]}{[F][Q]}-\frac{1}{[Q]}(6)
\end{gathered}
$$

Ao substituir a concentração do fluoróforo pela intensidade de fluorescência, pode-se reorganizar a Equação 6 de modo a obter a Equação 7 que é a Equação de Stern-Volmer.

$$
\frac{F 0}{F}=1+K s v[Q]
$$

A relação entre a razãoF $/$ Fea concentração do supressor [Q] é linear sendo a constantede supressão própria constante de associação dos complexos.

Apenas a medida da diminuição da fluorescência não permite identificara contribuição dos processos (dinâmico e/ou estático) na resposta de atenuação fluorescente.A medição do tempo de vidade fluorescênciaéo método mais definitivo para distinguir entre esses dois mecanismos. A 
supressãoestáticaremoveuma fração dos fluoróforos da observação.Nesse caso a fluorescênciaobservada é apenas da fração não complexada (sem alteração no seu tempo de vida). Um método adicional para distinguir essas duas formas se supressão é através dos espectros de absorçãodo fluoróforo. A diminuição de fluorescência por colisões afeta apenasosestados excitados dos fluoróforos e, portanto, os espectros de absorçãonão se alteram. Entretanto, aformação do complexo (estado fundamental) pode resultar em nítidas alterações noespectro de absorçãodo fluoróforo.

Para distinguir os mecanismos de supressão de fluorescência da fração protéica, neste trabalho, utilizou-se a informação das curvas de temperatura,como descrito nos estudos de supressão de fluorescência [257].O mesmo ensaio na presença dos ligantes foi realizados em diferentes temperaturas para verificar alterações no valor de $\mathrm{K}_{\mathrm{Sv}}$. Considera-se que o aumento de temperatura perturbe as condições de ligação entre o fluoróforo e o ligante, desestabilizando a formação dos complexos. Dessa forma, o mecanismo de extinção de fluorescência por formação de complexo proteína-analito seria identificada pela diminuição da constante de ligação em temperaturas mais altas.

A seguir,são apresentadas as curvas de supressão de fluorescência pelo efeito de cada agente de supressão (analitos). As condicões do meio ( $\mathrm{pH}$ e força iônica do tampão) foram determinadas pelo modelo de regressão obtido na fase de planejamento experimental.

\subsubsection{1. Atropina}

A atropina é um fraco agente anticolinesterásico. Mesmo ligando-se fortemente à molécula de enzima $\mathrm{AChE}$, a atropina não age como um inibidor muito eficiente [258]. Ela compete com a acetilcolina para ligar-se ao sítio ativo da AChE [259]. Na Figura 42, os espectros do padrão de AChE purificado de Electrophorous electricus são mostradas ao longo da titulação com atropina até sua saturação. 


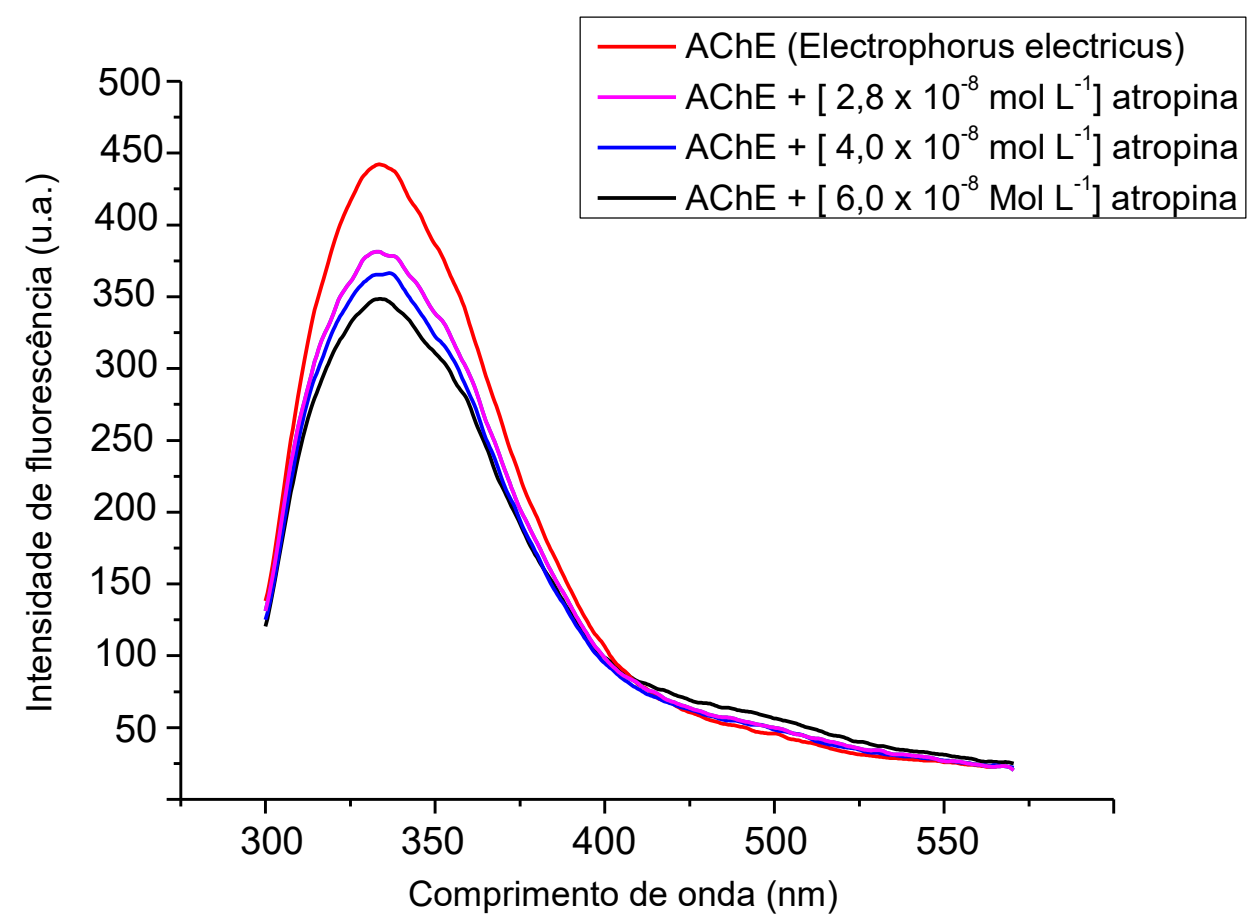

\section{Figura 44 - Espectro de emissão de fluorescência da AChE purificada após titulação com atropina até o ponto de saturação.}

Apesar da supressão causada na fluorescência da enzima, a atropina é uma molécula que emite fluorescência com pico em $285 \mathrm{~nm}$ (excitação em $255 \mathrm{~nm}$ ). Entretanto, nesta faixa de concentração sua fluorescência não causa interferências nas medidas de titulação.

Nas condições otimizadas observa-se o comportamento de supressão de fluorescência do extrato de proteína após adições sequenciais de $2 \times 10^{-8} \mathrm{~mol} \mathrm{~L}^{-1} \mathrm{de}$ atropina (Figura 43). Na comparação entre a curva de supressão de fluorescência intrínseca do padrão de AChE purificada e do extrato de cérebro, identifica-se a maior sensibilidade para a fração purificada na presença da atropina. Isto se deve a maior atividade específica na suspensão enzimática purificada titulada (Figura 43). Os valores de $\mathrm{K}_{\mathrm{SV}}$ para a supressão induzida por atropina no extrato e na fração de AChE purificada são, respectivamente, 2,71 x10 $\mathrm{L} \mathrm{mol}^{-1}$ e 4,54 x $10^{6} \mathrm{~L} \mathrm{~mol}^{-1}$. 


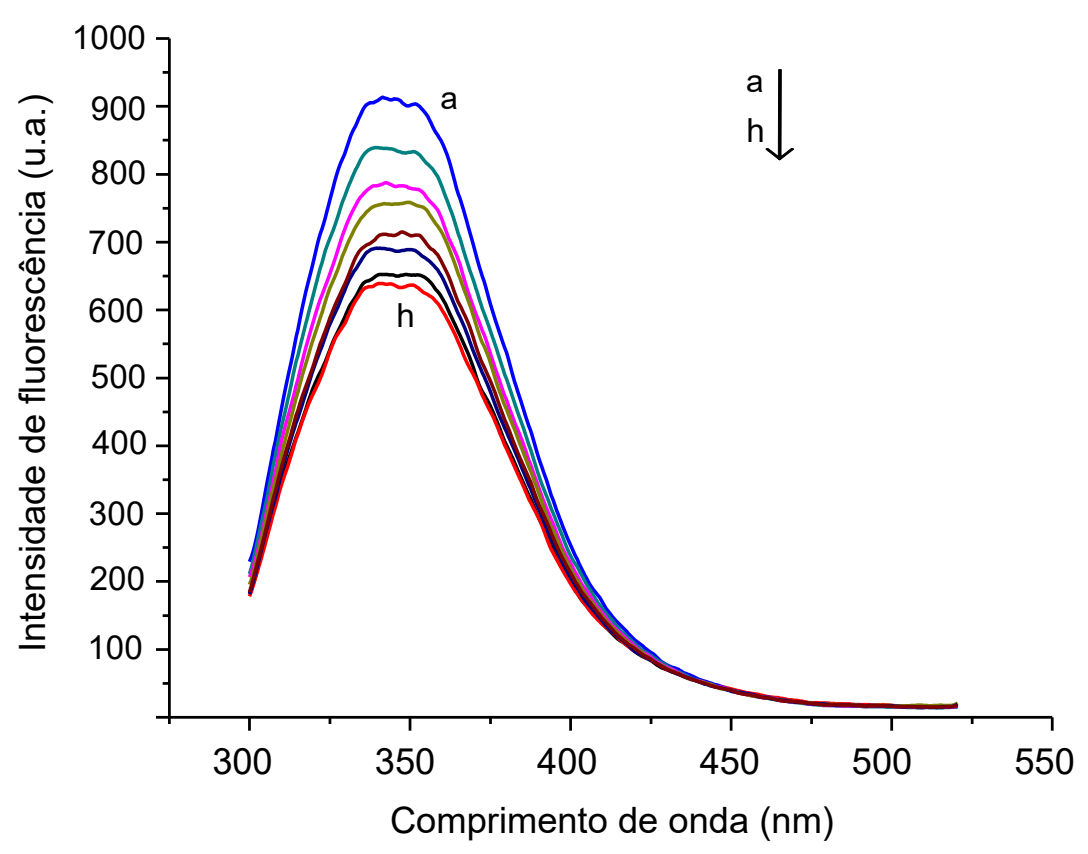

Figura 45 - Espectro de fluorescência das proteínas totais da fração de

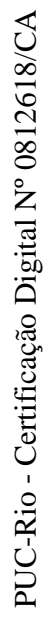
cérebro de rato durante titulação com atropina $\left(2 \times 10^{-8}\right.$ à $\left.1,4 \times 10^{-7} \mathrm{molL}^{-1}\right)$.

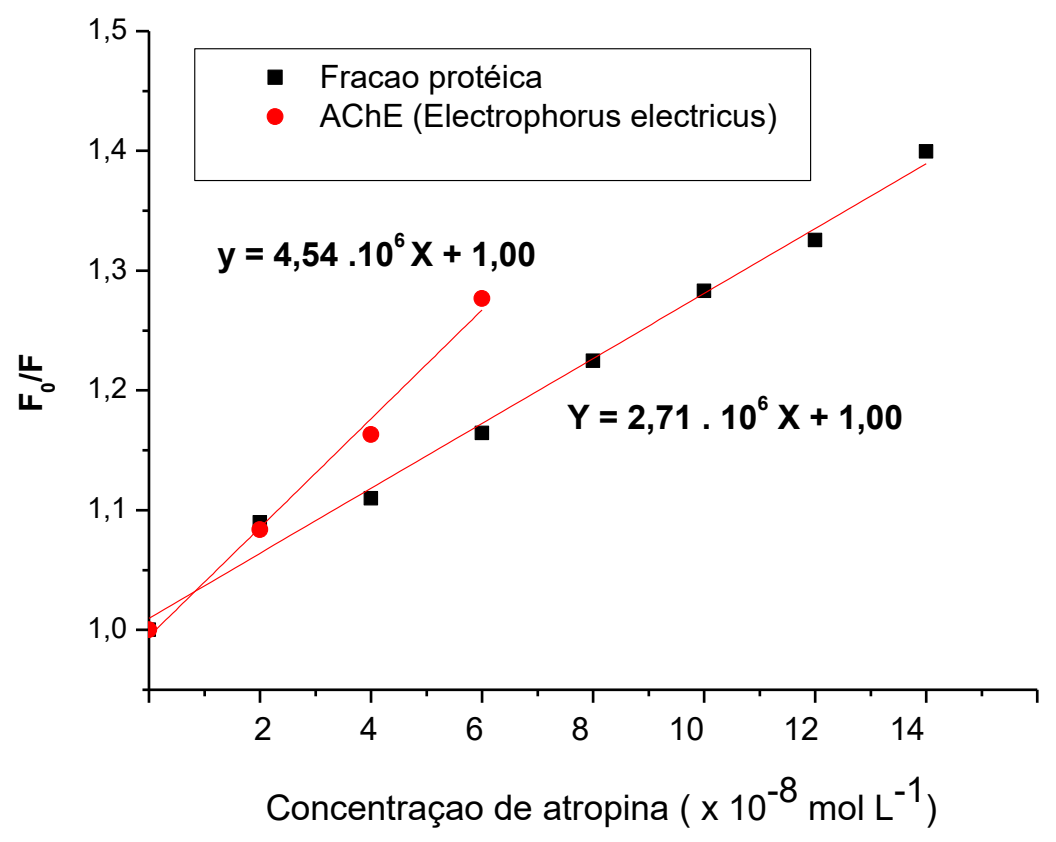


Figura 46 - Curvas de supressão de fluorescência da fração protéica do extrato de cérebro e da AChE purificada.

As curvas de Stern-Volmer para a supressão por atropina foram construídas em duas temperaturas $\left(27\right.$ e $\left.30^{\circ} \mathrm{C}\right)$ e são apresentada na Figura 44. Os resultados desse estudo indica que o mecanismo de supressão estática da fluorescência é o predominante visto que o valor de $\mathrm{K}_{\mathrm{SV}}$ diminiu com o aumento da temperatura como mostrado na figura 45 .

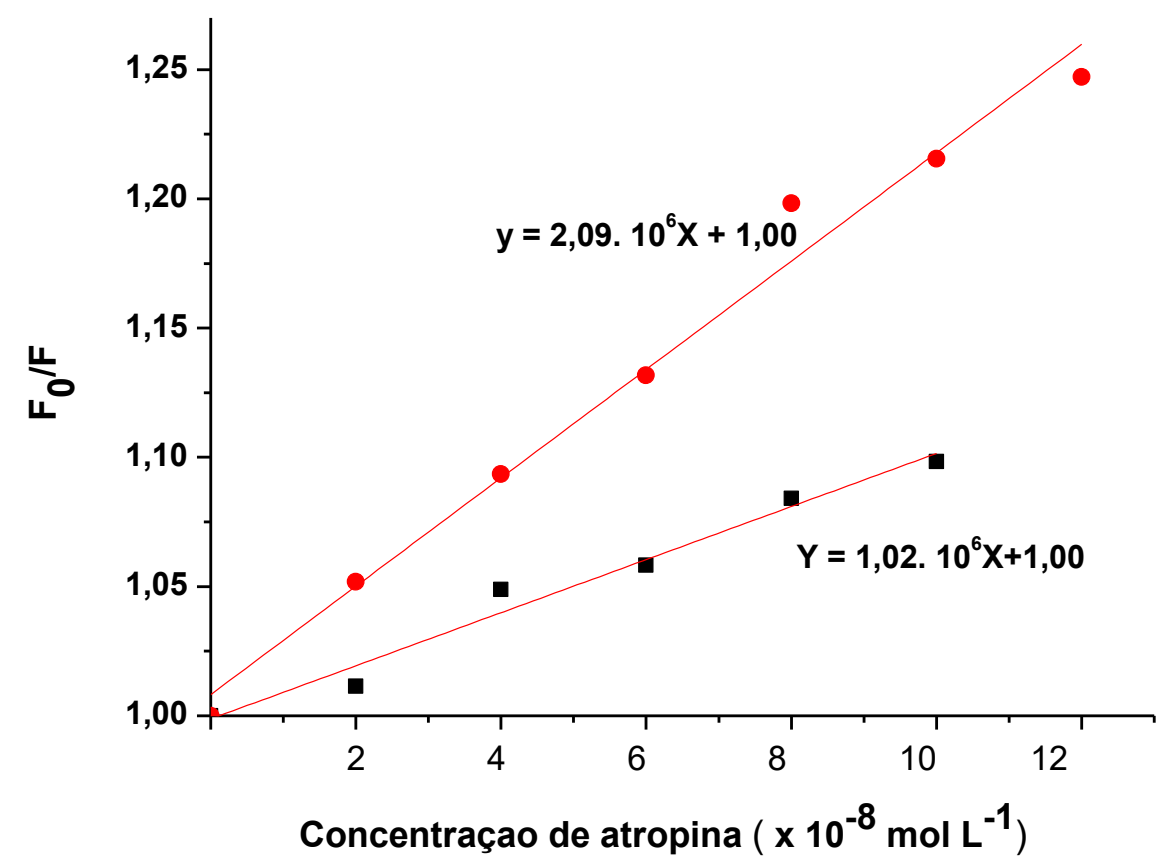

Figura 47 - Gráfico de Stern-Volmer mostrando a diferença na afinidade de formação de complexos com a atropina em duas temperatura ( 27 $\left.{ }^{\circ} \mathrm{C} \mathrm{e} 30^{\circ} \mathrm{C}\right)$.

A literatura apresenta alguns métodos clássicosque utilizamdados de fluorescência para determinar o número deequivalentesde sítios de ligação por proteína $[260 ; 261 ; 262]$. Um dos tratamentomais utilizados baseia-seem um gráfico quepermite calcular, a partir da inclinação, o número de moléculas do supressor que interagem simultaneamente com cada sítio. Esta inclinação do gráfico indica a estequiometria do complexo proteína-supressor. Portanto, considerou-se que tais 
expressões são úteis para determinar a estequiometria do processos de ligação [263].

Por esta abordagem, a relaçãoentre a intensidadede extinção de fluorescênciae da concentração do supressorpode ser descrita como indicado na Equação 8:

$$
\log _{10}\left\{\left(\mathrm{~F}_{0}-\mathrm{F}\right) / \mathrm{F}\right\}=\log _{10} \mathrm{~K}_{\mathrm{a}}+\mathrm{n} \log _{10}[\mathrm{Q}](8)
$$

Onde $\mathrm{K}_{\mathrm{a}}$ é aconstante de ligação ou a constante de associaçãoda interação,e né o número denúmero de moléculas do supressor que interagem simultaneamente com cada sítio ligante.

Na Figura 46 é mostrado o gráfico de duplo log para a titulação da fração protéica com atropina. Através da regressão identificamos que os complexos proteína-atropinatem estequiometria do tipo 1:1.

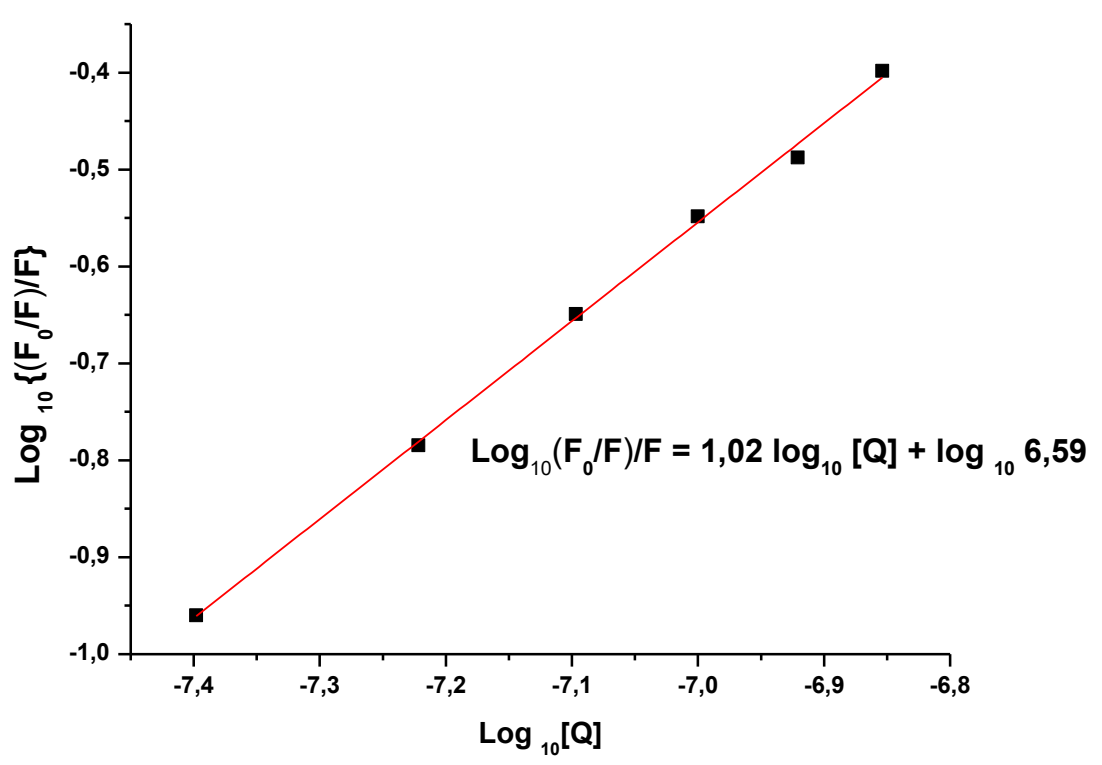

Figura 48- Gráfico log-log da supressão da fluorescência da $\mathrm{AChE}$ purificadaem titulação com atropina $\left(2 \times 10^{-8}\right.$ à $\left.1,4 \times 10^{-7} \mathrm{~mol} \mathrm{~L}^{-1}\right)$.

\subsubsection{2.}

\section{Galantamina}


A GAL é um fraco inibidor da AChE e compossível potencial alostérico sobre os receptores nicotínicos de acetilcolina (nAChR) [264;265].A estruturade raios-Xmostra umaorientação particular da galantamina no interior do sítio ativo da AChE, incomum para as interações proteína-ligante. A GAL liga-se à este sítio ativo e interage como "acil-pocket" com o principal local de ligação dos grupos amônioquaternário. No entanto, o grupo de amina terciária de GAL não interage diretamente com Trp84 próximo ao centro ativo [266].

A descrição da interação AChE-GAL cita que o anel de ciclo hexeno e os dois grupos metilenono anel tetrahidroazepina da molécula de galantamina estão virados parao anel indol doTrp84 [266]. Na Figura 47 tem-se o espectro de fluorescência da AChE purificada após titulação com $\operatorname{GAL}\left(1,7 \times 10^{-8} \mathrm{~mol} \mathrm{~L}^{-1}\right)$. Este comportamento de diminuição na emissão de fluorescência é esperado após sua interação com os sítios da AChE. Nota-se também que a estrutura geral do complexo TcAChE-GAL não exibe alterações conformacionais significativas quando comparado coma estrutura da enzima livre assim como relatado na literatura $[266 ; 267]$.

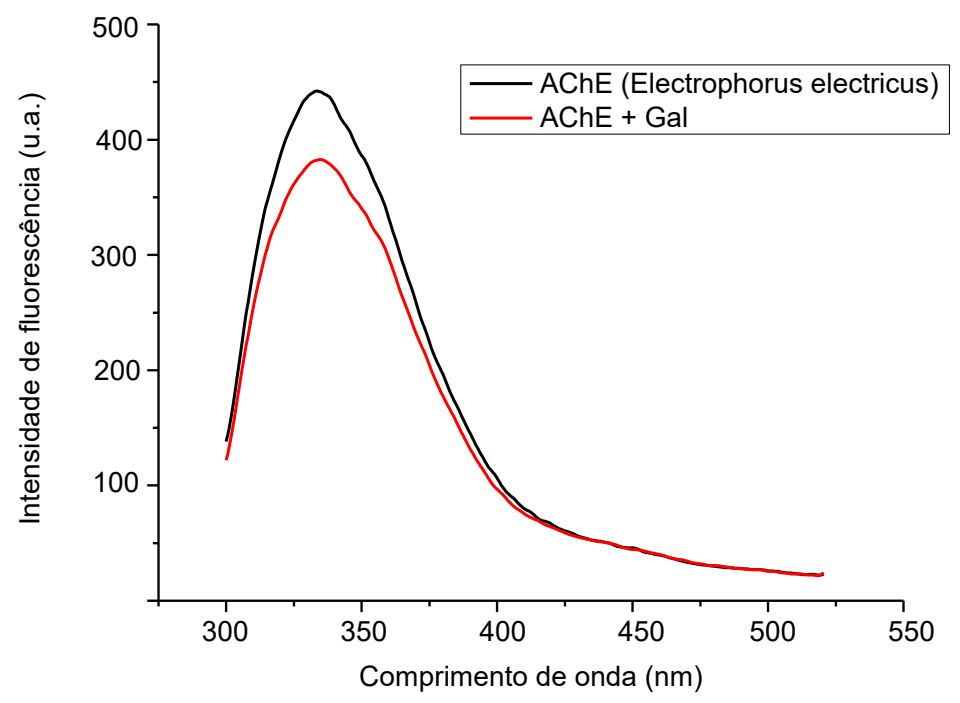

Figura 49 - Espectro de emissão de fluorescência da AChE purificada após titulação com $1,7 \times 10^{-8} \mathrm{~mol} \mathrm{~L}^{-1}$. 
A molécula de galantamina emite fraca fluorescência na faixa de emissão dos triptofanos (280/345 nm). Entretanto, afaixa de concentração de GAL utilizada não mostrasinal fluorescente detectável.

Recentemente foi descrita uma nova classe de ligantes dos nAChR que atuam comoativadoresdas respostasinduzidas porseus agonistas competitivos. A GAL é um membro desta classe agindo através de um sítio de ligaçãona molécula dos nAChR em um local distinto do sítio de ligação do neurotransmisor (acetilcolina) [268].A capacidadeda GAL em se ligar a eles é determinada principalmente pelos resíduos de triptofanos [269].

Após essa ligação, as moléculas dos receptorescolinérgicosmostramgrandes mudanças nafluorescência emitidapelos cinco triptofanos sem cada uma de suas subunidades, proporcionando um sistema de detecçãointrínsecopara monitorara estequiometria e cinética de ligantes [266]. A estequiometria da ligação receptorligante foi estimada a partir da supressão da fluorescência do triptofano dos receptores através de titulação com ligantesde alta afinidade [268;270;271].

O mecanismo de supressão não é conhecido para ligantes que, como a GAL „não possuem sobreposição espectral com a emissão de fluorescência dos resíduos de triptofano. Esta é uma exigência para que ocorra o fenômeno de transferência de energia por ressonância (FRET). No entanto, dois ou três dos cinco triptofanos existentes são encontrados na proximidade dos ligantes [272]. Da mesma forma, foi verificada a supressão de fluorescência da $\mathrm{AChE}$ após a ligação com compostos que não possuem capacidade para FRET [273]. Neste caso, o local de ligação é no sítio que contém os resíduos aromáticos.

Na Figura 48 é mostradaa diminuição de fluorescência da fração de protéica pela titulação com GAL. Pela composição da fração obtida de tecido cerebral, considerou-se que a concentração de saturação da fluorescência pela GAL se deve a presença concomitante da fração de $\mathrm{AChE}$ e de receptores colinérgicos (nACh) como os que se ligam à GAL. 


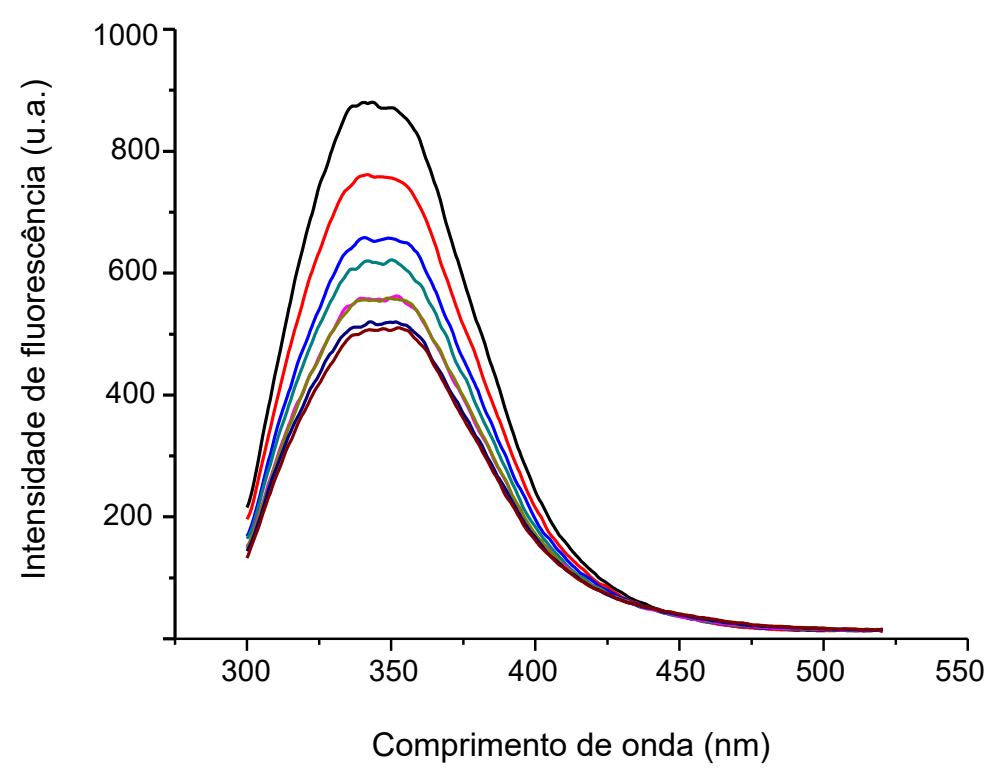

Figura 50 - Espectro da fração protéica titulada com galantamina na faixa de $1,7 \times 10^{-8} \mathbf{a ̀ ~} 1,2 \times 10^{-7} \mathrm{~mol} \mathrm{~L}^{-1}$

A Figura 49 representa a curva de Stern-Volmer para a titulação do extrato com GAL. O último ponto $\left(1,0 \times 10^{-7} \mathrm{~mol} \mathrm{~L}^{-1}\right)$ é o de saturação do sinal de fluorescência. $\mathrm{O}$ valor da constante de ligação $\left(\mathrm{K}_{\mathrm{SV}}\right)$ foi de 5,7 x $10^{6} \mathrm{~L} \cdot \mathrm{mol}^{-1}$.

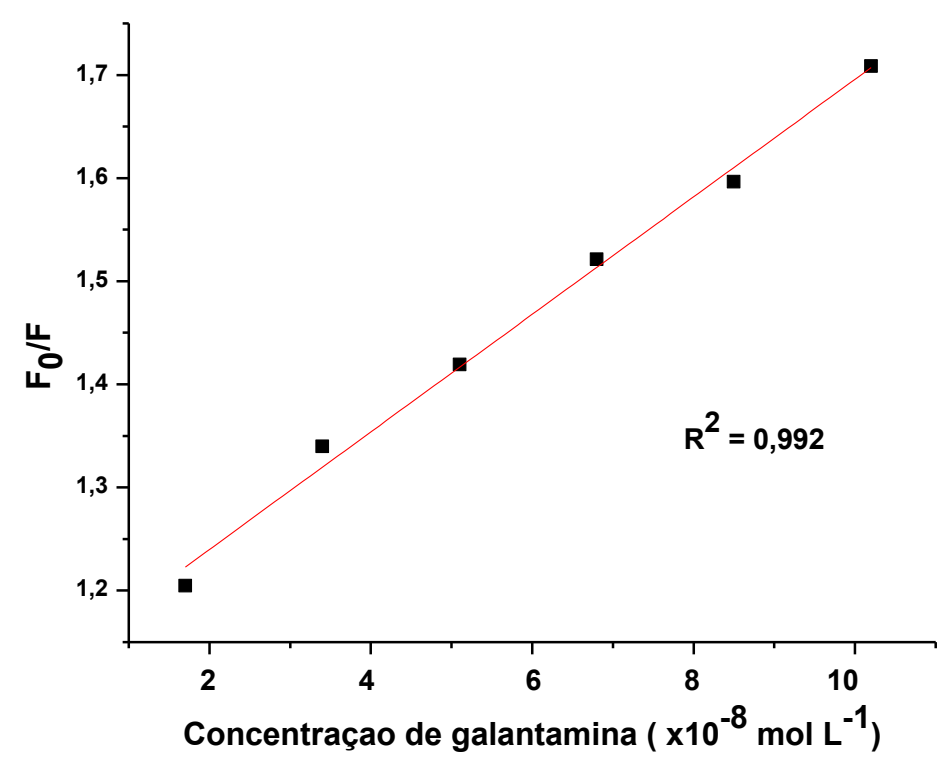

Figura 51 - Curva de supressão de fluorescência da fração protéica em titulação com galantamina $\left(1,7 \times 10^{-8}\right.$ à $\left.1,0 \times 10^{-7} \mathrm{~mol} \mathrm{~L}^{-1}\right)$. 
Considerou-se a supressão de fluorescência dos resíduos aromáticos, presentes na estrutura de ambas proteínas, como consequencia da formação dos complexos AChE-GAL e nAChR-GAL. Por isso realizou-se os ensaios de titulação sob diferentes temperaturas para verificar os valores das constantes de ligação para a fração de extrato. A Figura 50 indica que a partir de $27{ }^{\circ} \mathrm{C}$ (incluindo 30 e $34^{\circ} \mathrm{C}$ ) a afinidade pela GAL diminui severamente se comparada com o processo a $24{ }^{\circ} \mathrm{C}$. Esses dados evidenciam o mecanismos de supressão de fluorescência das proteínas desse sistema pela formação de um complexo com a GAL.

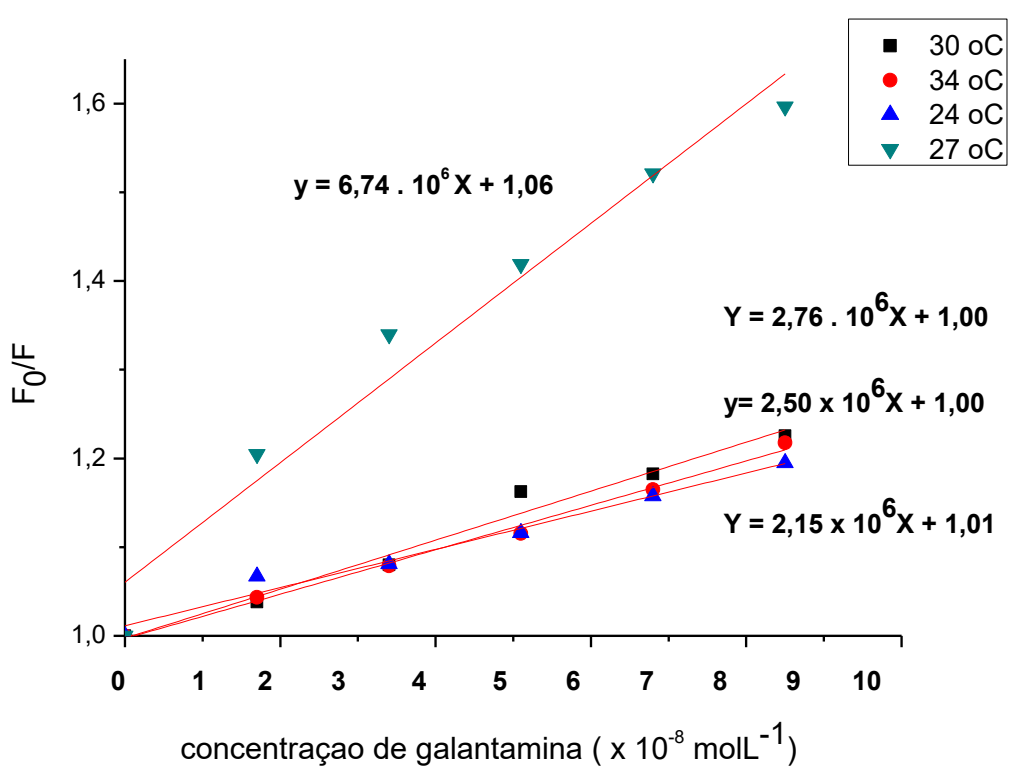

Figura 52 - Curva de supressão de fluorescência da fração protéica em 4 temperaturas $\left(24^{\circ} \mathrm{C}, 27^{\circ} \mathrm{C}, 30{ }^{\circ} \mathrm{C}\right.$ e $\left.34^{\circ} \mathrm{C}\right)$.

O complexo formado com a GAL é do tipo 1:1 como calculado através do gráfico log-log (Figura 51) e como é descrito para sua ligação com a AChE e com a fração de receptores da acetilcolina [274]. 


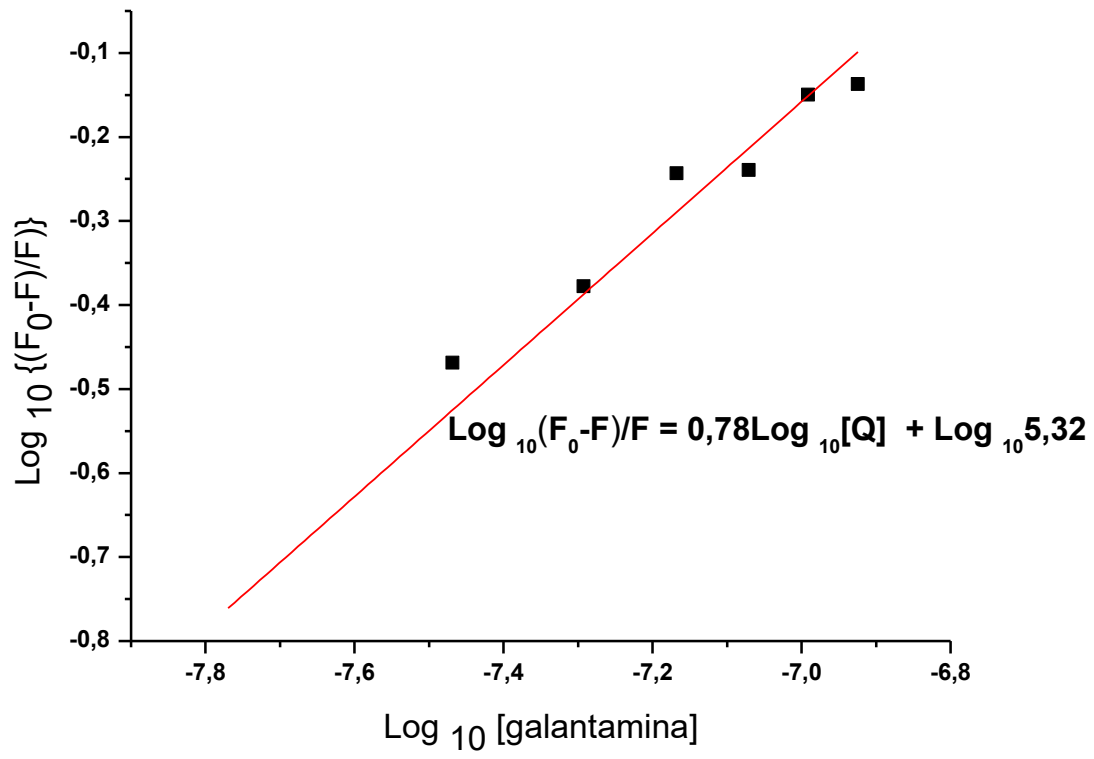

Figura 53 - Gráfico de log-log da curva de supressão da fração protéica pela Galantamina $\left(1,1 \times 10^{-8}\right.$ à $\left.1,0 \times 10^{-7} \mathrm{~mol} \mathrm{~L}^{-1}\right)$

\subsubsection{3. Metomil}

Os carbamatos como o metomil inibem a atividade da AChE pela carbamilação em seu centro ativo [275;276;277]. A fluorescência intrínseca da enzima (Electrophorus electricus) é fortemente suprimida pela sua ligação com carbamatos como foi relatado para o carbaril e aldicarbe [278]. Entretanto, a mesma supressão de fluorescência não foi observada no ensaio com a AChE purificada em titulação com metomil (Figura 52).. Essa discrepância pode ser explicada pelas diferenças entre as isozimas, já comentada na discussão do processo de extração da proteína.Este mesmo comportamento foi observado com o metamidofós (organofosforado). 


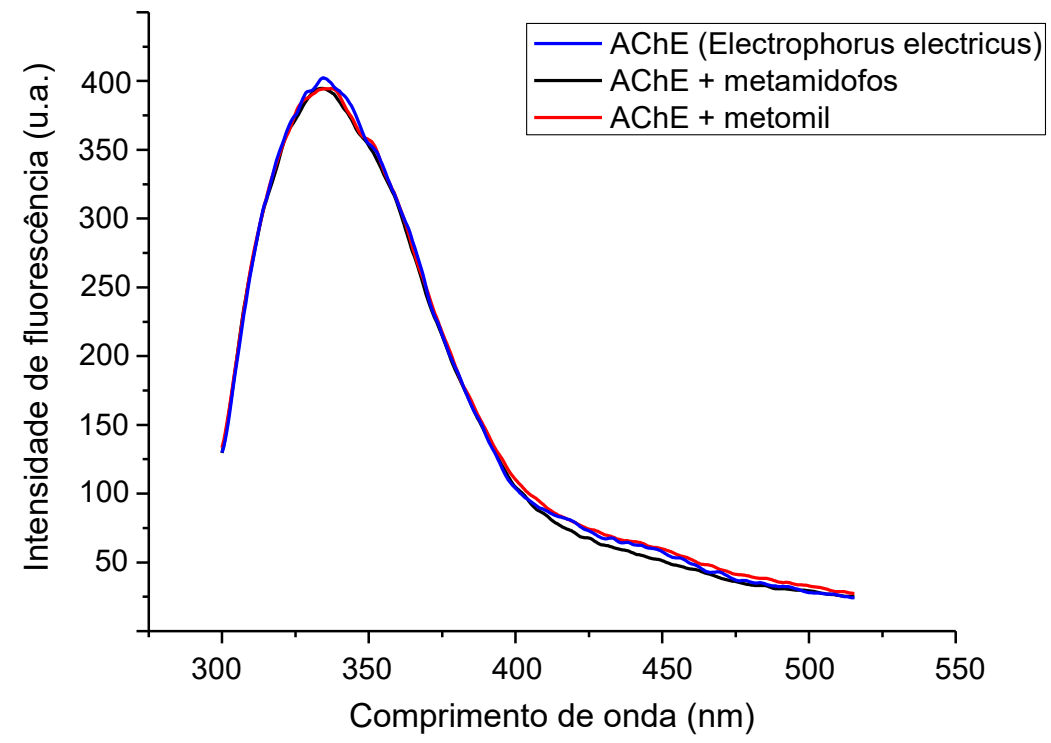

Figura 54 - Espectro da AChE purificada antes e após adição de [2,5 x

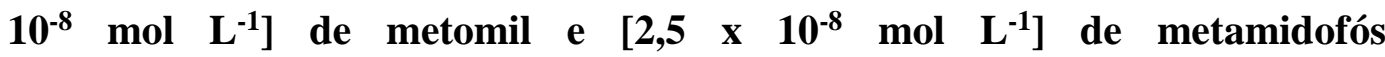
(organofosforado)

Para o ensaio de fluorescência feito com a fração protéica, a faixa de metomil usada na titulação provocou uma diminuição da fluorescência como mostrado na Figura 53. O ponto de saturação da fluorescência foi observado na concentração de $1,2 \times 10^{-7} \mathrm{~mol} \mathrm{~L}^{-1}$ do carbamato. 


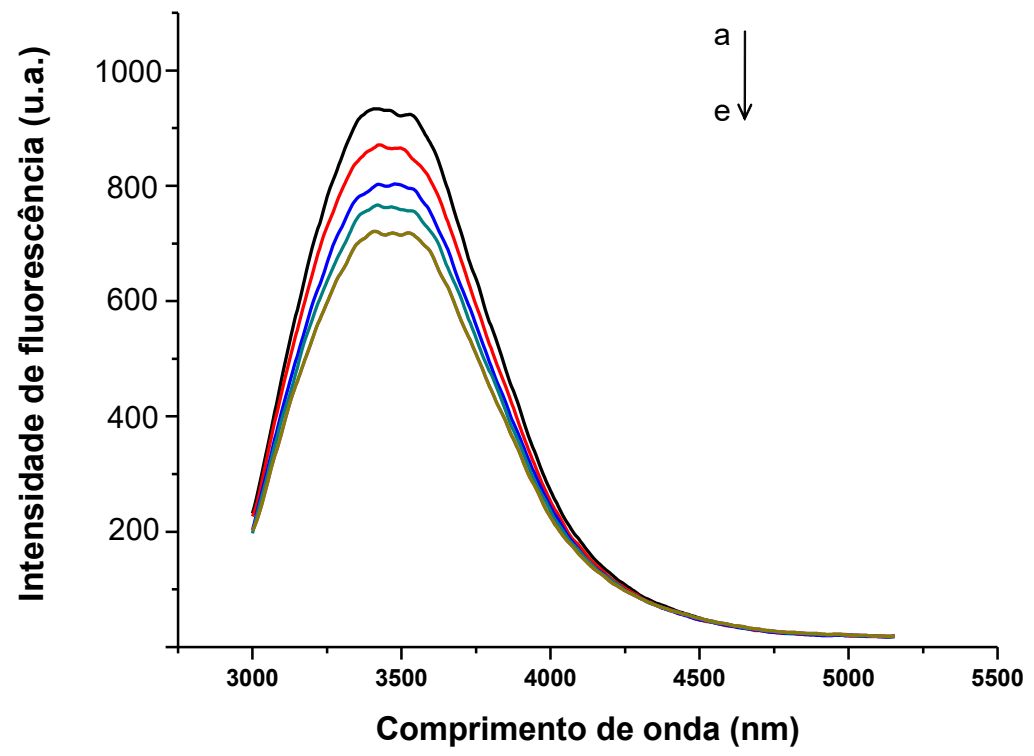

Figura 55 - Espectro da fração de cérebro de rato durante titulação com metomil $\left(2,5 \times 10^{-8}\right.$ à $\left.1,2 \times 10^{-7} \mathrm{~mol} \mathrm{~L}^{-1}\right)$.

A curva de Stern-Volmer (Figura 53) indica o KSV de 2,5 x $10^{5} \mathrm{~L}_{\mathrm{S}} \mathrm{mol}^{-1}$ para a formação do complexo AChE-metomil com proporção estequiométrica de 1:1 para a fração de AChE presente no extrato e no agrotóxico (Figura 55).

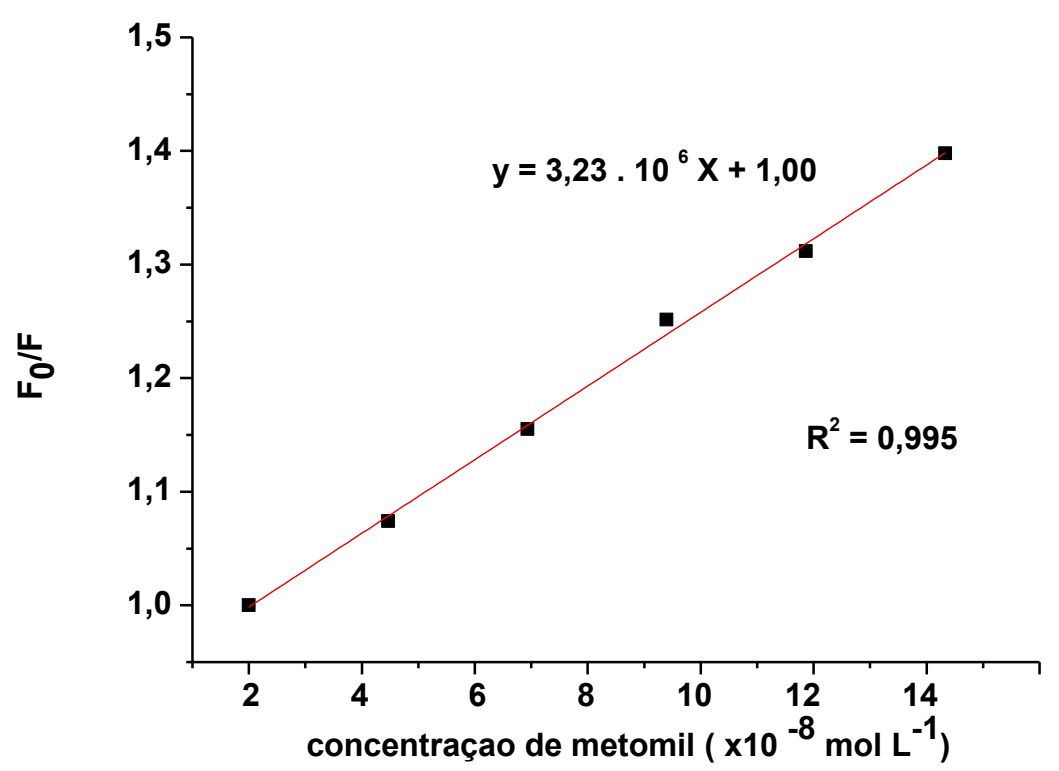

Figura 56 - Curva de supressão de fluorescência da fração protéica durante titulação com metomil $\left(2,5 \times 10^{-8}\right.$ à $\left.1,2 \times 10^{-7} \mathrm{~mol} \mathrm{~L}^{-1}\right)$. 


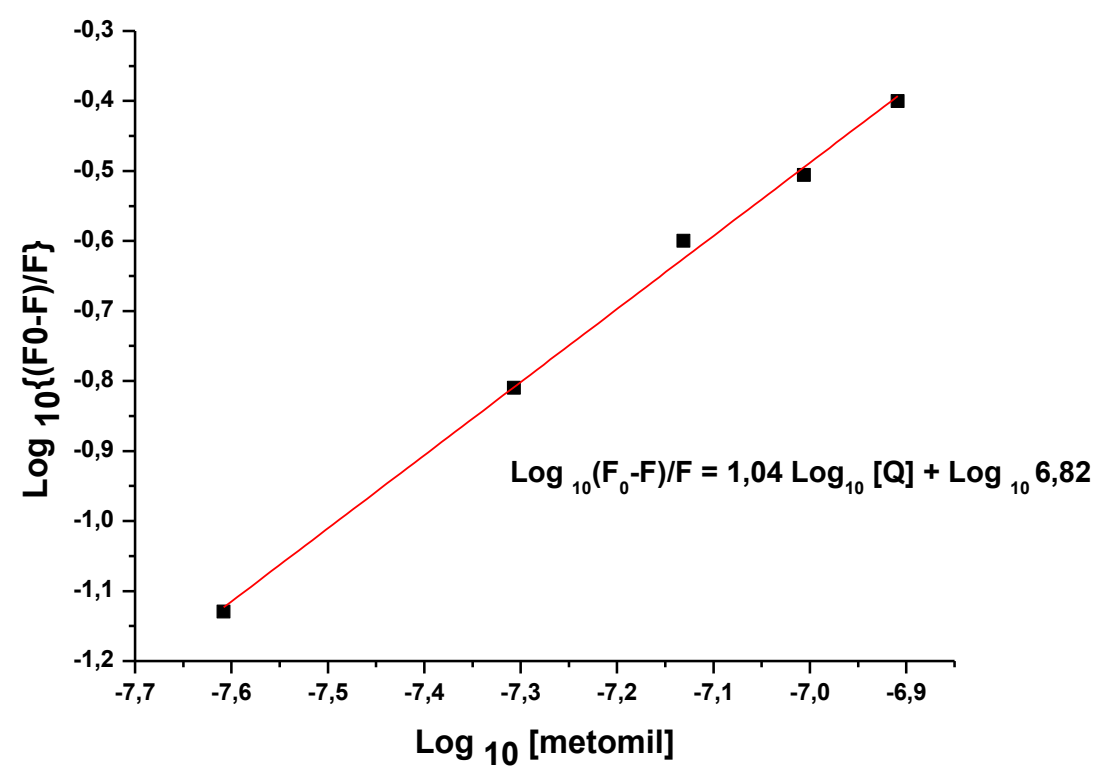

Figura 57 - Gráfico de log-log da curva de supressão da fração protéica por metomil.

\subsubsection{4. Metamidofós}

O processo de inibição da atividade da $\mathrm{AChE}$ envolve algumas etapas que culminam na fosforilação do resíduo de serina (Se200) presente neste sítio [279]. A falta de estudos envolvendo a fluorescência intrínseca da $\mathrm{AChE}$ e sua resposta à ligação com organofosforados impossibilitou a comparação com os resultados obtidos neste estudo. A titulação da $\mathrm{AChE}$ purificada com metamidofós não mostrou nenhuma alteração espectral da enzima(o mesmo que aconteceu como metomil, ver Figura 52). Isso indica que não houve interação ou não ocorreu alteração na emissão de fluorecência nos resíduos de triptofano próximos ao centro ativo da enzima ou aos sítios alostéricos de ligação com afinidade pelos organofosforados. Entretando, a fração de extrato de cérebro de rato apresentou supressão de fluorescência após titulação com metamidofós (Figura 56). Em experimentos in vitro com ratos, foi demonstrado que a molécula de acefato (pesticida organofosforado) é convertida à metamidofós no cérebro e no fígado.A formação de metamidofós foi observada nas respectivas frações microssomais 
desses órgãos [279]. Além disso, foram relatados resultados de inibição pororganofosforados (metamidofós e metil paration) na fração de $\mathrm{AChE}$ de preparações de cerebro de ratos [279]. Portanto, considerou-se que a fração protéica de cérebro obtidas neste trabalho contém espécies que promovem a transformação dos organofosforados a formas anticolinérgicas ativas. Assim, a ligação com a AChE pode gerar uma diminuição da emissão de fluorescência dos resíduos envolvidos nos sítios de ligação.

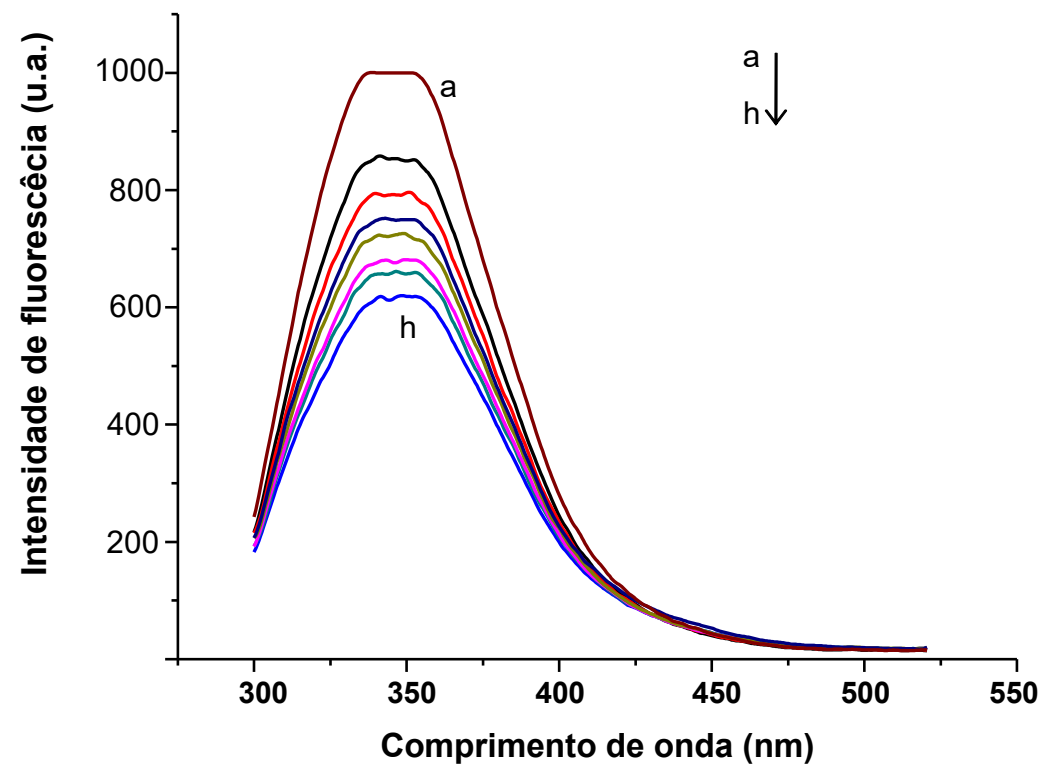

Figura 58 - Espectro de fluorescência da fração de cérebro de rato durante titulação com $\left(3,5 \times 10^{-8}\right.$ à $\left.2,5 \times 10^{-7} \mathrm{~mol} \mathrm{~L}^{-1}\right)$ de metamidofós.

A curva de Stern-Volmer mostra um valor de $\mathrm{K}_{\mathrm{Sv}}$ para a substância organofosforada igual a 2,05 x $10^{6} \mathrm{~L} \cdot \mathrm{mol}^{-1} \mathrm{O}$ aspecto linear da curva indica a presença de apenas um tipo de mecanismo de supressão (Figura 57). Neste caso considerou-se a formação de complexo entre a forma bioativa do pesticida e a AChE presente na preparação. Já a titulação feita com metamidofós em duas temperaturas mostrou a diminuição da afinidade proteína-metamidofós refletindo em um valor menor da $\mathrm{K}_{\mathrm{Sv}}$ na maior temperatura $\left(34^{\circ} \mathrm{C}\right)$ (Figura 58 ). 


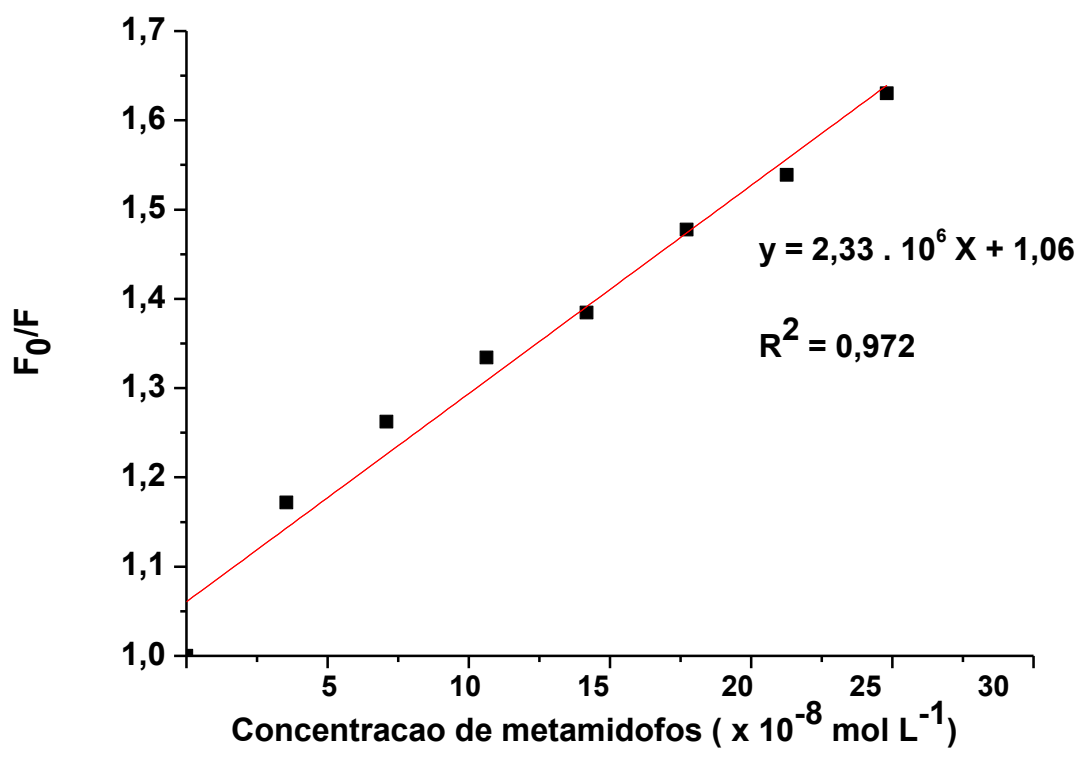

Figura 59 - Curva de supressão da fluorescência da fração protéica de cérebro por metamidofós $\left(3,5 \times 10^{-8}\right.$ à $\left.2,5 \times 10^{-7} \mathrm{~mol} \mathrm{~L}^{-1}\right)$.

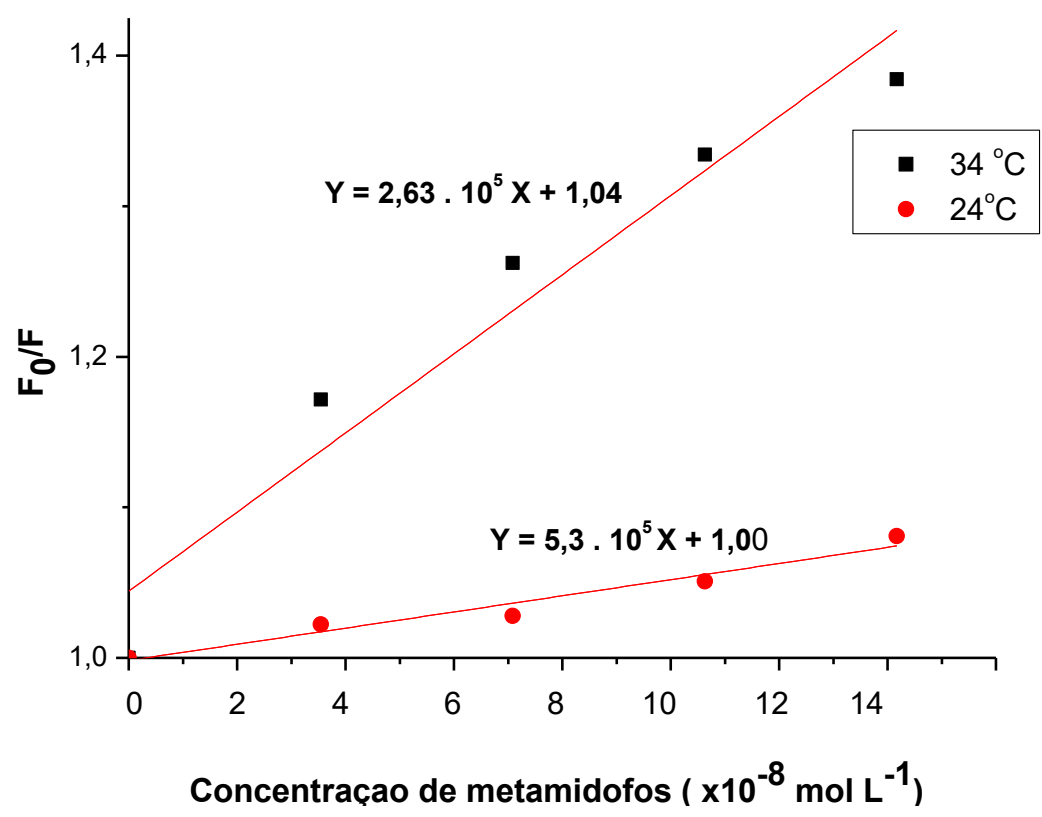

Figura 60- Curva de supressão de fluorescência do extrato em duas temperaturas $\left(24\right.$ e $\left.34^{\circ} \mathrm{C}\right)$. 
O tratamento de regressão indicado na Figura 59, mostraem sua inclinação, o número demoléculas do supressor que interagem simultaneamente comcada sítio fluorescente. Neste caso, com um valor de 0,6 sugere que a maior concentração titulada $\left(2,5 \times 10^{-7} \mathrm{~mol} \mathrm{~L}^{-1}\right)$ de metamidofós não saturou os sítios disponíveis na fracão de AChE. Este efeito pode ser causado pelo tempo de titulação insuficiente para que ocorresse a máxima complexação. Isso é corroborado pelo fato do efeito do metamidofós sobre a cinética assim como na extinção da fluorescência são dependentes do tempo de incubação (como mostrado no planejamento experimental).

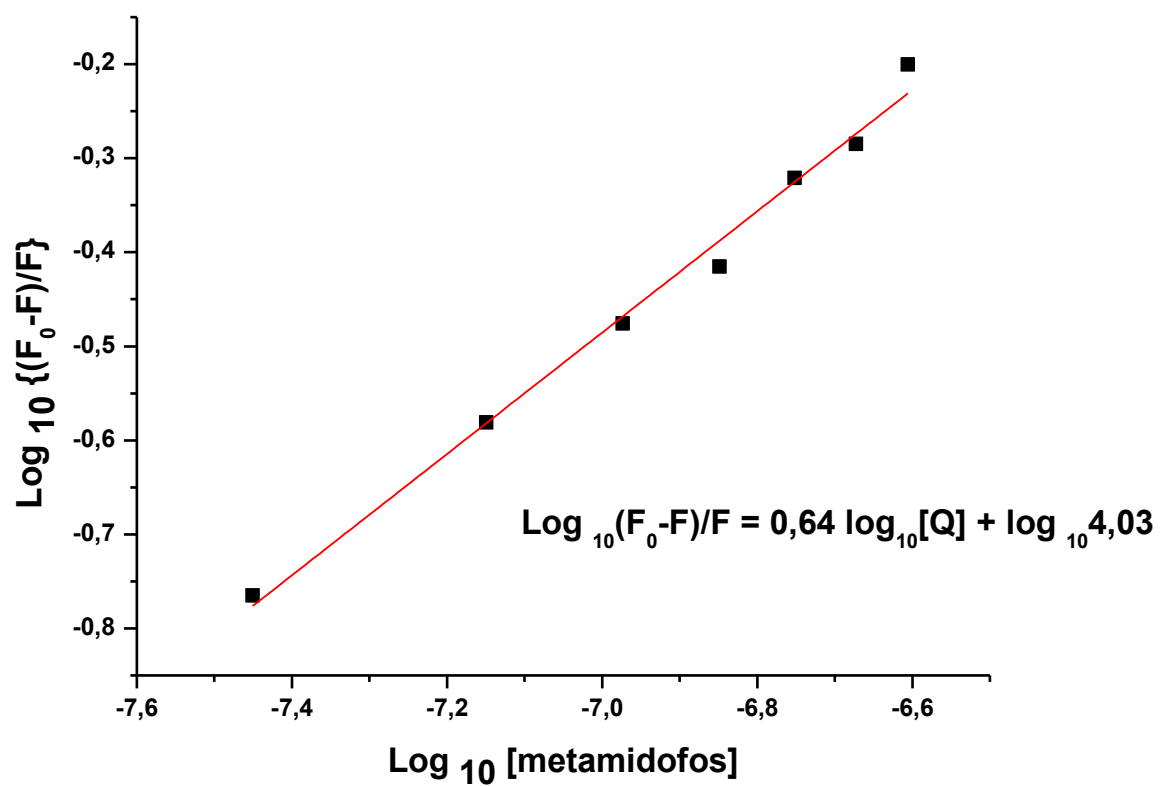

Figura 61- Gráfico do duplo-log da supressão de fluorescência do extrato por metamidofós $\left(3,5 \times 10^{-8}\right.$ à $\left.2,5 \times 10^{-7} \mathrm{~mol} \mathrm{~L}^{-1}\right)$. 


\section{4. Aplicação da tioflavina $T$}

Nos ensaios com o metomil e metamidofós não foi observada asupressão de fluorescência na fração purificada de AChE, como visto nos ensaios já mostrados. Em contrapartida, o efeito de supressão foi observado quando a fração de cérebro de rato foi utilizada, indicando diferenças entre a natureza das sondas. Para melhor compreender esse comportamento, estudos foram realizados usando a sonda tioflavina $T$, pois o uso desta sonda extrínseca permite encontrar evidências da interação (específica) entre a fração de AChE presente no extrato de cérebro de rato e seus inibidores, principalmente aqueles que não causam variação da fluorescência intrínseca das moléculas de AChE.

As medidas cinéticas da enzima, apesar de serem muito específicas, não permitem comparações com os ensaios das interações baseados em fluorescência. Os parâmetros não são os mesmos nos dois tipos de experimentos (de cinética e de supressão de fluorescência) e os princípios dos métodos empregados criam diferenças de sensibilidade da resposta a ser medida. O método de Ellman [236] para a medida da atividade/inibição da AChE utiliza a medição da absorvância do substrato específico da enzima presente no meio (acetiltiocolina) como sinal analítico. Os ensaios de interação baseados na emissão de fluorescência dos resíduos de triptofano apresentam maior sensibilidade e por isso menores concentrações de enzima e inibidores são requeridos, além de não haver necessidade da presença de outro ligante no meio como o substrato, por exemplo a acetilcolina. Ao mesmo tempo, as condições otimizadas para verificar de forma sensível o sinal espectrofotométrico para a medida da velocidade de hidrólise do substrato não é a mesma para se obter um sinal fluorescente para a medida das interações moleculares proteína-ligante.

Tendo em vista estas diferenças, realizou-se uma comparação entre a supressãoda fluorescência intrínseca da $\mathrm{AChE}(280 / 345 \mathrm{~nm})$ e o comportamento do sinal fluorescente da tioflavina T, utilizada como sonda extrínseca $(355 / 460 \mathrm{~nm})$. Estes ensaios foram realizados em dois suportes de imobilização do sensor protéico: (i) em cubeta de quartzo e (ii) em microplaca de 96 poços. Dessa forma, pôde-se avaliar também o desempenho analítico da tioflavina $\mathrm{T}$ na determinação de ligantes 
específicos da $\mathrm{AChE}$ e, ao mesmo tempo, sua aplicação como biosensor de medição em microplaca.

As condições de força iônica do tampão fosfato e o $\mathrm{pH}$ usado nos ensaios com tioflavina foram as mesmas definidas no planejamento experimental para a fluorescência intrínseca. Esta condição é necessária para permitir comparações coerentes entre os resultados obtidos com ambas as sondas fluorescentes no monitoramento dos ligantes. Na Figura 60, o espectro de soluções de tioflavina $\mathrm{T}$ em água e em tampão fosfato de sódio são mostrados, indicando os comprimentos de onda de excitação e emissão,otimizados para esta condição experimental. Verifica-se que o uso do tampão fosfato $\left(0,02 \mathrm{molL}^{-1}\right)$ potencializou o sinal fluorescente da sonda em comparação ao seu comportamento em água como já descrito na literatura [280].

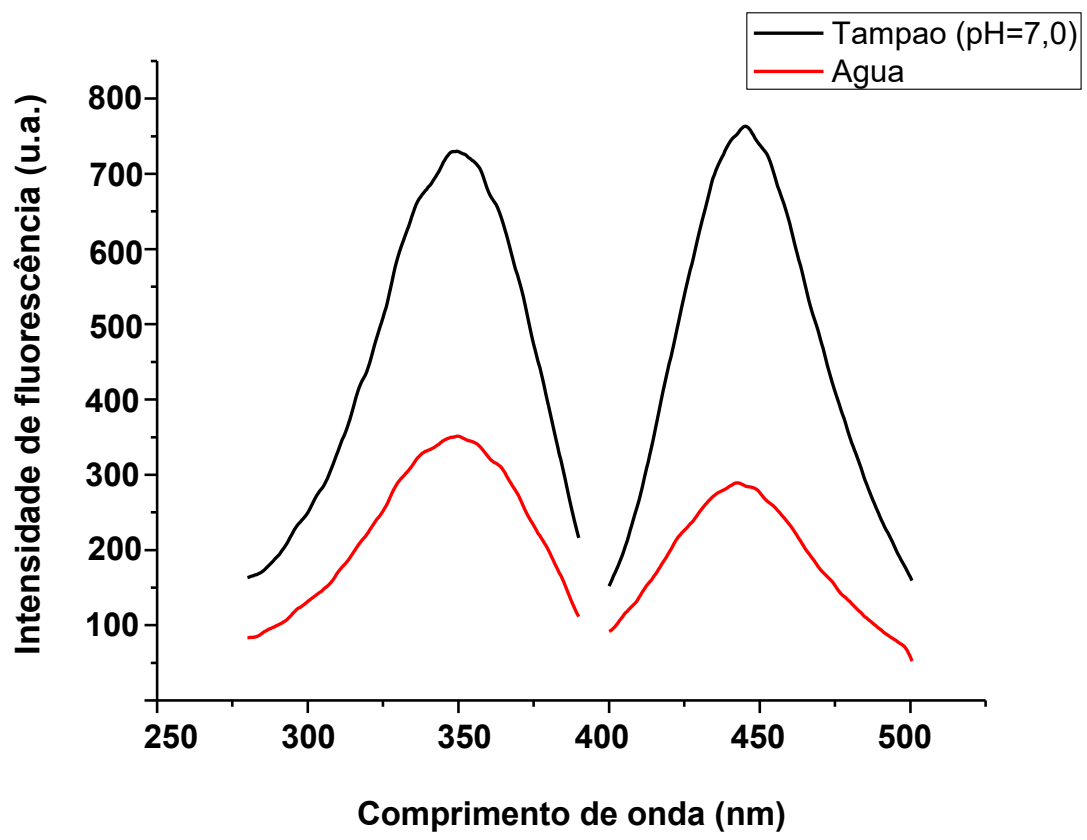

Figura 62- Espectros de excitação e emissão da solução aquosa de tioflavina T a 2,0 x 10 molL $^{-1}$ em tampão fosfato $0,02 \mathrm{~mol} \mathrm{~L}^{-1}(\mathrm{pH} \mathrm{7,1})$.

Foram realizadas medições de fluorescência em intervalos de 10 min para acompanhar a taxa de aumento do sinal da tioflavina $\mathrm{T}$ com a fração purificada $\mathrm{e}$ também com o extrato de cérebro.Observou-se que a interação da enzima purificada com a tioflavina $\mathrm{T}$ produz um pequeno aumento de sua fluorescência como 
evidenciado pelo seu espectro de emissão (Figura 61). O mesmo se observa com a interação da fração protéica de cérebro (Figura 63).

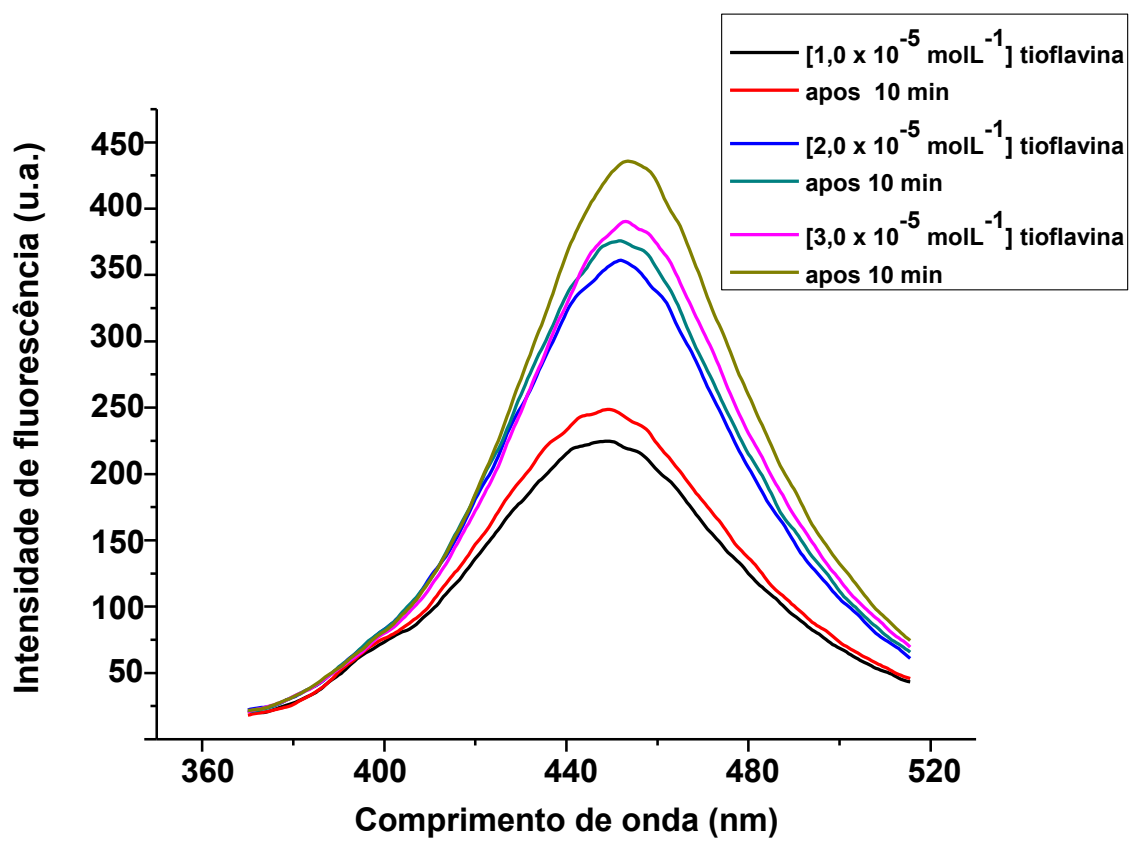

Figura 63- Espectros de emissão $\left(\lambda_{\mathrm{exc}}=.350 \mathrm{~nm}\right)$ das soluções aquosas de tioflavina $T$, nas concentrações de $1,0 \times 10^{-5}, 2,0 \times 10^{-5}$ e $3,0 \times 10^{-5} \mathrm{molL}^{-1}$, adicionadas à $6,32 \times 10^{-1} \mathrm{mg} \mathrm{mL}^{-1}$ de fração purificada de $\mathrm{AChE}$ suspensa em tampão fosfato $0,03 \mathrm{~mol} \mathrm{~L}^{-1}$ (pH 7,0). As medidas foram feitas em intervalos de $10 \mathrm{~min}$.

A concentração de $9,4 \times 10^{-3} \mathrm{mg} \mathrm{mL}^{-1}$ de AChE purificada e de $6,0 \times 10^{-1} \mathrm{mg}$ $\mathrm{mL}^{-1}$ da fração de cérebro foram suficientes para saturar este crescimento de sinal nas concentrações de tioflavina T utilizadas nos ensaios $\left(5,0 \times 10^{-5} \mathrm{~mol} \mathrm{~L}^{-1}\right.$ para a purificada e $1,1 \times 10^{-5} \mathrm{~mol} \mathrm{~L}^{-1}$ para a de cérebro de rato) provavelmente pela saturação dos sítios da AChE ocupados com tioflavina (Figura 62 e Figura 63, respectivamente). 


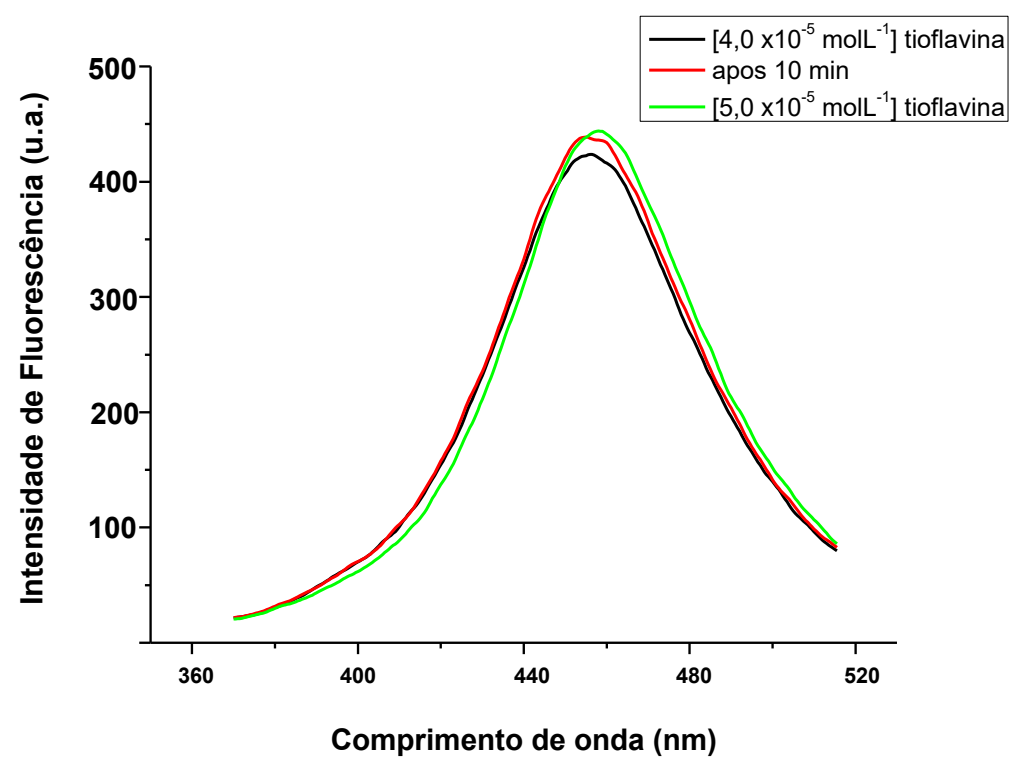

Figura 64- Espectros das soluções de tioflavina nas concentrações de 4,0 $\times 10^{-5} \mathrm{~mol} \mathrm{~L}^{-1} \mathrm{e} 5,0 \times 10^{-5} \mathrm{molL}^{-1}$, na presença de $6,32 \times 10^{-1} \mathrm{mg} \mathrm{mL}^{-1} \mathrm{de} \mathrm{AChE}$ purificada em tampão fosfato de sódio $0,03 \mathrm{molL}^{-1}(\mathrm{pH} \mathrm{7,0})$.

Realizou-se uma titulação da solução de tioflavina a $1,1 \times 10^{-5} \mathrm{~mol} \mathrm{~L}^{-1} \mathrm{com}$ adições da fração protéica de cérebro. Após um intervalo de 10 min,o sinalde fluorescência aumentou até atingir a concentração de $4,3 \mathrm{mg} \mathrm{mL}^{-1}$ de proteína total do extrato de cérebro. $\mathrm{Na}$ concentração de $6,3 \times 10^{-1} \mathrm{mg} \mathrm{mL}^{-1}$ de proteína total não foi observado mais esse incremento no sinal de fluorescência da sonda (Figura 70) Atribui-se o aumento da intensidade de sinal após a adição de AChE à pequena concentração da enzima no meio nas duas frações (purificada e de cérebro). Neste estudo se utilizou uma solução estoque de AChE purificada com 410 unidades mg${ }^{1}$ de proteína total, que por sua vez, produziu incrementos de sinal menores que as observadas na literatura [281] quando se utilizou uma solução estoque de 450 unidades nmol ${ }^{-1}$ de AChE (mais purificada). Adicionalmente, nos testes descritos em artigos publicados, a solução de tioflavina $\mathrm{T}$ é preparadaem meio micelar, com Triton x-100 em torno de 0,02\% [282], o que tende a aumentar a fluorescência. Neste trabalho o uso do surfactante foi abolido por causa das interferências espectrais causadas por suas impurezas. 


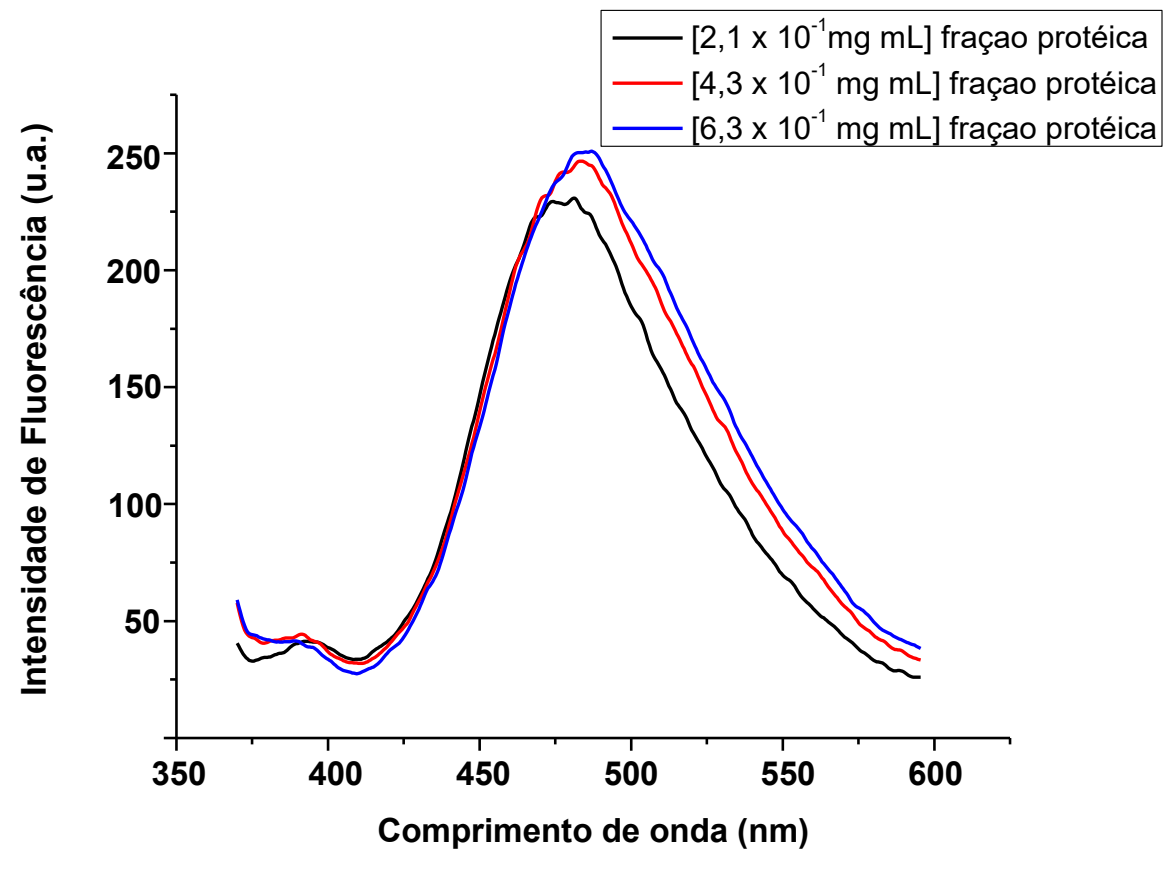

Figura 65- Espectros de solução aquosa de tioflavina $T$ a $1,1 \times 10^{-5} \mathrm{~mol}$ $L^{-1}$ titulada com a fração protéica em três concentrações de extrato: $2,1 \times 10^{-1}$; $4,3 \times 10^{-1}, 6,3 \times 10^{-1} \mathrm{mg} \mathrm{mL}^{-1}$.

Finalmente, apesar do pequeno incremento de sinal de fluorescência observado, este se torna significativo,pois foi verificada alta estabilidade da fluorescência da tioflavina $\mathrm{T}$ e das proteínas nestas condições experimentais. Este fato pode ser observado na Figura 64, que apresenta o espectro da tioflavina T após incubação com $8,0 \times 10^{-5} \mathrm{~mol} \mathrm{~L}^{-1}$ de BSA. Não se verificou efeito de aumento de sinal como mostrado anterirormente. Este resultado é corroborado pelos ensaios com AChE e tioflavina $\mathrm{T}$ nos quais se evidencia a seletividade da ligação da tioflavina $\mathrm{T}$ pelo sítio periférico da molécula desta enzima. 


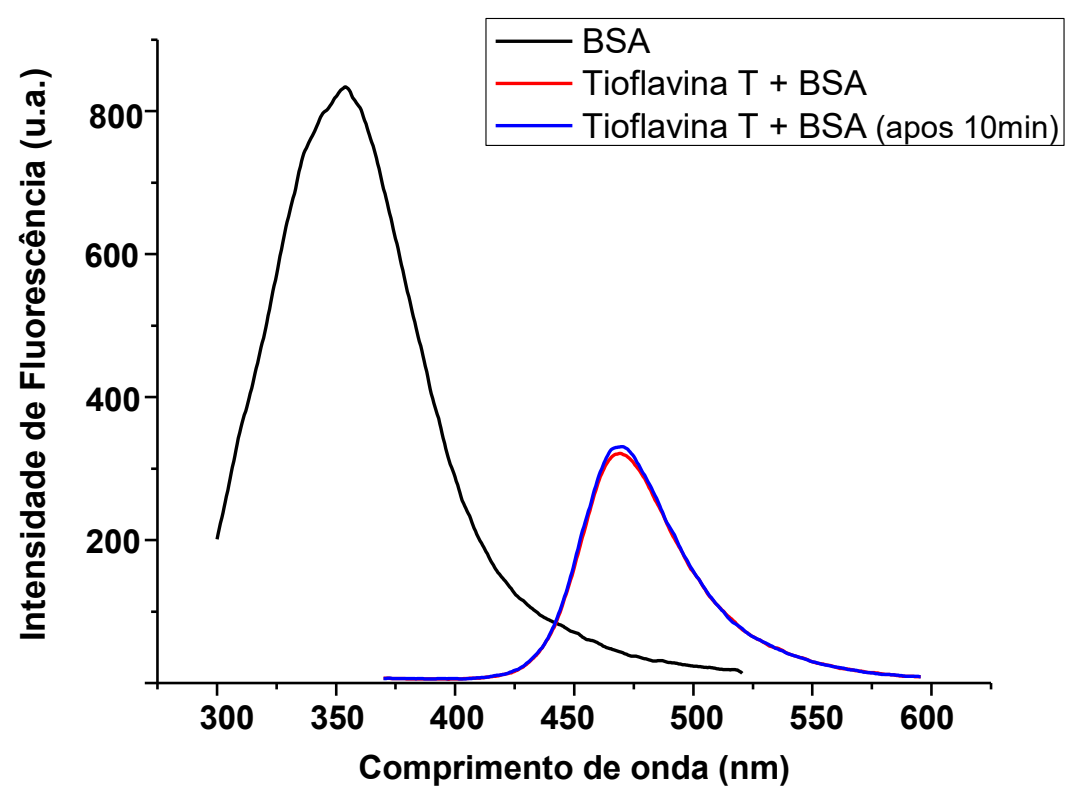

Figura 66- Espectro de emissão da BSA a $8 \times 10^{-5} \mathrm{~mol} \mathrm{~L}^{-1}$ e da tioflavina [ $2,0 \times 10^{-5} \mathrm{~mol} \mathrm{~L}^{-1}$ ] após incubação em tampão fosfato de sódio $0,03 \mathrm{~mol} \mathrm{~L}^{-1}$ (pH $7,0)$.

Ao se monitorar o sinal da AChE, apesar da significativa absorção de luz incidente da solução de tioflavina $\mathrm{T}$, responsável pelo efeito filtro interno, observase uma diminuição do sinal de fluorescência intrínseca da AChE purificada e do sinal de fluorescência das proteínas totais da subfração de cérebro. A Figura 65 mostra a diminuição do sinal de fluorescência da fração purificada após a adição de solução de tioflavina $\mathrm{T}$ a5,3 x $10^{-5} \mathrm{~mol} \mathrm{~L}^{-1}$. 


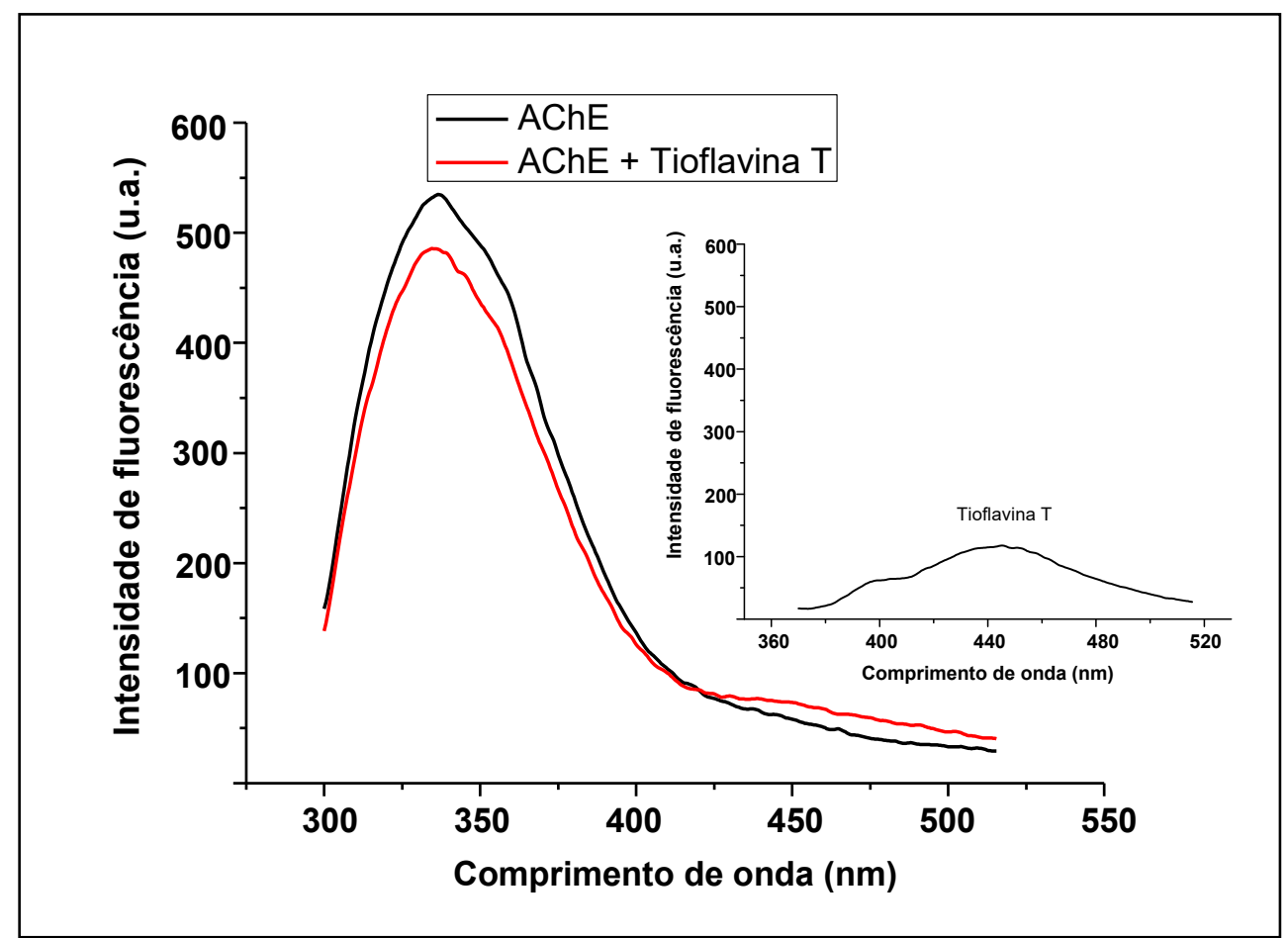

Figura 67- Espectro de emissão da AChE purificada $\left(9,4 \times 10^{-3} \mathrm{mg} \mathrm{mL}^{-1}\right)$ em tampão fosfato pH 7,0 antes e após a adição de $1,0 \times 10^{-5} \mathrm{~mol}^{-1}$ de tioflavina T. No detalhe o espectro de emissão da solução de tioflavina na mesma concentraçãoadicionada.

O mesmo efeito de supressão foi observado sobre o sinal de fluorescência da albumina como já relatado em estudos sobre a interação desta proteína com o fluoróforo [283;284]. Entretanto, no caso da albumina, esse efeito de interação não é acompanhado de mudança no sinal de fluorescência da tioflavina T. Nos estudos espectroscópicos sobre a interação albumina-tioflavina é observado um comportamento de supressão de fluorescência da albumina na presença da sonda. Isto é causado pela interação dessa molécula com um dos seus domínios (IIA da albumina humana) sem nenhum aumento de fluorescência da sonda [283]. Portanto, pode-se considerar que mesmo que a diminuição de fluorescência das protéinas (AChE ou BSA) indique a ocorrência de interações não-específicas com a tioflavina, a mudança na fluorescência desta sonda é específica para as interações com a fração de AChE.

Em incubações feitas com a fração protéica e solução de tioflavina Ta 5,3 x $10^{-5} \mathrm{molL}^{-1}$, a presença dos inibidores colinesterásicos (analitos) não causou 
alteração significativa de sua intensidade de fluorescência. A pequena concentração de AChE complexada não permite uma queda de sinal suficiente para indicar a ligação dos inibidores com o complexo AChE-tioflavina. Portanto, na abordagem utilizada nesse trabalho para monitorar a ligação dos inibidores, foram definidas condições onde a tioflavina $\mathrm{T}$ foi agente titulante (incrementos de uma solução a5,3 x $10^{-6} \mathrm{molL}^{-1}$ ) de um sistema AChE-inibidores composto pelas proteínas (extrato). Dessa forma, foi medido o sinal fluorescente total da sonda tioflavina $\mathrm{T}$ (complexada ou não) que responde proporcionalmente ao efeito dos complexos AChE-inibidores previamente formados no sistema titulado. Como experimentalmente observou-se que este efeito sobre a intensidade de fluorescência é proporcional a concentração dos inibidores (ou dos complexos AChE-inibidores formados) podemos considerar a função matemática deste comportamento fluorescente em termos analíticos para a detecção/quantificação dos inibidores de AChE.

Na Figura 66 é mostrado o espectro da solução de tioflavina T usada na titulação da fração protéica com quatro concentrações do inibidor metomil (Me), a seguir: $5,0 \times 10^{-8} ; 1,0 \times 10^{-7} ; 1,5 \times 10^{-7}$ e $2,0 \times 10^{-7} \mathrm{~mol} \mathrm{~L}^{-1}$, sob a forma AChE-Me. O perfil do espectro de emissão da sonda na presença de quatro concentrações crescentes de metomil resultou em deslocamentos espectrais da tioflavina T. Pôdese observar que as adições de tioflavina $\mathrm{T}$ resultaram em ligeira diminuição da fluorescência no comprimento de onda do pico de emissão. Esta supressão de fluorescência fica mais acentuada ao se considerar o comprimento de onda fixo de $455 \mathrm{~nm}$, por exemplo. As adições de tioflavina T não contribuiram para um aumento do sinalde fluorescência do sistema.

Apesar dos estudos sobre o comportamento espectroscópico da tioflavina T mostrar um deslocamento espectral para os comprimentos de onda maiores em função das características de polaridade do meio [280;285] fez-se aqui uma comparação em concentração de extrato fixo de modo a se eliminar a influência da mudança das condições de fluorescência em função das condições do meio (polaridade, viscosidade, etc). Este deslocamento descrito para a sonda também pode ser dependente da concentração de tioflavina T. Entretanto, a curva de tioflavina $\mathrm{T}$, na mesma faixa de concentração e na presença da mesma concentracão de extrato utilizada nos ensaios, não apresentou perfil de deslocamento de banda. 
Assim, o deslocamento observado pode ser atribuido à presença de diferentes formas da molécula de tioflavina T [285].

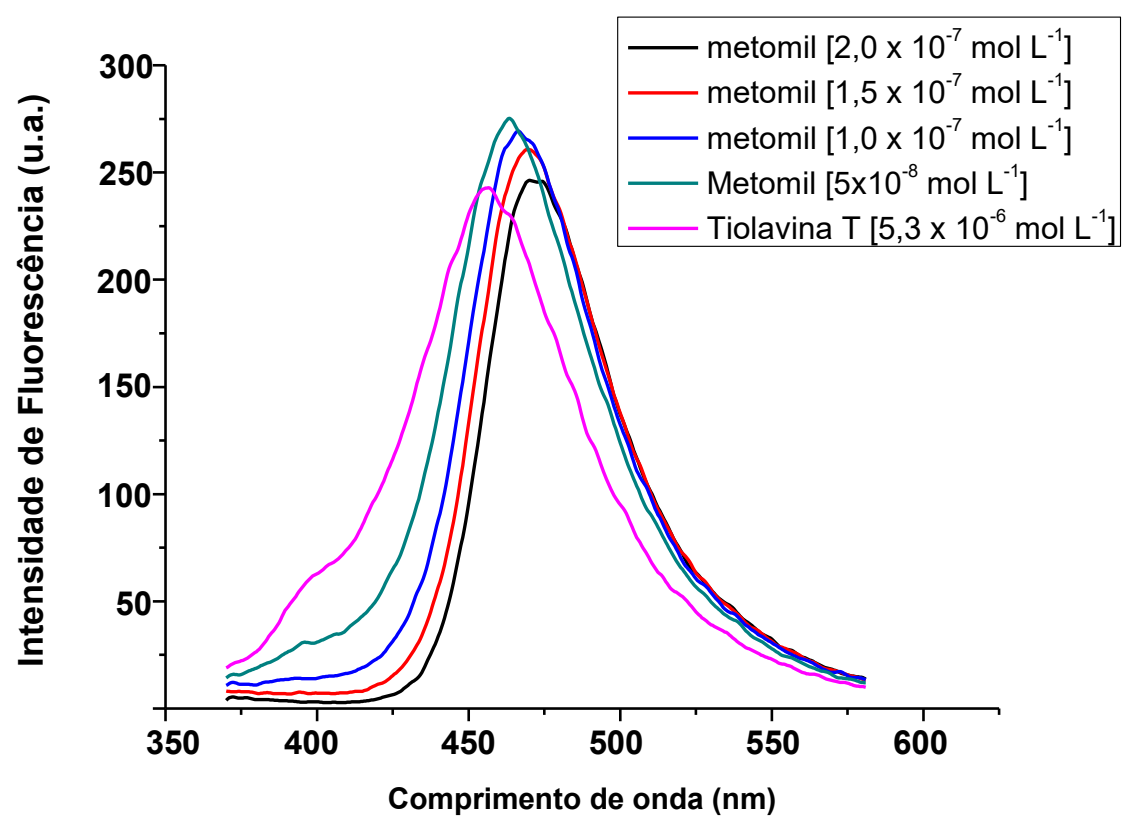

Figura 68- Espectros de emissão da solução de tioflavina a 5,3 x 10-5 mol $\mathrm{L}^{-1} \mathrm{em}$ um meio contendo a fração protéica e diferentes concentrações do inibidor metomil.

O inibidor metomil e metamidofós não provocaram variação da fluorescência intrínseca da $\mathrm{AChE}$ purificada, como visto anteriormente no item 4.3.2. Porém, através da medição da fluorescência da tioflavina T pôde-se confirmar sua interação específica com a $\mathrm{AChE}$ presente nas frações protéicas (diferentemente de comparações de comportamento de inibição enzimática cujas medidas são espectrofotométricas sob diferentes condições experimentais).

Na Figura 67 é mostrado o gráfico de Stern-Volmer apresentando o comportamento de supressão de fluorescência de quatro concentrações de tioflavina $\mathrm{T}\left(5,3 \times 10^{-6} ; 1,0 \times 10^{-6} ; 1,6 \times 10^{-5}\right.$ e $\left.2,1 \times 10^{-5} \mathrm{molL}^{-1}\right)$ na presença do inibidor anticolinesterásico metomil. Da mesma forma que a supressão de fluorescência intrínseca das proteínas, o sinal da tioflavina $\mathrm{T}$ varia proporcionalmente em função da concentração de inibidor indicando seu uso potencial para a quantificação destes ligantes à fração de $\mathrm{AChE}$. 


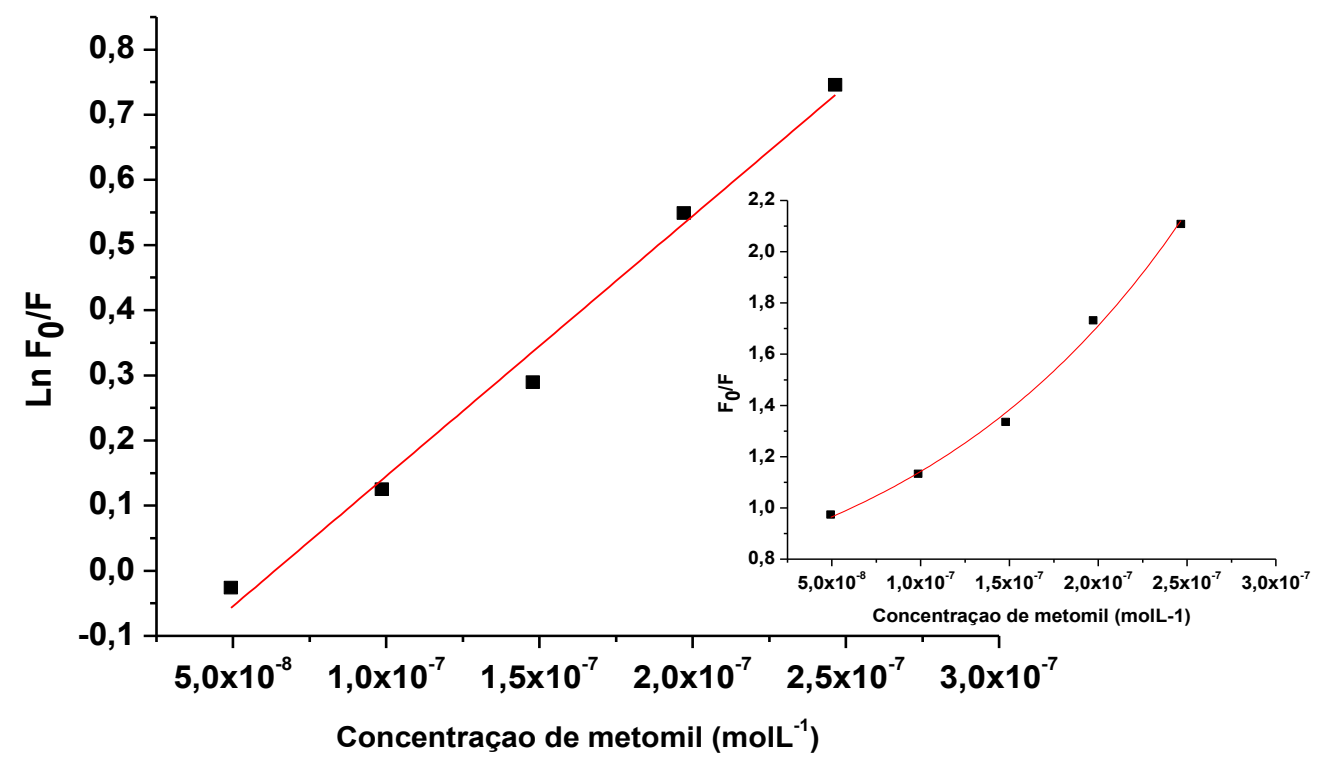

Figura 69- Curva de Stern-Volmer da supressão de fluorescência da tioflavina na presença da fração protéica de cérebro $\left[4,3 \times 10^{-1} \mathrm{mg} \mathrm{mL}\right]$ na presença de diferentes concentrações de metomil.

Para os testes em microplaca de 96 poços foram utilizadas as mesmas concentrações de tioflavina $\mathrm{T}$ e deproteínas em um volume reacional final de 0,4 mL. O equipamento empregado para as medições em placa utiliza filtros de corte, o que impossibilita a geração de espectros de emissão para caracterizar o comportamento da interação da tioflavina com as frações protéicas neste sistema de imobilização. Por isso este resultado foi expresso na forma de uma curva de supressão de fluorescência no formato Stern-Volmer.

Na Figura 68 é mostrado o comportamento da supressão de fluorescência da tioflavina $\mathrm{T}$ (sonda extrínseca) e a obtida para a fluorescência intrínseca de proteína total da fração de cérebro. A curva para tioflavina T apresenta um comportamento exponencial da queda do sinal fluorescente na presença de metomil na faixa experimental de concentração. O deslocamento do espectro de emissão da sonda é refletido, neste caso, em termos de intensidade de fluorescência em um comprimento de onda fixo $(460 \mathrm{~nm})$.

Um dos fatores para a diferença de perfil em ambas as curvas é o fato das medições da fluorescência serem feitas em comprimento de onda fixo. Por isso, 
enquanto o sinal intrínseco da sonda protéica é medido no mesmo pico de emissão, o deslocamento dos picos da tioflavina $\mathrm{T}$ (refletidos no sinal total da fluorescência na banda medida definida pelo filtro de emissão)provocam uma diminuição incremental de sinal responsável pelo perfil não linear.

É importante notar que a curva de fluorescência intrínseca se refere à resposta de fluorescência total das proteínas do extrato na presença da formação dos complexos entre (AChE-metomil) enquanto a curva da tioflavina $\mathrm{T}$ se refere à emissão da tioflavina total na presença dos complexos AChE-metomil. Portanto, as constantes de afinidade em cada caso devem ser avaliadas de formas diferentes visto que a curva de fluorescência das proteínas (intrínseca) expressa a afinidade do analito pelo sítio da AChE presentes no total de proteínas do extrato enquanto a curva de tioflavina expressa a afinidade da sonda ao complexo AChE-metomil. Além disso, a fluorescência da tioflavina $\mathrm{T}$ é bem menor que a fluorescência dos resíduos de triptofano de todas as proteínas do extrato de cérebro. Assim, a sensibilidade da curva $\mathrm{F}_{0} / \mathrm{F}$ será mais acentuada para a variação da resposta do sinal da tioflavina $T$. Por isso, as razões $F_{0} / F$ utilizando a tioflavina $T$ são mais acentuadas.

A acessibilidade dos inibidores de $\mathrm{AChE}$ às moléculas de $\mathrm{AChE}$ presentes no extrato de cérebro é muito menor do que a acessibilidade do mesmo inibidor em meio de AChE purificada. Acredita-se que em ensaios com fração mais purificadas de $\mathrm{AChE}$ as afinidades encontradas para inibidores supressores serão maiores ou similares as obtidas com a tioflavina T. Cabe ressaltar que o metomil e o metamidofós não agiram como supressores nas condições dos ensaios realizados neste trabalho. 


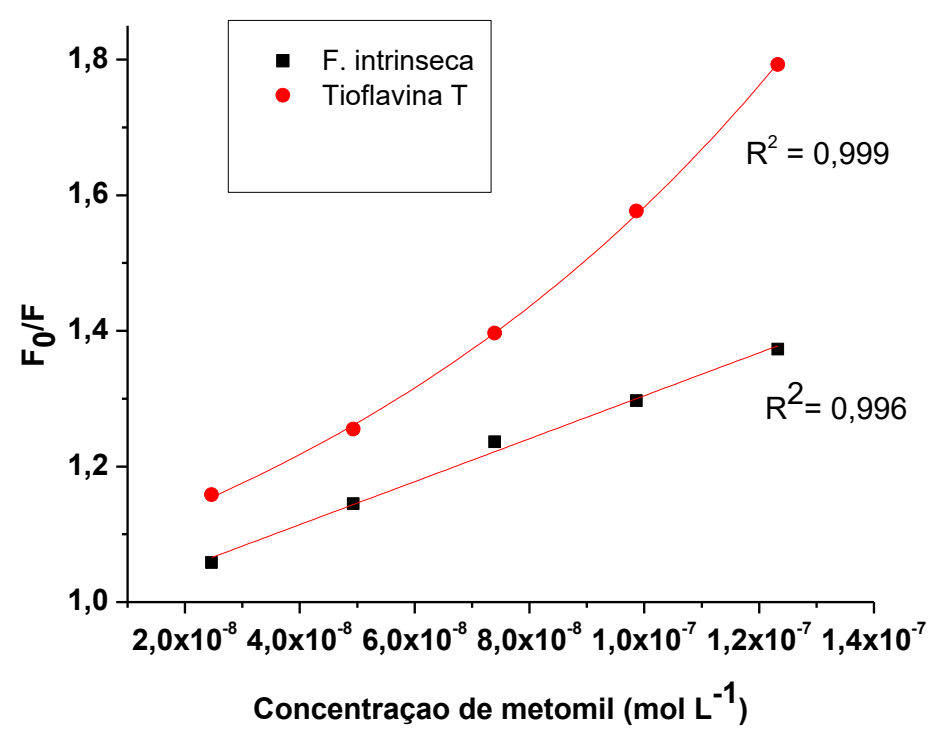

Figura 70- Curvas de Stern-Volmer para a fração protéica e para a tioflavina $T$ medidas sob as condições de $280 / 345 \mathrm{~nm}$ e $350 / 460 \mathrm{~nm}$, respectivamente em ensaios de titulação com metomil na faixa de concentração de $2,0 \times 10^{-8}$ à $1,4 \times 10^{-7} \mathrm{~mol} \mathrm{~L}^{-1}$.

Na Figura 69 é apresentada a curva de Stern-Volmer para a fluorescência da fração protéica e para a tioflavina $\mathrm{T}$ na presença e metamidofós. Observa-se o mesmo comportamento exponencial da queda do sinal fluorescente da tioflavina $\mathrm{T}$.

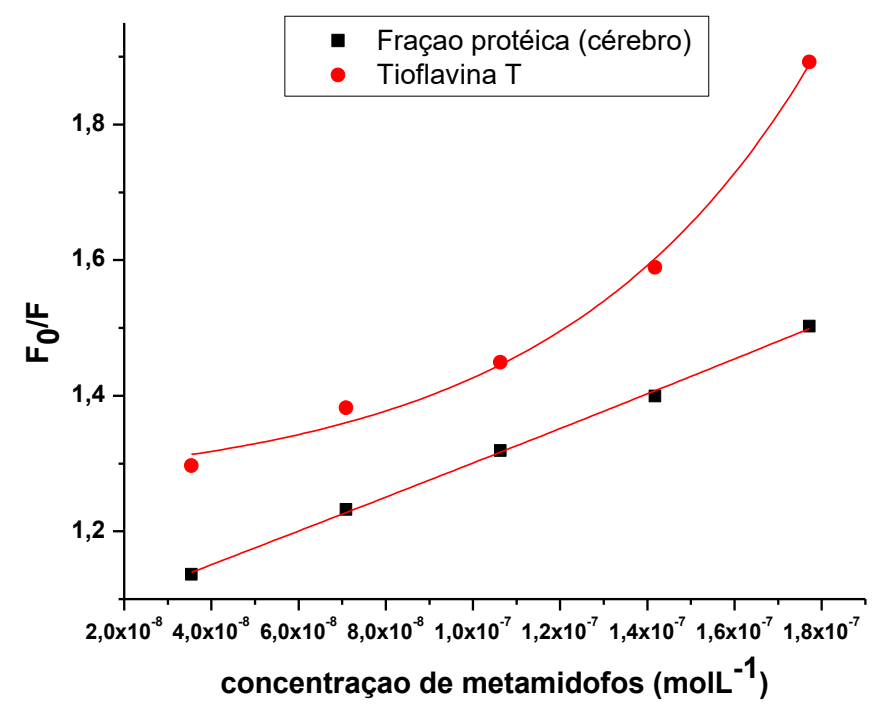


Figura 71- Curva de Stern-volmer para a fluorencência da fração protéica (cérebro) e para a tioflavina $\mathbf{T}$ em ensaios de titulação na presença de metamidofós na faixa de concentração de $2,0 \times 10^{-6}$ a $1,8 \times 10^{-7} \mathrm{molL}^{-1}$.

As linearizações dos gráficos de supressão de fluorescência frente aos agrotóxicos metomil e metamidofós podem ser utilizadas como curvas analíticas para a quantificação destes inibidores. Além disso, o uso do sistema de imobilização da fração protéica em microplaca e a detecção da fluorescência da tioflavina $\mathrm{T}$ atenderam satisfatoriamente os objetivos de aplicação de sondas extrínsecas na detecção e/ou quantificação de ligantes específicos de proteínas. O suporte de microplacas não comprometeu as afinidades dos componentes do meio reacional permitindo a formação dos complexos e garantindo a sensibilidade adequada às determinações dos testes como os obtidos em cubetas de quartzo.

A metodologia também permitiu a comparação, por meio de ensaios por fluorescência, das interações específicas da AChE (presente no extrato) e seus ligantes específicos metomil e metamidofós. Estes analitos não apresentaram variação da fluorescência intrínseca da $\mathrm{AChE} \mathrm{purificada} \mathrm{em} \mathrm{testes} \mathrm{anteriores} \mathrm{(item}$ 4.3.2) e, por isso não foi possível confirmar os resultados obtidos nos ensaios de supressão de fluorescência com a fração de cérebro como uma interação específica da fração da enzima AChE presente nesta preparação. A partir dos resultados da fluorescência da sonda extrínseca pôde-se confirmar a especificidade das respostas de diminuição de fluorescência das proteínas do sensor protéico pelos dois analitos estudados (metomil e metamidofós).

Este estudo inicial sobre o emprego da tioflavina $\mathrm{T}$ merece uma etapa de otimização para se alcançar melhor sensibilidade das curvas de supressão e de aumento de fluorescência desta sonda. Seu uso torna os métodos por fluorescência mais versáteis com o emprego de diferentes equipamentos de medição e suportes de imobilização. O exemplo do uso de um biosensor imobilizado em microplaca de 96 poços pode permitir medições mais rápidas com sensibilidade e seletividade adequadas, visto a especificidade desta sonda.

Além disso, mais uma vez, verificou-se o desempenho satisfatório do emprego da fração protéica obtida de cérebro de ratos para determinações analíticas utilizando sondas proteíno-específicas como a tioflavina T. Apesar das curvas 
obtidas dos ensaios com os inibidores terem apresentado sensibilidade adequada para medições em diferentes amostras, as otimizações experimentais e o estudos dos interferentes são fundamentais para esta aplicação. Estudos sobre a seletividade desta sonda também merecem atenção visto que as nítidas diferenças espectrais obtidas em ensaios com os inibidores podem permitir determinações multi-residuais específicas com a ajuda de ferramentas da estatística multivariada.

Embora esta sonda tenha especificidade à AChE, uma das dificuldades analíticas nos estudos com material biológico é a manutenção da sensibilidade e da especificidade comparado à testes com frações altamente purificadas de proteínas e outros componentes celulares. Isso acontece em estudos sobre cinética enzimática e em simulações da ação de drogas em meio biologico. A abordagem analítica para aplicações com a tioflavina $\mathrm{T}$ para preparações biológicas como realizado neste trabalho também permite o uso desta sonda para estes outros tipos de ensaio biológicos com a maior sensibilidade que a fluorescência oferece. 


\section{5. Validação dos métodos}

Para a aplicação do princípio de extinção estática de fluorescência como método de determinação dos analitos em questão, a validação foi realizada em diferentes amostras. Osseguintes parâmetros de desempenho do método proposto foram obtidos: reprodutibilidade, repetitividade, limite de detecção (LD), limite de quantificação (LQ), faixa de resposta lineare taxa de recuperação dos analitos nas amostras de água, urina e solo.

As curvas analíticas para cada composto foram realizadas sob as condições definidas nos planejamentos experimentais. As curvas foram contruídas a partir de quatro titulações independentes da fração protéica em tampão fosfato de sódio. Para eliminar interferências, após a contrução das curvas, cada uma das frações já tituladas, após alcançar seu ponto de saturação, foi utilizada como sensor saturado para as medidas de fluorescência com as amostras. Em seguida adicionou-se uma alíquota das amostras fortificadas no sistema já titulado e mediu-se o sinal de fluorescência após 1 min.

As curvas analíticas foram construídas a partir das medidas de titulação e convertidas para o modelo das curvas de supressão (Stern-Volmer). O conjunto de medidas teve caráter homocedástico em todos os casos (segundo teste de Levene) no qual o modelo de regressão linear foi bem ajustado aos dados. Nas Figuras 70 a 74 estão apresentadas as curvas analíticas para Gal, atropina, metomil, metamidofós e metil paration, respectivamente. 


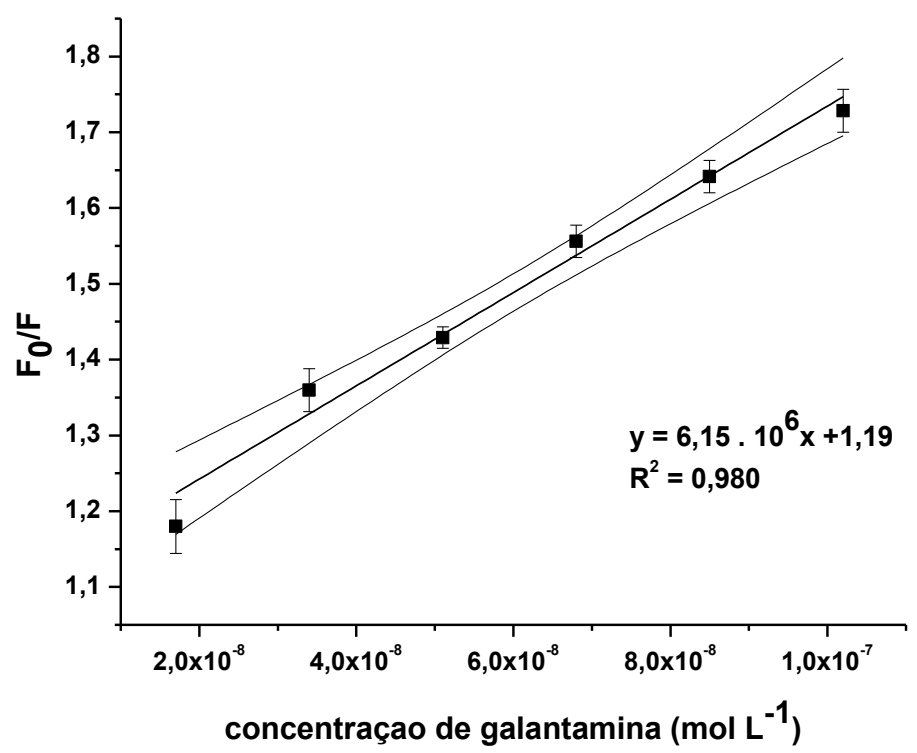

Figura 72- Curva analítica da galantamina na faixa deconcentração de 2,0x10-8 $\mathrm{mol} \mathrm{L}^{-1}$ à $1,0 \times 10^{-7} \mathrm{~mol} \mathrm{~L}^{-1}$, com o valor médio de $\mathrm{F}_{0} / \mathrm{Fe}$ desvio-padrão.

Média de quatro titulações independentes.

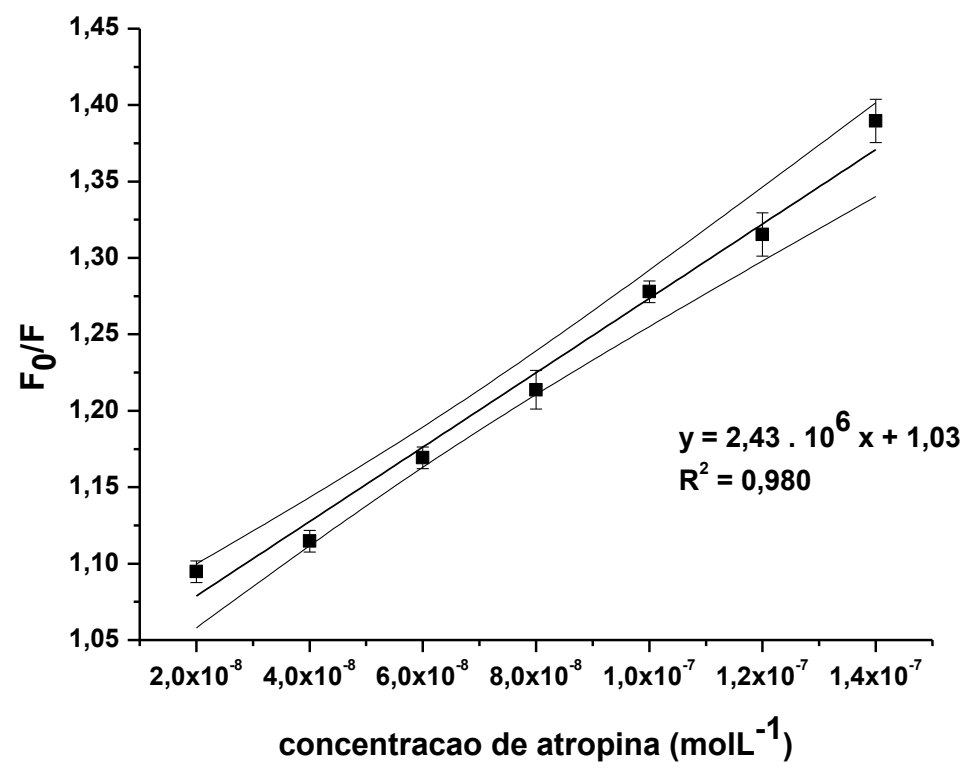

Figura 73- Curva analítica da atropina na faixa deconcentração de $2,0 \mathrm{x}$ $10^{-8}$ mol $\mathrm{L}^{-1}$ à $1,4 \times 10^{-7} \mathrm{~mol} \mathrm{~L}^{-1}, \mathrm{com}$ o valor médio de $\mathrm{F}$ / $/ \mathrm{Fe}$ desvio-padrão. Médiade quatro titulações independentes. 


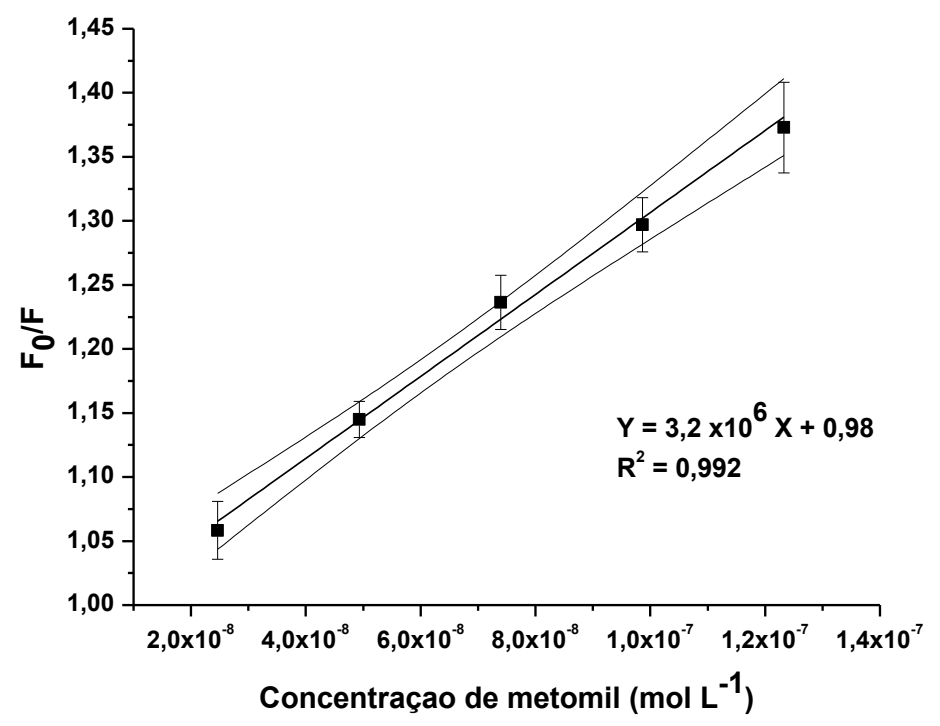

Figura 74- Curva analítica do metomil na concentração de 2,0 x $10^{-8} \mathrm{~mol}$ $\mathrm{L}^{-1}$ à $1,4 \times 10^{-7} \mathrm{~mol} \mathrm{~L}^{-1}$, com o valor médio de $\mathrm{F}_{0} / \mathrm{Fe}$ desvio-padrão. Média de quatro titulações independentes.

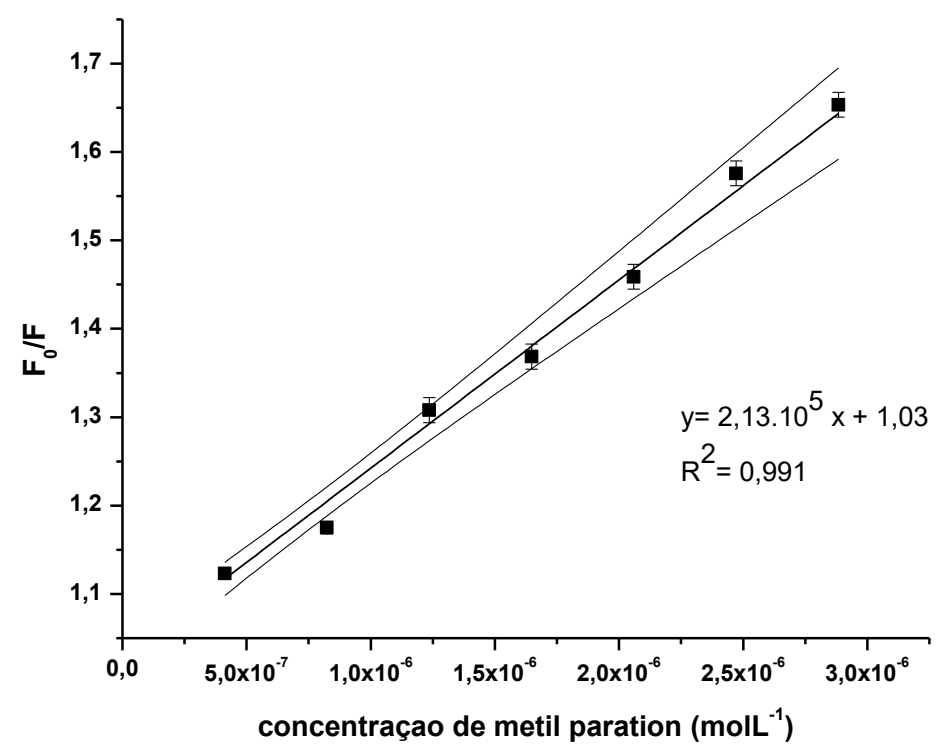

Figura 75- Curva analítica de metamidofós na faixa de concentração de $5,0 \times 10^{-7} \mathrm{~mol} \mathrm{~L}^{-1}$ à $3,0 \times 10^{-6} \mathrm{~mol} \mathrm{~L}^{-1}$, com o valor médio de $\mathrm{F}$ o/Fe desvio-padrão. Média de quatro titulações independentes. 


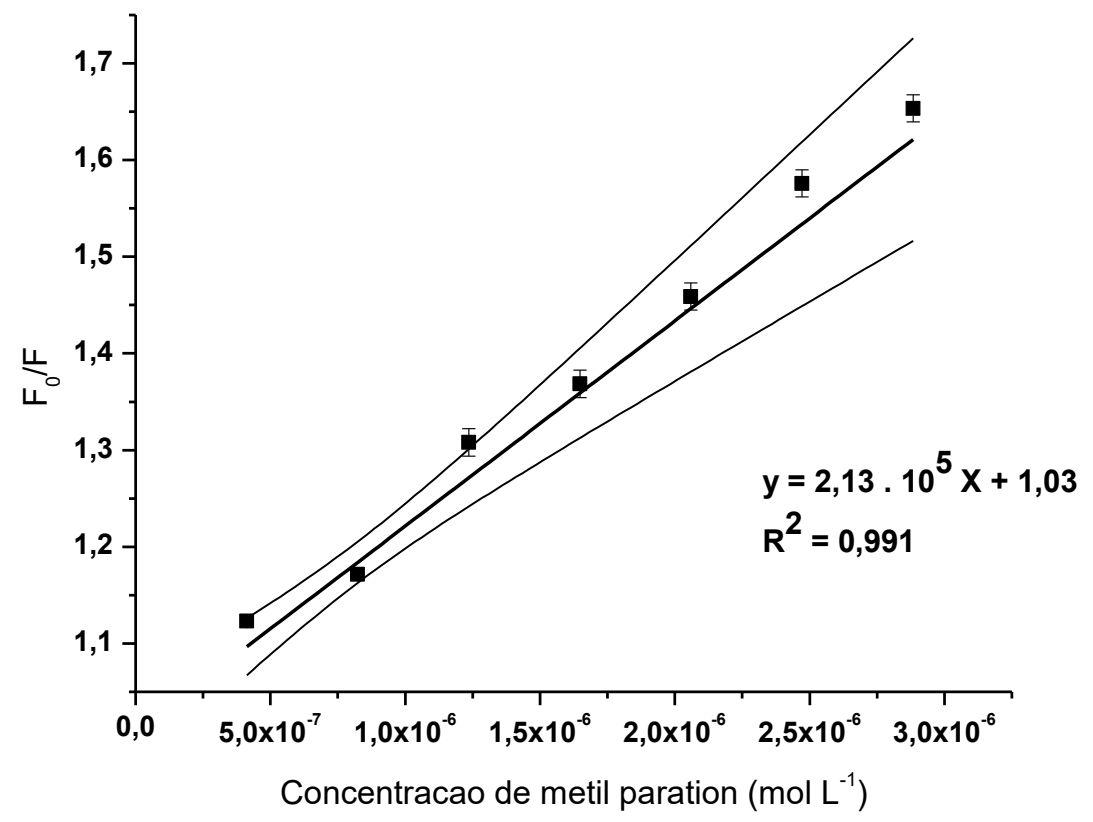

Figura 76- Curva analítica de metil paration na faixa de concentração de $5,0 \times 10^{-7} \mathrm{~mol} \mathrm{~L}^{-1}$ à $3,0 \times 10^{-6} \mathrm{~mol} \mathrm{~L}^{-1}, \mathrm{com}$ o valor médio de $\mathrm{F}$ o/Fe desvio-padrão. Médiade quatro titulações independentes.

A Tabela 17 apresenta a análise de comparação de variâncias (ANOVA) para os dois grupos de medições em equipamentos diferentes. A média de sete determinações de Gal foi de 5,9 x $10^{-8} \mathrm{~mol} \mathrm{~L}^{-1}$ e $6,0 \times 10^{-8} \mathrm{~mol} \mathrm{~L}^{-1}$, respectivamente para os dois equipamentos.

Tabela 17 - Resultado de ANOVA para dois conjuntos de determinações de Gal pelo método proposto em diferentes equipamentos.

\begin{tabular}{lccccrr}
\hline \multicolumn{1}{r}{$\begin{array}{l}\text { Fonte da } \\
\text { variação }\end{array}$} & $S Q$ & $G l$ & $M Q$ & $F$ & valor- $P$ & F crítico \\
\hline $\begin{array}{l}\text { Entre grupos } \\
\text { Dentro dos } \\
\text { grupos }\end{array}$ & $2,6 \times 10^{-18}$ & 1 & $2,6 \times 10^{-18}$ & 0,66 & 0,43 & 4,75 \\
& $4,7 \times 10^{-17}$ & 12 & $3,9 \times 10^{-18}$ & & & \\
Total & $4,9 \times 10^{-17}$ & 13 & & & & \\
\hline
\end{tabular}


A Tabela 18 apresenta a ANOVA para os dois conjuntos de determinações da atropina. As respectivas médias foram de $6,0 \times 10^{-8} \mathrm{~mol} \mathrm{~L}^{-1}$ e $5,97 \times 10^{-8} \mathrm{~mol} \mathrm{~L}$ 1 .

Tabela 18 -Resultado de ANOVA para dois conjuntos de determinações de atropina pelo método proposto em diferentes equipamentos.

\begin{tabular}{lccccrr}
\hline \multicolumn{1}{c}{$\begin{array}{l}\text { Fonte da } \\
\text { variação }\end{array}$} & $S Q$ & $G l$ & $M Q$ & $F$ & valor- $P$ & F crítico \\
\hline $\begin{array}{l}\text { Entre grupos } \\
\begin{array}{l}\text { Dentro dos } \\
\text { grupos }\end{array}\end{array}$ & $7,1 \times 10^{-20}$ & 1 & $7,1 \times 10^{-20}$ & 0,03 & 0,86 & 4,75 \\
Total & $2,8 \times 10^{-17}$ & 12 & $2,4 \times 10^{-18}$ & & & \\
\hline
\end{tabular}

Para as determinações de metomil a média foi de $5,9 \times 10^{-8} \mathrm{molL}^{-1}$ para ambos os equipamentos. A Tabela 19 apresenta a análise de variância para as duas determinações.

Tabela 19 - Resultado de ANOVA para dois conjuntos de determinações de metomil pelo método proposto em diferentes equipamentos.

\begin{tabular}{lccccrr}
\hline \multicolumn{1}{r}{$\begin{array}{l}\text { Fonte da } \\
\text { variação }\end{array}$} & SQ & Gl & MQ & F & valor-P & F crítico \\
\hline $\begin{array}{l}\text { Entre grupos } \\
\begin{array}{l}\text { Dentro dos } \\
\text { grupos }\end{array}\end{array}$ & $2,7 \times 1^{-19}$ & 1 & $2,9 \times 10^{-19}$ & 0,07 & 0,79 & 4,74 \\
Total & $4,9 \times 10^{-17}$ & 12 & $4,0 \times 10^{-18}$ & & & \\
\hline
\end{tabular}

Para a determinaçãode metil paration, a média foi de $5,9 \times 10^{-8} \mathrm{~mol} \mathrm{~L}^{-1}$ para ambos os métodos. Na Tabela 20 é apresentado o resultado da análise de variância para os dois conjuntos de medidas.

Tabela 20- Resultado de ANOVA para dois conjuntos de determinações de metil paration pelo método proposto em diferentes equipamentos. 


\begin{tabular}{lccccrr}
\hline \multicolumn{1}{c}{$\begin{array}{l}\text { Fonte da } \\
\text { variação }\end{array}$} & $S Q$ & $g l$ & $M Q$ & $F$ & valor- $P$ & F crítico \\
\hline $\begin{array}{l}\text { Entre grupos } \\
\begin{array}{l}\text { Dentro dos } \\
\text { grupos }\end{array}\end{array}$ & $2,6 \times 10^{-16}$ & 1 & $2,6 \times 10^{-16}$ & 0,61 & 0,45 & 4,75 \\
& $5,0 \times 10^{-15}$ & 12 & $4,2 \times 10^{-16}$ & & & \\
Total & $5,3 \times 10^{-15}$ & 13 & & & & \\
\hline
\end{tabular}

Os valores de reprodutibilidade foram expressos em termos de \% RSD. As determinaçõesde $\mathrm{Gal}$ foram as que apresentaram maior percentual de variação $(3,2 \%)$ seguida das referentes ao metil paration $(1,7 \%)$. Os demais analitos não apresentaram variações importantes nas determinações realizadas em diferentes equipamentos com medições precisas dos sistemas forificados (Tabela 21).

Tabela 21 - Cálculo da reprodutibilidade do método proposto para os 5 analitos estudados.

\begin{tabular}{ccccc}
\hline Analitos & $\mathbf{S}^{\mathbf{2}}$ & $\mathbf{S}^{\mathbf{2}} \mathbf{R}$ & $\mathbf{S}_{\mathbf{R}}$ & $\begin{array}{c}\mathbf{\%} \\
\text { variação }\end{array}$ \\
\hline Gal & $3,9 \times 10^{-18}$ & $3,7 \times 10^{-18}$ & $1,9 \times 10^{-09}$ & 3,20 \\
\hline Atropina & $2,4 \times 10^{-18}$ & $2,0 \times 10^{-18}$ & $1,4 \times 10^{-09}$ & 0,02 \\
\hline Metomil & $4,0 \times 10^{-18}$ & $3,5 \times 10^{-18}$ & $1,9 \times 10^{-09}$ & 0,03 \\
\hline Metamidofós & $4,4 \times 10^{-18}$ & $4,1 \times 10^{-18}$ & $2,03 \times 10^{-09}$ & 0,03 \\
\hline Metil paration & $4,2 \times 10^{-16}$ & $3,9 \times 10^{-16}$ & $2,0 \times 10^{-08}$ & 1,65 \\
\hline
\end{tabular}

Na Tabela 22 são apresentados uma síntese dos parâmeros de mérito para o método proposto para os cinco analitos estudados. Em todas as determinações os valores de LD e de LQ foram satisfatórios para a aplicação do método em amostras ambientais e clínicas.

Tabela 22 - Síntese com os parâmetros de desempenho das curvas analíticas dos analitos estudados. 


\begin{tabular}{|c|c|c|c|c|}
\hline Analito & $\begin{array}{c}\text { Repetitiv. } \\
\text { (\%) }\end{array}$ & $\begin{array}{c}\text { LD } \\
\left(\mathrm{molL}^{-1}\right) \\
\left.(\mu \mathrm{g} \mathrm{L})^{-1}\right)\end{array}$ & $\begin{array}{c}\text { Limite de } \\
\text { quantificação } \\
\left(\mathrm{molL}^{-1}\right) \\
\left(\mu \mathrm{g} \mathrm{L}^{-1}\right)\end{array}$ & $\begin{array}{c}\text { Reprodutib. } \\
(\%)\end{array}$ \\
\hline Galantamina & 3,91 & $\begin{array}{l}1,3 \times 10^{-9} \\
3,7 \times 10^{-1}\end{array}$ & $\begin{array}{c}2,1 \times 10^{-8} \\
6,03\end{array}$ & 3,20 \\
\hline Atropina & 2,5 & $\begin{array}{l}9,7 \times 10^{-10} \\
2,8 \times 10^{-1}\end{array}$ & $\begin{array}{c}2,4 \times 10^{-8} \\
6,9\end{array}$ & 0,02 \\
\hline Metomil & 3,95 & $\begin{array}{r}9,5 \times 10^{-10} \\
1,54 \times 10^{-1}\end{array}$ & $\begin{array}{c}2,2 \times 10^{-8} \\
3,5\end{array}$ & 0,03 \\
\hline Metamidofós & 3,78 & $\begin{array}{l}1,5 \times 10^{-9} \\
2,1 \times 10^{-1}\end{array}$ & $\begin{array}{c}3,8 \times 10^{-8} \\
5,4\end{array}$ & 0,03 \\
\hline Metil paration & 1,49 & $\begin{array}{l}9,7 \times 10^{-10} \\
2,5 \times 10^{-1}\end{array}$ & $\begin{array}{c}1,80 \times 10^{-7} \\
4,7 \times 10^{1}\end{array}$ & 1,65 \\
\hline
\end{tabular}

Atualmente se observa-se um aumento de métodos analíticos baseados em fluorescência aplicados à estudos de cinética enzimática e na construção de biosensores.Métodos cinéticos da $\mathrm{AChE}$ aplicados na determinação de inibidores (pesticidas) têm alcançado LD igual a $1,0 \times 10^{-11} \mathrm{~mol} \mathrm{~L}^{-1}$ para o paration (paraoxon) e $2,9 \times 10^{-9} \mathrm{~mol} \mathrm{~L}^{-1}$ para o carbaril (carbamato) empregando nanocristais fluorescentes de CdTe [286]. Outros métodos cinéticos baseados em sondas fluorescentes têm desenvolvido ensaios com tacrina (inibidor usado na tratamento de Alzheimer)em concentrações de até $2,9 \times 10^{-8} \mathrm{~mol} \mathrm{~L}^{-1}$ da droga. [287]. Para as medidas eletroquímicas da atividade da $\mathrm{AChE}$ as detecções alcançam limites de 10${ }^{8} \mathrm{~g} \mathrm{~L}^{-1}\left(7,1 \times 10^{-11} \mathrm{~mol} \mathrm{~L}^{-1}\right)$ para o metamidofós [288]. A principal diferença destes métodos para o método proposto neste trabalho é a natureza da medida fluorescente ques está baseada nas interações entre a sonda-analito e não na atividade da enzima. Apesar da medida cinética da AChE por fluorescência apresentar maior sensibilidade quando comparada aos métodos que utilizam a reação de Ellman (LQ $=3,4 \times 10^{-11} \mathrm{~mol} \mathrm{~L}^{-1} \mathrm{em}$ amostras de água) [250], esta detecção cinética ainda não permite seletividade ao efeito dos inibidores.

As determinações de Gal pelo método de extinção de fluorescência da fração de proteínas do extrato de tecido cerebral de rato apresentou desempenho satisfatório para atender as demandas analíticas de diferentes tipos de amostras (LD $\left.=1,3 \times 10^{-9} \mathrm{~mol} \mathrm{~L}^{-1} \mathrm{e} \mathrm{LQ}=2,1 \times 10^{-8} \mathrm{~mol} \mathrm{~L}^{-1}\right)$. A título de comparação, o método para determinar Gal pela sua fluorescência intrínseca (utilização de um meio micelar (SDS) para compensar a fraca fluorescência deste analito) em amostras de 
água, com prévia separação cromatográfica, alcançaram valor de LQ de $24 \mathrm{ng} \mathrm{mL}$ ${ }^{1}\left(8,3 \times 10^{-8} \mathrm{~mol} \mathrm{~L}^{-1}\right)[156]$. No caso dos métodos enzimáticos que utilizam a $\mathrm{AChE}$ imobilizada, as determinações espectrofotométricas atingiram limites de detecção de 5 x $10^{-7} \mathrm{~mol} \mathrm{~L}^{-1}$ de Gal [160] em sistemas de injeção em fluxo. Ao mesmo tempo em que as determinações pelo método de supressão de fluorescência alcançaram maior sensibilidade que o obtido para o método fotométrico, este também apresentou melhor desempenho quando comparado às determinações por fluorescência intrínseca do próprio analito.

Os valores de LD e LQ para atropina $\left(9,7 \times 10^{-10} \mathrm{~mol} \mathrm{~L}^{-1}\right.$ e $2,4 \times 10^{-8} \mathrm{~mol} \mathrm{~L}$ 1 , respectivamente) mostram-se adequados visto que outros sensores, como os eletroquimioluminescentes, apresentaram um valor de LQ de $1 \times 10^{-7} \mathrm{molL}^{-1}$ para atropina em determinações em amostras de urina [168]. Pela importância clínica e forense das determinações de atropina em diferentes amostras complexas que quantifiquem seletivamente sua fração ativa, o método proposto apresenta um desempenho satisfatório quando comparado aos métodos de varredura utilizados antes da confirmação por CG-MS. Utilizando técnicas de imunoensaios (RIA) é possível quantificar amostras em torno de $1 \mathrm{ng} \mathrm{mL}^{-1}$ de atropina, enquanto que em ensaios com radiorreceptores (RRA) os níveis plasmáticos do isômero ativo 1-

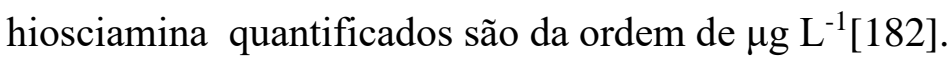

O método para o pesticida metomil $\left(\mathrm{LD}=9,5 \times 10^{-10} \mathrm{~mol} \mathrm{~L}^{-1} \mathrm{e} \mathrm{LQ}=2,2 \mathrm{x}\right.$ $10^{-8} \mathrm{~mol} \mathrm{~L}^{-1}$ ) apresentou um bom desempenho quando comparado à outros métodos. Em sistemas cromatográficos acoplados à espectrometria de massas (triplo quadrupolo) foi obtido um valor de LD para o metomil na faixa de $0,01 \mu \mathrm{gL}^{-1}$ a $3,494 \mu \mathrm{g} \mathrm{L} \mathrm{L}^{-1} \mathrm{em}$ amostras de urina[105]. A determinação de metomil em amostras de cenoura e tomate utilizando o biossensor baseado na enzima LAC apresentou valor de LQ igual a 7,8x $10^{-7} \mathrm{~mol} \mathrm{~L}^{-1}$ [115]. Já os métodos de determinação de carbamatos por fluorescência com aplicação de sistemas poliméricos (ciclodextrina e a quitosana) alcançam valores de $\mathrm{LD}$ da ordem de $0,1 \mu \mathrm{g} \mathrm{mL}^{-1}$ e $1 \mu \mathrm{g} \mathrm{mL} \mathrm{m}^{-1}$ [112]. Um método baseado na inibição da AChE em micro-reator, gerando um aumento em sua constante de inibição, alcançou um valor de LD de $1.0 \mu \mathrm{mol} \mathrm{\textrm {L } ^ { - 1 }}$ para o metomil [125]. Portanto, os métodos baseados na afinidade do metomil (e demais compostos do grupo dos carbamatos) por enzimas (LAC e AChE) têm mostrado desempenho com menor sensibilidade do que o proposto por fluorescência 
(supressão). Por outro lado, os métodos que procuram maximizar o sinal fluorescente destes compostos não apresentam mesmo desempenho.

Para a detecção de metamidofós foi desenvolvido um sensor amperométrico baseado na imobilização da AChE que permitiu a menor concentração detectável de $9,93 \times 10^{-9} \mathrm{~mol} \mathrm{~L}^{-1}$ [143]. Um método por fluorescência, baseado na fotodegradação do metamidofós e sua posterior reação com uma sonda fluorescente alcançou um valor de $\mathrm{LD}$ de $1,7 \mathrm{ng} \mathrm{mL}^{-1}\left(1,2 \times 10^{-11} \mathrm{~mol} \mathrm{~L}^{-1)}\right.$ [145]. Para a determinação dos pesticidas acefato e metamidofós utilizando cromatografia líquida com pós-coluna de fotoderivatização para detecção por fluorescência foram obtidos valores de LD de 4 à $12 \mathrm{ng} \mathrm{mL}^{-1}$ [147]. Utlizando-se a detecção por espectrometria de massa, em amostras de mel e pólen, foram encontrados valores de LQ de 40,0 $\mathrm{ng} \mathrm{g}^{-1}$ para esse analito [146].

\subsection{1. \\ Estudo de seletividade}

O sensor baseado em um biocomponente multiprotéico pode sofrer interferência de um grande número de substâncias já que estas podem interagir com outros sítios presentes no sensor. Por exemplo, componentes presentes nas matrizes clínicas e ambientais contém compostos que podem induzir efeitos significativos de extinção de fluorescência das proteínas. Em eventos de extinção de fluorescência é possível subtrair o efeito de supressão não específico (não causada pelo analito) definindo uma condição inicial de fluorescência $\left(\mathrm{F}_{0}\right)$ somente após a adição da amostra ao sistema com o sensor. Desta forma tenta-se aumentar a seletividade da abordagem. Em sensores multiprotéicos, como o apresentado nesse trabalho, a resposta de fluorescência à ocorrência de interações não são devidas unicamente à formação de complexo com a $\mathrm{AChE}$ ou com seus receptores específicos. Neste caso, deve-se considerar que a supressão observada seja a soma das interações, preferencialmente em sítios específicos de moléculas- alvo, mas que pode envolver outro tipo de interação ou ligações em sítios não específicos inclusive com outras proteínas.

A extinção de fluorescência causada pelo analito e pelos interferentes podem ser discriminados pela diferença da supressão total de fluorescência causada pela amostra e a fluorescência medida utilizando a fração protéica saturada 
(saturação com o respectivo analito). A ausência de concentrações detectáveis do analito é verificada quando não existe nenhuma diferença entre a medição da supressão de fluorescência total (fração protéica livre) e a saturada com o analito. Como a contribuição de possíveis interferentes é descontada, evita se a possibilidade de falsos positivos.

Outros ligantes que têm interações competitivas especificamente no mesmo sítio de interação com o analito interferirão apenas em concentrações suficientes para deslocar ou impedir que o analito forme seus complexos. Neste caso, estes interferentes apresentam um efeito sobre a extinção de fluorescência do sensor. Para estes casos, o uso de sensores saturados para descontar a contribuição do analito na supressão total da amostra não é adequado. Assim, a diferença entre a supressão total da amostra e a supressão do sensor saturado não mostram a contribuição destas interferências já que as possibilidades de interações também foram suprimidas pela saturação com o analito.

Para testar esta saturação do sensor, a fração protéica foi incubada com escopolamina (alcalóide agonista muscarínico e anticolinérgico) e amitriptilina (um inibidor da AChE). Eles podem contribuir para a diminuição da fluorescência das proteínas do sensor por sua afinidade pela $\mathrm{AChE}$ e pelos receptores muscarínicos. A amitriptilina (inibidor de AChE usado frequentemente como antidepressivo e sedativo) não teve nenhum efeito sobre a fluorescência do sensor apesar de sua afinidade. No caso da escopolamina, apesar desta substância apresentar efeito de diminuição da fluorescência da fração protéica (Figura 75), na presença de Gal e/ou atropina esse efeito não é observado. Este fato evidencia a perda ou diminuição da afinidade da escopolamina pelas proteínas da fração na presença desses analitos.

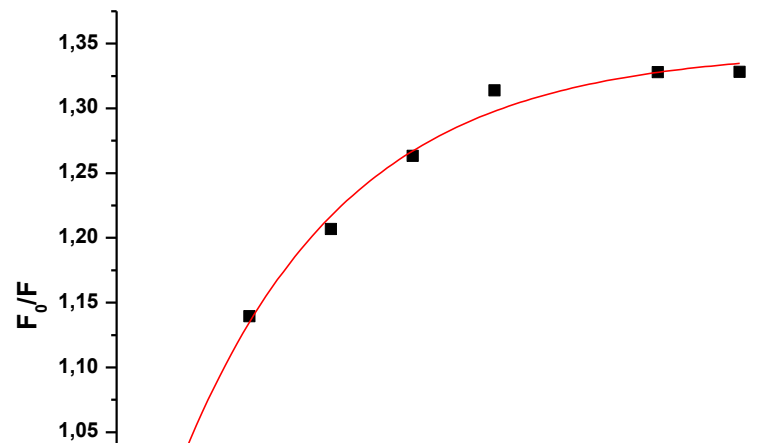


Figura 77 - Efeito de diminuição da fluorescência da escopolamina sobre a fração protéica. A curva exponencial representa essa contribuição mostrando saturação em $16 \mu \mathrm{g} \mathrm{L}^{-1}$.

$\mathrm{Na}$ presença dos analitos, a interferência da escopolamina no sinal de supressão de fluorescência do extrato não foi observada e não afetou significantemente as recuperações obtidas para os cinco analitos em diferentes razões molares entre estes e a escopolamina (até 30 vezes mais escopalamina) como mostrado na Tabela 23 à 24. Apesar de verificar uma pequena diminuição da recuperação dos analitos em razões molares com 30 vezes mais escopolamina, esta diferença não foi significativa ao nível de $5 \%$ (Tabela 25).

Tabela 23-Estudo da interferência de diferentes razões molares analito/escopolamina usando concentração de analito igual a $6,0 \times 10^{-8} \mathrm{~mol} \mathrm{~L}^{1}$

\begin{tabular}{|c|c|c|c|c|c|}
\hline $\begin{array}{c}\text { Razão molar } \\
\text { Analito:escopol } \\
\text { amina }\end{array}$ & \multicolumn{5}{|c|}{ Recuperação (\%) } \\
\cline { 2 - 6 } & Gal & Atrop & Metomil & Metam. & $\begin{array}{c}\text { Metil } \\
\text { paration }\end{array}$ \\
\hline $1: 1$ & 96,1 & 96,5 & 95,8 & 96,3 & 94,2 \\
\hline $1: 15$ & 95,7 & 95,1 & 95,5 & 95,3 & 95,0 \\
\hline $1: 30$ & 90,2 & 91,2 & 93,0 & 90,0 & 91,4 \\
\hline
\end{tabular}

Tabela 24 - Valores médios obtidos para cada analito em soluções na presença de escopolamina. O cálculo das médias foi feito a partir de determinações em triplicata. 


\begin{tabular}{llrll} 
Galantamina & 3 & $1,7 \times 10^{-7}$ & $5,6 \times 10^{-8}$ & $3,9 \times 10^{-18}$ \\
Atropina & 3 & $1,7 \times 10^{-7}$ & $5,6 \times 10^{-8}$ & $2,7 \times 10^{-18}$ \\
Metomil & 3 & $1,71 \times 10^{-7}$ & $5,7 \times 10^{-8}$ & $8,5 \times 10^{-19}$ \\
Metamidofós & 3 & $1,7 \times 10^{-7}$ & $5,6 \times 10^{-8}$ & $4,1 \times 10^{-18}$ \\
M.paration & 3 & $1,7 \times 10^{-7}$ & $5,6 \times 10^{-8}$ & $1,3 \times 10^{-18}$ \\
\hline
\end{tabular}

Tabela 25 - ANOVA das determinações dos cinco analitos para as razões molares (analito: escopolamina) de 1:1; 1:15 e 1:30.

\begin{tabular}{lcccccc}
\hline Fonte da variação & $S Q$ & $g l$ & $M Q$ & $F$ & valor-P & F crítico \\
\hline Entre grupos & $9,2 \times 10^{-19}$ & 4 & $2,3 \times 10^{-19}$ & 0,09 & 0,98 & 3,47 \\
Dentro dos grupos & $2,6 \times 10^{-17}$ & 10 & $2,6 \times 10^{-18}$ & & & \\
Total & $2,7 \times 10^{-17}$ & 14 & & & & \\
\hline
\end{tabular}

Outras drogas como Donepezil e Rivastigmina, utilizadas para tratar a doença de Alzheimer são apenas inibidores fracos da AChE e não atuam como agonistas dos receptores colinérgicos [264]. Portanto, as suas possíveis interações não causam supressão de fluorescência significativas na fluorescência intrínseca da fração protéica nas concentrações encontradas em amostras clínicas.

A seguir são apresentadas as aplicações do método proposto em diferentes matrizes juntamente o estudo de sua seletividade.

\subsection{2.} Aplicação em amostras clínicas e ambientais

Amostras de solo e de urina fortificadas com atropina, galantamina, metomil, metamidofós e metil paration foram usadas para a avaliação do desempenho do método proposto em matrizes ambientais e clínicas.

\subsubsection{1.}

Urina 
Amostras de $10 \mathrm{~mL}$ de urina fresca foram fortificadas com um dos analitos: atropina, galatamina (ambos a 5,6 x 10-6 $\left.\mathrm{molL}^{-1}\right)$, metomil $\left(8,0 \times 10^{-6} \mathrm{molL}^{-1}\right)$, metamidofós $\left(1,2 \times 10^{-5} \mathrm{molL}^{-1}\right)$ e metil paration $\left(3,0 \times 10^{-6} \mathrm{molL}^{-1}\right)$. Cinco alíquotas de $30 \mu \mathrm{L}$ foram retiradas diretamente de cada amostra (sem pré-tratamento) e cada uma foi adicionadas à um sistema com $2,5 \mathrm{~mL}$ de suspensão protéica em tampão fosfato de sódio. Cada um dos sistemas contém a fração saturada com um dos respectivos analitos para realizar o desconto de possíveis interferências. Na Figura 76 é apresentada as curvas construídas para a Gal mostrando a pequena influência de matriz em sua sensibilidade.

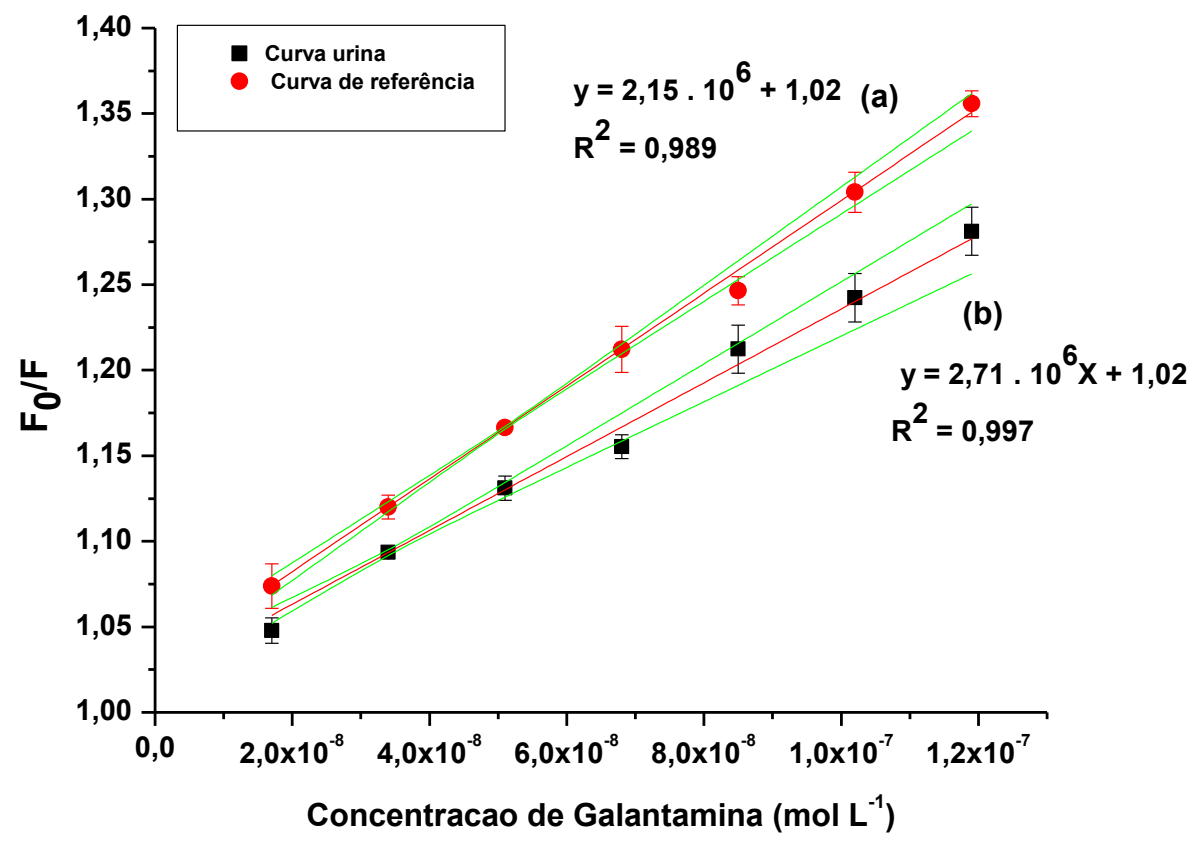

Figura 78- Curvas de titulação da fração protéica com galantamina na faixa de concentração de $2,0 \times 10^{-8}$ à $1,2 \times 10^{-7} \mathrm{~mol} \mathrm{~L}^{-1}$ : (a) curva de referência de Gal em tampão fosfato; (b) adição de $30 \mu \mathrm{L}$ de amostra de urina (in natura) fortificada.

As medições de fluorescência foram feitas como descrito, usando excitação em $280 \mathrm{~nm}$ e emissão em $345 \mathrm{~nm}$. Os valores de intensidade de fluorescência de cada sistema com o sensor foram usados para os cálculos segundo mostrado na Tabela 25. Para o cálculo da supressão total de fluorescência causada pela amostra 
$\left(\Delta \mathrm{F}_{\text {total }}\right)$, a intensidade da fração protéica livre é medida antes $\left(\mathrm{F}_{0 \text { Livre }}\right)$ e depois da adição da alíquota da amostra $\left(\mathrm{F}_{a m}\right)$.

A cada sistema contendo a respectiva fração saturada $\left(\mathrm{F}_{0 \text { sat }}\right)$ é adicionada igual alíquota da amostra e feita nova medição da fluorescência. A contribuição de cada analito na diminuição de fluorescência da fração protéica $\left(\Delta \mathbf{F}_{\text {analito }}\right)$ foi medida pela diferença entre a supressão da fração livre $\left(\Delta \mathbf{F}_{\text {total }}\right)$ e a supressão do sinal da fração saturada $\left(\Delta \mathrm{f}_{\text {sat }}\right)$. Para que todos os sistemas saturados tenham o mesmo valorr de $\mathrm{F}_{0}$ (antes da saturacão), todas as frações foram obtidas de uma mesma fração protéica (estoque). Entretanto, esta contribuição individual em termos de diferença de sinal fluorescente $(\Delta \mathrm{F})$ não pode ser utilizada na interpolação da curva analítica de supressão. Por isso, realizou-se sua conversão para valores da razão $F_{0} / F$, considerando $\mathrm{F}_{0}$ como o sinal da fração livre (antes da adição da amostra) e $\mathrm{F}$ o valor estimado do sinal somente com a contribuição do respectivo analito. Em seguida a concentração da amostra pôde ser calculada pela interpolação do valor estimado de $\mathrm{F}_{0} / \mathrm{F}$ na curva de Stern-Volmer para cada analito. Na tabela 26 é decrito o cálculo para estimar a contribuição individual dos analitos sobre a resposta de fluorescência do total das proteínas da fração de cérebro.

Tabela 26 - Cálculo para a determinação seletiva dos analitos através da estimação da contribuição individual dos analitos sobre a supressão total de fluorescência.

\begin{tabular}{|c|c|c|c|c|c|}
\hline \multicolumn{6}{|c|}{ Sensor Livre } \\
\hline \multicolumn{6}{|c|}{$\Delta \mathbf{F}_{\text {total }}=\mathbf{F}_{0 \text { Livre }}-\mathbf{F}_{a m}$} \\
\hline \multicolumn{6}{|c|}{$980-285=695$} \\
\hline \multicolumn{6}{|c|}{ Sensor saturado } \\
\hline Analitos & $\mathbf{F}_{\text {osat }}-\mathbf{F}_{\text {sat (am })}=\Delta \mathbf{f}_{\text {sat }}$ & $\begin{array}{l}\Delta \mathbf{F}_{\text {total }} \\
\Delta \mathbf{f}_{\text {sat }}=\Delta \mathbf{F}_{\text {analito }}\end{array}$ & $\begin{array}{l}\mathrm{F}_{0}- \\
\Delta \mathbf{F}_{a} \\
\text { nalito }\end{array}$ & $\begin{array}{c}\mathbf{F}_{0} / \mathbf{F} \\
\text { (estimado } \\
\text { ) }\end{array}$ & $\begin{array}{l}\text { Concent. } \\
\text { estimada } \\
\left(\mathrm{mol} \mathrm{L}^{-1}\right)\end{array}$ \\
\hline Gal & $600-258=342$ & $695-342=\mathbf{3 5 3}$ & 627 & $980 / 627$ & $6,7 \times 10^{-8}$ \\
\hline Atr & $700-149=551$ & $695-551=\mathbf{1 4 4}$ & 836 & $980 / 836$ & $6,7 \times 10^{-8}$ \\
\hline Met & $705-478=227$ & $695-468=\mathbf{2 2 7}$ & 753 & $980 / 753$ & $1,0 \times 10^{-9}$ \\
\hline M.P & $636-84=552$ & $695-552=\mathbf{1 4 3}$ & 837 & $980 / 837$ & $3,5 \times 10^{-8}$ \\
\hline
\end{tabular}

Foi realizada uma comparação estatística entre as determinações médias obtidas pelo método proposto e o método cromatográfico (HPLC-F-UV) em seis amostras fortificadas com 1,5 x 10-8 $\mathrm{mol} \mathrm{L}^{-1}$ (Gal ou atropina), $1,0 \times 10^{-7} \mathrm{~mol} \mathrm{~L}^{-1}$ 
(metomil, metamidofós) e 2,6 x $10^{-6} \mathrm{~mol} \mathrm{~L}^{-1}$ (metil paration). Na Figura 78 é apresentado o cromatograma da amostra de urina fortificada e as medidas nos diferentes comprimentos de onda.

Foi aplicado o teste t de Student cujo resultado é apresentado nas Tabelas 27 à 29, indicando que não houve diferença estatística entre os resultados obtidos pelo método proposto e o de comparação para os analitos considerados.

Tabela 27 - Resultado do teste $t$ de Student para a comparação de médias dos dois métodos de determinação de Gal (proposto e HPLC).

\begin{tabular}{lcc}
\hline & $\begin{array}{c}\text { Método } \\
\text { proposto }\end{array}$ & HPLC \\
\hline Média & $1,43 \times 10^{-8}$ & $1,51 \times 10^{8}$ \\
Variância & $4,7 \times 10^{-18}$ & $2,1 \times 10^{-18}$ \\
Observações & 6 & 6 \\
Variância agrupada & $3,4 \times 10^{-18}$ & \\
Gl & 10 & \\
Statística t & $-0,78$ & \\
t crítico bi-caudal & 2,22 & \\
\hline
\end{tabular}

Tabela 28 - Resultado do teste $t$ de Student para a comparação de médias dos dois métodos de determinação de metomil (proposto e HPLC).

\begin{tabular}{lcc}
\hline & Método proposto & HPLC \\
\hline Média & $1,2 \times 10^{-7}$ & $1,1 \times 10^{-7}$ \\
Variância & $2,6 \times 10^{-16}$ & $1,8 \times 10^{-16}$ \\
Observações & 6 & 6 \\
Variância agrupada & $2,2 \times 10^{-16}$ & \\
Hipótese da diferença de média & 0 & \\
Gl & 10 & \\
Estatística t & 0,78 & \\
t crítico bi-caudal & 2,23 & \\
\hline
\end{tabular}

Tabela 29 - Resultado do teste $t$ de Student para a comparação de médias dos dois métodos de determinação de metil paration (proposto e HPLC-FDAD).

\begin{tabular}{ccc}
\hline & Método proposto & HPLC \\
\hline Média & $2,4 \times 10^{-6}$ & $2,53 \times 10^{-6}$
\end{tabular}




\begin{tabular}{lcc} 
Variância & $6,1 \times 10^{-14}$ & $1,5 \times 10^{-14}$ \\
Observações & 6 & 6 \\
Variância agrupada & $3,8 \times 10^{-14}$ & \\
gl & 10 & \\
Estatística t & $-1,06$ & \\
t crítico bi-caudal & \multicolumn{2}{c}{2,22}
\end{tabular}

A Tabela 30 apresenta os valores de recuperação para os analitos obtidos por ambos os métodos. Os resultados de recuperação acima de $88 \%$ mostram que o método por extinção de fluorescência são satisfatóriose indicam sua viabilidade para ser aplicado em amostras de urina.

Tabela 30 - Taxa de recuperação dos analitos nas amostras de urina pelo método proposto e o de referência.

\begin{tabular}{ccc}
\hline Analito & $\begin{array}{c}\text { Taxa de recuperação } \\
\text { (método proposto) }\end{array}$ & $\begin{array}{c}\text { Taxa de recuperação } \\
\text { (HPLC) }\end{array}$ \\
\hline Galantamina & $89,2 \%$ & $92,6 \%$ \\
\hline Atropina & $90,1 \%$ & $95,5 \%$ \\
\hline Metomil & $92,6 \%$ & $94,7 \%$ \\
\hline Metamidofós & $87,5 \%$ & - \\
\hline Metil paration & 92,7 & $97,3 \%$ \\
\hline
\end{tabular}

Pela incapacidade de detectar os níveis de metamidofós pelo método de cromatografia líquida empregado, adotou-se o método enzimático [255]como método de referência para a determinação deste agrotóxico. Este método se baseia na inibição da atividade catalítica da AChE para a quantificação dos inibidores. $\mathrm{Na}$ figura 77 é apresentado a curva de inibição utilizada como curva analítica por este método. Realizou-se também a determinação das concentrações de metil paration nas mesmas amostras para possibilitar uma comparação com o método cromatográfico. A curva de inibição da atividade da AChE pelos analitos foi utilizada como curva analítica pela linearização da função exponecial típica do comportamento de inibição enzimática. A figura 79 apresenta a curva analítica da porcentagem de inibição da aividade da AChE contra o logarítimo natural da concentração dos organofosforados na faixa de 5,0 x $10^{-8}$ à $45 \times 10^{-8} \mathrm{~mol} \mathrm{~L}^{-1}$. 


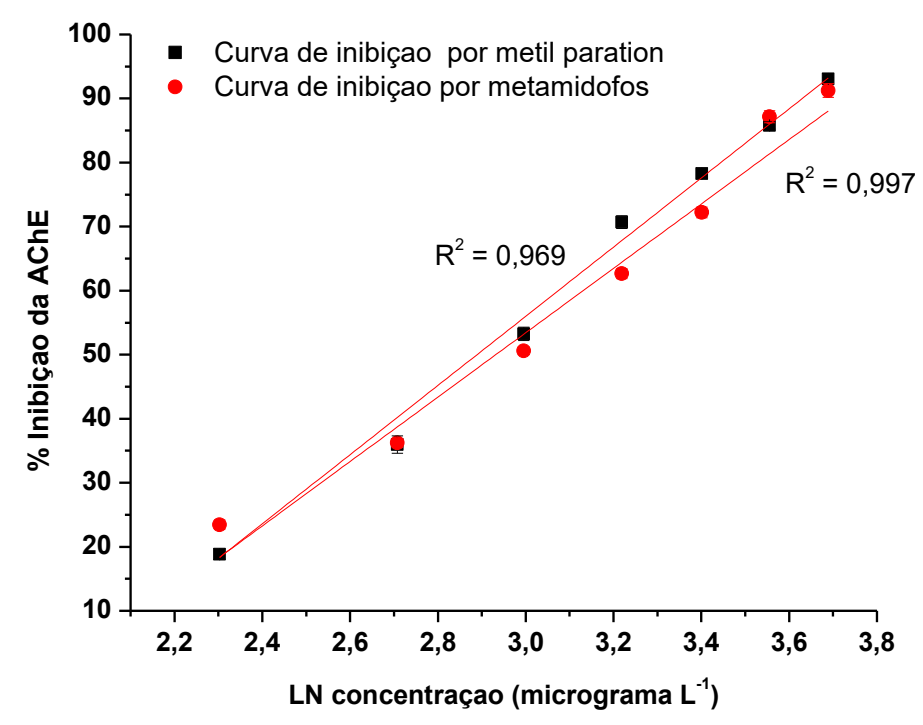

Figura 79 - Curva de inibição da AChE pelos organofosforados metamidofós e metil paration na faixa de concentração de 5,0 x $10^{-8}$ à 45 x $10^{-}$ 8 mol L-1.

$\mathrm{Na}$ Tabela 31 são apresentadas as recuperações para ambos os analitos pelo método proposto e os de referência. Em urina a recuperação foi maior que $88 \%$ para os dois organosforados.

Tabela 31 - Valores de \% recuperação para as determinações de metamidofós e metil paration.

\begin{tabular}{llccc}
\hline \multicolumn{1}{c}{ Matrizes } & Analitos & $\begin{array}{c}\text { Recuper. } \\
\text { (Fluorescência) }\end{array}$ & $\begin{array}{c}\text { Recuper. } \\
\text { (Cinético) }\end{array}$ & $\begin{array}{c}\text { Recuper. } \\
\text { (HPLC) }\end{array}$ \\
\hline \multirow{2}{*}{ Urina } & Metamidofós & $88,2 \%$ & $92,3 \%$ & - \\
\cline { 2 - 5 } & Metil paration & & $87,3 \%$ & $92,5 \%$
\end{tabular}

4.5.2.2.

Solo

As determinações para validação do método proposto para solos foram realizadas após a fortificação das amostras com $1 \mathrm{mg} \mathrm{kg}^{-1}$ dos agrotóxicos metomil (Lannate ${ }^{\circledR}$ - DuPont), metamidofós (Tamaron $\AA^{\circledR}$ - Bayer) e metil paration (Folidol® - Bayer). 
Caracterização das amostras

As amostras foram coletadas em áreas de cobertura florestal em duas profundidades $(0-10 \mathrm{~cm}$ e $10-20 \mathrm{~cm})$ representando as camadas aráveis que estão diretamente em contato com os agrotóxicos. Estas foram caracterizadas segundo os parâmetros de fertilidade de solos (teor de macronutrientes $-\mathrm{Ca}^{2+}, \mathrm{Mg}^{2+}, \mathrm{K}^{+}$e P assimilável), teor de carbono orgânico e nitrogênio total. Também considerou-se o perfil textural dos solos por sua importância no comportamento adsortivo dos analtitos à matriz (Tabela 32) A escolha de amostras em área de floresta para as fortificacões se deve a menor possibilidade da presença de possíveis residuos de agrotóxicos na matriz antes da fortificação. Acredita-se que a baixa saturação do complexo sortivo do solo (representado pela soma dos teores dos cátions/macronutrientes) e seu perfil arenoso não comprometeram a recuperação dos analitos nesta matriz.

Tabela 32 - Valores dos parâmetros de fertilidade de solos para as amostras florestais coletadas em duas profundidades em área de cobertura vegetal. ( $P$ ass. - fósforo assimilável)

\begin{tabular}{cccccccc}
\hline \multirow{2}{*}{ AMOTRAS } & $\begin{array}{c}\text { Classe } \\
\text { textural }\end{array}$ & $\mathbf{P}$ ass. & $\mathbf{C a}^{2+}$ & $\mathbf{M g}^{2+}$ & $\mathbf{K}^{+}$ & $\mathbf{A l}^{3+}$ & $\begin{array}{c}\mathbf{C} \\
(\text { orgânico) } \\
\mathbf{g} / \mathbf{k g}\end{array}$ \\
\hline$(0-10 \mathrm{~cm})$ & Arenoso & 8 & 0,2 & 0,5 & 0,15 & 1,0 & 17,6 \\
\hline$(10-20 \mathrm{~cm})$ & Arenoso & 7 & 0 & 0,2 & 0,04 & 0,7 & 9,8 \\
\hline
\end{tabular}

\section{Determinação}

As amostras de solo foram fortificadas com os três analitos (agrotóxicos)e depois foram submetidas à extração com acetona. Em seguida os extratos foram evaporados até secura e ressuspensos em 2,0 mL de tampão fosfato. Para um estudo da seletividade do sensor no extrato de solo adicionou-se ao extrato ressuspenso em tampão Gal e atropina à concentração de $1,5 \times 10^{-8} \mathrm{~mol} \mathrm{~L}^{-1}$. Apesar destes dois 
analitos não terem sido extraídos da amostra considerou-se importante avaliar a seletividade da sonda na presença de todos so inibidores estudados.

Uma alíquota de $250 \mu \mathrm{L}$ foi adicionada à suspensão da fração protéica em tampão. Da mesma forma que para as amostras de urina, cada um dos sistemas continha ossensores saturados com um dos analitos. Os cálculos para a determinação dos analitos são iguais aos realizados para a amostra de urina (Tabela 26).Apesar da etapa de extração com acetona extrair também material humificado (ácidos húmicos) contidos nas amostras, estes não interferiram no espectro de emissão de fluorescência da fração protéica obtida en 280/345 nm já que a emissão de fluorescência dos ácidos orgânicos ocorre em torno de $350 \mathrm{~nm}$ (excitação) e 445 nm (emissão) [289]. Na Figura 78 são mostrados os espectros da suspensão protéica após a ressuspensão do extrato de solo em dois comprimentos de onda de excitação otimizados para a fração de proteína total $(280 \mathrm{~nm})$ e para os ácidos orgânicos presentes no extrato de solo $(380 \mathrm{~nm})$.

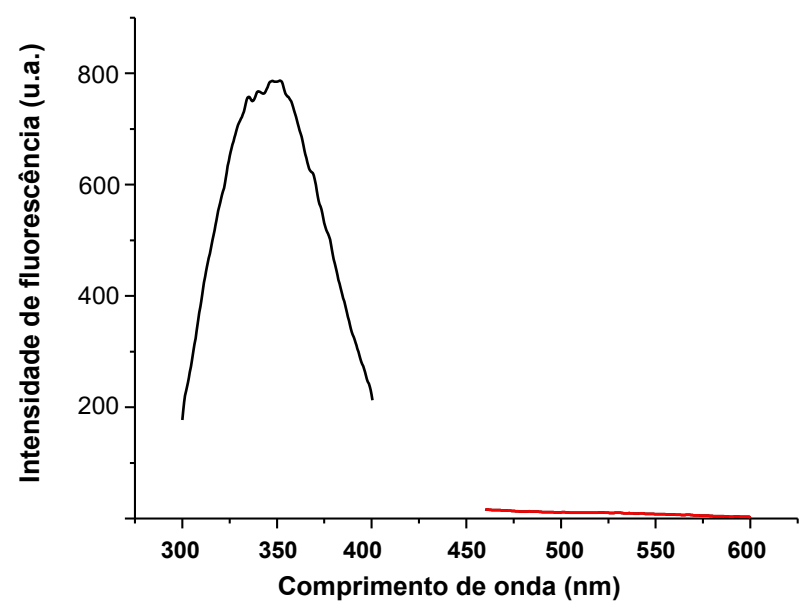

Figura 80-Espectro da suspensão da fração protéica em tampão fosfato após a ressuspensão de $250 \mu \mathrm{L}$ do extrato de solo $(0-10 \mathrm{~cm})$. A linha preta se refere à excitação em $280 \mathrm{~nm}$ e a vermelha em $380 \mathrm{~nm}$.

O mesmo extrato de solo (ressuspenso em tampão) foi utilizado para as determinações pelo método cromatográfico de referência que utilizou a detecção 
por fotometria de absorção multicanal com o DAD para a identificação dos analitos. Na Figura 81 é apresentado o cromatograma em multicanais da amostra de urina. A detecçãofoi realizada em diferentes comprimentos de onda que permitem aquantificação de cada composto separadamente.

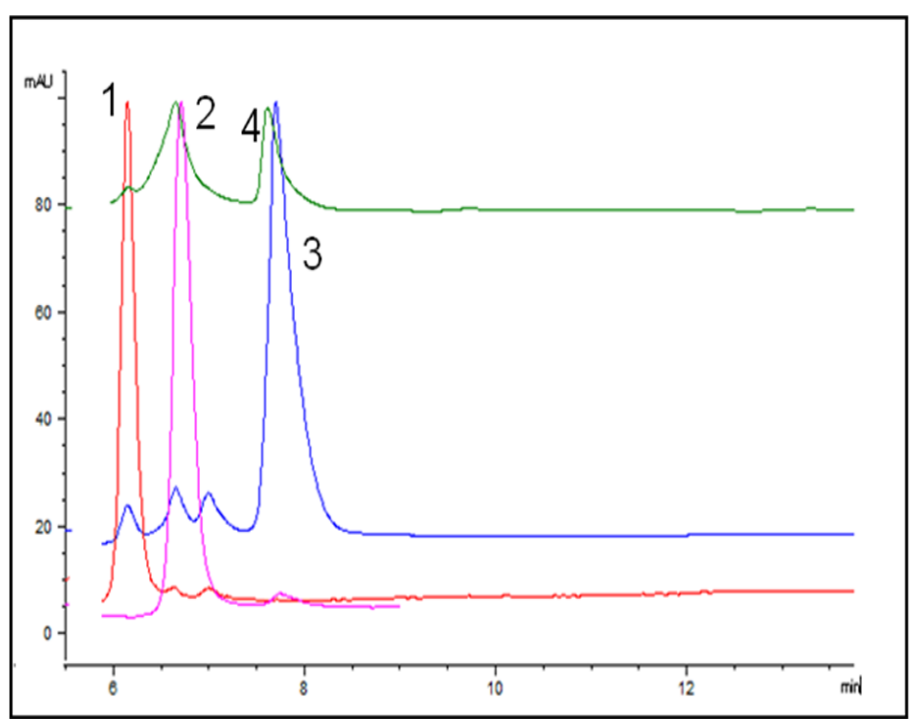

Figura 81- Cromatogramade amostra de urina fresca fortificada com os analitos(1) metomil, (2)Gal, (3) atropina, (4) metil paration.

A Tabela 33 apresenta os valores de recuperação obtidos dos extratos de solos para o método proposto e por HPLC. O teste t de comparação de médias foi aplicado aos dois conjuntos de determinações indicando igualdade estatística nos resultados das recuperações. Observa-se que as recuperações pelo métodos proposto ficaram acima de $94 \%$. Este resultado indica que os procedimentos de extração e de quantificação adotados são adequados para determinações em matrizes de solo de uso agrícola. $O$ teor de matéria orgânica presente na matriz de solo não causou interferências que comprometessem o desempenho satisfatório do processo de extração (poder de adsorção dos resíduos) e do método por fluorescência. Para as amostras de solo de $20-40 \mathrm{~cm}$ as recuperações ficaram acima de $96 \%$ (método proposto) e sem diferença significativa das obtidas pelo método cromatográfico (em torno de $98 \%$ ) com valor de $\mathrm{T}$ (teste $\mathrm{T}$ de student) igual a 0,76 . 
Tabela 33 - Valores de recuperação dos 3 analitos nas 2 profundidades: método proposto e o método cromatográfico de referência. Valor médio de dez replicatas e desvios menores que $2,5 \%$.

\begin{tabular}{cccccc}
\hline Analito & $\begin{array}{c}\text { Método } \\
\text { proposto } \\
\text { (média) }\end{array}$ & Recuper. & $\begin{array}{c}\text { HPLC } \\
\text { (média) }\end{array}$ & Recuper. & $\begin{array}{c}\text { Estatística } \\
\text { T }\end{array}$ \\
\hline $\begin{array}{c}\text { Metomil } \\
\left(\mathrm{mg} \mathrm{Kg}^{-1}\right)\end{array}$ & 0,94 & $94 \%$ & 0,99 & $99 \%$ & $-0,60$ \\
\hline $\begin{array}{c}\text { Metil } \\
\text { paration } \\
\left.(\mathrm{mg} \mathrm{Kg})^{-1}\right)\end{array}$ & 0,97 & $97 \%$ & 0,98 & $98 \%$ & $-0,25$ \\
\hline $\begin{array}{c}\text { Galantamina } \\
(\text { mol L }\end{array}$ & $1,46 \times 10^{-8}$ & 97,3 & $1,49 \times 10^{-8}$ & $99,3 \%$ & $-2,48$ \\
\hline $\begin{array}{c}\text { Atropina } \\
(\text { mol L }\end{array}$ & $1,45 \times 10^{-8}$ & 96,7 & $1,40 \times 10^{-8}$ & $93,3 \%$ & 0,71 \\
\hline T crítico & 2,22 & & & \\
\hline
\end{tabular}

Na Tabela 34 é apresentada a \% de recuperação do método proposto e pelos métodos de referência (cromatográfico e cinético) nas determinações de metamidofós e metil paration em amostras de solo e urina. Os valores médios ficaram acima de $90 \%$ (fluorescência) para ambos os analitos.

Tabela 34 - Valores de \% de recuperação obtidas para a determinação de metamidofós e metil paration pelo método proposto (fluorescência) e os dois métodos de referência: cromatográfico e o cinético.

$\begin{array}{ccccc}\text { Matrizes } & \text { Analitos } & \begin{array}{c}\text { Recuper. } \\ \text { (Fluorescência) }\end{array} & \begin{array}{c}\text { Recuper. } \\ \text { (Cinético) }\end{array} & \begin{array}{c}\text { Recuper. } \\ \text { (HPLC) }\end{array}\end{array}$




\begin{tabular}{lllll}
\hline Solo & Metamidofós & $92,4 \%$ & $95,3 \%$ & - \\
\cline { 2 - 4 } & Metil paration & $91,5 \%$ & \\
\hline
\end{tabular}

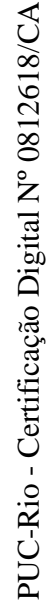




\section{5 \\ Conclusão}

A utilização da fração protéica obtida de cérebro de rato como sonda seletiva para determinação de agrotóxicos foi satisfatória. Os mecanismos de bioreconhecimento entre a sonda e os analitos permitiram que o método para sua determinação fosse desenvolvido com sensibilidade e seletividade apropriada em amostras ambientais e clínicas sem pré-tratamento:O desempenho analítico da fração protéica de cérebro de rato se mostrou eficiente em comparação à sondas puras (fração purificada). O processo de extração/purificação elaborado pretendeu obter uma fração composta de elementos protéicos com certa afinidade seletiva pelos analitos. Dessa forma, foi possível potencializar/aumentar o número de interações com receptores de membrana e com a enzima acetilcolinesterarase.

Pelo alto custo e/ou difícil obtenção de material de natureza protéica como enzimas e proteínas estruturais (como os neuroreceptores de membrana) os sistemas analíticos baseados no bioreconhecimento proteína-ligantes empregam estratégias de imobilização e reativação das sondas para aumentar o numero de amostras processadas. Nesta proposta procurou-se simplificar o processo de obtenção da sonda e a diminuição de gasto deste material para que este não seja limitante à aplicação do método. Adotou-se um princípio de medição sensível às interações com pequenas concentrações dos analitos. Além disso, as medidas de supressão de fluorescência, expressas na forma de razão $\mathrm{F}_{0} / \mathrm{F}$ permitiram o uso da fluorescência das proteínas totais do extrato sem perda de sensibilidade. $\mathrm{O}$ emprego da variação de sinal de fluorescência (supressão) também conferiu seletividade nas determinações dos analitos mesmo com um biocomponente obtido de forma simples e com um baixo custo.

Para a detecção dos analitos explorou-se as propriedades espectroscópicas das proteínas já utilizadas para estudos de afinidades por ligantes. Os ensaios utilizando biosondas fluorescentes tem ampla aplicação na área biológica pelas facilidades operacionais aliadas à sensibilidade à segurança na manipulação e descarte de reagentes. A caracterização espectroscópica do mecanismo de 
bioreconhecimento sonda-analito permitiu o desenvolvimento dos métodos e o estudo sobre as reais interferências. Pode-se construir um procedimento para o cálculo da estimativa da contribuição de cada analito à diminuição do sinal total de fluorescência da sonda sem o uso de ferramentas estatísticas para se eliminar interferências. Portanto, obteve-se um biosensor protéico sem as limitações comun de limitada seletividade.

A utilização do planejamento experimental multivariado na otimização das condições de medição do sinal de fluorescência da sonda foi uma abordagem nova para o estudos de ligantes. Este tratamento atendeu à necessidade de uma avaliação simultânea dos parâmetros dos quais depende o comportamento de interação das proteínas. Dessa forma foi possível determinar as melhores condições de ensaios com os ligantes (analitos) e comparar sua resposta com os ensaios cinéticos da AChE que já são utilizados como método de biodetecção destes mesmos analitos. Ao mesmo tempo, este procedimento pode ser aplicado em estudos biológicos para definição de modelos empíricos de interação com drogas e moléculas bioreguladoras, por exemplo.

A adaptação do método proposto à um sistema de biosensor com uso de uma sonda extrínseca (Tioflavina T) também foi avaliado. Os resultados indicaram que a fração protéica extraída de cérebro de rato pode ser imobilizada em microplaca para as medidas de fluorescência na determinação dos analitos sem prejuízo dos parâmetros analiticos. Ao mesmo tempo, pode-se utilizar a própria tioflavina T para medidas indiretas das interações dos analitos com a fração protéica.

Paralelo aos objetivos de quantificação de substâncias de interesse, existe a necessidade de desenvolver ensaios utilizando extratos/homogenatos biológicos para estudos em sistemas complexos. Entretanto estes são limitados pela falta de sensibilidade às quantidades dos ligantes empregados em matrizes celulares e teciduais. Assim, a respostada fluorescência intrínseca do próprio material biológico pode ser avaliadaconjuntamente com a respostas de sistemas purificados. 


\section{6 Referências bibliográficas}

\section{REFERENCIAS}

1. Relatório da Health Protection Agency, 2007 - Disponível em http://www.nationaltoxic-encephalopathy-foundation.org/chemneuro.pdf - Acessado em 12/01/2011

2. WINNEKE, G. Appraisal of neurobehavioral methods in environmental health research: The developing brain as a target for neurotoxic chemicals. International Journal of Hygiene and Environmental Health, v. 210, n. 5, p. 601-609, 2007.

\section{LANDRIGAN, P. J.; GRAHAM, D. G.; THOMAS, R. D. Strategies for the} Prevention of Environmental Neurotoxic Illness. Environmental Research, v. 61, n. 1, p. 157-163, 1993.

4.CLAUDIO, L. et. al..Testing methods for developmental neurotoxicity of environmental chemicals. Toxicol Appl Pharmacol. 2000 Apr 1;164(1):1-14

5. LANNA, A. C. Impacto ambiental de tecnologias, indicadores de sustentabilidade e metodologias de aferição : uma revisão / Anna Cristina Lanna. - Santo Antônio de Goiás : Embrapa Arroz e Feijão, 2002. 31 p. (Documentos / Embrapa Arroz e Feijão, ISSN 1678- 9644 ; 144)

6. ORGANIZAÇÃO PAN-AMERICANA DA SAÚDE (Representação do Brasil). Manual de Vigilância da Saúde de Populações Expostas a agrotóxicos. Brasília, 1996

7. Reportagem Folha de S. Paulo disponível em http://pratoslimpos.org.br/?tag=anvisa em 10/07/2012 
8. Relatório de atividades- PROGRAMA DE ANÁLISE DE RESÍDUOS DE AGROTÓXICOS EM ALIMENTOS (PARA) - ANVISA Disponível em http://portal.anvisa.gov.br/wps/wcm/connect/b380fe004965d38ab6abf74ed75891a e/Relat\%C3\%B3rio+PARA+2010++Vers\%C3\%A3o+Final.pdf?MOD=AJPERES - Data de acesso: 11/04/2012

9. BRASIL. LEI FEDERAL N 7.802 DE 11 DE JULHO DE 1989. Dispõe sobre a pesquisa, a experimentação, a produção, a embalagem e rotulagem, o transporte, o armazenamento, a comercialização, a propaganda comercial, a utilização, a importação, a exportação, o destino final dos resíduos e embalagens, o registro, a classificação, o controle, a inspeção e a fiscalização de agrotóxicos, seus componentes e afins. Disponível em: http://www.planalto.gov.br/ccivil/LEIS/L7802.htmData de acesso: 23 de julho de 2006.

10. MATTSON, M. P.; MAGNUS, T. Ageing and neuronal vulnerability. Nature Reviews Neuroscience, v. 7, n. 4, p. 278-294, 2006.

11. SANTOS, S.P., A Química dos Inseticidas (parte I). Boletim SPQ Química dos Inseticidas, p.43-47. 2001

12. BARBOSA, A.C. EAST, G.P e ORNELAS R.B.,.Agentes sociais procedimentos e Ferramentas.

http://www.ibama.gov.br/ambtec/documentos/Parte\%204.pdf. Data de acesso: 26 mar.2008.

13. WESSELING, C. et al. Long-term neurobehavioral effects of mild poisonings with organophosphate and n-methyl carbamate pesticides among banana workers. International Journal of Occupational and Environmental Health, v. 8, n. 1, p. 27-34, 2002. 
14. Directiva 76/464/CEE do Conselho, de 4 de Maio de 1976, relativa à poluição causada por determinadas substâncias perigosas lançadas no meio aquático da Comunidade. Disponível em

http://eurlex.europa.eu/LexUriServ/LexUriServ.do?uri=CELEX:31976L0464:PT:HT ML acessado em 12/12/2011

15. "Directive 2000/60/EC of the European Parliament and of the Council establishing a framework for the Community action in the field of water policy"disponivel em : $\quad$ http://ec.europa.eu/environment/water/waterframework/index_en.html

16. HILDEBRANDT, A. et al. Development of a portable biosensor for screening neurotoxic agents in water samples. Talanta, v. 75, n. 5, p. 1208-1213, 2008.

17. KAMRIN, M. (ed.). Pesticides profiles - toxicity, environmental impact, and fate. New York: Boca Raton, 2000.

18. FAO. 2002 Food and agriculture organization of the united nations (FAO) Specifications and evaluations for plant protection products. Methomyl, $25 \mathrm{p}$. DIsponível em: $<<$ http://www.fao.org/ag/agp/agpp/Pesticid/Specs/docs/Pdf/new/methomyl.pdf $>>$. Acessado em: 03 de ago. de 2007

19. Bergs, K.Z.H., Clinical and Post Mortem Aspects of Methomyl Intoxication . Disponivel em http://igitur-archive.library.uu.nl/student-theses/2010-0630200151/UUindex.html

20. ANVISA. Sistema de Informação sobre Agrotóxicos (ANVISA) Relatório $\begin{array}{llll}\text { do } & \text { Agrotóxico. } & \text { Disponível }\end{array}$ <http://www4.anvisa.gov.br/AGROSIA/asp/frm_dados_agrotoxico.asp?iVarAux= 1\&MarcaCod=79> Acesso em: 02 de out. 2007.

21. CALDAS,L.Q.A. (coord.) Intoxicações axógenas agudas por carbamatos, organofosforados, compostos bipiridílicos e piretróides - Centro de Controle de 
Intoxicações ed Niterói - RJ (Hospital Universitário Antônio Pedro/Universidade Federal Fluminense.), 2000.

22. CASARRET, L.J., DOULL, J.(1991) Toxicology. In: M.O. Amdur, J. Doull and C.D. Klaassen (Eds), The Basic Science of Poisons, 4a ed., Pergamon Press Inc., New York.

23. NORTON, T. R. (1975). Metabolism of toxic substances. In: "Toxicology - The Basic Science of Poisons", 768 pp.Casarett, L. J. e Doull, J. ed., Macmillan Publishing Co. New York.

24.MAIN, A. R. (1976). Structure and Inhibitors of Cholinesterase. In: Biology of Cholinergic Function, pp. 269-353. Goldberg A. M. e Hamim, I., Raven Press, New York.

25. FORSYTH, C. S.; CHAMBERS, J. E. Activation and Degradation of the Phosphorothionate Insecticides Parathion and Epn by Rat-Brain. Biochemical Pharmacology, v. 38, n. 10, p. 1597-1603, 1989.

26. FRANKLIN, R. B. et al. Comparative Aspects of the Disposition and Metabolism of Xenobiotics in Fish and Mammals.Federation Proceedings, v. 39, n. 13, p. 3144-3149, 1980.

27. GILlETTE, J. R.; SASAME, H. A.; DAVIS, D. C. Cytochrome-P-450 and Its Role in Drug-Metabolism.Annual Review of Pharmacology, v. 12, p. 57-\&, 1972.

28. LEWIS, D. F. V.; IOANNIDES, C.; PARKE, D. V. Molecular-Orbital Studies of Oxygen Activation and Mechanisms of Cytochromes-P-450-Mediated Oxidative-Metabolism of Xenobiotics.Chemico-Biological Interactions, v. 70, n. 3-4, p. 263-280, 1989.

29. SATO, R. Cytochrome-P-450 - an Inconspicuous Start - a Citation-Classic Commentary on the Carbon Monoxide-Binding Pigment of Liver-Microsomes .1. 
Evidence for Its HemoproteinNature.Current Contents/Life Sciences, n. 8, p. 99, 1991.

30. WILliAMS, F. M.; MUTCH, E.; BLAIN, P. G. Esterase-Activity in Rat Hepatocytes.Biochemical Pharmacology, v. 41, n. 4, p. 527-531, 1991.

31. CHAMBERS, J. E.; MUNSON, J. R.; CHAMBERS, H. W. Activation of the Phosphorothionate Insecticide Parathion by Rat-Brain Insitu.Biochemical and Biophysical Research Communications, v. 165, n. 1, p. 327-333, 1989.

32. MOURA, C.M. Metodologia enzimática para a detecção de pesticidas organofosforados e carbamatos em água e frutas. Dissertação de Mestrado Universidade do Estado do Rio de Janeiro (UERJ)- 1998.

33. DAUGhTON, C. G.; TERNES, T. A. Pharmaceuticals and personal care products in the environment: agents of subtle change? Environmental health perspectives, v. 107 Suppl 6, p. 907-938, 1999.

34. HEBERER, T. Occurrence, fate, and removal of pharmaceutical residues in the aquatic environment: a review of recent research data. Toxicology Letters, v. 131, n. 1-2, p. 5-17, 2002.

35. RICHARDSON, M. L.; BOWRON, J. M.The Fate of Pharmaceutical Chemicals in the Aquatic Environment.Journal of Pharmacy and Pharmacology, v. 37, n. 1, p. 1-12, 1985.

36.HALLING-SORENSEN, B. et al. Occurrence, fate and effects of pharmaceutical substances in the environment - A review.Chemosphere, v. 36, n. 2, p. 357-394, 1998.

37. TERNES, T. A. Occurrence of drugs in German sewage treatment plants and rivers.Water Research, v. 32, n. 11, p. 3245-3260, 1998. 
38. KUMMERER, K.; AL-AHMAD, A.; MERSCH-SUNDERMANN, V. Biodegradability of some antibiotics, elimination of the genotoxicity and affection of wastewater bacteria in a simple test. Chemosphere, v. 40, n. 7, p. 701-710, 2000.

39. CARLSSON, C. et al. Are pharmaceuticals potent environmental pollutants? Part I: Environmental risk assessments of selected active pharmaceutical ingredients. Science of the Total Environment, v. 364, n. 1-3, p. 67-87, 2006.

40. DAUGHTON, C. G.; TERNES, T. A. Pharmaceuticals and personal care products in the environment: agents of subtle change? Environmental health perspectives, v. 107 Suppl 6, p. 907-938, 1999.

41. HEBERER, T. Occurrence, fate, and removal of pharmaceutical residues in the aquatic environment: a review of recent research data. Toxicology Letters, v. 131, n. 1-2, p. 5-17, 2002.

42. STUMPF, M.; TERNES, T. A.; WILKEN, R.; RODRIGUES, S. V.; BAUMANN, W. Polar drug resides in sewage and natural waters in the state of Rio de Janeiro, Brazil. Science Total Environmental, v. 222, p. 135, 1999.

43. TERNES, T. A. Occurrence of drugs in German sewage treatment plants and rivers. Water Research, v. 32, n. 11, p. 3245-3260, 1998.

44. TERNES TA, KRECKEL P, MUELLER J.Behaviour and occurrence of estrogens in municipal sewage treatment plants - II. Aerobic batch experiments with activated sludge. Science Total Environmental, 225:91-99, 1999.

45. KOLPIN, D. W. et al. Pharmaceuticals, hormones, and other organic wastewater contaminants in US streams, 1999-2000: A national reconnaissance. Environmental Science \& Technology, v. 36, n. 6, p. 1202-1211, 2002.

46. STACKELBERG, P. E. et al. Persistence of pharmaceutical compounds and other organic wastewater contaminants in a conventional drinking-watertreatment plant. Science of the Total Environment, v. 329, n. 1-3, p. 99-113, 2004. 
47. WILLIAMS, M. et al. Can aquatic distribution of human pharmaceuticals be related to pharmacological data? Chemosphere, v. 65, n. 11, p. 2253-2259, 2006.

48. THIELE-BRUHN, S. Pharmaceutical antibiotic compounds in soils - a review. Journal of Plant Nutrition and Soil Science-Zeitschrift Fur Pflanzenernahrung Und Bodenkunde, v. 166, n. 2, p. 145-167, 2003.

49. SARMAH, A. K. et al. Parameter estimation through inverse modelling and comparison of four leaching models using experimental data from two contrasting pesticide field trials in New Zealand.Australian Journal of Soil Research, v. 44, n. 6, p. 581-597, 2006.

50. LOPEZ-SERNA, R.; PETROVIC, M.; BARCELO, D. Development of a fast instrumental method for the analysis of pharmaceuticals in environmental and wastewaters based on ultra high performance liquid chromatography (UHPLC)tandem mass spectrometry (MS/MS). Chemosphere, v. 85, n. 8, p. 1390-1399, 2011.

51. NIKOLAOU, A.; MERIC, S.; FATTA, D. Occurrence patterns of pharmaceuticals in water and wastewater environments. Analytical and Bioanalytical Chemistry, v. 387, n. 4, p. 1225-1234, 2007.

52. GARRIC, J. et al. Effects of the parasiticideivermectin on the cladoceran Daphnia magna and the green alga Pseudokirchneriellasubcapitata.Chemosphere, v. 69, n. 6 , p. 903-910, 2007.

53. ZEILINGER, J. et al. Effects of Synthetic Gestagens on Fish Reproduction. Environmental Toxicology and Chemistry, v. 28, n. 12, p. 2663-2670, 2009.

54. FICK, J. et al. Predicted critical environmental concentrations for 500 pharmaceuticals.Regulatory Toxicology and Pharmacology, v. 58, n. 3, p. 516$523,2010$. 
55. Owen, S.F., Giltrow, E., Huggett, D.B., Hutchinson, T.H., Saye, J., Winter, M.J.,Sumpter, J.P., 2007. Comparative physiology, pharmacology and toxicology ofbeta-blockers: mammals versus fish. Aquat. Toxicol. 82, 145-162.

56. GUNNARSSON, L. et al. Evolutionary conservation of human drug targets in organisms used for environmental risk assessments. Environmental Science \& Technology, v. 42, n. 15, p. 5807-5813, 2008.

57. DESBROW, C. et al. Identification of estrogenic chemicals in STW effluent. 1. Chemical fractionation and in vitro biological screening. Environmental Science \& Technology, v. 32, n. 11, p. 1549-1558, 1998.

58. JOBLING, S. et al. Altered sexual maturation and gamete production in wild roach (Rutilusrutilus) living in rivers that receive treated sewage effluents. Biology of Reproduction, v. 66, n. 2, p. 272-281, 2002.

59. HUGGETT, D. B. et al. Comparison of in vitro and in vivo bioassays for estrogenicity in effluent from North American municipal wastewater facilities. Toxicological Sciences, v. 72, n. 1, p. 77-83, 2003.

60. ANKLEY, G. T. et al. Repeating history: Pharmaceuticals in the environment. Environmental Science \& Technology, v. 41, n. 24, p. 8211-8217, 2007.

61. WINTER, M.J. et al.. Using data from drug discovery and development to aid the aquatic environmental risk assessment of human pharmaceuticals: concepts, considerations, and challenges. Integr. Environ. Assess. Manag. 6, 38-51. 2010

62. TARAZONA, J.V. et al.Targeting the environmental risk assessment of pharmaceuticals: facts and fantasies. Integr. Environ. Assess. Manag. 6, 603-613. 2010

63. EMEA-CPMP, 2005. Guideline on the environmental risk assessment of medicinal products for human use. CPMP/SWP/44447/00 draft. 
64. FDA-CDER, 1998. Guidance for industry-environmental assessment of human drugs and biologics applications. FDA, CDER/CBER, CMC, rev.1.

65. OETKEN, M. et al. Effects of pharmaceuticals on aquatic invertebrates. Part I. The antiepileptic drug carbamazepine. Archives of Environmental Contamination and Toxicology, v. 49, n. 3, p. 353-361, 2005.

66. BROOKS, B. W. et al. Waterborne and sediment toxicity of fluoxetine to select organisms. Chemosphere, v. 52, n. 1, p. 135-142, 2003.

67. HIRSCH, R. et al. Occurrence of antibiotics in the aquatic environment. Science of the Total Environment, v. 225, n. 1-2, p. 109-118, 1999.

68. BATT, A. L.; KOSTICH, M. S.; LAZORCHAK, J. M. Analysis of ecologically relevant pharmaceuticals in wastewater and surface water using selective solidphase extraction and UPLC-MS/MS. Analytical chemistry, v. 80, n. 13, p. 50215030, 2008.

69. KASPRZYK-HORDERN, B.; DINSDALE, R. M.; GUWY, A. J. Multiresidue methods for the analysis of pharmaceuticals, personal care products and illicit drugs in surface water and wastewater by solid-phase extraction and ultra performance liquid chromatography-electrospray tandem mass spectrometry. Analytical and Bioanalytical Chemistry, v. 391, n. 4, p. 1293-1308, 2008.

70. HUERTA-FONTELA, M.; GALCERAN, M. T.; VENTURA, F. Fast liquid chromatography quadrupole-linear ion trap mass spectrometry for the analysis of pharmaceuticals and hormones in water resources.Journal of Chromatography A, v. 1217, n. 25, p. 4212-4222, 2010.

71. MORASCH, B. et al. Occurrence and Fate of Micropollutants in the Vidy Bay of Lake Geneva, Switzerland. Part Ii: Micropollutant Removal between Wastewater and Raw Drinking Water. Environmental Toxicology and Chemistry, v. 29, n. 8, p. 1658-1668, 2010. 
72. HEBERER, T.; FELDMANN, D. Contribution of effluents from hospitals and private households to the total loads of diclofenac and carbamazepine in municipal sewage effluents - Modeling versus measurements (vol 122,pg 211, 2005).Journal of Hazardous Materials, v. 127, n. 1-3, p. 249-249, 2005.

73. CHEFETZ, B.; MUALEM, T.; BEN-ARI, J. Sorption and mobility of pharmaceutical compounds in soil irrigated with reclaimed wastewater.Chemosphere, v. 73, n. 8, p. 1335-1343, 2008.

74. CAVALIERE, Maria J. et al . Miotoxicidade por organofosforados. Rev. Saúde Pública, São Paulo, v. 30, n. 3, June 1996 . Available from $<$ http://www.scielo.br/scielo.php?script=sci_arttext\&pid=S003489101996000300 $010 \& \operatorname{lng}=$ en $\& n r m=$ iso $>$. access

on 10 Aug. 2012. http://dx.doi.org/10.1590/S0034-89101996000300010.

75. DELUCIA, R; OLIEIRA FILHO, R.M. , coord. Farmacologia integrada. 2 ed. Rio de Janeiro. Revinter, 2004. 678 p.

76. KITISRIPANYA, N. et al. Binding of huperzine A and galanthamine to acetylcholinesterase, based on ONIOM method. NanomedicineNanotechnologyBiologyand Medicine, v. 7, n. 1, p. 60-68, 2011.

77. BARTOLUCCI, C. et al. Probing Torpedo californicaAcetylcholinesterase Catalytic Gorge with Two Novel Bis-functional Galanthamine Derivatives. Journal of Medicinal Chemistry, v. 53, n. 2, p. 745-751, 2010.

78. SCHRATTENHOLZ, A. et al. Agonist responses of neuronal nicotinic acetylcholine receptors are potentiated by a novel class of allosterically acting ligands. Molecular Pharmacology, v. 49, n. 1, p. 1-6, 1996.

79. SCHRATTENHOLZ, A. et al. Agonist responses of neuronal nicotinic acetylcholine receptors are potentiated by a novel class of allosterically acting ligands. Molecular Pharmacology, v. 49, n. 1, p. 1-6, 1996. 
80. WILCOCK, G. K. et al. Efficacy and safety of galantamine in patients with mild to moderate Alzheimer's disease: multicentrerandomised controlled trial. British Medical Journal, v. 321, n. 7274, p. 1445-1449, 2000.

81. ZHAO, Q. Y. et al.Galantamine pharmacokinetics, safety, and tolerability profiles are similar in healthy Caucasian and Japanese subjects. Journal of Clinical Pharmacology, v. 42, n. 9, p. 1002-1010, 2002.

82. LAMIRAULT, L. et al. (-)-9-Dehydrogalanthaminium bromide, a new cholinesterase inhibitor, enhances place and object recognition memory in young and old rats. Neurobiology of Learning and Memory, v. 80, n. 2, p. 113-122, 2003.

83. GEERTS, H. et al. Brain levels and acetylcholinesterase inhibition with galantamine and donepezil in rats, mice, and rabbits. BrainResearch, v. 1033, n. 2, p. 186-193, 2005.

84. 86. AL-BADR, A.A., F.G. MUTHADI, IN: K. FLOREY (Ed.). Analytical Profiles of Drug Substances, vol. 14, Academic Press, Orlando, 1985, p. 325.

85. NAMERA, A. et al.Quantitative analysis of tropane alkaloids in biological materials by gas chromatography-mass spectrometry. Forensic Science International, v. 130, n. 1, p. 34-43, 2002.

86. AL-BADR, A.A., F.G. MUTHADI, IN: K. FLOREY (Ed.). Analytical Profiles of Drug Substances, vol. 14, Academic Press, Orlando, 1985, p. 325.

87. SOARES, R. Determinação dos enantiômeros da atropina em soluções oftálmicas empregando a cromatografia líquida de alta eficiência com fase estacionária quiral 195 pp - Dissertação de Mestrado - Universidade de São Paulo. São Paulo, 2007. 
88.KIRCHHOFF, C. et al. Analysis of atropine, its degradation products and related substances of natural origin by means of reversed-phase high-performance liquid chromatography. Journal of Chromatography A, v. 1046, n. 1-2, p. 115-120, 2004.

89. TAHARA, S. et al. Enantiomeric separation of atropine in Scopolia extract and Scopolia Rhizome by capillary electrophoresis using cyclodextrins as chiral selectors. Journal of Chromatography A, v. 848, n. 1-2, p. 465-471, 1999.

90. ZAREH, M. M.; MALINOWSKA, E. Phosphorated calix[6]arene derivatives as an lonophore for atropine-selective membrane electrodes. Journal of Aoac International, v. 90, n. 1, p. 147-152, 2007.

91. PENG, H. et al. Development of a new atropine sulfate bulk acoustic wave sensor based on a molecularly imprinted electrosynthesized copolymer of aniline with o-phenylenediamine. Analytica Chimica Acta, v. 423, n. 2, p. 221-228, 2000.

92. K. Dost and G. Davidson, "Development of a packedcolumnsupercritical fluid chromatography/atmospheric pressurechemical-ionisationmass spectrometric technique for theanalysis of atropine," Journal of Biochemical and Biophysical Methods, vol. 43, no. 1-3, pp. 125-134, 2000.

93. SINGH, S. et al. Aggressive atropinisation and continuous pralidoxime (2PAM) infusion in patients with severe organophosphate poisoning: experience of a northwest Indian hospital. Human \& Experimental Toxicology, v. 20, n. 1, p. 15$18,2001$.

94. KHAN, S. et al.Neuroparalysis and oxime efficacy in organophosphate poisoning: a study of butyrylcholinesterase. Human \& Experimental Toxicology, v. 20, n. 4 , p. $169-174,2001$.

95. BALALI-MOOD, M.; SHARIAT, M. Treatment of organophosphate poisoning.Experience of nerve agents and acute pesticide poisoning on the effects of oximes.JournalofPhysiology-Paris, v. 92, n. 5-6, p. 375-378, 1998. 
96. BUCKLEY, N. A.etal.Oximes for acute organophosphate pesticide poisoning. Cochrane Database of Systematic Reviews, n. 2, 2011.

97. LEE, P.; TAI, D. Y. H. Clinical features of patients with acute organophosphate poisoning requiring intensive care.Intensive Care Medicine, v. 27, n. 4, p. 694699, 2001.

98. HUSAIN, K.; ANSARI, R. A.; FERDER, L. Pharmacological agents in the prophylaxis/treatment of organophosphorous pesticide intoxication.IndianJournalof Experimental Biology, v. 48, n. 7, p. 642-650, 2010.

99. GOSWAMY, R.; CHAUDHURI, A.; MAHASHUR, A. A. Study of Respiratory-Failure in Organophosphate and CarbamatePoisoning.Heart\& Lung, v. 23 , n. 6 , p. 466-472, 1994.

100. THIERMANN, H. et al. Atropine maintenance dosage in patients with severe organophosphate pesticide poisoning. Toxicology Letters, v. 206, n. 1, p. 77-83, 2011.

101. WISHER, D. Martindale: The Complete Drug Reference, 37th edition. Journal of the Medical Library Association, v. 100, n. 1, p. 75-U110, 2012.

102. CHUNG, S. W. C.; CHAN, B. T. P. Validation and use of a fast sample preparation method and liquid chromatography-tandem mass spectrometry in analysis of ultra-trace levels of 98 organophosphorus pesticide and carbamate residues in a total diet study involving diversified food types. Journal of Chromatography A, v. 1217, n. 29, p. 4815-4824, 2010.

103. ANASTASSIADES, M. et al. Fast and easy multiresidue method employing acetonitrile extraction/partitioning and "dispersive solid-phase extraction" for the determination of pesticide residues in produce. JournalofAoacInternational, v. 86, n. 2, p. 412-431, 2003. 
104. QuEChERS-Mini-Multiresidue Method for the Analysis of Pesticides,www.quechers.com.

105. CAZORLA-REYES, R. et al.Single solid phase extraction method for the simultaneous analysis of polar and non-polar pesticides in urine samples by gas chromatography and ultra high pressure liquid chromatography coupled to tandem mass spectrometry. Talanta, v. 85, n. 1, p. 183-196, 2011.

106. CHENG, X. et al. Determination of four kinds of carbamate pesticides by capillary zone electrophoresis with amperometric detection at a polyamidemodified carbon paste electrode. Talanta, v. 71, n. 3, p. 1083-1087, 2007.

107. XAVIER, M. P. et al. Fiber optic monitoring of carbamate pesticides using porous glass with covalently bound chlorophenol red. Biosensors \& Bioelectronics, v. 14, n. 12, p. 895-905, 2000.

108. NI, Y. N.; QIU, P.; KOKOT, S. Simultaneous voltammetric determination of four carbamate pesticides with the use of chemometrics. Analytica Chimica Acta, v. 537, n. 1-2, p. 321-330, 2005.

109. JIN, S. Y. et al. Determination of organophosphate and carbamate pesticides based on enzyme inhibition using a $\mathrm{pH}$-sensitive fluorescence probe. Analytica Chimica Acta, v. 523, n. 1, p. 117-123, 2004.

110. MAGGIO, R. M.; DAMIANI, P. C.; OLIVIERI, A. C. Multivariate curveresolution analysis of pesticides in water samples from liquid chromatographicdiode array data. Talanta, v. 83, n. 4, p. 1173-1180, 2011.

111. CHU, N.; FAN, S. H. Sequential injection kinetic spectrophotometric determination of quaternary mixtures of carbamate pesticides in water and fruit samples using artificial neural networks for multivariate calibration.SpectrochimicaActa Part a-Molecular and Biomolecular Spectroscopy, v. 74, n. 5, p. 1173-1181, 2009. 
112. PACIONI, N. L.; VEGLIA, A. V. Determination of poorly fluorescent carbamate pesticides in water, bendiocarb and promecarb, using cyclodextrinnanocavities and related media.AnalyticaChimicaActa, v. 583, n. 1 , p. 63-71, 2007.

113. MAGGIO, R. M.; DAMIANI, P. C.; OLIVIERI, A. C. Multivariate curveresolution analysis of pesticides in water samples from liquid chromatographicdiode array data. Talanta, v. 83, n. 4, p. 1173-1180, 2011.

114. COMAS, E. et al. Quantification from highly drifted and overlapped chromatographic peaks using second-order calibration methods. Journal of Chromatography A, v. 1035, n. 2, p. 195-202, 2004.

115. FERNANDES, S. C.et al.Methomyl Detection by Inhibition of Laccase Using a Carbon Ceramic Biosensor. Electroanalysis, v. 23, n. 7, p. 1623-1630, 2011.

116. POGAČNIK, L., FRANKO M. Optimisation of FIAsystem for detection of organophosphorus and carbamatepesticidesbased on cholinesterase inhibition. Talanta. Volume 54, Issue 4, 30 May 2001, Pages 631-641

117. BUCUR, B. et al. Biosensors based on highly sensitive acetylcholinesterases for enhanced carbamate insecticides detection. Analytica Chimica Acta, v. 562, n. 1, p. 115-121, 2006.

118. BACHMANN, T. T. et al. Improved multianalyte detection of organophosphates and carbamates with disposable multielectrode biosensors using recombinant mutants of Drosophila acetylcholinesterase and artificial neural networks. Biosensors \& Bioelectronics, v. 15, n. 3-4, p. 193-201, 2000.

119. DU, D. et al. Rapid determination of triazophos using acetylcholinesterase biosensor based on sol-gel interface assembling muldwall carbon nanotubes. Journal of Applied Electrochemistry, v. 37, n. 8, p. 893-898, 2007. 
120. STOYTCHEVA, M. et al. Electrochemical sensor based on Arthrobacterglobiformis for cholinesterase activity determination. Biosensors\&Bioelectronics, v. 22, n. 1, p. 1-9, 2006.

121. AMINE, A. et al. Enzyme inhibition-based biosensors for food safety and environmental monitoring. Biosensors \& Bioelectronics, v. 21, n. 8, p. 1405-1423, 2006.

122. HE, P. et al. Measurement of acetylcholinesterase inhibition using bienzymes immobilized monolith micro-reactor with integrated electrochemical detection. AnalyticaChimicaActa, v. 659, n. 1-2, p. 9-14, 2010.

123. GIRELLI, A. M.; MATTEI, E. Application of immobilized enzyme reactor in on-line high performance liquid chromatography: A review. Journal of Chromatography B-Analytical Technologies in the Biomedical and Life Sciences, v. 819, n. 1, p. 3-16, 2005.

124. URBAN, P. L. et al. On-line low-volume transesterification-based assay for immobilized lipases. JournalofBiotechnology, v. 126, n. 4, p. 508-518, 2006.

125. URBAN, P. L.; GOODALL, D. M.; BRUCE, N. C. Enzymatic microreactors in chemical analysis and kinetic studies. Biotechnology Advances, v. 24, n. 1, p. 42$57,2006$.

126. HE, P. et al. Measurement of acetylcholinesterase inhibition using bienzymes immobilized monolith micro-reactor with integrated electrochemical detection. Analytica Chimica Acta, v. 659, n. 1-2, p. 9-14, 2010.

127. CAMPANELLA, L. et al.A new organic phase enzyme electrode for the analysis of organophosphorus pesticides and carbamates.AnalyticaChimica Acta, v. 385 , n. 1-3, p. 59-71, 1999.

128. GUNTHER, A.; BILITEWSKI, U. Characterization of Inhibitors of Acetylcholinesterase by an Automated Amperometric Flow-Injection System. AnalyticaChimicaActa, v. 300, n. 1-3, p. 117-125, 1995. 
129. KATO, M. et al. Monolithic bioreactor immobilizing trypsin for highthroughput analysis. AnalyticalChemistry, v. 77, n. 6, p. 1813-1818, 2005.

130. KAWAKAMI, K. et al. Development and characterization of a silica monolith immobilized enzyme micro-bioreactor. Industrial \&EngineeringChemistryResearch, v. 44, n. 1, p. 236-240, 2005.

131. ROGERS, K. R. et al.AcetylcholinesteraseFiberoptic Biosensor for Detection of Anticholinesterases. Fundamental andAppliedToxicology, v. 16, n. 4, p. 810-820, 1991.

132. JIN, S. Y. et al. Determination of organophosphate and carbamate pesticides based on enzyme inhibition using a $\mathrm{pH}$-sensitive fluorescence probe. AnalyticaChimicaActa, v. 523, n. 1, p. 117-123, 2004.

133. KUMARAN, S.; MORITA, M. Application of a Cholinesterase Biosensor to Screen for Organophosphorus Pesticides Extracted from Soil. Talanta, v. 42, n. 4, p. 649-655, 1995.

134. NUNES, G. S. et al. Evaluation of a highly sensitive amperometric biosensor with low cholinesterase charge immobilized on a chemically modified carbon paste electrode for trace determination of carbamates in fruit, vegetable and water samples. AnalyticaChimicaActa, v. 399, n. 1-2, p. 37-49, 1999.

135. WU, H. Z. et al.Development of an amperometric micro-biodetector for pesticide monitoring and detection. Journal of the Taiwan Institute of Chemical Engineers, v. 40, n. 2, p. 113-122, 2009.

136. HILDEBRANDT, A.et al.Performance of a portable biosensor for the analysis of organophosphorus and carbamate insecticides in water and food. SensorsandActuators B-Chemical, v. 133, n. 1, p. 195-201, 2008. 
137. ZAPP, E. et al.Biomonitoring of methomyl pesticide by laccase inhibition on sensor containing platinum nanoparticles in ionic liquid phase supported in montmorillonite. SensorsandActuators B-Chemical, v. 155, n. 1, p. 331-339, 2011.

138. WANG, J. et al. Flow injection amperometric detection of OP nerve agents based on an organophosphorus-hydrolase biosensor detector. Biosensors\&Bioelectronics, v. 18, n. 2-3, p. 255-260, 2003.

139. YTU, Y. F.; DI, J. W.; CHEN, X. J. Study of the nano-size silica sol-gel film as the matrix of chemically modified electrode. Journal of Sol-Gel Science and Technology, v. 33, n. 2, p. 187-191, 2005.

151. MARQUES, L. A. et al.Stability-indicating study of the anti-Alzheimer's drug galantamine hydrobromide. Journal of Pharmaceutical and Biomedical Analysis, v. 55, n. 1, p. 85-92, 2011.

152. RIZZI, A. et al. Enantiomeric resolution of galanthamine and related drugs used in anti-Alzheimer therapy by means of capillary zone electrophoresis employing derivatized cyclodextrin selectors. Journal of Chromatography B, v. 730, n. 2, p. 167-175, 1999. 
153. MANNENS, G. S. J. et al. The metabolism and excretion of galantamine in rats, dogs, and humans. Drug Metabolism and Disposition, v. 30, n. 5, p. 553-563, 2002.

154. MALAKOVA, J. et al. High-performance liquid chromatographic method with UV photodiode-array, fluorescence and mass spectrometric detection for simultaneous determination of galantamine and its phase I metabolites in biological samples. Journal of Chromatography B-Analytical Technologies in the Biomedical and Life Sciences, v. 853, n. 1-2, p. 265-274, 2007.

155. GEERTS, H. et al. Brain levels and acetylcholinesterase inhibition with galantamine and donepezil in rats, mice, and rabbits. Brain Research, v. 1033, n. 2, p. 186-193, 2005.

156. CULZONI, M. J.; AUCELIO, R. Q.; ESCANDAR, G. M. Spectrofluorimetry in organized media coupled to second-order multivariate calibration for the determination of galantamine in the presence of uncalibrated interferences. Talanta, v. 82, n. 1, p. 325-332, 2010.

157. WHITE, B. J.; LEGAKO, J. A.; HARMON, H. J. Extended lifetime of reagentless detector for multiple inhibitors of acetylcholinesterase. Biosensors \& Bioelectronics, v. 18, n. 5-6, p. 729-734, 2003.

158.DU, D. et al.Comparison of drug sensitivity using acetylcholinesterase biosensor based on nanoparticles-chitosan sol-gel composite. Journal of Electroanalytical Chemistry, v. 611, n. 1-2, p. 60-66, 2007.

159. OZTURK, G.; ALP, S.; TIMUR, S. A fluorescent biosensor based on acetylcholine sterase and 5-oxazolone derivative immobilized in polyvinylchloride (PVC) matrix. Journal of Molecular Catalysis B-Enzymatic, v. 47, n. 3-4, p. 111116, 2007. 
160. GHOUS, T.; TOWNSHEND, A. Flow injection determination of neostigmine and galanthamine by immobilised acetylcholinesterase inhibition. Analytica Chimica Acta, v. 372, n. 3, p. 379-386, 1998.

161. XU, Z. et al.Monitoring Enzyme Reaction and Screening of Inhibitors of Acetylcholinesterase by Quantitative Matrix-Assisted Laser Desorption/Ionization Fourier Transform Mass Spectrometry. Journal of the American Society for Mass Spectrometry, v. 19, n. 12, p. 1849-1855, 2008.

162. GREENWOOD, P. A. et al. Chemiluminescence mu TAS for the determination of atropine and pethidine. Talanta, v. 56, n. 3, p. 539-545, 2002.

163. SONG, Q. J.; GREENWAY, G. M.; MCCREEDY, T. Tris(2,2 'bipyridine)ruthenium(II) electrogenerated chemiluminescence of alkaloid type drugs with solid phase extraction sample preparation. Analyst, v. 126, n. 1, p. 3740, 2001.

164 BITAR, Y.; HOLZGRABE, U. Impurity profiling of atropine sulfate by microemulsion electrokinetic chromatography. Journal of Pharmaceutical and Biomedical Analysis, v. 44, n. 3, p. 623-633, 2007.

165. HAO, C. et al. Biocompatible conductive architecture of carbon nanofiberdoped chitosan prepared with controllable electrodeposition for cytosensing. Analytical Chemistry, v. 79, n. 12, p. 4442-4447, 2007.

166. HUANG, J. S.; LIU, Y.; YOU, T. Y. Carbon nanofiber based electrochemical biosensors: A review. Analytical Methods, v. 2, n. 3, p. 202-211, 2010.

167. DAR, R. A. et al. Electrochemical determination of atropine at multi-wall carbon nanotube electrode based on the enhancement effect of sodium dodecyl benzene sulfonate.ColloidsandSurfaces B-Biointerfaces, v. 91, p. 10-17, 2012.

168. YANG, X. Y.et al.A Novel Electrochemiluminescence Sensor Based on Tris (2,2 '-bipyridyl)ruthenium(II) Immobilized in Nafion/Electrospun Carbon 
Nanofibers Composite Films. ChineseJournalof AnalyticalChemistry, v. 39, n. 8, p. 1233-1237, 2011.

169. NAKAMURA, M. et al. Uniformly sized molecularly imprinted polymer for atropine and its application to the determination of atropine and scopolamine in pharmaceutical preparations containing scopolia extract. Journal of Pharmaceutical and Biomedical Analysis, v. 37, n. 2, p. 231-237, 2005.

170. SHARMA, R. et al. A quantitative NMR protocol for the simultaneous analysis of atropine and obidoxime in parenteral injection devices. Journal of Pharmaceutical and Biomedical Analysis, v. 49, n. 4, p. 1092-1096, 2009.

171. GUPTA, A. P.; GUPTA, M. M.; KUMAR, S. High performance thin layer chromatography of asiaticoside in Centella asiatica. Journal of the Indian Chemical Society, v. 76, n. 6, p. 321-322, 1999.

172. POHJOLA, J.; HARPF, M. Determination of Atropine and Obidoxime in Automatic Injection Devices Used as Antidotes against Nerve Agent Intoxication. Journal of Chromatography A, v. 686, n. 2, p. 350-354, 1994.

173.CHEN, H. X. et al. Sensitive and specific liquid chromatographic-tandem mass spectrometric assay for atropine and its eleven metabolites in rat urine. Journal of Pharmaceutical and Biomedical Analysis, v. 40, n. 1, p. 142-150, 2006.

174. JOHN, H. et al. LC-ESI MS/MS quantification of atropine and six other antimuscarinic tropane alkaloids in plasma. Analytical and Bioanalytical Chemistry, v. 396, n. 2, p. 751-763, 2010.

175. CHEN, H. X. et al. LC-MS for identification and elucidation of the structure of in-vivo and in-vitro metabolites of atropine. Chromatographia, v. 65, n. 7-8, p. 413-418, 2007.

176. RBEIDA, O. et al. Integrated on-line sample clean-up using cation exchange restricted access sorbent for the LC determination of atropine in human plasma 
coupled to UV detection. Journal of Pharmaceutical and Biomedical Analysis, v. 36, n. 5, p. 947-954, 2005.

177. BOERMANS, P. A. M. M. et al. Quantification by HPLC-MS/MS of atropine in human serum and clinical presentation of six mild-to-moderate intoxicated atropine-adulterated-cocaine users. Therapeutic drug monitoring, v. 28, n. 3, p. 295-298, 2006.

178. . ECKERT, M.; HINDERLING, P. H. Atropine - a Sensitive Gas Chromatography-Mass Spectrometry Assay and Pre-Pharmacokinetic Studies. Agents and Actions, v. 11, n. 5, p. 520-531, 1981.

179. PIHLAJAMAKI, K. et al. Pharmacokinetics of Atropine in Children. International Journal of Clinical Pharmacology and Therapeutics, v. 24, n. 5, p. 236-239, 1986.

180. KENTALA, E.; KAILA, T.; KANTO, J. Intramuscular Atropine in Elderly People - Pharmacokinetic Studies Using the Radioreceptor Assay and Some Pharmacodynamic Responses. Pharmacology \& Toxicology, v. 65, n. 2, p. 110$113,1989$.

181. MIRALDI, E.et al.Distribution of hyoscyamine and scopolamine in Daturastramonium. Fitoterapia, v. 72, n. 6, p. 644-648, 2001.

182. XU, A. et al. Development and validation of an LC/MS/MS method for the determination of L-hyoscyamine in human plasma. JournalofPharmaceuticalandBiomedicalAnalysis, v. 14, n. 1-2, p. 33-42, 1995.

183. 5. JAFFEE, W. B. et al. Ensuring validity in urine drug testing. Psychiatric Services, v. 59, n. 2, p. 140-142, 2008.

184.STEENKAMP, P. A. et al. Fatal Datura poisoning: identification of atropine and scopolamine by high performance liquid chromatography/photodiode 
array/mass spectrometry. Forensic Science International, v. 145, n. 1, p. 31-39, 2004.

185. LAKOWICZ, J.R. Principles of Fluorescence Spectroscopy. Third Edition, 2006.954 pp.

186. SAMANTA, U.; PAL, D.; CHAKRABARTI, P. Environment of tryptophan side chains in proteins. Proteins-Structure Function and Genetics, v. 38, n. 3, p. 288-300, 2000.

187. PERRAUT, C. et al. Role of quaternary structure in muscle creatine kinase stability: Tryptophan 210 is important for dimer cohesion. Proteins-Structure Function and Genetics, v. 32, n. 1, p. 43-51, 1998.

188.SKOGING, U.; LILJESTROM, P. Role of the C-terminal tryptophan residue for the structure-function of the alphavirus capsid protein. Journal of Molecular Biology, v. 279, n. 4, p. 865-872, 1998.

189. 16 .HAREL, M. et al. Crystal structure of an acetylcholinesterase-fasciculin complex: Interaction of a three-fingered toxin from snake venom with its target. Structure, v. 3, n. 12, p. 1355-1366, 1995.

190. 17 .KATZ, B. A. Binding to Protein Targets of Peptidic Leads Discovered by Phage Display - Crystal-Structures of Streptavidin-Bound Linear and Cyclic Peptide Ligands Containing the Hpq Sequence. Biochemistry, v. 34, n. 47, p. 15421-15429, 1995.

191. YENGO, C. M.et al.Smooth muscle myosin mutants containing a single tryptophan reveal molecular interactions at the actin-binding interface. Proceedings of the National Academy of Sciences of the United States of America, v. 95, n. 22, p. 12944-12949, 1998. 
192.LANDOLTMARTICORENA, C. et al. Nonrandom Distribution of AminoAcids in the Transmembrane Segments of Human Type-I Single Span MembraneProteins. Journal of Molecular Biology, v. 229, n. 3, p. 602-608, 1993.

193. DOYLE, D. A.; WALLACE, B. A. Crystal structure of the gramicidin/potassium thiocyanate complex. Journal of Molecular Biology, v. 266, n. 5, p. 963-977, 1997.

194. HU, W.; CROSS, T. A. Tryptophan Hydrogen-Bonding and Electric-Dipole Moments - Functional Roles in the Gramicidin Channel and Implications for Membrane-Proteins. Biochemistry, v. 34, n. 43, p. 14147-14155, 1995.

196. D’AURIA, S; LAKOWICZ, J.R.Enzyme fluorescence as a sensing tool: new perspectives in biotechnology. Curr. Opin Biotechnol. 2001 Feb;12(1):99-104.

197. JIN, T. et al. Antibody-protein A conjugated quantum dots for multiplexed imaging of surface receptors in living cells.Mol Biosyst. Nov;6(11):2325-31. 2010

198. TAYLOR, J. L. et al. Conformers of Acetylcholinesterase: A Mechanism of AllostericControl. Molecular Pharmacology, 45:74-83. 1993.

199.MICHEL, H. O.; KROP, S. The Reaction of Cholinesterase with Diisopropyl Fluorophosphate. Journal of Biological Chemistry, v. 190, n. 1, p. 119-125, 1951.

200.PERRIER, N. A. et al. Readthrough acetylcholinesterase expression remains minor after stress or exposure to inhibitors. Journal of Molecular Neuroscience, v. 30, n. 1-2, p. 75-76, 2006.

201. KOVARIK, Z. et al. Exploring the active sites of cholinesterases by inhibition with bambuterol and haloxon. Croatica Chemica Acta, v. 76, n. 1, p. 63-67, 2003.

202. CHATONNET, A.; LOCKRIDGE, O. Comparison of butyrylcholinesterase andacetylcholinesterase. The Biochemical Journal, Londres, v.260, n.3, p.625634,1989 . 
203. MORALEV S. N., ROZENGART, E. V.Comparative Enzymology of Cholinesterases., International University Line 484 p, 2006.

204. ZHOU, X. ET AL. Design, synthesis, and acetylcholinesteraseinhibitory activity of novelcoumarin analogues.Bioorganic\& Medicinal Chemistry 16, 8011802, 2008.

205. ORDENTLICH, A. ET AL. Dissectin of the human acetylcholinesterase active center determinants of substrate specificity. Identification of residue constituting of anionic site, the hydrophobic site, and the acyl pocket. Jounal biology Chemistru, 1993, 268:17083-17095.

206. DURAN ET AL. Effect of fasciculin on hydrolysis of neutral and choline esters by butytylcholinesterase, cobra venom and chikenacetylcholinesterase. Toxicom. 15009-15108.1996.

207. DIAZ, A. N.;PEINADO. M.C. R..Sol-gel cholinesterase biosensor for organophosphonus pesticide fluorimetric analysis. Sensors and Actuators B 38-39 (1997) 426-431

208. PEINADO, M.C.R. Sol-gel cholinesterase biosensor for organophosphonus pesticide fluorimetric analysis Sensors and Actuators B: Chemical.Volume 39, Issues 1-3. 426-431 pp.. 1997

209. ESTRADA-MONDACA, S., LOUGARRE, A., FOURNIER, D. Drosophilaacetylcholinesterase: effect of post-translational modifications onthe production in the baculovirus system and substrate metabolization.Archives of Insect Biochemistry and Physiology 38, 84_/90. 1998

210.VILLATTE, F., BACHMANN, T.T., HUSSEIN, A.S., SCHMID, R.D.,.Acetylcholinesterase assay for rapid expression screening in liquidand solid media. Biotechniques 30 (81_/84), 86.2001 
211. RALSTON, J.S., et al. Useof procainamide gels in the purification of human and horse serumcholinesterase. Biochemical Journal 211, 243_/250. 1983

212.HUSSEIN, A.S., et al. Determinants of substrate specificity of a second nonneuronalsecreted acetylcholinesterase from the parasitic nematode Nippostrongylusbrasiliensis . European Journal of Biochemistry 267,2276_2282. 2000

213. SZEGLETES, T. et al.Substrate binding to the peripheral site of acetylcholinesterase initiates enzymatic catalysis. Substrate inhibition arises as a secondary effect. Biochemistry, v. 38, n. 1, p. 122-133, 1999.

214. TARA, S. et al. Rapid binding of a cationic active site inhibitor to wild type and mutant mouse acetylcholinesterase: Brownian dynamics simulation including diffusion in the active site gorge. Biopolymers, v. 46, n. 7, p. 465-474, 1998.

215. MALLENDER, W. D.; SZEGLETES, T.; ROSENBERRY, T. L. Acetylthiocholine binds to asp74 at the peripheral site of human acetylcholinesterase as the first step in the catalytic pathway. Biochemistry, v. 39, n. 26, p. 7753-7763, 2000.

216. CHANGEUX, J. P. Responses of Acetylcholinesterase from Torpedo Marmorata to Salts and Curarizing Drugs. Molecular Pharmacology, v. 2, n. 5, p. 369-\&, 1966.

217. HUCHO, F.; JARV, J.; WEISE, C. Substrate-Binding Sites in Acetylcholinesterase. Trends in Pharmacological Sciences, v. 12, n. 11, p. $422-$ 426, 1991.

218. BARAK, D. et al. Allosteric Modulation of Acetylcholinesterase Activity by Peripheral Ligands Involves a Conformational Transition of the Anionic Subsite. Biochemistry, v. 34, n. 47, p. 15444-15452, 1995. 
219. HAREL, M. et al. Quaternary Ligand-Binding to Aromatic Residues in the Active-Site Gorge of Acetylcholinesterase. Proceedings of the National Academy of Sciences of the United States of America, v. 90, n. 19, p. 9031-9035, 1993.

220. HAREL, M. et al. The X-ray structure of a transition state analog complex reveals the molecular origins of the catalytic power and substrate specificity of acetylcholinesterase. Journalofthe American ChemicalSociety, v. 118, n. 10, p. 2340-2346, 1996.

221. BERMAN, H. A.; BECKTEL, W.; TAYLOR, P. Spectroscopic Studies on Acetylcholinesterase - Influence of Peripheral-Site Occupation on Active-Center Conformation. Biochemistry, v. 20, n. 16, p. 4803-4810, 1981.

222. BIGBEE, J. W. et al. Morphogenic role for acetylcholinesterase in axonal outgrowth during neural development. Environmental Health Perspectives, v. 107, p. 81-87, 1999.

223. BOURNE, Y. et al. Structural insights into ligand interactions at the acetylcholinesterase peripheral anionic site. Embo Journal, v. 22, n. 1, p. 1-12, 2003.

224. BOURNE, Y. et al. Substrate and product trafficking through the active center gorge of acetylcholinesterase analyzed by crystallography and equilibrium binding. Journal of Biological Chemistry, v. 281, n. 39, p. 29256-29267, 2006.

225. DINAMARCA, M. C. et al.Amyloid-beta-Acetylcholinesterase complexes potentiate neurodegenerative changes induced by the A beta peptide. Implications for the pathogenesis of Alzheimer's disease. Molecular Neurodegeneration, v. 5, 2010.

226. DE FERRARI, G. V. et al.Thioflavin T is a fluorescent probe of the acetylcholinesterase peripheral site that reveals conformational interactions between the peripheral and acylation sites. Journal of Biological Chemistry, v. 276, n. 26, p. 23282-23287, 2001. 
227. STSIAPURA, V. I. et al.Computational study of thioflavin $\mathrm{T}$ torsional relaxation in the excited state. Journal of Physical Chemistry A, v. 111, n. 22, p. 4829-4835, 2007.

228. SULTATOS, L. G.; KAUSHIK, R. Altered binding of thioflavin th the peripheral anionic site of acetylcholinesterase after phosphorylation of the active site by chlorpyrifosoxon or dichlorvos. Toxicology and Applied Pharmacology, v. 230, n. 3, p. 390-396, 2008.

229. NAIK, L. R.; NAIK, A. B.; PAL, H. Steady-state and time-resolved emission studies of Thioflavin-T. Journal of Photochemistry and Photobiology aChemistry, v. 204, n. 2-3, p. 161-167, 2009.

230. KUMAR, S. et al.Thioflavin T Displays Enhanced Fluorescence Selectively Inside Anionic Micelles and Mammalian Cells. Journal of Fluorescence, v. 18, n. 6, p. 1199-1205, 2008.

231. JOHNSON, J. L. et al. Unmasking tandem site interaction in human acetylcholinesterase. Substrate activation with a cationic acetanilide substrate.Biochemistry, v. 42, n. 18, p. 5438-5452, 2003.

232. TAYLOR, P.; LAPPI, S. Interaction of Fluorescence Probes with Acetylcholinesterase - Site and Specificity of Propidium Binding. Biochemistry, v. 14, n. 9, p. 1989-1997, 1975.

233. BERMAN, H. A. et al. Site Selectivity of Fluorescent BisquaternaryPhenanthridinium Ligands for Acetylcholinesterase. Molecular Pharmacology, v. 31, n. 6, p. 610-616, 1987.

234. SUSSMAN, J. L. et al. Atomic-Structure of Acetylcholinesterase from Torpedo-Californica - a Prototypic Acetylcholine-Binding Protein. Science, v. 253, n. 5022, p. 872-879, 1991. 
235. HAREL, M. et al. Crystal structure of thioflavin T bound to the peripheral site of Torpedo californicaacetylcholinesterase reveals how thioflavin $\mathrm{T}$ acts as a sensitive fluorescent reporter of ligand binding to the acylation site. Journal of the American Chemical Society, v. 130, n. 25, p. 7856-7861, 2008.

236. ELLMAN, G.L. et al. A new and rapid colorimetric determination of acetilcholinesterase activity. Biochemical Pharmacology. vol. 7, p. 88-95, 1961.

237. PETTERSON, G. L. A simplification of the protein assay method of lowry et al. which is more generally applicable. Anal. Biochem. 83, 346-356. 1977

238. TAYLOR,P.Electrostatic Influence on the Kinetics of Ligand Binding to Acetylcholinesterase : Distinctions between active center ligands and fasciculin. The Journal of Biological Chemistry, 272, 23265-23277. September 12, 1997

239. WILLE, T.; THIERMANN, H.; WOREK, F. Effect of different buffers on kinetic properties of human acetylcholinesterase and the interaction with organophosphates and oximes. Archives of Toxicology, v. 85, n. 3, p. 193-198, 2011.

240. MENDES, A.M.;RICCI, M. S.F. Amostragem de solos para análise química. Porto Velho: EMBRAPA-CPAF Rondônia, 1997.11p. (EMBRAPACPAF Rondônia. Circular Técnica, 33).

241. GALVANI,F.; FERNANDES,F.A. Registro e preparação de amostras de solo para análise física e químicas. EMBRAPA, ago. 2005. (EMBRAPA. Circular técnica).

242. VIANNA, M.S. Pesticidas em solos agrícolas de Nova Friburgo (R.J.): aplicação da metodologia enzimática de inibição da AChE e estudos da influência dos parâmetros de fertilidade do solo - Dissertação de Mestrado. Pontifícia Universidade Católica (PUC-RIO). 2008. 
243. INMETRO, DOQ - CGCRE - 008. Orientação sobre validação de métodos de ensaios químicos, rev. 02, junho/2007.

244. ROSENBERRY, T.L. Advances in Enzymology and Related Areas of Molecular Biology: Acetylcholinesterase. Wiley, 2006. Vol 61

245. ALBERTS, P.; BARTFAI, T. Muscarinic Acetylcholine-Receptor from RatBrain - Partial-Purification and Characterization. Journal of Biological Chemistry, v. 251, n. 6, p. 1543-1547, 1976.

246. I, M. et al. Quantifying receptor properties: the tissue segment binding method - a powerful tool for the pharmacome analysis of native receptors. Journal of Pharmacological Sciences, v. 98, n. 4, p. 331-339, 2005.

247. LARSON, E. W.; PFENNING, M. A.; RICHELSON, E. Selectivity of Antimuscarinic Compounds for Muscarinic Receptors of Human Brain and Heart. Psychopharmacology, v. 103, n. 2, p. 162-165, 1991.

248. KLOOG, Y.; SOKOLOVSKY, M. Studies on Muscarinic Acetylcholine Receptors from Mouse-Brain - Characterization of the Interaction with Antagonists. Israel Journal of Medical Sciences, v. 15, n. 1, p. 92-92, 1979.

249. DELIMA, J. S. et al.Methyl parathion activation by a partially purified rat brain fraction. Toxicology Letters, v. 87, n. 1, p. 53-60, 1996.

250. ADAMSON, E.D. et al. Analysis of the Forms of Acetylcholinesterase from Adult Mouse Brain - Biochemistry- 147(2):205-14 . 1975

251. ORLOV, N. Y. et al. Comparative study of recombinant rat nucleoside diphosphate kinases alpha and beta by intrinsic protein fluorescence. Journal of Biomolecular Structure \& Dynamics, v. 16, n. 4, p. 955-968, 1999.

252. BRUNS, R.E. et. al. COMO FAZER EXPERIMENTOS: Pesquisa e desenvolvimento na ciência e na indústria. Editora Unicamp, 2007. 480 pp. 
253.TEOFILO, Reinaldo F.; FERREIRA, Márcia M. C.. Quimiometria II: planilhas eletrônicas para cálculos de planejamentos experimentais, um tutorial. Quím. Nova, São Paulo, v. 29, n. 2, Apr. 2006 . Available from $<$ http://www.scielo.br/scielo.php?script=sci_arttext\&pid=S010040422006000200 026\&lng=en\&nrm=iso $>$. access on 10 Aug. 2012. http://dx.doi.org/10.1590/S0100-40422006000200026

254. SABINO, B. D. et al. Development of a Simple and Low-Cost Enzymatic Methodology for Quantitative Analysis of Carbamates in Meat Samples of Forensic Interest. Journal of Forensic Sciences, v. 55, n. 3, p. 808-812, 2010.

255. FARIA, M.V.C.F. Avaliação de ambientes e produtos contaminados por agrotóxicos In: Livro é Veneno ou Remédio: agrotóxicos, saúde e e ambiente. Frederico Peres e Josino Costa Moreira (Orgs.). Rio de Janeiro. Editora FIOCRUZ,. 2003, 384 pp.

256. BORISSEVITCH, I. E. More about the inner filter effect: corrections of SternVolmer fluorescence quenching constants are necessary at very low optical absorption of the quencher. Journal of Luminescence, v. 81, n. 3, p. 219-224, 1999.

257. TIAN, J. Fluorescence Studies on the Interactions of Barbaloin with Bovine Serum Albumin. Chem. Pharm. Bull. 51(5) 579—582 (2003)

258. KATO, G.; YUNG, J.; IHNAT, M. Nmr Studies of Interaction of Eserine and Atropine with Acetylcholinesterase. Biochemical and Biophysical Research Communications, v. 40, n. 1, p. 15-\&, 1970.

259. KATO, G.; TAN, E.; YUNG, J. Acetylcholinesterase - Kinetic Studies on Mechanism of Atropine Inhibition. Journal of Biological Chemistry, v. 247, n. 10, p. 3186-\&, 1972. 
260. XU, H. et al. Spectroscopic Studies on the Interaction of Vitamin C with Bovine Serum Albumin. Journal of Solution Chemistry, v. 38, n. 1, p. 15-25, 2009.

261. LIU, X. et al. Effect of Hydrogenation on Ring C of Flavonols on Their Affinity for Bovine Serum Albumin. Journal of Solution Chemistry, v. 39, n. 4, p. 533-542, 2010.

262. WANG, Z. M. et al. Study on the Binding Behavior of Lysozyme with Cephalosporin Analogues by Fluorescence Spectroscopy. Journal of Fluorescence, v. 19, n. 5, p. 801-808, 2009.

263. LISSI, E.; ABUIN, E. On the Evaluation of the Number of Binding Sites in Proteins From Steady State Fluorescence Measurements. Journal of Fluorescence, v. 21, n. 5, p. 1831-1833, 2011.

264. MAELICKE, A. et al. Allosteric sensitization of nicotinic receptors by galantamine, a new treatment strategy for Alzheimer's disease. Biological Psychiatry, v. 49, n. 3, p. 279-288, 2001.

265. MAELICKE, A. et al. Allosterically potentiating ligands of nicotinic receptors as a treatment strategy for Alzheimer's disease. Behavioural Brain Research, v. 113, n. 1-2, p. 199-206, 2000.

266. BARTOLUCCI, C. et al. Three-dimensional structure of a complex of galanthamine (Nivalin (R)) with acetylcholinesterase from Torpedo californica: Implications for the design of new anti-Alzheimer drugs. Proteins-Structure Function and Genetics, v. 42, n. 2, p. 182-191, 2001.

267. RAVES, M. L. et al. Structure of acetylcholinesterase complexed with the nootropic alkaloid, (-)-huperzine A. Nature Structural Biology, v. 4, n. 1, p. 5763, 1997. 
268. SAMOCHOCKI, M. et al. Galantamine is an allosterically potentiating ligand of neuronal nicotinic but not of muscarinic acetylcholine receptors. Journal of Pharmacology and Experimental Therapeutics, v. 305, n. 3, p. 1024-1036, 2003.

269. ALBUQUERQUE, E. X. et al. Mammalian Nicotinic Acetylcholine Receptors: From Structure to Function. Physiological Reviews, v. 89, n. 1, p. 73 $120,2009$.

270. HANSEN, S. B. et al. Tryptophan fluorescence reveals conformational changes in the acetylcholine binding protein. Journal of Biological Chemistry, v. 277, n. 44, p. 41299-41302, 2002.

271. TREVITT, C.R. et al. Enhanced Ligand Affinity for Receptorsin which Components of the Binding SiteAre Independently Mobile - Chemistry \& Biology, Vol. 12, 89-97, January, 2005,

272. GREENBLATT, H.M. Structure of acetylcholinesterase complexed with (3)galanthamine at2.3 Aî resolution. FEBS Letters 463 321^326 - 1999.

273. 278. SINGH, A. K.; SPASSOVA, D. Effects of hexamethonium, phenothiazines, propranolol and ephedrine on acetylcholinesterase carbamylation by physostigmine, aldicarb and carbaryl: Interaction between the active site and the functionally distinct peripheral sites in acetylcholinesterase. Comparative Biochemistry and Physiology C-Pharmacology Toxicology \& Endocrinology, v. 119, n. 1, p. 97-105, 1998.

274. HANSEN, S. B.; TAYLOR, P. Galanthamine and non-competitive inhibitor binding to ACh-binding protein: Evidence for a binding site on non-alpha-subunit interfaces of heteromeric neuronal nicotinic receptors. Journal of Molecular Biology, v. 369, n. 4, p. 895-901, 2007.

275. FUKUTO, T. R. Mechanism of Action of Organophosphorus and Carbamate Insecticides. Environmental Health Perspectives, v. 87, p. 245-254, 1990. 
276.WINTERIN.FP; FOWLER, K. S. Substrate and Dilution Effects on Inhibition of Acetylcholinesterase by Carbamates. Biochemical Journal, v. 101, n. 1, p. 127$\&, 1966$.

277. HASTINGS, F. L.; MAIN, A. R.; IVERSON, F. Carbamylation and Affinity Constants of Some Carbamate Inhibitors Ofacetylcholinesterase and Their Relation to Analogous Substrate Constants. Journal of Agricultural and Food Chemistry, v. 18, n. 3, p. 497-\&, 1970.

278. SINGH, A. K.; SPASSOVA, D. Effects of hexamethonium, phenothiazines, propranolol and ephedrine on acetylcholinesterase carbamylation by physostigmine, aldicarb and carbaryl: Interaction between the active site and the functionally distinct peripheral sites in acetylcholinesterase. Comparative Biochemistry and Physiology C-Pharmacology Toxicology \& Endocrinology, v. 119, n. 1, p. 97-105, 1998.

279. DELIMA, J. S. et al.Methyl parathion activation by a partially purified rat brain fraction. Toxicology Letters, v. 87, n. 1, p. 53-60, 1996.

280. MASKEVICH, A. A. et al. Spectral properties of thioflavin t in solvents with different dielectric properties and in a fibril-incorporated form. Journal of Proteome Research, v. 6, n. 4, p. 1392-1401, 2007.

281.ROSENBERRY, R.L. Monitoring the reaction of carbachol with acetylcholinesterase by thioflavin $\mathrm{T}$ fluorescence and acetylthiocholine hydrolysis - Chemico-Biological Interactions 175 235-241, 2008.

282. WILDMAN, S. Drug-like Leads for Steric Discriminationbetween Substrate and Inhibitors of HumanAcetylcholinesterase - Chem Biol Drug Des; 78: 495504,2011

283. HUDSON, S. A. et al. The thioflavin T fluorescence assay for amyloid fibril detection can be biased by the presence of exogenous compounds. Febs Journal, v. 276, n. 20, p. 5960-5972, 2009. 
284. SEN, P. et al. Interactions of thioflavin T with serum albumins: Spectroscopic analyses. Spectrochimica Acta Part a-Molecular and Biomolecular Spectroscopy, v. 74, n. 1, p. 94-99, 2009.

285. NAIK, L. R.; NAIK, A. B.; PAL, H. Steady-state and time-resolved emission studies of Thioflavin-T. Journal of Photochemistry and Photobiology aChemistry, v. 204, n. 2-3, p. 161-167, 2009.

286. ZHANG, H. et al. Affinity Binding-Guided Fluorescent Nanobiosensor for Acetylcholinesterase Inhibitors via Distance Modulation between the Fluorophore and Metallic Nanoparticle . Anal. Chem. 84, 2830-2836 - 2012

287. VETKIN D. O.,Study of Cholinesterase Active Site Using a Fluorescent Probe

- Biology Bulletin, Vol. 31, No. 2, pp. 121-125, 2004

288. ZHAO, W. Selective Detection of Hypertoxic Organophosphates Pesticides via PDMS Composite based Acetylcholinesterase-Inhibition Biosensor - Environ. Sci. Technol., 43, 6724-6729, 2009

289.GAUTHIE, T.D. et al.Fluorescence Quenching Method for Determining Equilibrium Constants forPolycyclic Aromatic Hydrocarbons Binding to Dissolved Humic Materials. Environ. Sci. Technol. 20, 1162-1 166 - 1986 